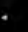




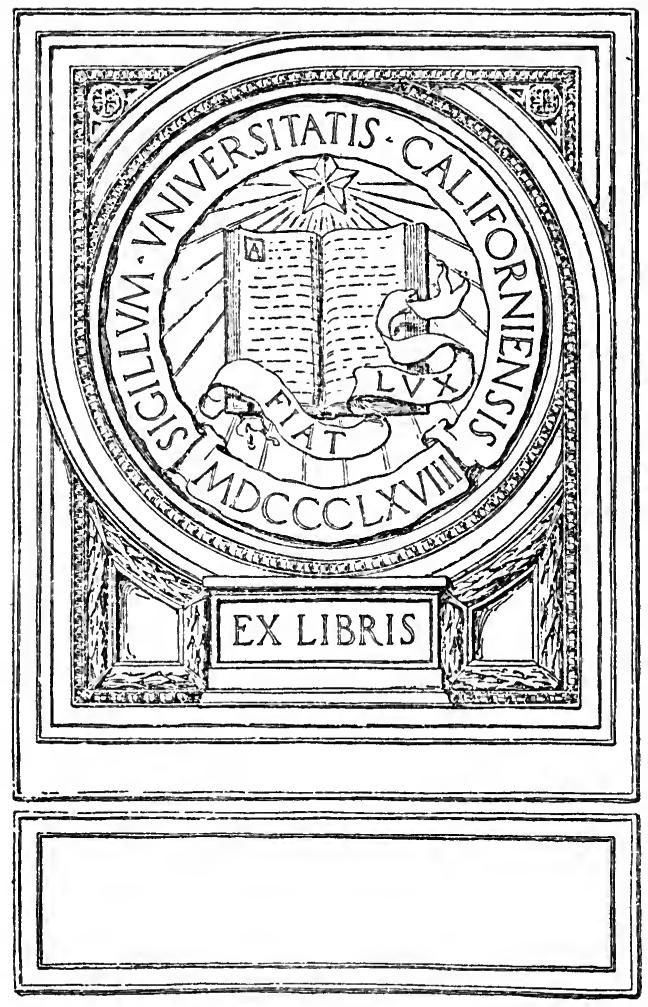



Digitized by the Internet Archive in 2007 with funding from Microsoft Corporation 


\section{THE PROBLEM of WAR AND ITS SOLUTION}


. 


\section{The PROBLEM of WAR AND ITS SOLUTION By JOHN E. GRANT}

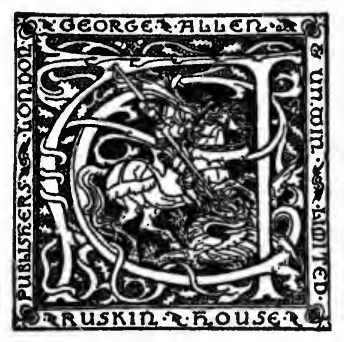

LONDON: GEORGE ALLEN \& UNWIN LTD. RUSKIN HOUSE, $4 \circ$ MUSEUM STREET, W.C. I 


\section{HB195 G)}

First published in 1922

(All rights reserved) 
TO

\section{THE CHILDREN}

$$
498306
$$





\section{PREFACE}

A PREFACE is frequently in the nature of an apology made, either by some publicist to his circle of readers in introducing a new or little-known writer, or by the author himself for temerity in obtruding his views upon some threadbare theme. I offer no excuses for what may appear to be rashness on my part, because, although very many books have been written about war and wars, there are few indeed in which human warfare is regarded as a problem capable of solution, and scarcely any having for their purpose its elucidation. The reason is that war is generally believed to be inherent in human nature and that there is therefore no solution.

The intention behind these pages is to demolish this fatalistic doctrine and to substitute a reasonable theory more in accordance with the facts. As might be expected, once the real factors of the problem are known the solution is at hand for those who are not dismayed by the bogies of tradition.

At this time when all earnest men are looking for a stable foundation upon which the edifice of a durable peace may be erected, my hope is that this book will usefully contribute towards the attainment of their desires. Criticism, hostile or otherwise, is welcome, because honest discussion speeds the day when there shall be peace on earth and goodwill towards men.

J. E. G.

SURBITON,

December I92I. 



\section{CONTENTS}

\section{INTRODUCTION}

\section{BOOK I}

\section{THE BIOLOGICAL ASPECT}

II. Heredity, Environment, AND the Race

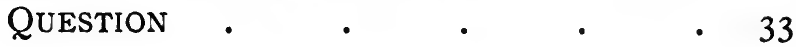

III. The Principle of Population $\quad$ - 53

IV. The Alleged Cruelty of Nature, the STRUGGLE FOR EXISTENCE, AND THE LAW of Battle.

V. Rudimentary WaR $\quad$ • $\quad$ • $\quad$ • 95

VI. Rudimentary Human War • • • 107

VII. EQUALITY OF OPPORTUNITY • • • $\quad$ II9

BOOK II

\section{THE HISTORICAL ASPECT}

VIII. The ORIgIN OF the PRofiteer 
CHAPTER PAGE

X. The Instability of Principalities and POWERS - $\mathrm{I} 73$

XI. NOT BY POWER, NOR BY MIGHT • . I9I

/ XII. The Secret of History • • • 205

XIII. The Captivity of Ignorance • 23 I

XIV. The Slavery of Monopolies • • 255

BOOK III

\section{FROM THE OLD TO THE NEW WORLD}

XV. Usury and the Great Bubble • . 279

XVI. The Psychology of Captivity • • 303

XVII. The Rule of the Land • • • 333

XVIII. PRACTICAL POLITICS V. IMPRACTICAL

POLITICS 


\section{Parallels from Henry Grattan's Speeches}

(Time of the Napoleonic Struggle)

\section{THE "FREEDOM" OF THE SEAS.}

" England has checked his designs ; her trident has stirred up his Empire from its foundations : he complained of her tyranny at sea; but it was her power at sea which arrested his tyranny on land-the Navy of England saved Europe."

\section{THE MAD DOG OF EUROPE.}

"He who said, "I will be like the Most High'; he who smote the nations with a continual stroke-this short-lived son of the morning, Lucifer, falls, and the earth is at rest."

\section{THE PERILS OF PEACE.}

"Such offers of peace are nothing more than one of the arts of war, attended most assuredly by charging on you the odium of a long and protracted contest, and with much commonplace and many good saws and sayings of the miseries of bloodshed and the savings and good husbandry of peace.... But if you listen to this you will be much deceived ... not only deceived, but you will be beaten."

"Suppose you treat for peace, you will have a peace upon a war establishment, and then a war without your present Allies."

\section{A WAR FOR LIBERTY, GIVILISATION AND CHRISTIANITY} AGAINST FRENGH MILITARISM.

" Do you wish to confine this military tyranny in the heart of Europe ? A tyranny founded on the triumph of the Army over the principles of civil government, tending to universalise throughout Europe the domination of the sword, and to reduce to paper and parchment Magna Gharta and all our civil institutions . . . an experiment to set Heaven and Earth adrift from one another, and make God Almighty a tolerated alien in His own Creation."

\section{A WAR TO END WAR.}

"You must not consider the money you spend in your defence, but the fortune you would lose if you were not defended-further, recollect you will pay less to an immediate war than to a peace with a war establishment, and a war to follow-recollect further, that whatever be your resources, they must outlast those of all your enemies." 



\section{INTRODUCTION}

\section{CHAPTER I}

\section{THE FALLAGY OF FATALISM}

\section{READER'S GUIDE}

Chapter I treats of the current beliefs with regard to war and civil commotion. It is an introductory chapter.

\section{The Headings are:}

The National Discords-International Discords-The Militant Evolutionists-Governments and War-The High Moral Feeling upon Entry into War-What is meant by Militarism-Fighting for Freedom-A Durable Peace -Fatalism is Opposed to Common Sense-The Problem. 
I know that I am among men, because they are fighting; I know that I am among civilised men, because they are fighting so savagely.-VoltaIRE. 
CHAPTER I

\section{THE FALLAGY OF FATALISM}

\section{The National Discords.}

Long before the Great War broke out, a growing spirit of fatalism could be traced in the thought pervading the newspapers, literature and conversation of the day. All strife, including that of bloodshed, was definitely regarded to be inevitable. War was said to be based upon human nature. It was believed that the most that could be hoped for was the lessening of its effects when it occurred by measures of charity like the Hague Conventions, much as the Churches endeavour to gloss over the social crime of poverty by organised benevolence.

Industrial strikes and lock-outs, religious and party conflicts were alike considered unavoidable, and it was believed that the disputants could only be prevented from resorting to extremes by the wholesome fear of man-made laws or ordinances, backed by the greater violence of Government, represented by the police and the military. Society apparently owed its existence to, and was held together by, what may be described as a manifestation of organised coercion.

Legislation was the result of compromise; hence the Statute Book was bulky with enactments intended for the regulation of a complex, self-willed society. A civil army of bureaucratic officials assisted Rank, Caste and Privilege in their administration, but in spite of all this, outbreaks of individuals, or combinations of individuals, were continually taking place. These Government seemed powerless to prevent, and indeed was powerless. It was especially noticeable that unions of what was loosely called Labour had interminable wars with federations of what was as loosely termed Capital. Hopeful schemes of Parliament for the purpose of balancing these powerful interests were 
continually put iorward, but whether made operative after bitter contention or turned down, the result was invariably disappointing for both sides.

Labour blamed predatory Capital, Capital discussed the ingratitude of Labour, what time optimistic politicians, assisted by their partisan Press, tried vainly to prove benefits where none existed, unless the establishment of an increased number of self-satisfied bureaucrats, burdening industry, could be said to be a benefit to anyone. The infinite good intent of statesmen seemed capable of exhausting the eternal springs of hope!

By many the Government was accused of impotence, and it is worthy of remark that while physical violence was not withheld in dealing with a few outlaws in the East End of London and the militant suffragettes, the gunrunning of Ulster was successfully accomplished without interference under the able leadership of an important legal ornament and Member of Parliament.

In Ireland and elsewhere there were many who thought that self-government would be a cure for this and other ills, but there were others who felt that present discomforts were better borne than the application of a medicine beneficial to the one part, while it deranged another even temporarily. In any case, could the conditions obtaining in England afford any hope that Ireland with Home Rule would avoid the discords destroying the harmony in the former country? In other European countries or in America, it could not be said without bias that their Governments were achieving any greater measure of success.

It was fashionable to think that more governmental power was necessary to keep in order the rebellious people. To make the world really fit for habitation, the natural passions, prejudices and hatreds of human beings must be severely repressed, or how otherwise was it possible to expect the people to do what was right? Without the barbarous penal code, administered with disciplinary firmness, it was considered, not without reason, that the people would insurge instantly.

Individuals even of different and remote nationalities composing the manufacturing and trading community might observe certain principles to their mutual advantage 
in dealing with each other, and did regard the cumbrous legal processes of their respective countries of less than no effect, compared with the impulsion of mutual satisfaction. But no lesson was drawn from this. It was thought by the "ruling" classes that the "lower" orders had no self-respect, and the latter thought that the cause of their oppression lay in the overweening ambition of the "powerful." Each side sought to control the other by means of legislation, and thousands of mutually destructive "laws," amendments and consolidations were instituted, adding to the confusion. Things went from bad to worse.

With every fresh addition to the Statute Book, new crimes brought forth new criminals into society, which only heightened the belief encouraged by the Churches, that the Sermon on the Mount teaching was visionary and even impracticable, because man is born in sin and conceived in wickedness. "The natural man must be crucified," said present-day Pharisees, "if we are to have a healthy community."

That the community was not in a state of health was only too apparent, when the symptoms were noted. At one time there would be the hectic glow of feverish activity, to be followed inevitably by a period of depression and stupor, in which the fatalistic drugged themselves in Fabianism, Nietzschean philosophy, Rubáiyáts and necromancy.

Forlorn attempts were made from time to time by the unrestful to find a way out of the tangle into which society found itself. There was an undercurrent of enlightenment moving towards the removal of certain fundamental errors upon which the tangle had developed, but these efforts were met with flippant and almost instinctive dislike. They were side-tracked by the law-makers, screened-off by the newspaper press, or shouted down by loud Party cries above the wars of the factions.

The air was full of fear, and there was a tendency to paralytic drift on the part of statesmen, or movement in a direction of greater severity in government. In pursuance of this gravitation towards forceful methods, there were two converging tendencies, one of which was the oligarchical tyranny of a few ephors, and the other that of many, 
which may be described as State-Socialism. It was in Germany where most progress had been made in this respect under the welding influence of that barefaced despot Kaiser Wilhelm II.

\section{International Discords.}

In international affairs, interests rather than principles, even more than in national affairs, guided the policies of the Governments in their dealings with each other. Above and beyond national discords, which existed in every country, there also rumbled international discordance, which manifested itself in territorial and commercial jealousies, associated with rivalries for the possession of the "White Man's Burden."

The origins were obscure and little understood, but many saw in racial hatreds, differences in language or national character sufficient cause for "natural" animosities. But whatever might be the origins, there was a feeling that war was inevitable sooner or later. It was the duty therefore of those in charge of the destinies of each nation to make preparation, since a strong nation armed was least likely to be attacked.

Curiously enough, in general, the individuals of any one nation could not imagine themselves attacking unprovoked a friendly neighbour, but they believed that a lasting peace could only be secured by armaments. It was a German militarist's boast that by the strength of his country's arms there had been acquired a peace of forty years, a longer period than any known in history.

It was only to be expected that, in order to avoid war, all neighbouring States got themselves into a position of "preparedness," which caused a competition of armaments to spring up. This was considered regrettable and extravagant, but it was said to be unavoidable, and preferable to war itself. It was also said to be good for trade.

Furthermore, in a desire to extend security, an alliance was entered into by some of the Governments, which forced those left out to form an Entente for their own security. Diplomatists were consequently engaged, usefully and otherwise, in seeking to ensure peace by means of a balance of power, while attending to the aggrandisement 
of their respective countries. Owing to the continual fluxing due to invention and in output of armaments, they were kept busy balancing and adjusting, and were so far successful that the inevitable seemed delayed indefinitely.

Nevertheless, the opposing machines of destruction steadily grew, and, although restriction of output was frequently suggested, they never reached a stage of arrested development. The citizens of each country could only hope that when the impending catastrophe did take place it would occur at such a time as would be most propitious for themselves. It was this hope which was father to the disgraceful policies of European warlords.

\section{The Militant Evolutionists and the Imperialists.}

In such an atmosphere, it was the fashion to speak of war, among kindred things, as a means of human progress in evolution. By many the doctrine was mildly held that war, in breaking down antisocial barriers, made the way clear for reform, while others, regardless of reservations, glorified war as the saviour of humanity and the creator of all goodness.

It was the militant evolutionists who rushed Darwinism boldly into politics and proclaimed that "War is a biological necessity." Their favourite theory was that. international rivalries were due to a desire to seek for "a place in the sun for overgrown populations."

Darwin had accepted without question the then current "over-population" fallacy put forward by Mr. Malthus, an eighteenth-century clergyman, and although it had no direct bearing upon Darwin's theory of Natural Selection propounded in The Origin of Species, it was gratuitously employed as an analogy by Darwin, when he stated that the struggle for existence "is the doctrine of Malthus applied with manifold force to the whole animal and vegetable kingdoms."

In a later work, The Descent of Man, he had cautiously to admit that man's environment had been unnaturally tampered with "by laws or customs." He pleaded that "there should be open competition for all men." Dr. Alfred Russel Wallace, collaborator with Darwin, was so 
positive of the harmful effects of man's unnatural environment that in his book, Man's Place in the Universe, he uttered a strongly worded protest when discussing atmospheric contamination.

But the militant evolutionists observed no such scruples. They revived the discredited doctrine of Malthus, scorned Darwin's caution, and echoed from Empedocles, "War is the mother of all good things." "There must be a great struggle for existence between the older nations," said Häckel, " and the strongest, most adaptable and resourceful nations will win."

Such an authoritative lead inspired the Pan-German propaganda: "Every nation seeks space for the affirmation and development of its peculiar character. The result, of course, must be a squeezing, a jostling, a jumping upon one another, and much consequent battling. But let us remember that such struggles for room are not reprehensible, and that, notwithstanding the pain they bring, they are necessary struggles. Nature gives the nations their peculiar characteristics, and it is the duty, the sacred duty, of each to assert these. This can only be done by the acquisition and use of power.'

In Great Britain the imperialists adopted the same views, less brutally expressed possibly. "Freedom must be fought for," said the mildest of them. Bernhardi's effusion -Germany and the Next War-and Treitschke's adulation of war as "the medicine of God" can be matched by Major Stewart-Murray's book, The Future Peace of the Anglo-Saxons and Lord Roberts's tribute that "war is as inevitable as death; it is salutary, it is necessary, and the only natural tonic that can be prescribed."

Incapable of differentiating between the bracing, enjoyable effort misnamed "struggle" for existence in nature and that Black Hole of Calcutta struggle going on among mankind, the militant evolutionists see in war the highest expression of a cruel, remorseless force, which in the course of unnumbered ages has evolved all the infinitely diversified and wonderfully adapted forms of teeming life on this planet. War the great destroyer, according to this doctrine, "is the mother of all good things"! The fittest to survive are the fierce, brutal and power-lustful. 
Frightfulness and ruthlessness are the attributes of the "superman," mercy and pity are but the virtues of the weak. "We ... believe that Will to Life had to be intensified into unconditional Will to Power; we hold that hardness, violence, slavery, danger in the street and in the heart, secrecy, stoicism, arts of temptation and devilry of all kinds, and everything evil, terrible, tyrannical, wild-beast-like and serpent-like in man contributes to the elevation of the species just as much as its opposite-and in saying this we do not even say enough." (Friedrich Wilhelm Nietzsche.) This apostle of ruthlessness was of opinion that "every strengthening and elevation of the type 'man' also involves a new form of slavery": we thus gather that the superman is a slave-owner!

It is a logical sequence that, just as there must arise supermen possessing these characteristics, so super-nations must follow, and, if the imperialist might be said to idealise a millennium, it would be one super-nation finally having in bondage all the others as subject nations. "The weak nation is to have the same right to live as the powerful and vigorous nation!" ejaculated Bernhardi, who regarded the efforts directed towards the abolition of war as immoral and as "unworthy of the human race"-." The whole idea represents a presumptuous encroachment on the natural laws of development."

To provide room for the superman, it was proposed that the "Germanoid" races organise great forced migrations of the inferior races of South America to " reserves" in Africa. This may be an extreme example, but it is only the logical carrying of theory into practice. The proposer (Colonel Reinhold Wagner) believed that such forced migrations might appear superficially hard, but it was the only solution of the race-question that was worthy of humanity. Thus alone could the "over-population" of the earth be controlled and the efficient peoples secure elbow-room. In the narrow "reserves" where the inefficients would have no room to grow, discouraged and rendered indifferent to the future by the spectacle of the superior energy of their conquerors, they would crawl slowly towards the peaceful death of weary and hopeless senility!

South America is the most thinly populated of all the 
continents, but these experts in international affairs saw no method for dissipating the unpleasant symptoms which obtained there except the application of organised violence by "Germanoid" supermen.

Once the principle is admitted there is no escape from such conclusions; the militant evolutionists have the merit of never shrinking from carrying their theories to a logical termination.

\section{Governments and War.}

One of the most important current beliefs with regard to war was its civilising influence upon mankind. It was taught and believed that all government is based upon force. Intelligent mankind during the ages of unceasing warfare had invented powerful Governments to restrain individual ferocity, so that benevolent measures could be promoted for the welfare of the nations, affording security to life and property.

The stronger and more powerful the Government, therefore, the happier the fortunate nation basking in the sunshine of its blessings. But the possession of these advantages of civilisation entails corresponding sacrifices. The balance of nature being thus upset, it was natural to expect that for periods of peace and prosperity, which caused stagnation, overproduction of wealth, luxury and gross materialism, war periods must come to prune, rectify and purify the nations.

That the greater portion of the populations were not afflicted with this superabundance of goods was generally forgotten, but it was believed by those subscribing to this theory that the poverty-stricken were improvident, and preferred, even enjoyed, their state of riotous discontent and misery to any other.

It could not be denied that there was much in appearances to encourage this incongruous belief in war purification. Civilisation could be likened to an organism suffering from sporadic inflammations, how caused it was not clear, but by our deep thinkers they were believed to be due to " overgrown populations" and by our theologians to "original sin." These inflammations came at length to a head, and the enormous eruption of war was necessary to dissipate 
the suppurations, enabling Society, weak and convalescent, to regain its health and morality.

\section{The High Moral Feeling upon Entry into War.}

Many of these ideas found their most pronounced expression immediately before and after the outbreak of war in IgI4. Influenced by high moral feeling, men and even women have committed the most remarkable acts of noble self-sacrifice and bravery in the face of the greatest dangers. Under the same influence they have also committed atrocious deeds of cruelty, but which they justified according to our authority Paley: "If the Cause and End of War be Justifiable, all the means that appear necessary to the End are Justifiable also," a statement which cannot be refuted. As Bethmann-Hollweg, quoting Carlyle, expressed it, " Necessity knows no law."

Germans, feeling surrounded upon all sides by enemies, believed they were fighting for their existence, and Britons rushed nobly to the rescue of the stricken Belgians and French, as the Russians did to the protection of the Serbians. All fought for self-preservation, instinct being intermixed with an intelligent sense of repressed shame.

This secondary emotion, which became stronger as the Great War proceeded, found expression in moralising protests. "It is necessary for us to make it clear to the neutral world why we can be content with nothing less than a victorious peace. It is not for the love of fighting, though we may seem for the moment to have converted ourselves into a military nation." (Mr. Asquith at Ladybank.)

The Churches, in their National Mission of Repentance and Hope, explained "that the repentance is not for the part the nation has taken in this great war. Militarism is not one of our national faults, as witness our unpreparedness, but for which the war might have ended long ago, if, indeed, it had ever commenced. We have therefore no blood-guiltiness, so have not to repent for that. We have entered upon this war in the spirit of chivalry on behalf of the liberties of the smaller peoples. Let us seek to cleanse our nation of the evils that contaminate it," a list being given of these evils, chiefly neglect of religious observances. 
The writer of the above was unnecessarily regretful concerning the extent of our preparedness, ${ }^{\mathrm{I}}$ and was strangely inconsistent in referring to militarism as a "fault," when it might have prevented the war taking place! $\mathrm{He}$ continued: "So that, inspired by self-sacrifice so gloriously presented by the flower of our race, the nation may set its mind on righteousness, and so become worthy to turn the victory for which with all our might we are contending to the purposes of God, of liberty and of the highest civilisation." .

The Churches in Germany referred to British hypocrisy, and the Kaiser wrote to his Chancellor to say that, "It is clear that the peoples of the enemy countries, who are kept in a morbid war-atmosphere and are labouring, owing to lies and fraud, under delusions induced by fighting and hatred, possess no men who are able, or who have the moral courage, to speak the word which will bring relief-to propose peace. What is wanted is a moral deed to free the world, including neutrals, from the pressure which weighs upon all. For such a deed it is necessary to find a ruler who has a conscience, who feels that he is responsible to God, who has a heart for his own people and for those of his enemies, who, indifferent to any possible misinterpretation of his action, possesses the will to free the world from its sufferings. I have that courage. Trusting in God, I shall dare to take this step."

Neither side credited the other with sincerity, although their protestations were made under what appeared to be genuine moral emotion. All "sacrificed" themselves, and the Kaiser Wilhelm, in his rôle as prince of peace, was obviously not conscious of blood-guiltiness.

But the situation was such that any interference, however well intentioned, only added fuel to the fire. The excitement had to be discharged, and those popularly thought able to bring hell upon Europe by merely pressing a button were least able of all to restore peace.

Out of the belief that the Kaiser Wilhelm, the late Emperor of Austria or the ex-Czar of Russia was able to bring about a horrible war, was born a wonder that millions

I Great Britain spent more per head of population upon military establishment than any other country in the world. 
of people should be found willing to die at their bidding and for undisclosed aims.

It is necessary to remind ourselves of the spark which began the Great War. From the Vienna Reichsbote is taken the following: "Austria declared war on Serbia because our splendid heir to the throne had been murdered, and because it was necessary to root out the nests of the conspirators. How absolutely moral was such a motive for war! How grand is the Austrian idea of State!"

Why such a comparatively insignificant spark should produce the great conflagration is the question we have to ask ourselves and seek for solution. We have to discover why mankind has become so dry and sapless that farreaching destruction is possible as the result of a trifling incitement. In our search, the dictum of Baron von Gebsattel, one of Germany's ruling class, may afford some enlightenment: "Political and human rights have nothing to do with one another." Since when was the divorce effected?

\section{What is meant by Militarism.}

Mr. Arthur Henderson also believed that Great Britain was not a militarist State before the war. In reply to an American interviewer who had asked, "What is meant by militarism?" he replied, "An army not kept in its proper place," and added, "Either German military power must be effectively controlled by a Government which has adequate regard to moral restraints, or that power must be so weakened as to cease to be dangerous. What the Allies contend with regard to Germany is that its great military power is not subject to proper moral constraint; that it has not been used in accordance with such constraint."

Mr. Henderson's candour did him credit, but his contention was precisely that of the Central Confederation with reference to the "military preparedness" of the Allies. Mr. Lloyd George, speaking of the confidence the Germans place in their Army, said, "The Germans put their trust in it in a way you can hardly conceive, as we all put our trust in our great Navy." Yet Mr. George contended that the German people hated their Army, because it bullied and terrorised them, but they put up with it so 
long as it intimidated their neighbours. He said, "We have to demonstrate that the Prussian Baal is a false god, that its pretensions are a sham, that its priests are a cruel fraud."

Each side called the other hard names, and Professor Gramzow, after calling the French a nation of madmen, said: "The English are not mad, nor are they hypnotised. What they do is done with cool consideration and reckoning. But there can be no peace or reconciliation with them. The man who believes this possible is neither a psychologist nor a student of history. Behind the English nation lies a history of seven hundred years of crime. The old Norman pirate spirit has never permitted a rival. The ruling caste in England lives and struggles for its moneybags. Righteousness is unknown to it, and moral considerations it has thrown to the winds. The British ruling classes are versed in every vile and knavish trick, and practise unexampled persistence and cruelty. If the power of these people is to remain, they will never rest until they build up fresh coalitions against us. What hate and greed can do, will be done by them. We will therefore not risk future wars. This must be the last, and the political instinct of the German nation says, 'Down with England: this is the solution!'",

We might multiply quotations indefinitely from the publicists of all the warring nations to show that each saw in exaggerated form the faults, believed to be wilful, of the other competitors in the struggle. Each national egotism was afflicted with mental blindness correspondingly with regard to its own faults, and magnified what it conceived to be its own national virtues. We, the Entente, represented ourselves as protectors of the weak, and refused to believe that even "inadequate" preparedness was nevertheless militarism, while the Germans believed they were the chosen people of God sent to chastise surrounding nations into righteousness.

Moderate councils in each country were repressed, and so far as they were expressed were not allowed to find their way into opposing camps to vitiate the will for war. The individuals of each belligerent nation believed themselves to be attacked by unscrupulous antagonists, while 
each in turn deemed themselves peace-loving and inoffensive. Base actions were called by unfamiliar names in a desire to hide their real nature. Unspeakable atrocities were carried on under the name of reprisals.

High moral feeling decomposed into immorality, and considerations of humanity were more and more disregarded on every hand as all sought, assisted by the incantations of the war-priests, accompanied by hymns of hate, to cast out devils by the aid of Beelzebub, the prince of devils.

\section{Fighting for Freedom.}

There was a definite belief fixed in the minds of all combatants that they were fighting either for their own freedom or to secure or to preserve the freedom of others. The freedom fought for was never defined clearly, and so far as it was expressed was generally limited to a statement that freedom from the aggression of militarism and brute force was intended, or that it was necessary to secure the freedom of the seas.

It was not clear from other statements made that the "freedoms" each aspired to were intended in every case to be universal. Indeed, there were many indications which tended to show that forceful discrimination would be made.

By some it was stated that they were "fighting to make the world safe for democracy." Why democracy was unsafe was not satisfactorily explained, but it was sufficiently obvious that democracy was everywhere unsafe. Fighting, however, seemed as ineffective a way to make it safe as the father and mother fighting each other to make the home safe for the children.

That it was necessary to fight for freedom was an implication that we were in a state of captivity. The alleged restraints, curiously enough, were found upon examination to be in effect greater upon those who appeared to menace their neighbours than upon those who believed themselves to be menaced. For example, Prussian Militarism was resented by surrounding nations, but it was only remembered at rare intervals that it was a far greater danger to the Germans themselves.

The mental blindness of those most enslaved in this 
way was only intensified by the haste of neighbours as they sought to enslave themselves in a similar or improved manner. Each competitor nation loaded itself much as Sinbad shouldered the Old Man of the Sea, believing that after the passage of the deluge the burden would be easily unshipped. How it would be disposed of was variously believed to be by the imposition of the charge upon the backs of the losers by the victors.

"Peace without Victory," or "No Indemnities, No Annexations," meant that each should accept responsibility for their own burdens to their own moneylenders, and as this unpopular war-aim provided, or seemed to provide, a ruinous outlook for many in the future, the limitless gamble was continued in a desire to transfer the constantly increasing load upon an insensible competitor after "the Knock-out Blow."

These fears and hopes operated like the action of the blast upon a furnace. The Great Bonfire of the Nations burnt ever more furiously, and as the fires burnt down, new faggots were laid upon the dying embers so long as fuel was available.

\section{A Durable Peace.}

At no time did there seem hope in the victorious waraims of either side for a durable peace in the future. Each clearly saw that a "shameful peace" for themselves could not be durable, yet indicated that they were determined to impose a "shameful peace" upon the other. To the Central Confederation only a "German" peace was supposed to be durable, while the Entente Allies believed that the only durable peace was "Peace by Victory," one as shameful as the other.

War indemnities as "compensation" were discussed by the implacable property worshippers of the belligerents, but this meant a larger scale of "dumping" upon the victors and stimulated industry for the losers.

"War after the war" by means of tariffs could be shown to hurt those who employed such a weapon (except a few favoured individuals) more than those against whom it was directed. Nevertheless, in face of this offence no permanent settlement was likely, for the same reason that 
a man who cuts off his nose to spite his face perpetually offends his neighbours by doing so.

Territorial aggrandisement from the point of view of the victors was seen to be the only thing worth striving for, which accounted for the secret treaties of partition and the sentimental introduction of the Alsace-Lorraine bone of contention; but neither in these war-aims could there be said to be hope for an ultimate durable peace, any more than in the short-sighted and brutally selfish action taken by the German Government in Russia, Finland, the Ukraine, and in Rumania, especially after the professions made by them at Brest Litovsk.

Even "Peace without Victory" contained its dangers. Let us refer to Mr. Balfour's Note sent to the United States of America while they were yet neutral. He said: " His Majesty's Government entirely share the President's ideals [with regard to peace], but they feel strongly that the durability of the peace must largely depend upon its character, and that no stable system of international relations can be built upon foundations which are essentially and hopelessly defective. This becomes clearly apparent if we consider the main conditions which render possible the calamities from which the world is now suffering. These were the existence of a Great Power consumed with the lust of domination in the midst of a community of nations ill-prepared for defence, plentifully supplied, indeed, with international laws, but with no machinery for enforcing them, and weakened by the fact that neither the boundaries of the various States nor their internal constitution harmonised with the aspirations of their constituent races or secured to them just and equal treatment."

Mr. Balfour would scorn a suggestion that his views in any way approximated to those held by Colonel R. Wagner for the segregation of peoples into "reserves," but since this is a time for inquiring into many things believed to be indispensable, we may well ask why are frontiers of States considered any more important than those of counties or provinces?

Mr. Balfour did not put forward any definite proposals of boundaries and constitutions suitable, and likely to meet the aspirations of the constituent races, securing for 
all just and equal treatment, but he certainly presented an ideal for attainment, towards which the Allies might have fought for all eternity without solution, apart from the negative one of ultimate extinction!

\section{Fatalism is Opposed to Common Sense.}

Mr. Balfour was happy in his observation that " no stable system of international relations can be built upon foundations which are essentially and hopelessly defective," but he was obsessed by the fatalistic belief in a yet Greater Power supplied with machinery for enforcing the plentiful international laws against any Great Power filled with the lust for more power.

How could we be guaranteed that this Greater Power would not also be consumed with the lust of domination? Experience teaches that there can be no guarantee, because presumably the underlying system of founded credence is essentially and hopelessly defective.

The Anarchists, who regard government in itself as evil, are not more unreasonable than the imperialists and militarists with their belief in unlimited autocracy, or the Socialists of the militant type with their doctrine of divine right of the majority to tyrannise over the minority. There must be some middle way by which the regulation of society can be effected without tyranny.

That there is something fundamentally at fault which necessitates monstrous, inefficient and top-heavy Governments we are convinced. The regulation of a steam engine would not excite any admiration if its governor absorbed about one-third of the total output of energy, and to show pride in the political mechanism which absorbs this proportion of human activities in what is known as government is an offence to any reasonable mind.

\section{The Problem.}

Our problem is not only to investigate the origin of civil and international hatreds and wars generally, but especially to scrutinise the underlying cause or causes of modern strife. We should then be in a position to indicate the specific remedy or remedies called for. 


\section{THE FALLACY OF FATALISM}

We shall clear away, so far as we can, the debris which strew the path over which we must tread, composed of the fragments and boulders shattered from mountainous fallacies long ago exploded by giant pioneers. These have discouraged former research parties.

On our way towards the source, we may examine certain tributary theories to see where they lead, but not every one. The time is short, our friends remaining behind are anxiously awaiting our news. Guided by the finger of Truth, our expedition must not halt, therefore, but press forward, sustained by the conviction that fatalism is opposed to common sense. 



\section{BOOK I}

\section{THE BIOLOGICAL ASPECT}

\section{CHAPTER II}

\section{HEREDITY, ENVIRONMENT, AND THE RACE QUESTION}

\section{READER'S GUIDE}

IN Chapter II we show that heredity is not responsible for what is known as national characteristics or moods, but that association is. Race relationships are discussed, and a conclusion reached that the races are situated where they are naturally found because they are fitted by Nature for these positions : that any "forced" migration tends to be rectified in course of time: that the natural boundaries of the races are indefinite, and that they cannot possibly coincide with national frontiers, which are arbitrary and definite.

\section{THE HEADINGS ARE :}

National Characteristics-Evolution in Heredity is a Slow Agency-Language as an Example of Evolution in Association-The Ephemeral Nature of Peculiar Characteristics in Nations-Heredity is a Function of the SeedThe Patrician and the Plebeian-The Phenomena of Warlords, Millionaires, Paupers and Criminals-The Races of Mankind-The Disappearance of Intrusive RacesWhy Indigenous Races sometimes Disappear-Superiority in Race not to be Gauged by Culture-The Disposition of the Races in Europe-The Boundaries of the States of Europe and their Constituent Races-The Boundaries of States are not Fixed by Nature. 
Oh, East is East, and West is West, and never the twain shall meet, Till Earth and Sky stand presently at God's great Judgment Seat; But there is neither East nor West, Border, nor Breed, nor Birth, When two strong men stand face to face, tho' they come from the ends of the Earth!

KIPLING.

Slav, Teuton, Kelt, I count them all

My friends and brother souls,

With all the peoples, great and small,

That wheel between the poles.

TENNYSON.

For $a^{\prime}$ that, and $a^{\prime}$ that, It's coming yet, for $a^{\prime}$ that, That man to man, the warld o'er, Shall brithers be for $a$ ' that.

BURNS. 


\section{HEREDITY, ENVIRONMENT, AND THE RAGE QUESTION}

\section{National Characteristics.}

Much has been heard and written of the influence of heredity, and especially of its baneful effects upon the character of nations. As examples of the positive statements made regarding the latter, some of the quotations given in the previous chapter will serve as reminders.

It was Nature, according to the Pan-Germans, which gave the nations their peculiar characteristics, and Professor Gramzow considered that the antecedents of the French and English indicated inherent tendencies which precluded any possibility of future friendship with Germans.

Based upon memories of less unhappy times, more reasonable views prevailed among thoughtful people in every country. In Britain it was frequently stated that, with Prussian Militarism eradicated, the German national character would revert to that of previously accepted conceptions. But there were other opinions expressed, full worthy of consideration, that "once a German always a German," a cryptic saying which was rendered transparent by Mr. Balfour's declaration, "Brutes they were at the commencement of the war, and brutes they remain."

The majority of people held that the criminal policy of the German Government, manifested in unrestricted submarine warfare and other vile atrocities, was inherent in the individual German for all time. "Irresistibly, apparently, to the ordinary German-he may call himself a Socialist, an. International Socialist, or what he pleasesthere is deep down in his nature this predatory instinctthat when success appears to crown his efforts he is like a wild beast falling upon his helpless prey." (Mr. Balfour.) 
There could be cited innumerable cases of "natural" or "racial" hatreds and friendships between nations, but more especially of hatreds. The Slav was supposed to be the natural enemy of the Teuton, and the Turk was believed to be born with an inherited hatred of the Christian Greek. It was thought that there was a natural bond between the American and the Britisher, or between the German and the Spaniard.

It was opined that these were more or less permanent relations based upon the inherited attributes of nations, differences, according to Herbert Spencer, resulting from differences in the units composing the nations. Historians and other writers descanted solemnly upon these attractions and repulsions, and while it was reluctantly conceded that mutations might take place, these modifications were believed to be due to the agency of evolution in heredity.

\section{Evolution in Heredity is a Slow Agency.}

Evolution in heredity is so slow that for all practical purposes it may be assumed to be constant.

Man is of immense antiquity, older than many existing species of lower mammals, and he has outlasted many that were contemporaneous with the childhood of the human race. He lived when the mammoth roamed over Europe and when the mastodon held sway in North America. His origin is lost in the mists of the Miocene period, which, although recent in geological time, yet in years ago must be counted in æons.

During this long period evolution in heredity has gradually modified man's physical and mental capacities, and recent discoveries have shown how extremely slow this process has been. It is only when comparisons are made between the remains of widely separated periods that differences in physical structure can be detected.

During the historical period, extending over eight to ten thousand years, no difference can be observed between representatives of present-day races and the corresponding representatives of their ancestors. It is not only in comparing past races with their present descendants that we realise evolution in heredity to be practically stationary, but in comparing one race with another it is emphasised how little in the lapse of time have their distinctive charac- 
teristics altered. On the walls of ancient Egyptian temples, built many thousand years ago, " the negro and the Caucasian physiognomies were portrayed as faithfully, and in as strong contrast as if the likenesses of these races had been taken yesterday." (Lyell.)

So far as mental capacity goes, an impartial comparison of the quality of the progress made does not support any theory that present-day man is of appreciably higher average mental calibre than the ancient Egyptian, Assyrian, Greek or Roman. Even when we retreat to prehistoric times, it has to be admitted that the skill with which palæolithic man shaped flint knives, scrapers, lances and arrow-heads, and employed them, was not inferior to that of presentday mechanics and sportsmen.

The drawings and sculptures of Quaternary man upon bone or pieces of schist show a strength and technique equal to the art of the Classic Period of Greece, making due allowance for tools and medium. The invention of the firedrill and the discoveries in agriculture and navigation are not less achievements than the invention of the steam-engine and the discoveries of modern science.

Neolithic man had only the advantage over his palæolithic ancestors in the extent of past accumulated knowledge, from which he was enabled to survey a wider horizon. We, their present descendants, may or may not have a greater average mental capacity, and it can only be positively said that we stand upon a higher platform, not that as individuals our mental stature is as much higher. The discoveries of one period are made the common stock and stepping-stone of the next, and evolution in association is to mankind what the development of memory is to the individual.

\section{Languages as an Example of Evolution in Association.}

The study of languages, more conclusively than anything else, shows that differences in nations do not result from differences inherent in the units. None of the tongues now spoken were in existence ten centuries ago, and philologists teach us that present languages are dialects, which have undergone slow transmutation from the ancient tongues as starting-points, and that the latter in their turn have been transmuted from languages still older and also extinct. 
The chronicles and laws of England written in the time of King Alfred can only be understood by the student who has given himself up to the study of Anglo-Saxon. The English of the twentieth century, given the opportunity, could not converse with their ancestors any better than, or even so well as, they could with present-day Germans.

So rapid has been the modifying change in Germany that the epic poem called the Nibelungen Lied, only seven centuries old, once so popular, cannot now be enjoyed except by the erudite. In France the same ceaseless change has taken place. A treaty of peace made a thousand years ago between Charles the Bald and King Louis of Germany, written in the French and German of that period (A.D. 84I), cannot convey a distinct meaning to any but the learned in these two countries.

It is an axiom more securely established than ever since the Origin of the Aryans.controversy that language is no test of race, and a similar axiom applies with equal force to all beliefs, and all the web of ideas within which we live, and which are expressed in language.

\section{The Ephemeral Nature of Peculiar Characteristics in Nations.}

The fact that new ideas are assimilated into the old web to influence and be influenced by the existing ideas only goes to show how ephemeral is the platform of thought and custom upon which we stand. A child does not inherit his father's religion or politics, any more than he inherits a broken leg or other physical defect resulting from an accident. The Janizaries, made up of youths taken from Christian parents in childhood, became to all intents and purposes Turkish, and fought against their own relations as fanatical Moslems.

Members of religious orders like the Jesuits, taken from every race, show distinct character certainly not perpetuated by hereditary transmissions. The Jesuits themselves had a well-known saying to the effect that, given the wardship of a child up to the age of seven, anyone might have the care of his education afterwards. In schools or regiments, where the components remain only for a short term of years and are constantly changing, it is a matter of every- 
day observation that they exhibit a characteristic cant, the result of mental impressions perpetuated by association.

"Racial" peculiarities, which distinguish Scottish Highlanders, Irishmen, Englishmen, Germans and Frenchmen, can all be reversed by the transference of the units from one environment to the other, and their descendants would become indistinguishable after the short lapse of a hundred years from other dwellers of the country of adoption. ${ }^{\mathrm{x}}$

In the case of the Jews, it has only been the tenacity with which they clung to an exclusive religion, which enters into all the affairs of family life, that has preserved their peculiar national characteristics. In countries like England and the United States of America, where the intensity of religious belief has lessened, the outside pressure of suspicion and dislike has died down, and the one time Peculiar People are only with more or less difficulty distinguishable from the Gentiles. During the Great War the Jews fought indiscriminately for the nations among whom they dwelt, and shared the peculiar characteristic war-aims of their hosts.

If, owing to some miraculous cataclysm, the new generation of babies could be separated permanently from the older generations, the latter ceasing to exist, mankind would relapse into a condition of ignorance compared with which the lowest barbarism of which we have record would seem a high state of civilisation.

There would grow up a population which would have to evolve a language and discover the simplest facts we are scarcely conscious of having learned. This hypothetical population would have no knowledge of the rudest tools, know nothing of the use of fire, tillage and the domestication of animals. The whole face of nature would be changed, and the effects would be impossible to imagine or describe.

That after the lapse of many thousands of years all

" An official German Army report captured recently not only speaks in the most respectful terms of the United States soldiers fighting near Château Thierry, but confesses that the German Intelligence Officers were unable to get information from the few Americans they captured. Surprise is expressed that while many of the United States troops captured were the sons of foreign-born parents-some of them were German-Americans-they all had the pure American spirit." (Daily Press, August I6, I9I8.) 
the knowledge would be again acquired and the earth subdued to man's dominion there is little doubt, because the possibilities for it are latent in man's physical and mental capacities; but all the peculiar characteristics said to have been given by Nature would have disappeared. They would be found to be the gift not of heredity, but of association.

This is the reason why Darwin, Dr. Hooker, Huxley and others were so cautious in their mode of espousing the doctrine of progression by evolution in heredity ; and Herbert Spencer made reference to "super-organic environment," a term to cover the body of traditions, beliefs, customs, laws, habits and associations which arise in every community and which surround every individual. It is this which is the great element in determining national character, and obviously it is not inherent in the individual.

\section{Heredity is a Function of the Seed.}

It is more easy to differentiate between hereditary tendency and the influence of environment when examples are taken from the more lowly forms of life. Heredity is a function of the seed, and is the normal symmetry of dimension towards which all deviations for the time being tend to return. During the ages it has been this ever-present property of hereditary deviation which, reacted upon by environment, has motived the production of varieties, from which species have arisen.

But parallel with the progression by evolution in heredity has been progression by evolution in environment, which includes all the conditions under which growth takes place. Environment, as in the case of heredity, has also a normal symmetry of dimension, towards which all deviations for the time being tend to return, and this property of divergence in environment is as important as is that in the case of heredity.

For example, a seed upon the parent tree contains the principle of heredity, sometimes described as the " memory" of the nucleus, determining its future crystallisation into a replica of the parent tree. The growth of the seed while upon the parent tree is influenced by a multitude of conditions even during this short period, calculated to affect its future as a young tree. After planting, external environ- 
ment becomes increasingly important, because even a healthy seed cannot germinate and grow up into a healthy tree if placed in a bad situation, in poor soil out of the sun, or if it experiences exceptional climatic conditions. On the other hand, a poor seed, given suitable subsequent surroundings, might recover from the backwardness resulting from unsatisfactory external conditions during the short time while drawing upon the parent for sustenance. There is an infinite number of combinations of circumstances under which growth takes place, and it is therefore not surprising that no two trees of the same species are individually alike in every respect, although the influence of heredity may have operated equally in each case. Divergence in environment is not less important to the individual organism than variation in the hereditary equation.

These considerations apply with increasing force in the animal kingdom as we ascend the organic scale, especially as regards man, because to a remarkable extent he possesses the intelligent power to modify his own surroundings and those of all living things. It is this power which transcendentally distinguishes man from the brutes, whose instinct or intelligence has not diversified into understanding.

\section{The Patrician and the Plebeian.}

The influence of heredity for the son of the long-pedigree nobleman is upon the average the same as for the son of the helot upon his estate. They begin from the same level as regards the seed, and during the period of gestation the labourer's son may have the better environment.

Despite all theories based upon snobbery, it is subsequent social environment which determines whether the mind that is yet to awake to consciousness and power shall be patrician or plebeian.

By selection in breeding, as in the case of domestic animals, varieties of men might be produced to exhibit as great diversities in bodily shape and character, but only if their mental activity were no greater than that of the lower animals. There are, however, no men and women who would submit to such a process long enough, and all attempts even in slavery have failed, and always will fail.

As we go farther back into the past the base of ancestry 
becomes wider and wider. Taking the generation to average thirty years, it may be said that a man has ten ancestors a century ago, apart from related marriages. He has a million ancestors 600 years ago, ten millions 700 years ago, and one hundred millions going back 800 years. Thus the scavenger may be the descendant of a line of princes, while the blueblood patrician may be the descendant of a swineherd and a milkmaid. Centuries are as seconds in biological time.

\section{The Phenomena of Warlords, Millionaires, Paupers and Criminals.}

An appreciation of the powerful influence of environment helps to explain why a child of ignorant forbears often becomes a leader in thought, and why a child of clever parents has sometimes become a dullard oppressed by their hypercultured dominion.

From our point of view there is no mystery why children of the slums should be so often defective mentally and physically, and it is not necessary to assume hereditary transmission from defective parents. The appalling conditions under which our slum barbarians are forced to live would be hell to the lowest savage. On the other hand, the startling contrast presented by modern public-school girls, developed in healthier and freer surroundings than the hot-house feminine culture of forty years ago, equally finds its interpretation.

While it is not possible to indicate where the tendency in heredity ceases and merges into the stimulus of environment, enough is known to reveal the potency of the dynamic factor of environment, especially for ourselves-that part we have called super-organic. It is clear that we must look for some maladjustment in social institutions to account for the unhealthy phenomena of warlords, millionaires, paupers and criminals.

\section{The Races of Mankind.}

There are clearly marked differences in mind and physical structure in individuals even of the same family, and similar race differences exist in the great family of mankind called races. These differences are due to the geographical, climatical and other variations in conditions under which the 
respective races have developed. Like family likenesses, these characteristics in race are transmitted by heredity.

Anthropologists regard neither colour nor language as tests of race, but look for indications in the shape and size of the skull, the dimensions of the limbs and the section of the hair, which in the Mongols is round, in the Aryans oval, and in the negro races flat. In the intermediate races these characteristics are blended according to intermixture. Racial boundaries are indeterminate, and no definition can be given of what race means exactly. The number of the races varies, according to different authorities, from three races to two hundred.

For ages it was the accepted belief that all mankind were descended from a single pair of parents in a single locality. This monogeny theory of descent has now generally given place to that of polygeny, or descent from several pairs developed in different localities by parallel but not strictly similar lines of evolution. Darwin remarks: "I dispute whether a new race or species is necessarily or even generally descended from a single or pair of parents. The whole body of individuals, I believe, became altered together -like our race-horses, and like all domestic breeds, which are changed through unconscious selection by man."

But it by no means follows from this that the races do not possess a living relationship in blood. The Equatorial Negro and the Blond White of Northern Europe are opposite extremes, but they are graduated one into the other in a series of shades each adapted for life in the localities in which they are naturally found.

"Races become numerically predominant in localities where from physical causes the birth-rate is greatest and the death-rate least. The fair race holds the Baltic lands, the brown race the shores of the Mediterranean, and the black holds the tropics. It is for this reason that intrusive conquest or colonisation has usually left little or no trace." (Canon Isaac Taylor.)

\section{The Disappearance of Intrusive Races.}

Hybridisation in races or sub-races is not considered a cause of new races, but as rather tending to keep variation within bounds. Varieties or sub-races which are nearly 
allied (i.e. living in adjacent districts) cross readily with each other and with the parent stocks, and such crossing tends to keep the races true to type. Races less nearly related, although they may intermarry, produce no offspring capable of perpetuating their kind. There is a natural repugnance against union in such cases, which is shared by each side, and only overcome in unnatural circumstances such as slavery.

While the Berber and the Arab or the Arab and the negro readily cross and their progeny are fertile, the halfbreeds between the Anglo-Saxon and the negro races tend to become sterile.

In the West Indies, where the climate is similar to that of tropical Africa, the negroes succeed; but are feebler in Canada and New England, where they are carried off by pulmonary diseases.

In Jamaica and Haiti the yellow fever proves deadly to the whites, and they and the mulattoes also become sterile. Thus the type is relapsing into pure negro, speaking a corrupt English jargon, a witness to their former slavery.

The offspring of Southern Europeans and negroes are more fertile; but it is said that without an infusion of fresh blood no race of mulattoes has maintained itself to the third generation.

The effect of an unsuitable climate is to enfeeble the constitution so as to prevent recovery from ordinary diseases. In tropical and subtropical lands the intrusive races of the temperate zone succumb to gastric and hepatic disorders.

In India the children of Europeans fade away unless they are sent home to the natural environment of the race before they are ten years old. There is in India no third generation of pure English blood, and the Eurasians do not possess the vigour of their fathers nor the adaptation of the mothers to the Indian climate. As in the case of the halfbreeds of many other widely divergent races, incongruous heredity is reinforced by the clashing of incongruous social environments, and the Eurasian falls between two moralities in a special sense, owing to the strong caste prejudices of the native races.

Egypt is a remarkable example of the persistence of the indigenous type. None of the numerous invading races have 
been able to naturalise themselves, and the Fellah still exhibits the precise type to be seen upon the ancient monuments. The Ptolemaic Greeks have been absorbed without a trace; the Mamelukes were unable to propagate their race; the Albanians and Turks are mostly childless; and there is great mortality among the negroes owing to their susceptibility to the plague.

The rule that fair races only succeed in temperate zones is well exemplified by the almost total disappearance of the Vandal element from Northern Africa; but as illustrating the more particular adaptation of races to the home environment we now find little trace of the Goth in Spain or the Lombard in Italy.

Southern Germany was originally Celtic or Ligurian, invaded by Teutons in prehistoric times, but the population has now practically reverted to the indigenous type and is only Teutonic in speech.

A more modern instance of the reversion tendency to native parent type is furnished by the Griquas, a once numerous race of half-breeds between the Dutch Boers and the Hottentots. The Griquas have now practically all reverted to the Hottentot type.

In Mexico the native Aztec race shows a continually increasing predominance over the descendants of the Spaniards.

\section{Why Indigenous Races sometimes Disappear.}

When the intrusive race is suited to the environment it may succeed and flourish, as the European has in the temperate zones of the American continent, and as the negro in the Gulf States and the West Indies.

In such cases the indigenous races have often tended to disappear, and it is sometimes stated that this is evidence of the superiority of the intruder. The Maories, Tasmanians, Australians, Fijians, Sandwich Islanders and Red Indians have all contracted before the Anglo-Saxons. This, however, is not due to the absolute superiority of the latter, any more than that the negro is the superior of the native Carib or the European.

The causes of the disappearance of indigenous races in such circumstances have generally been traced to some 
violent interference in environment, not necessarily or even generally physical interposition, introduced by the intrusive race. Conditions of life may be suddenly altered for the savage hunter, who may be called upon, and may be unable quickly enough, to change his habits. Entirely new habits are slowly learnt, and the transformation from hunter to shepherd or from shepherd to agriculturist cannot be immediately accomplished.

In possession of horses introduced by white settlers, the Red Man, with complete absence of foresight, began to exterminate the bison, which was his principal means of subsistence. The tribes organised great drives, drawing wide cordons round the herds, and slaughtered with all the selfish wastefulness of the white big-game hunter. In I889 it was said that only about one thousand bison remained in the whole of North America, and the demoralised Red Indian was rendered an easy prey to the destructive effects of civilised vice and disease. In a similar manner the Australian blackfellow suffered from the destruction of the kangaroo.

New diseases, introduced by settlers, have played havoc amongst native populations, ignorant of the necessary treatment for minimising their effects or localising the outbreaks. The first epidemic of measles in Fiji carried off half the population, and smallpox and scarlatina have elsewhere proved equally deadly.

New forms of slavery have often been the cause of shrinkage in native races, when they have been subjected to conditions compared with which their feudal services to their own chiefs seemed absolute freedom. Other mysterious cases of dwindled native populations following the invasion of the white man, when investigated, do not afford cause for extravagant racial pride on the part of the latter.

\section{Superiority in Race not to be Gauged by Culture.}

Races, like individuals, are not equal, but it is as unsafe to assess values comparatively in the one as in the other. The conclusions arrived at by many travellers are as unreliable as observations made by savages would be after a flying visit to a civilised land, and even anthropologists have sometimes allowed prejudice to bias judgment in their mechanical assessments. 
Progress attained in civilisation does not constitute a criterion : the most advanced races to-day were barbarians when the Egyptians and Chaldæans had long been highly cultured. We are not able to say, any more than they, which of the barbarian races will advance if and when we retrogress. Capacity for advancement does not seem to be the especial property of any race or races, or to be due to situation upon the earth's surface.

Buried mounds mark the site of ancient civilisations in lonely swamps, the present miserable inhabitants regarding with indifference or superstition the work of their ancestors, while new civilisations have grown up thousands of miles away in different climes among remote one-time barbarians.

As a general rule, races indigenous to the soil may be considered to be the most efficient in the natural situation in which they are found, and this applies equally to the surrounding welding admixture between naturally contiguous races.

It is natural and beneficial for man to travel, explore and trade, and if left to himself, uninterfered with by Governments, he will colonise where he will fitly survive. "Forced migrations " react disadvantageously for the tyrants, while bringing disaster upon the victims. Populations are only "inconvenient" when they are forcibly removed from their natural environment or have an unnatural environment forced upon them.

The doctrine of the "White Man's Burden" is based upon a gratuitous assumption that any race has a right to dominate another. That it is necessary to exploit coloured races to prevent their exterminating each other is a piece of fallacious humbug.

It is a curious illusion possessed by certain people that white races are too civilised to fight, while the fact is that they are interminably at war either with each other or with coloured races. The fallacy should for ever disappear in view of the culminating spectacle presented by the Great War, in which almost all the white natives of Europe and America have taken part.

Dogmatic assessments of racial values, gauged by comparative attainments in culture, have been made, but they are conflicting and entirely misleading. Since differences in civilisation do not inhere in the individuals, but are differences 
resulting from the conditions under which these units are brought, it is impossible to make absolute comparisons in individual worth until they live in a society giving each equal opportunity. It is almost impossible to assess absolute values in race until all races have equal opportunity.

\section{The Disposition of Races in Europe.}

At one time it was generally believed that Europe had been colonised by successive waves of Asiatic migrations, each later wave overcoming the previous settlers by conquest.

These migrations were sometimes picturesquely referred to as " hunger marches," or compared incongruously to the swarming of bees, and one romantic writer went so far as to attribute the presence of Iberians to immigration from ancient Egypt caused by "unemployment." In this way he succeeded in explaining to his own satisfaction the erection of Stonehenge as the product of Egyptian workmen out of regular employment!

These speculations as to the origin of the Aryans still linger among some philologists, based upon a belief that in Sanskrit and Zend the nearest approach to a common language has been discovered. The whole theory, however, of successive migrations of Aryan tribes from the East-a theory which was due to Max Müller and others-received a fatal blow in the arguments set forth by Johannes Schmidt, Dr. Schrader, Huxley and Canon Isaac Taylor, and it is now almost universally discarded. So far as linguistic evidence goes, it was found that in other branches of the Aryan language more archaic elements existed, especially in Lithuanian.

For the anthropologists Huxley sums up the latest evidence for the disposition of historic and prehistoric races in Europe as follows :

I. Blond long-heads of tall stature, who appear with least admixture in Scandinavia, North Germany and parts of the British Islands. (These are the Teutons, of which the Swedes are probably the purest example.)

2. Brunette broad-heads of short stature in Central France, the Central European Highlands and Piedmont. These are identified with the Ligurian race, and their most typical modern representatives are the Auvergnats and Savoyards. (These are sometimes termed the Celtic race.) 
3. Mongoloid brunette broad-heads of short stature in Arctic and Eastern Europe and Central Asia, represented by the Lapps and other tribes of Northern Russia, passing into-

4. The Mongols and Chinese of Eastern Asia.

5. Brunette long-heads of short stature-the Iberian race.

Huxley remarks: "The inhabitants of the regions which lie between these five present the intermediate gradations which might be expected to result from their intermixture. The evidence at present extant is consistent with the supposition that the blond long-heads, the brunette broadheads and the brunette long-heads-i.e. the Scandinavian, Ligurian and Iberian races-have existed in Europe very nearly in their present localities throughout historic times and very far back into prehistoric times. There is no proof of any migration of Asiatics into Europe west of the basin of the Dnieper down to the time of Attila. On the contrary, the first great movements of the European population of which there is any conclusive evidence are that series of Gaulish invasions of the East and South which ultimately extended from North Italy to Galatia in Asia Minor."

\section{The Boundaries of the States of Europe and their Constituent Races.}

Imagine the map of Europe coloured to represent the disposition of the races forming the population. It will be seen at once that the existing boundaries of States do not harmonise, nor can it be said that the obsolete boundaries of States have at any time harmonised with the boundaries of the areas occupied by the races.

To represent the varieties forming the complicated weld of intermixture, the colours merge gradually one into the other until definition of boundaries, so far as race is concerned, is entirely lost. The enclosing boundaries of the States of Europe, including Great Britain, and the provinces composing these States, only form sections arbitrarily selected of colour conglomeration in race. It is obviously impossible in the circumstances to satisfy at any future time the ideal put forward by Mr. Balfour. 


\section{The Boundaries of States are not Fixed by Nature or God.}

While there may be good reasons for divisions into counties, provinces and States, the evidence does not support a belief that Nature designed them, or intended that the peoples living within these arbitrary areas should segregate themselves egotistically. On the contrary, it would seem that frontiers surrounded by fortifications and customhouses must set up strains and generate discordances in racial and international relationships. That the natural aspirations of the races harmonise in the most intimate way is in accordance with the facts of natural phenomena in regard to the disposition of the races upon the surface of the earth.

The aspirations of nations do not inhere in the individuals composing them, but are the outcome of association. The peculiar characteristics which compel them "furiously to rage together" and within themselves were not given by Nature. Inherited attributes upon the average are symmetrical, durable and harmonious, and there is neither harmony nor permanency in national characters, or rather moods.

Before the Crimean War the average Englishman hated the Frenchman and trusted his German "cousin." It was a common saying, "The Frenchman is the natural enemy of the Englishman." Nelson honestly believed the French to be the children of the devil.

The change from gushing friendship to bitter hostility and vice versa can take place with disconcerting suddenness. Contrast the British feeling in regard to the Russian people in September IgI4, when their armies were moving like a tidal wave to the support of their allies, with the execration manifested in I9I8. In I9I4 the Russian character was variously described as simple, sincere and full of beautiful faithfulness, while in I9I 8 the same people were almost universally believed to be inhumanly barbarous and treacherous. Heredity was not responsible for these vagaries.

The bitter and the sweet moods of the constituent parts composing each nation are as transient. There is no ineradicable hatred between Bolshevik and Menshevik, 


\section{HEREDITY AND THE RACE QUESTION}

between Ulster and the rest of Ireland, or between the Catholic and the Protestant. The political differences of the Free Traders and the Protectionists can be composed, and the industrial strife between so-called Capital and Labour is attributable to human institutions, which may be adjusted by human understanding.

We are forced to the conclusion that the boundaries of countries possess the significance they do because of artificial inharmony in the internal constitution of the various States. It is reasonable to suppose, therefore, that when individuals composing the communities have just and equal treatment secured to them, the egotistic attributes of creeds, parties and of the States themselves will gradually disappear.

Race problems will then settle themselves, because neither Yellow, Black nor White, forced out of their natural situation, really desire to be domiciled on a part of the globe where their happiness and preservation are at stake. 



\title{
THE PRINCIPLE OF POPULATION
}

\author{
READER'S GUIDE
}

IN Chapter III we discuss the Principle of Population, and demonstrate that " over-population" is not the Act of God or Nature, but is within the scope of our choice, and is due to some interference in our environment owing to superstition.

\section{The Headings ARE:}

"Overgrown Populations"-Poverty among Mankind and the Lower Animals-Darwin's Perplexity-Some Preliminary Considerations-The Mystery of Matter-The Phenomenon of Life-The "Birth" and Growth of Crystals in an Environing Solution-The Growth and Multiplication of Organisms-Associated Communities of Cells-Youth, Maturity and Dissolution-Nutrition and Reproduction-The Proportion of the Sexes-The Plant Kingdom and its Environing "Solution"-The Animal Kingdom and its Environing "Solution"-Man's Capacity and his Limitation-The Indestructibility of Matter - The Extinction of Races and Species. 
Little Joan, who has wakened in the night, to her mother: "Mother, if a poor boy came to you, would you turn him away ?'

"No, dear. Go to sleep. What is troubling you ?"

"If he were cold and hungry, would you feed him ?"

"Yes, my darling; of course I would."

After a short silence: "Mother, why does God make poor children ?"

Science is bound by the everlasting law of honour to face fearlessly every problem which can fairly be presented to it.

LORD KELVIN. 


\section{THE PRINGIPLE OF POPULATION}

\section{"Overgrown Populations."}

It is remarkable that the origin of war should be frequently attributed to the same thing as poverty, namely, overpopulation. That these dual symptoms are believed, even though erroneously, to be due to populations overgrowing themselves is some reason for suspecting that organised violence and the unequal distribution of wealth do in fact possess intimate relationship.

The hoary and decrepit fallacy put forward by Malthus, that population tended to increase at a greater rate than subsistence, was interred long before the Great War by Henry George particularly, ${ }^{x}$ who explained how "overpopulation" was really produced. Nevertheless, its spook still walks the earth, and is referred to as a living theory by estimable clerics, Fabian supermen, and even scientific gentlemen.

These, with the point of view of the Sadducee, quote J. S. Mill with gloomy severity: "Little advance can be expected in morality until the producing of large families is regarded with the same feelings as drunkenness or any other physical excess."

Moreover, misled by deceitful appearances, there is sporadic interest taken in the ghostly illusion of Malthus by the imperialists. In a pre-war age of superstition, the complacent acceptance of a doctrinal anomaly, that it was natural for those who produced wealth to be impoverished, was in accord with a similar belief that it was a "sacred duty " for one civilised nation to set its unrequited wealthproducers to kill similar citizens of foreign countries. Those who said that "War is a biological necessity" considered this method of diminishing populations better than civil

I See Progress and Poverty. 
strife, in which respective citizens of each nation slaughtered one another in the struggle for "a place in the sun."

\section{Poverty among Mankind and the Lower Animals.}

Poverty among free animals in nature is of rare occurrence, and exists only when abnormal climatic or other conditions supervene. At times of temporary poverty, say among herds of cattle, all suffer in equality alike, just as they enjoy equally the opportunities in times of plenty. Hence the most industrious animals in search of food at any time are usually in the best condition.

Among mankind, on the other hand, we were presented before the outbreak of the Great War with the extraordinary spectacle of large industrial sections of the population of every land, mainly in those countries proud of their civilisation and wealth, who were suffering from interminable famine even in times of comparative prosperity. Concurrently, other sections, not necessarily industrious, of the same communities had a superabundance. Since the close of hostilities, the unequal distribution of goods has rather increased and poverty has become more widely spread.

In pre-war days it was alleged that the poverty was due to the thriftlessness of the poor, who were, moreover, lazy and shiftless; but while this may have accounted for some cases, it by no means accounted for all, nor did it provide a reason for the overflowing plenty of the idle wellto-do. There were certainly innumerable instances of discouraged men and women who allowed themselves to be broken down, trodden into the mire of vice, dirt and hopelessness, but this fact did not prove the truth of the allegation, only that indigence which is hopeless destroys all vigorous exertion.

It is in man's power by virtue of his special intelligence so to provide for the future that he can cover any conceivable combination of adverse circumstances, and thus he need never suffer even the occasional periods of poverty felt by the helpless lower creation. To a large extent he has already achieved this consummation by world-wide commerce, and there is no reason, short of his own short-sighted acts, why there should be famine in any country. 
Since a multitude of honest toilers working long hours, engaged in producing wealth for themselves and others, often end their days in abject poverty, while others, without exerting themselves, accumulate vast possessions, it is simply unreasonable to infer that this state of affairs is the result either of inherent tendencies or inadequate capacity on man's part to produce and exchange.

It is reasonable to believe that there is something wrong with our super-organic environment!

\section{Darwin's Perplexity.}

Owing to his Malthusian atmosphere, Darwin was frequently led into awkward positions. It is evidence of his greatness, however, that he was free from any tendency to subordinate facts in deference to chauvinistic sentiment, and thus he did not allow his common sense to be enslaved by mere preconceptions.

In spite of the plausible reasons given and the superficial seeming necessity for interference, he cautiously deprecated putting into practice the teachings of the neoMalthusians, pointing out that such interference would operate as a prudential check upon the multiplication of better members of society.

As an example of Darwin's perplexity, under the heading of "Extinction of Races," in the Descent of Man, he demonstrated that the change which brings about the disappearance of species or races may be scarcely discernible, that it is not requisite to believe that some cataclysm is necessary in order to extinguish species of either plants or animals. On the American continent, within quite recent geological times, not only many species but whole genera have disappeared, there being no evidence of violence. In some cases of disappearing varieties or races, he observed that only slightly lessened fertility was responsible for the shrinkage.

If increase of population were so pressing that, in addition to great mortality due to accidents and attacks of enemies, it were necessary also for disease, vice, misery and starvation to claim their toll, then no delicate balance could be said to exist. Yet such a balance undoubtedly does exist. 
There is a limiting dimension to the racial quantity just as there is an average size for the individual. But the earth is very thinly peopled, and growth of populations persists towards this limitation in spite of artificial restraints, nor can Art extend the boundaries of the races beyond those set by Nature.

We see a similar limitation in the proportion of the sexes, which Darwin was perplexed to discover did not admit of solution according to the theory of natural selection. The fact that the proportion of the sexes is maintained without the necessity of painful checks is not more incredible than that without painful disease, vice and misery, Nature provides naturally for the principle of population.

\section{Some Preliminary Considerations.}

Every student of nature is familiar with examples of limitations which prevent tendencies of some kind running beyond normality and resulting in dangerous consequences.

Because water as it cools contracts, becomes denser and sinks to the bottom, it might be assumed by an inexperienced observer that water would therefore freeze from the bottom upwards. Disastrous consequences would ensue to organic life upon this planet if perchance it did so, but Nature provides that just before freezing-point is reached water expands slightly, and the formed ice, being lighter than the liquid water, floats upon the surface and thus checks radiation of sensible and latent heat.

A structure with a high centre of gravity is unstable when at rest, but that fact is no ground for disputing its stability when in motion; the sceptic would have to deny stability for the spinning top and the bicycle in motion.

Grains of sand are blown about in the wind; why, therefore, are not blocks of greater dimensions and of the same material ? The reason for the limitation is based upon the fact that mass increases as the cube of the dimension, while the surface exposed to the wind pressure increases only as the square.

Because a baby doubles its weight in six months is no warranty for assuming that it will do so indefinitely. It would be absurd to conclude that this was the tendency of growth increase, but that, owing to the means of subsist- 
ence increasing at a lesser rate, there was automatically provided a starvation check by providence, which was reinforced by those of vice and misery developing as the child reached wicked manhood!

Vice and misery, shrinkage and distortion in the individual as in the race do exist, but they are symptomatic, allied to war and civil commotion, the cause of which we are seeking.

It is important to preserve a due sense of proportion.

Upon the assumption that each child reaches maturity and that each female is fertile, then every woman must give birth to two children in order to sustain the present population of the earth in quantity. But some children die in childhood, others perish before marriageable age, as the result of disease or accident ; many are not fertile either by nature or from choice. In order, therefore, to sustain the level of the earth's inhabitants in number, each mother upon an average must have nearer four than three children. But this is an average, and thus a family of six or more must be common, if population is not to suffer a decrease in numbers.

That the means of subsistence is not the most potent factor regulating the size of families is a fact which requires no enlargement. Even ducal families, with a premium put upon succession, frequently become extinct. A tendency to increase in numbers among the "higher" classes is often reversed into a tendency to diminish as idleness and luxury enervate descendants.

On the other hand, there is a high birth-rate accompanied by a high death-rate among those living an animal existence. The inhabitants of unhealthy city and village slums are frequently diseased mentally and physically, and it is a common saying in which there is much truth, "The large family is Nature's last effort to continue the race." How often such progeny die prematurely or are sterile, brought up under the same conditions as the impoverished fathers and mothers!

In an abnormally dry situation, or after a severe long winter succeeded by dry, fine weather, the gardener is familiar with the appearance of plants running rapidly to seed in an attempt to propagate themselves, the parents perishing 
in the struggle. But human poverty manufactured by social maladjustments is not temporary in an intermittent sense; hence side by side with never ceasing premature decay and death there exists also stimulation to excessive reproduction in the unconscious effort to continue the race.

In new countries, for a different reason, large vigorous families are common. It is instinctive to provide against the greater risks in the wilderness; moreover, the happiness and welfare of each individual are increased in a greater ratio than the increase in the total number of social units. Population, in a new country possessing a suitable climate for the settlers, sometimes doubles in twenty or thirty years, but this tendency to increase is not sustained indefinitely in the race any more than in the individual.

These are preliminary considerations. In order to exorcise once and for all the bogy of "overgrown populations," let us overcome its excusable repugnance to scientific examination and induce it to enter the biological theatre for dissection and analysis.

\section{The Mystery of Matter.}

To explain recent wonderful discoveries in radio-activity, old hypotheses have had to be abandoned and replaced by new ones in accord with the truths arrived at by observation or experiment. It is suggested by modern physicists that there is nothing involved in the material universe save æther and energy. The material substances, which seem so real and substantial to us, are according to modern theories only patterns and textures woven out of the intangible æther. ${ }^{x}$ Electricity, magnetism and motion are the physical trinity of the cosmos, the manifestations to our consciousness of the infinite Intelligence.

The universe has not been founded upon a blind series of accidents, although it may appear that in this way we have discovered something about it. It is, so far as our limited reason can pierce the veil surrounding the God-

- By introducing a new set of axioms of space and time, the latter being regarded as a fourth dimension, Einstein in his theory has cleared up certain difficulties residing in the retention of æther medium in our conception of matter, so that the latter need only be regarded as a manifestation of energy or intelligence. 
Nature, the resultant of intelligent, purposeful and orderly evolution, the beginnings of which we are not able to trace to the source, nor are we permitted to foresee its destined end.

\section{The Phenomenon of Life.}

Far back in the nebulous past, when the solar system had not condensed into a sun and planets, there was always manifested that affinity of one particle for another, the natural law of gravitation discovered by Newton, and comprehended in the statement that any two particles of matter are attracted in direct proportion to their mass and in inverse proportion to their distance squared.

By biologists this fundamental all-pervading physical law is believed to be the origin of all sensation- "asleep" in inorganic "life," "dreaming" in lowly organic, and in varying degrees moving and awake in the higher forms of life. There must be intelligence in what we know as inanimate matter, since intelligence has come out of it.

The process of millions of years by which intelligence has been actively manifested in ourselves is that of progression in evolution. By the older biologists it was thought that this progression was due to a compelling struggle for existence in a hostile environment, but it is now being realised that it is rather due to impulsion towards happiness in a neutral environment.

From the fundamental trinity of electricity, magnetism and motion there have grown during the past existence of the planet many elaborate diversifications. Electricity has been made manifest in the multitudinous forms of inorganic and organic life, magnetism in many affinities, including that of sex, and motion has been revealed in sensation of the unconscious sort, conscious instinct and the higher intelligences.

It is scientifically unassailable to say that there is no death or extinction of intelligence. The indestructibility of intelligence is as real as the indestructibility of matter. The phenomenon of wakeful activity is only one sector of a continual cycle like day and night. There is an alternation of activity and sleep, and each rest in the cycle refreshes, or should refresh, the transmitted "memory" of heredity. The 
lengthening capacity due to progressive development in evolution is similar to the lengthening diurnal period which has taken place during the geological ages of the earth by reason of the tides.

All is life, there is no death: we awake again in the children of the race, and the intelligence of the dissolved individual falls " asleep" into the common fund of Nature.

\section{The "Birth" and Growth of Crystals in an Environ- ing Solution.}

It is in the process of crystallisation in an environing solution that the principle of population is most simply illustrated, the crystal being the most perfect form of inorganic individuality.

Crystals grow by the deposition of fresh solid matter upon their surface, differing to this extent from all plasmic bodies, which, being semi-fluid, take new matter into their interior. But because the principle of growth is the same, following the same laws, biologists have employed crystals for the purpose of elucidating the growth of living organisms.

The limit of growth in the crystal is reached when the internal cohesive force of the building molecules is overcome by the force of gravity of the earth. The internal affinity and the external limiting action are in reality due to one and the same law of Nature, the law of gravitation.

A crystal in the environing solution will not grow unless the solution is in a super-saturated condition, and when it reaches a definite size, determined by its chemical-molecular constitution, the solution yet remaining super-saturated, a number of small crystals appear upon the large one. They in turn proceed to grow and develop until the limit of size is reached.

When the solution is reduced to the condition of saturation, no further multiplication takes place. The tendency in a solution which is slowly evaporating is for the growth of quantity of crystals so to advance as to balance exactly, and to keep the solution at saturation-point. .

Crystals are not "born" when they are not wanted, and a condition of "overpopulation" of crystals, unless the environing solution is interfered with, is a physical impcssibility. The crystals themselves cannot multiply so as to 


\section{THE PRINCIPLE OF POPULATION}

outrun subsistence, and if the solution be diluted artificially to a condition of under-saturation, crystals only dissolve until saturation-point is reached. That is to say, either the crystals are completely dissolved or a few are. Thus, although temporary poverty may occur, a state of interminable poverty cannot be produced. In the nature of things, poverty is a transient condition, and this is contrary to the Malthusian doctrine.

\section{The Growth and Multiplication of Organisms.}

The chief characteristic of organic life is what is known as metabolism, the process causing the conversion of food into plasm. Metabolism is determined by the vital force by which new living matter is formed. By this means the nutrition and growth of the living being is effected, and also its reproduction, similar to the transgressive growth of crystals.

The principle of growth in the living organism shows only diversification in the progression by evolution. It is, "The limit of individual size is determined for each species by two factors - the inner constitution of the plasm, which is inherited, and the dependence on the outer environment, which controls adaptation." (Häckel.) That is to say, the growth of a moneron or of any cell is restricted in a similar manner to the growth of the crystal. The growth of the quantity of cells is likewise only an extension of the growth of the individual, restricted by gravitational considerations, remaining stationary in quantity in an environment saturated with subsistence. When, in the case of the bacterium, the supply of food equals the demand of an existing number of cells, a condition of quiescence is assumed, and no further cleavage takes place. The cells cannot increase so as to outrun subsistence, and only resume multiplication when they exist in an environment super-saturated with food.

\section{Associated Communities of Cells.}

Any animal or plant is composed of millions of cells, the affinity of which is due to unconscious impulsion on their part to co-operate for happiness and preservation, to the ultimate happiness and preservation of the community of cells forming the highly organised individual. In ourselves 
some cells fulfil the function of the skin, others that of the supporting bony structure, the internal organs and so forth, while others yet again circulate and serve the whole community of cells, as the blood and lymphatics.

So long as our outer environment is natural, i.e. within the scope of our inherited constitutional power of adaptation established by countless ages of associated " memory" in evolution, the cells of our bodies obediently respond, without necessity of conscious interference on our part, voluntarily carrying out their several duties in the division of labour. Indeed, any interference or self-abuse is manifested in injury followed by disease.

\section{Youth, Maturity and Dissolution.}

The cells of the association which we call our body are continually being used up or dissimilated, and concurrently built up or assimilated. In youth, assimilation gains upon dissimilation until maturity is reached, when the income and expenditure of cells balance one another. In old age, a reversal takes place, and dissimilation increases in the cyclical process until it constantly gains upon assimilation and the dissolution of the individual ultimately ensues.

The period of youth in the human animal is about twenty years, and since in the order of primates the total period of life averages five times that of the period of youth, a man normally should live until he is a hundred. This he should do in full possession of his faculties, the brain being the last organ of the body to mature and the last to deteriorate.

Just as new crystals appear when the limit of size is attained in the existing crystals, so likewise, as the limit of size of the human individual is reached, there is transgressive growth or reproduction, which is regulated in normal circumstances by the complex differentiation maintaining the happiness of the parents.

\section{Nutrition and Reproduction.}

Nutrition and reproduction are the two basic instincts inherent in the inner constitution of the plasmic cells which compose our bodies.

From these two primary instincts there have been extended during the course of the ages diversifications in 
secondary instincts and in intelligence, which have spread into branching ramifications similar to those of the species themselves. The higher in the organic scale, the more advanced are these trunk and branch extensions of the primary instincts.

In the case of man, his activities form great kingdoms, the boundaries of which are of almost immeasurable extent. $\mathrm{He}$ is an animal, but, like the mythic earth-tree with its roots in the soil, the topmost branches of man's mental and spiritual nature may blossom in the heavens.

Man does not live by bread alone; mere subsistence is a minor factor in the equation of environment for which he is constitutionally adapted. "He braves the scorching heat of the desert and the icy blasts of the polar sea, but not for food; he watches all night, but it is to trace the circling stars. He adds toil to toil to gratify a hunger no animal has felt; to assuage a thirst no beast can know." (Henry George.)

Human thirst for knowledge is equalled by the human capacity manifested in transgressively growing far beyond the limits set by organic capacity. Power of locomotion is extended into machines, which travel at great speed over land and sea or fly through the air. To assist man in producing these inanimate parts of himself, he employs extended arms in a multitude of power and hand tools.

In personal adornment, in the dwellings and home surroundings to which we extend our affections, in the musical instruments with which we reinforce our vocal power, in the thousands of the brain's progeny, the instinct of reproduction is the elementary 'essence from which all spring. That is why we value most the things we construct with our own hands or purchase in exchange by the fruits of our services. Possessions to which we are justly entitled, individually or in co-operation, are in fact extensions of our organic organisation. "The sacred rights" of property, the product of human labour, is no mere figure of speech.

\section{The Proportion of the Sexes.}

In the Descent of Man Darwin confesses: "I formerly thought that when a tendency to produce the two sexes in equal numbers was advantageous to the species, it would 
follow from natural selection, but I now see that the whole problem is so intricate that it is safer to leave its solution for the future."

There is a very simple solution at hand in the theory of transgressive growth. That the sex quantities should be constant and equal is an unavoidable consequence of the growth principle, intermediate complexity only attending cases of sex-differentiation, illustrated in bees, wasps, ants and termites.

The quantities (not necessarily numbers) of each sex obviously form branchings of transgressive growth, bearing the same relationship to each other in any species as do the opposite poles of a steel magnet, of a crystal, of the earth, which is a large crystal, or of the universe itself. One cannot exist without the other.

In mankind there is a tendency to produce the sexes in equal numbers. It is idle controversy to compare sex values for the purpose of saying which is greater. Just as the south magnetic pole is as important as the north, but opposite in polarity, so the woman and the man are equal complements of each other. It is for this reason that female infanticide cannot cause a tendency to maleproducing in the race, any more than amputating thumbs can perpetuate a thumbless tribe. It is also disclosed why any institution of polygamy or polyandry inevitably results in disaster, but it does not follow that against their will the individual of one sex should be bound irrevocably to the other in marriage.

\section{The Plant Kingdom and its Environing "Solution."}

The plant, by means of its chlorophyll granules under the influence of sunlight, is able to form by synthesis and reduction new plasm out of simple inorganic compounds as food.

These compounds are mainly (a) water evaporated from the sea, and rained down from the clouds; $(b)$ carbon dioxide, a product of animal or other combustion, and always forming part of the atmosphere; $(c)$ nitric acid and ammonia, formed by the action of atmospheric electricity and also a product of the dissimilation and decomposition of animals and plants; $(d)$ mineral salts and iron from the 
soil. Except for the latter, all the constituents taken from the "solution" of the plant kingdom are supplied by the atmosphere.

When surveying the vegetation of the country-side, it is interesting to bear in mind the fact that, except for a proportion averaging about I per cent., plant life, including the forest trees, comes not from the soil but from the air.

Plant life cannot increase so as to outrun subsistence. Carbon dioxide in the atmosphere never falls below a certain percentage anywhere, that is, the "solution" is always "saturated." There are seasonable variations, which the plant kingdom is adapted to bridge over, but anything approaching sustained poverty in the Malthusian sense is utterly impossible.

\section{The Animal Kingdom and its Environing "Solution."}

The animal kingdom, either directly or indirectly, subsists upon the plant kingdom, which is its environing "solution." It may be generally said that the plant kingdom is the agent of assimilation, while in the animal kingdom, on the contrary, dissimilation preponderates, the plant plasm being resolved by oxidation in a complex process of analysis, in which albumin assimilation for growth and reproduction of the organism is produced and energy manifested in animal heat and motion.

That is to say, the plant kingdom stores up energy supplied by the sun, and the animal kingdom dissipates it by consuming plant material as fuel, not being able to utilise the primary inorganic compounds direct.

The products of combustion are all returned in a suitable form for re-assimilation by the environing vegetation. The organic world as we know it depends for its existence and progress upon this mutually advantageous cycle, in which exchange is made continually between the synthetic activities of the plant and the analytic activities of the animal.

If vegetation were to die out, animal life would entirely cease, while if animals were to vanish vegetation would persist, but the shrinkage would be enormous, because only the very lowest forms of plant life would be able to survive. Animals, far from impoverishing their "solution," enrich it by the fertilisation and distribution of seeds. They are 
the unconscious agents of " peaceful penetration," carrying plant culture into every part of the globe. The vast, seemingly wasteful scattering of seeds and fruits, which used to be regarded as evidence of intense struggle for existence ; from the correct point of view is evidence of Nature's profusion, and a complete refutation of alleged niggardliness on her part.

In the biological sense animals are not the parasites of the plant kingdom. True parasites are distinguished for degenerate development, and gradually lose their organ of sense, means of locomotion and digestion. They are the "slave-owners" in Nature's economy, taking, but giving nothing in return for services, and their punishment is inevitable extinction. Even the carnivora serve a useful purpose in evolutionary progress, stimulating the development of activities in the herbivora and incidentally in themselves.

If carnivorous species of animals tended to increase at a greater rate than subsistence, represented by the species upon which they prey, then they would certainly die out; and if in general animals tended to increase in numbers so as to outrun subsistence, represented by herbage and foliage, the earth would inevitably become a lifeless planet. Overpopulation in the Malthusian sense is a biological impossibility: the " mother solution" of the animal kingdom is inexhaustible.

\section{Man's Capacity and his Limitation.}

What has been said with regard to the animal kingdom applies in a special way to man. The apex order of the primates, he alone within the final limits of air, water and sunshine can modify and extend his environing "solution" beyond anything imagined in the most Utopian dreams.

So far as food alone is concerned, chemistry in agricultural practice demonstrates that the most unpromising inorganic matter, as, for example, basic slag, lime, sulphate of ammonia and the nitrates, can be converted into foodstuffs under suitable conditions, so that an almost limitless population could be fed. The whole population of the world is already fed, clothed and housed by the labour of a small percentage of mankind, and it could very well con- 
tinue being so supplied with these requisites, if all the lengthy, twisted line which connects a man with his food were shortcircuited. Not only is the present efficiency extremely low, the proportion of unemployed at each end of the social scale being high, but the toiling masses are to an unrealised extent engaged in useless or harmful occupations.

The surface of the earth has only been touched in a few places, and it is, in fact, crowded with inexhaustible possibilities. The barren rivers of New Zealand were turned into an angler's paradise by the importation of a few boxes of English trout spawn. Newfoundland fishermen were provided with an abundance of flesh food by the introduction of the American hare. Following the example of Dr. Jackson in Alaska, Dr. Grenfell in 1908 took reindeer over from Finland to Labrador, which saved the Eskimos from rickets, scrofula and tubercle, because they were thus provided with milk, cream and butter. If famine can be exchanged into plenty in hard climates and in sparsely populated mountainous countries, it can be surely so in fertile lands possessing good climates and inhabited by plentiful industrious people, who have all the advantages of close intercourse and co-operation.

"Here is the difference between the animal and the man. Both the jay-hawk and man eat chickens, but the more jay-hawks, the fewer chickens, while the more men, the more chickens. Both the seal and man eat salmon, but when a seal takes a salmon there is a salmon the less, and were seals to increase past a certain point, salmon must diminish; while by placing the spawn of the salmon under favourable conditions man can so increase the number of salmon as to more than make up for all he may take, and thus, no matter how much men may increase, their increase need never outrun the supply of salmon." (Henry George.)

\section{The Indestructibility of Matter.}

Throughout vast æons of time the earth's surface has been progressively modified by the action of slow forces of upheaval and disintegration. The rocks have been crumbled under alternate expansions and contractions in the course of unnumbered diurnal and seasonable cycles, assisted by the agency of water and glacial action. 
Lands have been sunk beneath the sea, and corresponding elevations have taken place during the "breathings" of the crust, and this out of all proportion to the erosion by the oceans and rivers.

Organic life, since it made its appearance, has had an increasingly important part in the "softening" process, in preparation for and the making possible human existence. Man himself is producing not inconsiderable changes, always extending his multifarious activities.

Nevertheless, during all these changes, in which matter has been used over and over again as coin for the exchange of energy, not an atom has been added to or taken away from the surface of the globe by its denizens, plant or animal, present or past. They themselves were and are merely of the earth, presenting in their material manifestation phases in the cycle of growth, maturity and decay.

Coal, taken from the tomb of buried primeval forests, forms part of a reservoir of solar light and heat given to the earth hundreds of thousands of years ago. Untouched, unmeasured fields of it lie beneath the surface in many parts of the globe, especially in China, Russia and the United States of America. Although it may one day be consumed, it will not then be destroyed. The gases of combustion will simply be used up in the economy of Nature. The increasing vegetation which would result if the coal were all used up would replace the coal.

Civilisation and happiness are in no sense dependent ultimately upon coal or mineral oil, and the welfare of the human race will not be cataclysmically affected by their exhaustion. As well fear that the fishes may drink the sea dry, as that man may exhaust all natural resources.

\section{The Extinction of Races and Species.}

The normal extinction of a race or species is determined, when the progression by evolution in environment outruns sufficiently far the progression by evolution in heredity of the individuals composing it.

The individual bears the same relationship to the race that the cell does to the individual.

When some one or more factors are modified or eliminated in the equation of environment, to which the hereditary 
power of adaptation cannot respond, falling short ever so slightly, it is enough to upset the delicate balance between the inner constitutional productive power and the normal dissimilation of the individuals. The latter constantly gaining upon the assimilation of individuals, the whole race disappears.

Man, in common with all other species, ceteris paribus, will doubtless one day succumb, but this consummation is a remote one; nevertheless, premature dissolution of a portion of a race is not impossible, any more than that the individual may injure himself owing to evil living and bad habits.

The possession of intelligence carries with it the power of achieving great happiness if directed into right directions, but if perverted, then the misery is in inverse ratio. We see this every day in the case of individuals, but we are only just beginning to realise that communities as a whole may "live dangerously" or survive happily by learning wisdom.

It is from this point of view that we see a reasonable explanation for the alternations of civilisations. Civilisations go to pieces because there grows up some superstition which creates artificial conditions beyond the natural power of adaptation of the individuals to withstand. A great struggle for existence takes place, but if the superstition remains the culture grows in upon itself, withers away, or collapses in anarchy.

The shrinkage of population, generally assisted by agencies like the Black Death, may be so great that former populous countries may be rendered desolate. It is this fact which has given rise to the erroneous belief that a civilisation or culture is an inherent property of a race, in spite of the obvious absurdity of such a supposition. The duration of life of a race must be counted in hundreds of thousands of years, whilst civilisations have risen and decayed within the space of a few hundred years. 



\section{THE ALLEGED GRUELTY OF NATURE, THE STRUGGLE FOR EXISTENGE, AND THE LAW OF BATTLE}

\section{READER'S GUIDE}

IN Chapter IV we endeavour to show that Nature is not hostile or cruel to us, but that her appearance of cruelty is due to our seeing falsely. We do not realise that we are cruel to ourselves, and that the so-called "struggle" for existence is because we have made a hostile environment for ourselves owing to our superstition. Certain biological myths are exploded, including the belief that the sexual combat is to the death, and therefore akin to war.

\section{The Headings are:}

The "Atmosphere" of Thought and Custom-The Alleged Undue Influence of the Remote and Unseen-The Laws of Nature are Inexorable-The Indispensability of Pain -We are Living Dangerously-Palliatives are not Remedies-" Human Nature being what It is "-The Cult of Militarism-The Cult of Collectivism-What is Freedom ?-The Thin Veneer of Civilisation-The Thin Veneer of Barbarism-The "Struggle" for Existence among the Lower Animals-The Law of Battle-The Sexual Combat as a Selective Agency-Provision against Serious Injury-The Rarity of War among AnimalsWhat is War? 
We see what we know.-Goerhe.

Accuse not Nature! She hath done her part. Do thou but thine!

\section{Milton.}

On the whole, then, we conclude that the popular idea of the struggle for existence entailing misery and pain on the animal world is the very reverse of the truth. What it really brings about is the maximum of life and of the enjoyment of life with the minimum of suffering and pain.-ALFRED RUSSEL. WALLACE. 


\section{THE ALLEGED GRUELTY OF NATURE, THE STRUGGLE FOR EXISTENGE, AND THE LAW OF BATTLE}

\section{The "Atmosphere" of Thought and Custom.}

Our mental or psychic environment, resulting from the web of ordinances, institutions and beliefs within which we move as individuals, might be likened to the atmospheric envelope surrounding the earth, which is charged with moisture, often made manifest in the form of clouds and mists. These, like the fogs of superstition in our super-organic envelope, obscure our view or only enable us to obtain transient peeps at the universe without.

Even when the sky is clear, diffraction of light distorts our vision, and we may also be misled by mirage. It follows that we are thus given a false sense of proportion with regard to our more remote environment, and this it is necessary to correct in imagination by means of our reasoning powers.

Our own experience and the communicated experience of others provides the basis upon which we found our hypotheses, and these are continually tested and improved by intelligent observation upon results obtained in practice. "We see what we know."

Before astronomers are able to arrive at the truth with regard to the position and the movements of heavenly bodies, they must make corrections in the measurements obtained by their instruments, to allow for the medium through which they view these objects.

It is not less necessary, when studying other natural phenomena which concern our immediate welfare, to make keenly intelligent corrections for the distortions and obscurations caused by viewing symptoms through the biasing medium of our super-organic environment. In the Principle 
of Population controversy there is provided a lesson showing how essential it is to cultivate an imagination which can pierce mental obscurities caused by superstition.

It is easy, deceived by appearances, to blame God (people in this connection usually say Nature) for what is within the scope of our choice. Even a Huxley might exclaim, in a moment of peevishness: "I wash my hands of Nature!"

It may not seem at first a pleasant duty to forsake some favourite doctrine, apparently in accord with facts, and to have to retrace our steps after disillusionment. We may be weary, and it is disappointing to find that some path which promised a short cut led, after a baffling journey, far away from the truth we were seeking, ending in the cul-de-sac of error.

But it is better in the long run to return to first principles than to perish in an admirable though ineffective attempt to hack a way through, or as an alternative to lose oneself in a vexatious forest of circular reasoning, succumbing ingloriously to the weariness of the flesh.

\section{The Alleged Undue Influence of the Remote and Unseen.}

It was once almost universally believed that the host of heaven had discriminating influences, usually of a malignant character, upon the lives of mortals. The planets and the stars were personified and worshipped as deities, whose favour might be obtained or whose displeasure might be allayed by means of devotions, presents and sacrifices, discreetly made, so as not to arouse jealousies. The power of the gods was measured by the virulence of their supposed actions, and the priests and oracles contrived to uphold the "honour" of their patron, to see that condign calamities fell upon the impious. It was believed that wars, pestilences, famines and all things obscure in origin were attributable to the caprice of the gods.

While these beliefs may be yet held in part by the dupes of fortune-tellers, the rising sun of scientific knowledge has dispelled such mists of superstition except in dark mediæval hollows. At school our children are still taught insincerely that God is a capricious tyrant, who can be 
prevailed upon to act specially in their favour by prayer and supplication, and unless propitiated according to ecclesiastical and other rites and ceremonies, might injure them now or in the hereafter. It is of course represented that another being, Satan, carries out the punishments, but at the best they form a conception of God as a peevish elderly gentleman, who might intervene so as to spoil their innocent sport.

It is not surprising that these misconceptions persist into later life. During the Great War pastors of each belligerent country were sometimes heard to declare, to the manifest approval of their respective flocks, that their faith in the righteousness of God would vanish in the event of defeat of their country's arms. At the General Election of I9I8, immediately after the Armistice, a perfervid lady speaker referred patronisingly to " the Great Magician who waved His wand in our favour over the battle-fields of Flanders, responsive to the righteous prayers of the Allied Churches!"

\section{The Laws of Nature are Inexorable.}

The laws of Nature are eternal, universal and immutable. They are beyond our volition, and as inaccessible as the stars or the æther. Like the rays of the sun, their incidence is alike upon the just and the unjust, and we cannot turn them aside.

The Natural Law of Equity, which is based upon the social instinct, and is sometimes called the Golden Rule, i.e. Do to others as you would be done by, is as inexorable as the Law of Gravitation. The Golden Rule is sometimes regarded as an ideal line of conduct, impossible of attainment, whereas for the greater part of our lives we implicitly obey it. We rarely default, but when we do, the law of gravitation does not result in more dangerous consequences.

Natural law cannot be turned aside, the consequences cannot be evaded, and we must obey, whether conscious or unconscious of its existence. Since the Natural Law of Equity is based upon the social instinct, it is impossible to be unjust to oneself without hurting others, just as it is impossible to hurt others without ill-effects accruing to oneself. That the consequences of social maladjustments 
are not yet realised to take the form of war, pestilence and famine is simply because we have not yet learnt to trace effects back to their causes with sufficient exactness.

Nature or God has no more regard for the highest primate than the earthworm or the maggot, nor any less. All live under an equal dispensation of Justice. There is neither favouritism nor cruelty in Natural Government.

\section{The Indispensability of Pain.}

A child is taught not to fall from a height, by remembering the pains occasioned by little falls. He does not burn himself at the fire, except as the result of an accident, if he has experienced pain from the touch of objects near by. $\mathrm{He}$ acquires a capacity for happiness in proportion as he can learn discriminatingly from his own experience and the communicated experience of others.

Like causes produce like effects. Carbon burnt in an excess of oxygen does not result in the production of carbon dioxide at one time and another substance at another time. No matter how complicated the chemical action or the play of natural forces, it is always found that under like conditions there is unvarying constancy in results. We are so certain of this that when apparently we have obtained a different result we know that the conditions have been varied without its having been observed. Whether in physics, in morals, or in policies, there is the same fundamental principle of undeviating relativity between cause and effect.

Animals in free nature have their young, and do not require to receive special education as to how they should be taken care of and suckled. If we were shown the same animals neglecting their progeny, so that the cubs had to be hand-fed by a keeper, who possibly also had to guard them from the violence of their parents, should we discourse learnedly about maternal ignorance and the necessity of education for the mothers? Should we accuse Nature of cruelty?

Like causes produce like effects. Fresh air and sunshine and freedom are as necessary for the human animal as for the beasts of the field, yet how is this possible in the cellar dwellings, barrack cities, and in the ill-smelling, 
poisonous atmosphere of the noisome tenement slums, where the blessings of sun and rain are alike a curse, and where there is a denial of all natural regeneration by vegetation?

The doctrinaires of maternal ignorance do not imagine the plight into which educated mothers of the cultured classes might fall if they were deprived of their "keepers," the trained nurses, and placed under the same conditions as their slum sisters. With all their education, mothers of the "upper classes," living in a cage of gold, hemmed in by oppressive conventions, frequently exhibit symptoms of the same maternal aberration. Obviously, infant neglect and high mortality in child-life are not due either to education or lack of education, to civilisation or barbarism of the mothers.

Just as we use our common-sense in our observations of captive animals, and diagnose that captivity has warped their instinct or intelligence, so, when we see similar abnormal behaviour in humanity, we ask ourselves, Is humanity free ?

Doctors are concerned because there is an increasing proportion of young women who are unfitted for healthy motherhood. In a medical census taken at Wood Green recently (I9I7), in the London district, of 2,I85 children, only 673 were normal in all respects. At the outbreak of war, and during the course of the war, the medical examination revealed a lamentable and almost unbelievable proportion of unfits in the total "man power" of the nation. The average duration of life is low, and the prevalence of venereal disease, "the race poison," is more than serious. Comparisons between the average measurements of the structural bones of the present-day Englishman and those of his ancestors show a distinct tendency towards degeneration, especially as regards the facial bones. Caries and pyorrhœa are familiar diseases and persons with a whole set of good teeth are rare.

These unpleasant symptoms are not due to the fact that Nature is hostile or cruel, for how can Nature be cruel to herself? We are part of Nature.

That we feel unduly uncomfortable owing to the changes of the seasons, and are often successfully attacked by epidemics like influenza, means simply that we have defaced 
our environment beyond our inherited constitutional power of adaptation. Man is a gregarious animal, fond of the society of his fellows, but this fact does not explain, on the one hand, the overpopulation of the towns and cities, densely piled with humanity, often 500 or 600 to the acre, and on the other hand the depopulation of the country-side. Within the environment in which the majority are forced to live, the rarity of human beauty and grace is no surprising concomitant, and it is certainly such that the healthiest and most alert cannot hope to survive generation after generation.

Pain is indispensable, for unless we suffer pain, how otherwise can we realise that we are proceeding in a wrong direction? It is through pain that we learn wisdom, and we must learn or perish.

\section{We are Living Dangerously.}

In our artificially manufactured hostile environment, self-sacrifice by unnatural fasting, celibacy, unprotesting acquiescence in injustice, and other forms of the mortification of the flesh, are as unavailing as gluttony, sexual excess or physical and moral violence.

That the votaries of each extreme meet in agreement by attributing their misfortunes to dæmons or evil spirits or to Nature's cruelty when their conduct is met by its inevitable consequences, is no indictment of Nature or God. That they obstinately proceed under the influence of this mood into greater extremes of folly, thinking that safety can be secured by "living dangerously," only shows they are slow to learn in their befogged psychic state.

We find pleasure in accepting the risks which, by progression in evolution throughout millions of years of adaptation, we are fitted to face. It would be evidence of deranged nerves if the proximity of the sea, a river, or a precipice were considered by one to be hostility in Nature. Just as healthy and sane people enjoy boating, swimming or climbing, so the elegant musk-deer delights in its carnivorous environment of the African veldt, because happiness is ensured by natural adaptation. It regards the lion from the same point of view as we do our topographical surroundings, i.e., as a feature of interest, but it does not live dangerously. 
If we allow our senses and intelligence to be dwarfed or obscured by superstition, if we shut our eyes and in blind vanity disregard the plentiful warnings-the danger signals against the retention of social institutions which are not standing the test of time-then in the fog engendered by the assumption that all is well, Nature may appear hostile as we persist in wrong directions, hurting ourselves in doing so. Do we see here a possible explanation for the otherwise mysterious and increasing prevalence of hysteria, neurasthenia and other nervous disorders?

Doctors are not able to cure these or any other diseases; they may only palliate them. By ensuring that the patient is placed under favourable conditions for recovery they "assist Nature." This is an admission that Nature is the healer, and that we bring about disease and misery through our transgression of the laws of Nature. Ignorance of these laws does not preserve us from the consequences of folly, and man must liberate his intelligence from the fogs of superstition, allowing it to guide him as instinct guides the dumb creation of freedom.

It is no longer thought by enlightened medical men that there is really hereditary transmission of disease. The seed being a single cell, it could not survive if it were tuberculous or syphilitic. In such cases as when a child is born diseased, the disease has been brought about at an advanced stage in its pre-natal environment. When the parents live dangerously, the consequences are cumulative until the race ceases to transgress.

\section{Palliatives are not Remedies.}

Just as in a besieged city, until the citizens are freed, organised rationing is preferable to disorganised famine, so, while we are alienated from healthy surroundings owing to our superstition, it is good to care for unfortunate children suffering from "gaol" fever and "English" disease, and to provide free medical attention, clinics and communal crèches.

It is well to treat by the Salvarsan method those suffering from venereal disease, to assist congenitally weak eyesight with spectacles, to replace decayed teeth with dentures, to have mental hospitals, workhouses and national alms- 
houses. But if we regard these provisions as absolute remedies, we shall be shocked to find that, instead of curing our present evils, we have only built up a bank of consequences for a more evil future.

\section{"Human Nature being what It is."}

It preserves our reason to link up cause and effect. In China there is a delusion that neighbourhood is possessed of good or evil luck, determined by the quality of "Fengshi" residing in burial-places.

In some parts of the East it is the custom for the rescuer of anyone who has fallen into a river, or who tries to drown himself, to be condemned to keep the rescued person for life, as it is believed that the river spirit has been deprived of sacrifice and evil may come of it. In Britain, not long ago, occult hostility took the form of a belief in the Evil Eye and in witches, just as at the present time Fabian intellectuals and Anglican Deans speak of the niggardliness of Nature in advocating compulsory checks to population.

How often, in justifying more interference with the lives of other people, whose turbulence increases in proportion as their liberties are curtailed, do we hear our lawmakers begin a wise-sounding statement with the words: "Human nature being what it is "-an innuendo they would resent indignantly if all that it implies were directed against their personal characters as "respectable" people. It is their belief that human nature is inherently wicked (how they could possibly discover this, if it were so, is never explained, nor can it be), that it must be kept in check by "firm" government, and that it is this interference which renders civilisation possible.

To believe that our Mother Earth or our Human Nature is inadequate is just as unreasonable as to fancy that it is because of education, culture, civilisation or the lack thereof that there is hell upon earth.

Religion, education, culture and all the things that go to make a real civilisation would not disappear, would not cease, but increase and progress if we made a return to conformity with the Natural Law of Equity and built upon a just basis. There is no mystery about it : cruel poverty, 
painful disease and murderous battle are within the scope of our choice.

\section{The Cult of Militarism.}

Oriental attitudes of mind are not confined to the Orient. In the Occident fatalism has not reached the pitch where a fellow-creature would be left to his fate were he struggling for life in deep water. Yet so used have we become to the spectacle of neighbours of every class of society struggling for existence in a hostile environment, made not so by Nature or God but by our stupid choosing, that the psychological effect upon darkened intelligence has been to induce a strong belief in a sacred struggle not merely for existence, but for supremacy, tending to the improvement of the human race through the survival of the fittest.

It was characteristic of the militant evolutionists, who flourished so exceedingly before the Great War, to affirm that only a few prizes were awarded by Nature, and that the great majority of necessity drew blanks in the "gamble" of life. Deceitful appearances in human affairs favoured their views that Nature was a niggardly hag, " red in tooth and claw," whose treasures must be fought for -by her scrambling children. The winners in the struggle, so it seemed, were selected in a simple process of elimination by means of the "elemental" agencies of cunning, knockout blows, rape and murder. This crude hypothesis has been summed up in the well-known expression: "Get on or get under."

The warlords and professors of this theory regarded with complacency the condemnation of millions to penal servitude for life in barracks and in cheerless poverty. This dispensation was necessary, because how was it otherwise possible for the fortunate leisured few to wrest from miserly Nature her carefully guarded secrets?

They pointed to the degrading poverty which everywhere existed as irrefutable evidence that all would sink to the condition of the lowest unless, as they contended, power were given for the legalised exploitation of the scrambling masses. Even poverty itself was not an unmitigated curse -at any rate for the poor! Was it not true that poverty was a great incentive to effort, often productive of genius ? 
Was not necessity the mother of invention, so why question a system so eminently beneficial that man scored over Nature in any event?

So, arguing from false premises, imagining that they could "take in God," the professors asserted that until power was acquired and used within the State no nation could become great and be enabled to assert itself in dominion over other nations, thus growing prosperous in exploiting them. It was a sacred duty, therefore, to employ moral and physical violence, even to the point of murder, if it were necessary, in the process of efficiently organising the nation.

"Political and human rights have nothing to do with each other," said the imperialists, who desired the bondage of compulsory military service imposed upon their fellows. In Germany especially it was taught in the schools, churches and universities that individuals belonged to the State, which was deified as a god, with the Kaiser as its personification. A slavish obedience to military authority was enjoined as the first duty of man, and the Kaiser publicly proclaimed that a soldier must be ready to kill even his own father or brother if ordered to do so by a superior officer.

The lesson of the Great War has proved the cult of militarism to be a doctrine of vanity, yet militarism has been preached more than ever among the nations which were supposed to have won the war. Militarists learn nothing from experience.

\section{The Cult of Collectivism.}

It is curious that those who imagined themselves to be in opposition to the imperialists also fell down and worshipped the same false god, sometimes called the State, sometimes the Majority. While condemning military conscription, many persons professing to be Socialists (which apparently means anything) demanded powerful State interference and " co-operation " by force in almost every other direction. One of these conscientious objectors declared: "The State can be whatever you make it, so can Liberty!"

But can it? If the militarists or imperialists who believe in the Rule of Force and who have conscientious objections to Peace by Negotiation are wrong, so also are 
the State-Socialists who believe in Majority Rule or Bolshevism.

One may look through the highest-powered magnifying glass and yet fail to see any essential difference between the ideal State of the militant-imperialist and of the StateSocialist. Though they both frequently speak of Liberty, there is a mental reservation that "it can be whatever you make it!" It is not surprising that the ideals of the Socialists, like those of the so-called Christians of each belligerent country, crumbled into fragments at the first stroke of war. They had been worshipping images.

\section{What is Freedom ?}

Let us pause for a moment to get a clear vision of what is meant by Liberty.

In applied physics there is what is known as a "perfect" engine. It is an ideal engine of maximum efficiency, wherein all the conditions laid down by the laws of Nature are completely complied with, losses due to friction and so forth being reduced to an irreducible minimum. Similarly we may imagine in applied sociology an ideal State. It is obvious that the approximation to such a state of perfection is not reached by establishing institutions which take away the freedom of the constituents.

Yet the imperialists and the State-Socialists, each in their own way, propose as their ideal State one in which there are a few privileged individuals and glorified slavery for the masses. It is not that they do not desire freedom-indeed, they complain bitterly of the consequences of their own acts. But they do not realise that they are reaping their own harvest, and so attribute shortcomings to particular persons in power.

How, then, is Liberty approached? It is not licence, and it is not compulsory service. It is only attained when social institutions are in accordance with Natural Discipline, which must be obeyed, and which is comprehended in the statement: Do not unto others what you would not have done to yourself. Social institutions must be founded upon justice-upon equality of opportunity for all.

The question really is, where have we gone astray? We have gone astray, creating a hostile environment for 
ourselves, and failing to link up cause and effect, we allege that Nature is cruel. People have been known to ask, "Can we forgive God?" and theologians babble of "original sin." Scientists and high-browed politicians try to impress their hearers by alluding to " the blind forces of Nature." They do not realise it is they who are blind!

Failure to take the bandage from their eyes has caused the keenest inquirers after truth to come to wholly illogical conclusions about certain natural phenomena, upon which errors lesser minds have made haste to erect a tissue of falsehood. "No personal habit more surely degrades the conscience and the intellect than blind and unhesitating obedience to unlimited authority." (Huxley.)

Darwin, Wallace, Lyell and other competent contributors to the evolutionary theory have doubtless erred in minor respects, but it must be left to the imagination to picture what would occur if their works were lost, and there only remained the false doctrines of the militant evolutionists.

\section{The Thin Veneer of Givilisation.}

A belief in a Nature angular and spare-framed went appropriately with that held by the theologians, that man was naturally vicious, greedy and faithless, endowed with a mind which could only be disciplined by the wholesome fear of hell-fires. Like the professors, they welcomed every new accession of power to the State which would restrain " the unspeakable passions and lower instincts inherent in human nature, sacrificing them to the service of civilised progress."

The doctrine of " original sin " received reciprocal support from the professors, who drew artful conclusions from impressionable childhood, spoilt and savaged by the influence of "Prussian Militarist" nurses and mentors. Their Sadducean imagination delighted in the invention of murderous characters for prehistoric man.

It was variously credited that when not " hunger marching " our remote ancestors were in a state of continual unrest, owing to the insufficient food supply. In those times of "club rule," according to the romantic professors, the strongest arm and the thickest skull survived, accompanied by the persistence of a cunning intelligence, which at length differentiated with, and placed a limit upon, the bony 
structure progress of the cranium. Such was their fantastic conception of Natural Selection.

It was supposed that Sexual Selection in evolution was accomplished by equally crude and violent means. The competitors for the favour of the Palæolithic maiden fought a battle which invariably had a fatal termination!

But the selection, being a shrew, had to be wooed suitably. She did not submit at once to the most successful exponent of frightfulness. Nevertheless, the ubiquitous club speedily eliminated any lingering coyness. She was dragged insensible by the hair to the nuptial cave, and upon recovery became slavishly devoted to her ferocious lover!

Thus the militant evolutionists, whose first-hand knowledge of natural history appeared to have been taken from the captive life of lower animals or of humanity in the squalid slum and court, proved to their own satisfaction that the cultured inhabitants of Europe and America are the descendants of ancient races of hooligans, who preserved themselves by killing and eating each other!

They opined that the "cultivated races" had gradually acquired, and transmitted by inheritance, superior characters, which revealed themselves in later life after the wild oats of youth had been sown, this tendency being most apparent among the cultured classes. They jumped to the conclusion that the cultured man was necessarily a just man. They assumed quite gratuitously that men and women inevitably became more righteous as they got older. The senile professors were unable to differentiate between the childish and the childlike!

They imagined that they were unanswerable when they stated that "the thin veneer of civilisation" was manifest in the greater personal and social value put upon life, and that the "cultivated races," being too civilised to fight, were the natural custodians of the "inferior" races, who could not be trusted to govern themselves.

The God-Nature answered them completely by the Great War.

\section{The Thin Veneer of Barbarism.}

So as to square with their doctrine that cultivated man had, to some extent at least, tamed "hostile" Nature, the 
professors represented the struggle for existence to be fiercer among savages, and proportionately more intense among the lower creation.

Those who know the facts are in a position to affirm that when the savage is poor, the reasons for it may be found in similar conditions to those producing the civilised struggle for existence.

Certain savages may eat with relish the worms found in rotten wood, others may devour grasshoppers, but Englishmen prefer game that is high, cheese that is maggoty, while Frenchmen eat snails and the legs of frogs. These tastes are no criterion of measure in indigence.

That some savage tribes destroy the sick and the aged and that they practise infanticide is not proof of greater struggle. Are not similar practices common among communities which boast of their civilisation? A cultured society is not inevitably a humane one. Humanity and justice synchronise with free institutions and custom, and their opposites, that is, inhumanity and injustice, are the accompaniments of slavish ideals.

Slow methods of killing the weak and helpless are not less cruel than quick dispatch, and in recommending the latter method for inconvenient paupers and manufactured criminals, the militant professors prove that their feelings of humanity are at any rate as highly developed as those of the savage. In this they collided for once with their friends the bishops, who reminded them that "It was the inscrutable will of the Lord, "The poor ye have always with you,' and He made some poor and some rich, that the latter should manifest their charity towards the former." (Bishop of Salisbury in a sermon.)

When prisoners have been confined in a dungeon without food, it has been known for them to lose their reason and prey upon each other. When sailors have been cast adrift and have become insane from hunger and thirst, they have sometimes devoured comrades. In times of protracted sieges during war, cases are recorded in which starved civilians have crazily consumed their own children. There is, however, no fear that such might become a perpetual habit with the captives when they recovered their freedom and mestal balance. 
Although the custom of cannibalism is frequently found, or at one time existed in locations where cereals, fruit and other things are naturally provided in overflowing abundance, the dismal evolutionists believed it to have its origin in the chronic poverty of the natives. More competent observers, however, have pointed to a different reason for its origin, namely, superstition or mind-imprisonment.

The Sandwich Islanders did honour to their good chiefs by eating their bodies, but their bad and tyrannical chiefs they would not touch. Savage warriors have feasted upon the enemy slain and prisoners, under the delusion that the latter's fighting vigour was thereby added to their own. In eating a missionary or other superior being, the superstitious heathen imagined that in this way he would become endowed with the white man's cunning.

The veneer of barbarism is no thicker than the thin veneer of civilisation. It is not many hundred years ago that the priests or witch-doctors of our ancestors officiated at ghoulish ceremonies in which the ignorant and awed devotees drank the blood and ate the flesh of human sacrifices.

True religion is mental and intellectual freedom.

\section{The "Struggle" for Existence among the Lower Animals.}

In order to explain why there were no evidences of interminable want among the lower animals, it was asserted by the pretentious professors that the population was checked owing to the fact that the animals ate each other up. They were of opinion that the old and stricken were weeded out by beasts of prey, which were themselves cannibals.

According to this theory, animals living a natural life never died of old age, but were feasted upon by their comrades to save burial expenses!

There was once a man, it is said, who believed that donkeys are immortal because he had never seen a dead one!

It requires a practised eye to pick out the aged wild animal, which, living a clean and healthy life in its natural environment, does not become decrepit, and which, when nearing the end, finds some secluded spot where he may sleep away. After death he is rapidly hidden by the carrion animals, burying beetles and vegetation. 
It is not the old and tough cattle that are sought for food by the carnivora, but rather the young ones, which have to be taken by stealth when the parent animals are off their guard. Old bulls which have left the herd, living a quiet and lonely life, are quite able to take care of themselves, as hunters well know.

As for the preying beasts, it is contrary to the instinct of self-preservation, which they have in common with all species, for them to prey upon animals of their own species. The truth as to this is expressed in the saying "Dog does not eat dog." If he does, it is in error.

No ignorant barbarian can pervert the truth like the arm-chair naturalist, whose unfortunate propensity should be accompanied by a longer memory. At one time he asks his readers to believe that animals in free nature invariably die young, and at another time that in captivity they also die young, which happens to be true, but not for the reason he gives. The following, as an extreme example, is taken from an article in the London Daily Mail (January 27, I920), in which it is stated that wild animals die prematurely in captivity because they are too happy to live:

"The arteries harden and the heart degenerates just as in man, but years before the proper time. You take a wild animal, feed him, keep him warm and dry, and remove the fear of enemies. The animal then becomes perfectly happy -far happier than in a state of nature, for the fear of death, lurking in every tree branch or in every patch of tall grass, has disappeared. A sort of beatific lethargy follows, however, which causes an unnatural 'natural death." "

So painfully nervous must the wild animals be "in a state of nature," it is surprising that they do not drop down from heart-failure when "the dread of death" comes out of its hiding-place!

\section{The Law of Battle.}

In the preface to the second edition of The Descent of Man, Darwin wrote: "My conviction of the power of sexual selection remains unshaken, but it is probable, or almost certain, that several of my conclusions will hereafter be found erroneous." 
The fabric of superstition erected by the militant evolutionists cannot be altogether accounted for as an extension of error perpetrated by the Darwinists, although it cannot be gainsaid that they were influenced by Darwin's tendency to overrate the severity of the competition in sexual selection. This tendency was due to the continual search of Darwin, owing to his unfortunate Malthusian bias, for amputative checks to population. The theory, as a matter of fact, is unintelligible, if the assumption is made that where a physical battle takes place between the competing males, which of course are of the same species, it is one to the death.

In boxing or wrestling bouts, which are survivals of the sexual combat in the case of man, the competitor who loses his temper and becomes violent usually gets the worst of it. Any ignorant spectator who believed that the contestants desired to take each other's lives would be said by polite people to be deceived by appearances. It is true that a fatality as the result of a mischance has been known to happen, but this may take place in any game, and no one would be more distressed than the unlucky combatant who had been the cause of the accident.

We smile tolerantly if we hear that our son at school has had a fight, and so long as he fights fairly with his fists a boy of his own size, we are indifferent as to the result, which is always beneficial and regulative. Boys after a fight usually become fast friends.

It is, however, different if he employs weapons like stones, sticks and booted feet. This we regard as a serious fault, and the solicitude we feel is instinctive. The boy is living dangerously, and we are concerned about his preservation.

\section{The Sexual Combat as a Selective Agency.}

The biological purpose of the test is to ensure that the most healthy, alert and progressive males at any given time are chosen for race propagation, thus ensuring that the species is preserved and improved. In the cases in which the test by combat takes place, it is a fair and just one of skill, strength, endurance and temper, governed by instincts as regulative as the Queensberry rules in boxing. There is equality of opportunity for all competitors. 
Accidents in the rough sport owing to a false slip may occur even to the fittest animal. There may be a broken limb and a fatal termination, but these have no bearing upon evolutionary progression, because they cancel each other out. The immature animal is not killed, but only pushed to one side until he gains the full prestige of maturity and is entitled to " a place in the sun."

There being no object in the destruction of the older and defeated animal, his life is preserved also. He gives place gracefully, and occasionally leaves the herd or school, henceforth to rusticate on the mellow side of loneliness or to rejoin after the season.

The species cannot be preserved unless the individuals are, and the merest reflection is enough to convince one that the survival of either is impossible, were the combat to the death.

The severity of the contest varies a good deal. In many cases the selection is determined apparently by spontaneous preference. Instances are known, among birds and mammals that engage in fighting for the possession of the female, in which the competitors have been left fighting while the female unobserved took her departure with a third suitor.

There are many species where there is no battle, but the males seek to captivate the opposite sex by exhibiting their personal attractions in beauty of plumage, fur, form, colour, voice and so forth. Sometimes the males dance and spar round each other, and in certain cases, as, for example, the penguins, the competitive love-making is a pretty display of fine manners and politeness.

\section{Provision against Serious Injury.}

Where animals engage in more or less severe duels, provision is made against serious or fatal injury. This provision appears to have been evolved parallel with the development of the weapon. Sometimes it takes the form of a shield, and sometimes the weapon itself, while effective as a defence against the attacks of preying beasts, is rendered ineffective for the infliction of serious injury to males of the same species.

Although wild boars fight desperately, the blows fall on each other's tusks, or on a layer of gristly skin covering 
the shoulder, called the shield. In old age the boar is handicapped owing to the tusks becoming curved up and inwards.

Stallions attack each other in the neck with their teeth when fighting, and so do male seals and the baboons of the Cape of Good Hope. In each case they are protected by very thick manes. Many carnivorous animals are similarly protected, while others have tough loose skin round the neck.

Among combative cattle the bull's horns are placed at such an angle that in butting against each other the points are out of danger. In some varieties the horns are very short, not like the cow's, which are intended for serious work in defending her young against the attacks of wolves and other predatory creatures.

The fiercer the contest, the more handicapped are the belligerents. Deer, especially the red-deer, are notoriously combative, but while their antlers form a good defence against carnivora, they are futile as lethal weapons against each other. ${ }^{I}$

Let two persons arm themselves each with the gnarled branch of a tree and fight a mock combat in the manner of the stags. They will find it enjoyably funny, and they will wonder what Darwin meant in contending that the stag's antlers, while not so dangerous as single points, are well adapted for fighting with rivals possessing similar weapons. It was simply ludicrous for Darwin to write of stags " bellowing a challenge to mortal combat," as though after the rutting season one might expect to find the moors strewn with corpses! The fiercest battle is really an innocent affair.

The horns of other ruminants are all prevented in some way from inflicting grave injury upon comrades. The springbok has horns bent at right angles, with the points inwards and towards each other. Other antelopes have long curved horns bent backwards so far that they reach almost beyond the middle of the back. The horns of rams

I Accidents with a fatal termination, equivalent to manslaughter or accidental death, do take place. It sometimes happens that the horns of duelling stags or male elks become inextricably interlocked, so that both competitors perish. Here is a biological comment upon the folly of competitive armaments ! 
are spiral, and the lyrated horns of the antelope, Strepsiceros $k u d u$, are right and left-hand helices. The horns of the moose extend five and a half feet apart at the tips, and against rivals similarly armed they are quite harmless.

\section{The Rarity of War among Animals.}

In their haste to demonstrate that all nature is at war, the professors with the bloodshot eyes see war where there is none. It is not surprising, since real war among the lower animals is a rarity, that they have not looked for it in the direction in which it is to be found.

Darwin gave a useful clue when, in describing some amazing customs among savages, he wrote: "These miserable and indirect consequences of our highest faculties may be compared with the incidental and occasional mistakes of the instincts of the lower animals."

\section{What is War ?}

In that violent strife between members of the same species which we call war, fighting to the death is intentional, both sexes take part, irrespective of age, all individuals suffer, and the fittest do not tend to be preserved. 


\section{CHAPTER V}

\section{RUDIMENTARY WAR}

\section{READER'S GUIDE}

CHAPTER V describes rudimentary war, and demonstrates that war is a blunder or aberration of instinct or intelligence.

\section{The Headings ARE :}

The Rarity of War among the Animals-The AtrocityExamples of the Atrocity-Many Naturalists, including Darwin, Puzzled to Account for the Atrocity.-The Atrocity not confined to the Herbivora-The Atrocity not based upon Instinct but the Aberration of an InstinctInstincts are not Infallible-Mistaken Actions motived by False Stimuli-Physical Captivity or Mental Delusion the Necessary Condition for the Atrocity-An Interesting Experiment-The Resentment generated under Captivity - Captivity is Abnormal-In Confinement all Natural Habits are perverted-The Hostile Environment of Captivity-The Key to the Problem of the Origin of War-The Factors composing the Equation "War." 
Walt Whitman has said :

I think I could turn and live with animals, they are so placid and self-contained.

I stand and look at them long and long.

They do not sweat and whine about their condition.

They do not lie awake in the dark and weep for their sins.

They do not make me sick deciding their duty to God.

Not one is dissatisfied, not one is demented with the mania of owning things.

Not one kneels to another, or to his kind that lived thousands of years ago.

Not one is respectable or unhappy over the whole earth.

But we should note this: Whitman merely wanted to live with the animals, he did not desire to become one. He was not willing to forfeit knowledge: and a part of that knowledge was, that man has some things yet to learn from the brute.-ELBERT HUBBARD. 


\section{CHAPTER V}

\section{RUDIMENTARY WAR}

\section{The Rarity of War among the Animals.}

The stories of monkey warriors, engaging each other in human-like warfare, may be dismissed as the mythical tales of romantic travellers. All such stories are of the same category as those of the ghosts and hobgoblins invented to thrill the immature imagination.

The considerations set forth in Chapter IV have led many naturalists to doubt if war has existence among the Vertebrata sub-kingdom of animals, save among the sons of Adam. Among the insect communities of wasps, bees, ants and termites, something very like organised warfare does take place occasionally. For example, when there has been an exceptionally bad summer, bees will make predatory raids upon neighbouring hives, and in similar circumstances ants have also robbed their neighbours.

It is significant that these latter are property-owning animals, and the raids take place when all, raiders and raided alike, are short of supplies. The importance of this fact will become more prominent as we advance in our study of war and its origin. It is not that the economic factor lies at the root of human strife, but that this factor is an early intermediate cause of organised warfare.

Although there are points of resemblance between insect communities and human societies, the differences are very real, and it may be unwise to speculate prematurely upon the habits of animals so widely different from ourselves.

We may be sure that in so far as war does exist among the higher animals, other than man, it is of rare occurrence and not easily recognised at once as war. 


\section{The Atrocity.}

Cattle that are at all combative in disposition will attack violently, and often fatally, a distressed member of their own herd which, owing to some accident, in great danger, or in momentary pain, struggles and cries for help.

The victim may be in perfect health and unwounded, and the phenomenon should not be confused with the treatment accorded to a sick and weak member, which is not pursued to a fatal end, and has for its purpose the preservation of the general health of the herd-Nature's plan of isolation for diseased animals, which after recovery rejoin the healthy and vigorous, again to take part in their rough games. This instinct of quarantine has its use, but the atrocity we have under observation cannot be said to have any obvious purpose.

\section{Examples of the Atrocity.}

Mr. W. H. Hudson, the eminent naturalist, who made a study of the nature and reason for this strange behaviour, tells how, when a small boy, he witnessed such a tragedy.

A little distance from the farm, while playing among the roots of some trees, he saw gathered on the bare level ground some domestic cattle just returned from pasture. In a vivid manner he thus describes what took place: "Hearing a great commotion among them, I climbed on to one of the high exposed roots, and looking over, I saw a cow on the ground, apparently unable to rise. She was moaning and bellowing in a distressed way, when suddenly a number of her excited companions crowded round and proceeded to gore her. I remember that I was very much frightened at what I saw, and that I ran home as fast as I could."

The naturalist also referred to a personal experience which greatly impressed the late Mr. Andrew Lang, who saw a similar incident take place among a herd of cattle in Scotland. One of them had got wedged between two rocks, and was struggling with distressed bellowings to free itself, when the others turned with sudden amazing fury upon the unfortunate beast and gored it to death.

Felix de Azara records a rather cruel experiment on the temper of some tame rats confined in a cage. The owner caught the tail of one of them through a crack and began 
sharply pinching it. Its cries of distress and struggles to free itself greatly'excited its fellow-prisoners. After rushing wildly round for some moments, they flew at their companion, fixed their teeth in its throat, and quickly dispatched it.

For the purpose of capturing rats in a farm, boards painted thickly with a suitable adhesive varnish are sometimes laid on the runs from their holes. Rats are unable to escape when their feet and tail become stuck to the board. It sometimes happens that two rats are captured side by side, and when this does take place, they invariably fight savagely with their teeth until one kills the other.

\section{Many Naturalists, including Darwin, puzzled to Account for the Atrocity.}

Darwin, who knew how animals possessing the social instinct assist each other, and who describes how an elephant, after escaping from a pit, also helped its companion to escape, was astonished to note that upon a certain occasion some elephants attacked a fellow caught in a trap, from which it was struggling to free itself.

In his Essay on Instinct he could not ascribe any satisfactory reason for this cruel behaviour. In The Descent of Man he refers to it, and says: "This is almost the blackest fact in natural history, unless, indeed, the explanation which has been suggested is true, that their instinct or reason leads them to expel an injured companion, lest beasts of prey, including man, should be tempted to follow the troop."

After observing that such conduct is not much worse than some barbarian customs among savages, Darwin dismisses the subject, and goes on to give instances illustrating how animals show love and sympathy for each other in danger, old age and sickness.

The hint that the atrocity might in certain circumstances be useful was extended into a current belief among naturalists that it was based upon true instinct. They readily confused it with the instinct of quarantine, and Dr. Romanes, for example, remarks: "We may readily imagine that the instinct displayed by many herbivorous animals of goring sick and wounded companions is really of use in countries where the presence of weak members in a herd is a source of danger to the herd from the prevalence of wild beasts." 
Here it is erroneously assumed that the sick are set upon and killed, which is not a fact. Sickness and decay from age or other cause imperceptibly increase, so that the sight of a dropping member grows familiar to the herd, as does that of an individual possessing some malformation or unusual colour, as in the case of an albino.

The individual attacked in the abnormal way we have described is as often as not in perfect health and vigour, and may even be unwounded. It is of the same species as the attackers, and it may be of either sex and of any age.

\section{The Atrocity not confined to the Herbivora.}

It is perhaps necessary that we should correct any possible impression that it is only among the herbivora that the useless killing of a perfectly healthy individual takes place at these casual times.

It is the instinct of wolves to devour the creature they overcome and kill. When a pack of starving wolves pursue the ponies drawing a sleigh, if a passenger shoots and wounds one of them, so that it yelps and rolls upon the ground, the others sometimes attack and consume it, in the belief, presumably, that it is one of the ponies. This has given rise to the myth that wolves and other preying beasts are cannibalistic.

A similar mistake is sometimes made by jaguars, for if a jaguar captures a peccary out of a drove and does not instantly escape with his prize into a tree, he runs a risk of being attacked, slain, and then eaten by his fellows, even to the skin and bones.

In no other ordinary circumstances, even when famished, will predatory animals devour their own species, such action being contrary to the instinct of self-preservation.

\section{The Atrocity not based upon Instinct, but the Aberra- tion of an Instinct.}

The explanation given by Mr. Hudson is without doubt the correct one, He regards the atrocity as not based upon an instinct proper, but the aberration of an instinct, a blunder into which animals sometimes fall when excited to action in unusual circumstances. 
When the individuals of a herd, school or family are excited to a sudden mad rage by the distressed cries of one of their fellows, the sight of its bleeding wounds, the smell of its blood, or when they see it frantically struggling on the ground in violent pain, or imprisoned in the cleft of a tree or rock as if in the clutches of a powerful enemy, they do not turn upon it to kill, but to rescue it.

The illusion creates the same emotion which they experience when attacked by a real enemy of a different species. The excitement must be discharged, and in the absence of a real enemy, the victim is fallen upon in error and slain.

\section{Instincts are not Infallible.}

Instincts are very constant, but are not infallible, and the case of the late visitation of Pallas's sand-grouse some years ago is an illustration of how even the wonderfully reliable migratory instinct in birds can err upon rare occasions.

Owing to some unusual atmospheric condition or combination of unknown circumstances, the sand-grouse deviated widely from their ordinary route, and scattered themselves in thousands over the continent of Europe, to perish miserably in strange lands unsuited to their constitution.

\section{Mistaken Actions motived by False Stimuli.}

Animals acting instinctively, as well as men acting intelligently, have at times their delusions and see things falsely, and are moved to action by a false stimulus to their own disadvantage.

A simple experiment may be made by anyone upon a few dogs for the purpose of illustrating how illusion can lead to violent action, ludicrous, rather than painful, to witness.

Let the dogs be encouraged by cries and gestures to expect that some animal they are accustomed to hunt is about to be unearthed and overtaken. If, when they are urged to attack, a rough dummy is cunningly exhibited, the dogs will seize, worry and tear it to pieces without the faintest suspicion of its real composition.

Dogs and monkeys, possessing considerable reasoning powers, accustomed to select leaders and co-operate in 
packs and troops for the purpose of actively assisting each other, behave remarkably like humankind when they are irritated by something which does not afford immediate explanation. There is a tendency, when one of the pack cries out in pain, no man being in sight and no cause apparent, for the animals near to blame each other.

Here the exciting irritation-the cry for help-is not strong enough to produce the illusion which results in a fatal attack upon the victim or a general mêlée in the kennel, but each dog mistakenly thinks the other inflicted the injury. His impulse is to take the part of his injured companion, and if the cry for help, caused perhaps by a sudden cramp or the prick of a thorn, is not very sharp or intense, the other dogs will not attack, but merely look and growl at each other in a suspicious way.

\section{Physical Captivity or Mental Delusion the Necessary Condition for the Atrocity.}

Since the injury or destruction of a perfectly normal individual is of no advantage to the race, and since the excitement must be discharged, it may be asked why the animals do not attack the instrument which restrains their freedom. Why, for example, did not the rats attack the cage they were shut in, and bite at the woodwork and wires? Why were not the imprisoning rocks attacked by the Highland cattle?

Before we attempt an explanation, it is important to note that physical captivity, leading to derangement of instinct, is in every case a necessary condition for the atrocity. The captivity includes the restraint of sudden illness or abnormal accident, for which there is no provision in the web of reason or instinct of the animals. If the pinching hand had been visible to the rats in the cage, the bites would undoubtedly have been inflicted upon it instead of their unfortunate comrade.

\section{An Interesting Experiment.}

Psychologists sometimes quote the following experiment to show how slowly an imprisoned animal learns to release itself unaided, although the means of release are prominently provided. 
An animal, say a cat, is enclosed in a cage, which has a large catch or trigger inside, a touch upon which will cause the sides of the cage to fall apart, giving liberty to the prisoner.

It is truly wonderful how long the cat will search everywhere for a means of escape without doing the one thing necessary.

There is only one desire in its mind-to get out-but the only way to which it has been accustomed is by means of some opening by which presumably it entered. This has no existence.

It appears to the spectator as though the cat avoided the trigger carefully. It almost seems to be an object of instinctive dislike. Finally, it may be by accident, the imprisoned cat touches the catch and is free.

Let the experiment be repeated several times, and it will be found after a while that the cat becomes "wise" to the trick. At this stage it is necessary to devise a new invention if the cat is to be made a prisoner for any length of time. It is possible, moreover, by the exercise of much patience to train the cat to search for the trigger.

\section{The Resentment generated under Captivity.}

Anyone with experience of dogs knows that a normally well-disposed animal becomes very fierce when it is tied or chained up, but he rarely appears to notice the restraining instrument, unless it is touched by someone. The prisoner "hugs his chain" in the most literal way, and nothing enrages him more than interference of this kind.

The caged or chained-up housedog appears to blame anything endowed with movement or sound for his misery, and he will attack any living creature within reach when captivity has brought about temporary insanity and he sees enemies everywhere. If a dog " sees red" there is even danger in unexpected liberation. He may bite the first person he meets, who may be his own master.

\section{Captivity is Abnormal.}

The chain or cage is not usually attacked, although the chain or door of the cage may be rushed at if they are seen to move; and the reason why they are disregarded would 
appear to be that complete imprisonment or enclosure, from which there is no possible escape, is incredible to the unsophisticated animal mind. Wild animals are adapted for a normal environment, and their inherited web of instincts normally does not include provision for unlooked-for restraint.

If born or introduced into captivity at an early age, wild animals can be habituated to captivity in different degrees, but sooner or later some irritating incident arises, which in freedom would be passed over with scant notice, and tragic consequences result.

The dog, by reason of the position man occupies in his canine mind as representing the pack, will support moderate restraint for short intervals, but the cat, which only associates with man as the jackal does with the tiger, will not suffer restraint of any kind. If tied up, the cat fights to escape, and generally, in its violent struggles for freedom, succeeds in hanging itself.

Who, when at a menagerie, can have failed to be struck with the never-ceasing movement up and down the cage, the miserable captives perpetually trying to find a way out ? In nature there is ordinarily a way of escape from any position in which a free denizen of the jungle finds itself.

They vainly but instinctively feel there is a way out, if only it can be found, and are quite unable to regard inanimate chains, bars and walls as real, absolute barriers. Their constantly deferred hope causes deep depression and resentment, and they hate and suspect everything endowed with life as their enemy. A comparatively slight annoyance in these circumstances is sufficient to rouse them to panicky action, to their own disadvantage.

\section{In Confinement all Natural Habits are perverted.}

When animals are confined in narrow enclosures, all their natural habits are perverted. Observation of the ways of either herbivorous or carnivorous captive animals would entirely mislead the student of natural history if he assumed they would so act in freedom. Such a student would fall into similar errors as those in which the " aristocracy of intellect," the neo-Malthusian and other superficial philosophers wallow with regard to their fellows who are also confined within narrow enclosures. 
Even the domestic cow or mare, kept in an enclosed space, has been known to attack its newly born offspring when irritated by the well-intentioned interference of outsiders. At the Zoo, captive wild animals quite commonly attack and devour their young, even though the parent be well fed and cared for by the skilled keeper. The white bear Barbara is a notorious offender in this respect.

Darwin has some interesting observations to make upon the influence of captivity on fecundity in animals, including man. He teaches that even slight changes in environment by unnatural restraint unbalance the rate of reproduction. In some species, notably domesticated cattle, dogs, cats and rabbits, they become more fertile than they were in a free state, whilst in others there may be sterility or lessened fertility. He remarks: "And as bearing on the above cases of man, it is important to remark that the young are apt to be weak and sickly or malformed, and to perish at an early age."

\section{The Hostile Environment of Captivity.}

We are now in a position to understand why animals in the abnormal condition of captivity act in direct contradiction to the whole tenor of their lives. In a narrow enclosure, the captives may be regarded as individually chained up close together. They are living in a hostile environment.

In the overcrowded corral, cattle have been known to turn upon each other in their frenzy, irrespective of age or sex. An infectious emotion like that of fear communicates itself from one to the other until all are in a panic, and nothing, save freedom, can restrain the temporary insanity induced. The excitement only ends in death or exhaustion, the miserable survivors presenting an unhappy scene of apathy.

At rare intervals abnormal natural conditions have been known to produce such an aberration of the social instinct among quadrupeds as those frequently occasioned in the artificial corral. The rivers in the Pampas in an extraordinarily dry summer have, by a combination of drought and salinity, been made undrinkable in certain districts.

Azara in his Travels describes, as the result of such a calamity, the fury of the wild horses, mad with thirst, as they rushed into the marshes, those which arrived first being overwhelmed and crushed by those which followed. He 
states that more than once he has seen the carcasses of upwards of a thousand wild horses, thus destroyed.

\section{The Key to the Problem of the Origin of War.}

It is manifest that we are in possession of the key to the whole problem of the origin of war. War is a biological blunder perpetrated as the result of a derangement of instinct or intelligence.

In turning against a distressed comrade, the herd of cattle oppose themselves to the law of their being, to the whole system of instincts and habits which have made it possible for them to live together in communities, or even to exist at all. They commit an atrocity in the delusion that they are rescuing their distressed fellow. Instead of preserving the species, the animals are perpetrating a "noble and glorious" mistake unknowingly.

Within the hostile environment of the " overpopulated" corral, the cattle are "living dangerously." They seek to preserve themselves by destroying each other, motived by the aberration of the instinct of self-preservation.

\section{The Factors composing the Equation "War."}

Rudimentary war, the violent attack of animals upon a member or members of the same species or family, which occurs indiscriminately as regards sex, age or condition, is an error into which animals fall, actuated by false stimuli.

The conditions favourable for an outbreak of violence are captivity or enclosure caused by an unusual or sudden change of environment for which the animals are not, or have not become, adapted, sudden illness, or injury from not easily ascertainable cause, not frequently met with in the ordinary effort for existence.

In such cases the hereditary or acquired instincts do not extend, and cannot provide for the abnormal conditions, and an aberration of the social instinct takes place.

To initiate the violence, an exciting incident, such as a struggle or cry for help, may be necessary, much as a spark sets into blaze a collection of combustible material.

The factor of captivity is supremely important in the psychology of that temporary insanity we call war. The irritating incident is of lesser importance. 


\section{RUDIMENTARY HUMAN WAR}

\section{READER'S GUIDE}

IN Chapter VI rudimentary human war is shown to be caused by superstition.

\section{The Headings are:}

Man's Relation to the Lower Animals-The Survival of the Atrocity-Hatred is due to the Perversion of the Intelligence-Good-nature, Goodwill and Ill-will-The Deterioration of Family Life within the enveloping Hostile Environment of Social Injustice-The Effect of Imprisonment on Human Beings-The Pursuit of Happiness and the Struggle for Existence-Some Fxamples of Adventitious Enclosure-Wars and Civil Commotions are not " caused " by Frivolous Incidents-The Hope that War may end War-The Inconclusiveness of War-Human Nature vindicated-What we have to discover. 
I made him Just and Right, Sufficient to have stood, though Free to Fall. Milton. 


\section{RUDIMENTARY HUMAN WAR}

\section{Man's Relation to the Lower Animals.}

Man, lord of the primates, differs transcendentally from the lower animals, more especially in the range and capacity of his mental nature. Physically a weak animal, his great superiority lies in intelligent power to modify his immediate environment, and the experience gained in exercising this power reacts in the development of his moral or spiritual nature.

Possessing freedom of choice in a greater degree, his power therefore carries greater capacity for disaster, when error overtakes him, than in the case of the "beasts that perish."

Although intelligence has evolved and diversified upon instinct until the latter has almost become submerged, man is by no means infallible, and intelligence, like instinct, can blunder. Religion can decompose into superstition.

We know that man's intellectual attributes do bear some relation to the instincts of the lower creation, and that these attributes must also exist in conformity with, and be governed by, the same laws of Nature.

We know that in common with the lower animals, which blunder by the aberration of instinct, man can also fall intelligently in similar ways, in similar circumstances.

\section{The Survival of the Atrocity.}

Those of us who have seen a fellow-creature affected by a sudden seizure accompanied by a struggle, or caught in a natural trap such as a fall of rock, and heard the shriek for help, will have vivid recollections of the sensations occasioned.

There is undoubtedly a violent impulse to attack something endowed with life and motion like ourselves, and this instinctive emotion, especially in youth, is quite difficult to 
control. Upon reflection, we have been surprised at the actions of ourselves and others at such times, and wondered why we were so rough in our first aid to the victim.

The emotion is of momentary duration, because our reason corrects it, and we soon proceed, after some experience, to render useful aid immediately.

Although intelligence has corrected involuntary error in such cases, there is yet a survival clinging to the skirts of inexperience. We see the evidence of this survival in the unreasonable behaviour of people in street accidents, when an injured person is not infrequently hustled in a goodintentioned desire to rescue on the part of the crowd.

In moral crises it is, however, more than a survival.

For example, when, owing to not easily ascertainable causes, a father or a son has been suddenly overwhelmed by financial disaster, or a daughter has committed a social indiscretion, although the more intelligent, but not necessarily more tender-hearted, members of the family will almost immediately give substantial evidence of goodwill, others, normally good-natured, will attack the victim with very considerable ill-will, to the great astonishment of disinterested spectators.

\section{Hatred is due to the Perversion of the Intelligence.}

" Hatred," says George Eliot, " is like fire-it makes even light rubbish deadly." Hatred, we know too well, will steel the mind of the irresolute and indolent and cause them to act atrociously.

Those who hate are mentally deranged, and are unconscious of the injury they do themselves, so long as they believe they harm the object of their hatred. The hater mistakes the feeling of revengeful lust for one of the highest purpose, subordinate to any material gain; yet this deluded visionary especially resents the goodwill of others as "idealistic nonsense," or as a pitiful exhibition of what he believes to be deplorable weakness.

That hatred proceeds from ignorance, or lack of creditable knowledge, cannot be doubted by anyone who has seen the depravity which hates in the proportion of benefits received, or hates because it is enraged by high example. There are natures which have become so unhappy as to 
know no enjoyment so keen as the satisfaction of a longcherished grudge. Superstition battens upon malattributed or imaginary grievances.

Under the influence of this mind-imprisonment, haters see enemies everywhere, and frequently in vivid expectation they attack friends in false-seeing anger. "One of the biggest dangers we have got to face," said a Christian gentleman, after the fall of Power and Might in Germany, "is the extraordinary friendliness of the German people."

The prisoners of hate are in a prison of which they alone possess the key, because no one can convince another of error. Conviction comes from within, not from without, and this after a critical examination of facts, assimilating the true and rejecting the false. Persuasion can only induce the mind to open-can only promote good-nature.

It is well to have a rough-and-ready perception of moral values.

\section{Good-nature, Goodwill and Ill-will.}

Good-nature is the normal animal attribute of the open mind, possessed more especially by unspoilt children and other noble barbarians. No one, however, is entirely without it, for it is the manifestation of the social instinct, or the love and sympathy everyone feels for oneself and one's fellows.

Goodwill is good-nature enlightened and therefore elevated by creditable knowledge, which is religion. Ill-will, or hatred, is the decomposition of good-nature, and is a reaction produced by defective credence, which is superstition.

Goodwill discriminates between the act which results in evil consequences and the mistaken doer of the act, while ill-will is directed more particularly against the sufferer.

Ill-will is frequently induced by the past harsh domination imposed by others. It is a familiar fact that oppressed persons wish in turn to dominate their fellows. They attempt to enslave and distort the minds, therefore, of innocent children by unfair presentation of facts.

In obstinate mood they invariably suffer reprisals, and they rely upon the ready sympathy of good-nature for cruel wrongs they have suffered, or believe themselves to have 
suffered. Reprisal may be followed by counter-reprisal in small and, to the spectator, almost unnoticeable deeds of unkindness. The effect is cumulative, the whole moral atmosphere surrounding them becoming charged with hate.

This is why, in a family, an insignificant exciting irritation will start off a perfectly alarming state of affairs, so perplexing to the outsider.

\section{The Deterioration of Family Life within the enveloping Hostile Environment of Social Injustice.}

Many unpleasant phenomena of ill-will, thought to be due to inherent faults of character in members of associations like families, are in reality collateral or symptomatic, and caused by enveloping harmful environment, the consequence of decaying and obsolete social institutions.

For instance, it is apparently Nature's intention that the family shall break up to form nuclei of new families, just as the seed-pod upon the plant, as it ripens and dries, is stressed until it bursts suddenly and the seeds are scattered in all directions. Anything, therefore, which acts so as to constrain this natural tendency creates a feeling of hostility. This is discharged in ill-humour, which would never take place were the members of the family free to carry out their destiny.

\section{The Effect of Imprisonment upon Human Beings.}

The effect upon, and the behaviour of, human beings in captivity resembles that of the humbler species of animals. They lose their health and fall victims to disease. They become alternately delirious and listless, possessed of highly coloured hallucinations on the one hand and the grisly phantoms of neurosis on the other. Finally reason forsakes and merciful death releases the prisoners.

While the moral sense of captives tends to become blunted, so that prisoners of hitherto irreproachable character tend to become debased, it is noteworthy that those of religious convictions are the last to succumb, and up to a point may be refined by their incarceration.

It is important to distinguish between culture, which means the possession of superficial physical and mental 
accomplishments, obtained by imitation and persuasion, and religion, which, on the other hand, appertains to man's moral and spiritual nature by conviction.

Erudition may assist in the building of a perfect character, but it can also be turned into an instrument for its debasement, and towards the establishment of a platform of thought and custom in which tyranny and hatred flourish. A knowledge of reading, writing or music may assist expression, but it does not necessarily cause a man to behave creditably towards his fellows.

It is also important to correct the common error that the motive of self-interest is immoral and should be repressed. Those who seek to "better" themselves also tend to raise their neighbours through natural emulation. Persons obsessed with the desire to self-sacrifice in season and out of season are, in common with those inspired with the desire to dominate their fellows, the victims of superstition.

There is a selflessness or apathy which is not less abnormal than the exaggeration of ego we call selfishness. The former is accompanied by the constraint exercised by the latter, and each immoral extreme can be exemplified in one and the same individual.

Goodwill is promoted when self-interest is given the fullest freedom compatible with the like freedom of others. Self-interest so contained is the truest unselfishness, and in effect neither selfish nor selfless. Any interference with this legitimate self-interest produces moral enclosure. It is in both extremes of unreason that hatred finds a source: in selfishness on the one hand, and in neglect of self on the other.

\section{The Pursuit of Happiness and the Struggle for Exist- ence.}

In the freedom of the open air, a race or other competition is enjoyable and health-giving to all taking part. Selfinterest is directed into the pursuit of happiness for each and every competitor, as all revel in the superabundance of fresh air.

But is this any longer true when the competition takes place in restricted enclosures?

Before the hundred and forty-six persons were imprisoned in the Black Hole of Calcutta, they had been 
kind and gentle towards each other, and knew what happiness meant; but in the terrible dungeon they entered into competition for the artificially restricted fresh air, which came from one small opening.

Self-interest was not directed into the pursuit of happiness by any of the captives who in this terrible environment struggled murderously for existence, as they selfishly disregarded each other's interests.

In any prison, whether moral or physical, self-interest is inflated into egoism or depressed into apathy. All are subject to derangement of intellect, and it is in this environment that men are degraded into savage brutes or sink into despair, while women are filled with hatred, willing to descend to any profligacy for self-preservation. All are compelled to enter into cut-throat competition to the death for life alone, and the consequences are harmful for all, including the survivors continuing to prey upon each other. It is WAR.

\section{Some Examples of Adventitious Enclosure.}

Azara's story of the wild horses on the Pampas is paralleled by what took place at the coronation of Nicholas II at Moscow in I894.

The people were offered a free feast of beer, brandy and buns, and when the hungry crowd proceeded to the place where these things were being distributed, a crush ensued. Those in front were knocked off their feet by those behind, and in turn these were crushed by people yet further back. No one seeing what was happening in front, they all kept pushing and pressing each other on.

The weak were overthrown by the strong, and then the strong ones themselves, suffocated by the crush and want of air, also fell to the ground, and were trampled by those who were pushed from behind and could not halt. Several thousand persons, old and young, male and female, in this way met their deaths or were injured.

After the tragedy, people began to argue as to where the blame should be laid. Some said it was the police, others the organisers, while many blamed the Czar for initiating so silly a device for entertainment. They thus accused everyone but themselves, and yet it is clear that, in order to obtain 
a handful of cake and a pot of beer before their neighbours, the tragedy was due to those who rushed selfishly forward hustling and trampling their fellows.

The panic which took place in a picture palace at Deptford on April 26, I9I7, is a good example of rudimentary war produced in a confined enclosure.

Upon this occasion, while the pictures were being shown to the sightseers, mainly composed of children, an alarming noise was made, caused by a stone having been thrown from outside into the fan of the ventilator.

The panic-stricken children made a rush for the exits, and passers-by, infected by the panic, raised the cry of "Fire!" The attendants did all they could to calm them, but amid their screams, and the shouts of the people from the street, many of them parents trying to force their way to the rescue, little could be accomplished. In the wild struggle for the exits, blocked by the rescuers, four children were crushed to death and ten others were seriously injured.

At the inquest, one of the fire-brigade officials said he thought the deaths of the children were owing, in a great measure, to the ungovernable way in which those people behaved who were trying to effect a rescue.

These typical examples, which might be multiplied indefinitely, serve as illustrations to show that like causes produce like effects among mankind as among the lower animals, "which have not understanding."

\section{Wars and Givil Commotions are not "caused" by Frivolous Incidents.}

It has frequently been alleged that in times of popular excitement the discontented mob has been provoked to violence by some irritating action, such as the missile thrown into the midst of the crowd by an agent provocateur, arranged at a time to suit the convenience of the police and military forces, who are popularly believed to keep law and order. The latter are then presumed to be justified in the use of weapons to scatter the enraged people, who menace the public peace, or at any rate spoil the " repose" of authority.

It would be a narrow view to take, that the thrown missile was the cause of such a tragedy as civil rioting. The true cause lies deeper in the retention of archaic institu- 
tions which generate the discontent. For this the mob, owing to their mental blindness, are as much to blame as anyone.

In similar manner, by means of some pretext diplomatically arranged, it is alleged that governments, supposed to control the destinies of civilised countries, have upon occasion started violent action between the armed forces which are believed to preserve the freedom of the seas and the dry land. The use of terrible engines of war is then presumed to be justified in the manifestation of temporary insanity which subsequently takes place.

But it would be absurd to see in these frivolous episodes the fundamental cause of war, which must be referred back to some cherished superstition of which the nations are for the moment insensible. Defective credence is what enslaves nations as well as individuals.

\section{The Hope that War may end War.}

It has been somewhat thoughtlessly said that "War is a relic of barbarism." Far, however, from being a " relic," war becomes increasingly more frightful and extensive. Nevertheless, it would be equally erroneous to ascribe war to its being a concomitant of civilised progress and to say that it is a product of culture.

Wars in the early stages of what we have hitherto known as civilisations are more frequent and smaller, but they tend, as these cultures develop, to become bigger and more destructive. This is of course owing to the fact that increasing knowledge in chemistry, physics and other branches of science is at the service of those who hate each other. Emulation is directed towards developing means of killing into more effective shapes.

In proportion as wars become increasingly insensate and gruesome, it is not surprising from our new point of view that "glory and honour" in them increase, having regard to the highly deranged reason or intelligence which motives them. Those taking part believe they are fighting for, or to preserve, their freedom, let disillusionment afterwards be what it may.

That war may be rendered so deadly that men will refuse to fight is in the nature of things improbable, to say 
the least. All experience goes to show that such a hope is doomed to disappointment, and it is well, from the right point of view, that it should be so. We shall learn; it is unthinkable that the human race is to perish in a cul-desac, and equally incredible that humanity is to remain an irredeemable slave within the flimsy barriers of superstition.

\section{The Inconclusiveness of War.}

Speaking in the British House of Commons upon the I9I9-20 Estimates, General Seely, referring to the first air fight which he had witnessed, said: "I remember Sir David Henderson saying to me the same day, 'This is the beginning of a fight which will end in great battles in the air, and in which hundreds of thousands of airmen will be engaged '; and I said to him, 'Is it possible that human endurance and human courage will be equal to that stupendous task ?' He thought so, and he was right. . . .

"Since that one air combat which I witnessed in September I9I4, we have this astonishing fact, that during the war just under 8,000 enemy machines were shot down by our pilots in all theatres of war; 2,000 of our machines were missing, and most of them were similarly shot down. When one comes to think of what these figures mean-probably 40,000 or 50,000 desperate battles in the air, sometimes far away in the enemy territory, and occasionally right away over wide stretches of sea, where the failure of an engine at any moment would have meant certain deathI think we can only bow our heads in respectful admiration to incomparable valour."

\section{Human Nature vindicated.}

Futility and senselessness could not be more highly idealised, but it is consoling to reflect that the sane patriotism and devotion inherent in humankind are not less splendid. The belief that war was ineradicable from human nature has been a cause of sorrow for those who looked beyond the glittering Pomp and Circumstance which masks the squalid reality of the intoxication of Patriodium.

It may be humiliating to conclude that war is due to an aberration of intelligence caused by superstitious enclosure 
but there is hope on the horizon from our point of view, which is better than fatalism. The stigma upon human nature has vanished.

\section{What we have to discover.}

Our field of investigation has been narrowed down considerably. We have to discover the nature of the now invisible restraints in society which produce the frequently recurring inflammations and eruptions.

These slaveries may be many and various, but we do know that they can be considered under two heads, e.g. personal, or direct, and impersonal, achieved indirectly by the restriction artificially of our immediate environment.

Having ascertained how mankind can enslave themselves, the remedy should not be far to seek. Obviously freedom is the cure for captivity. 


\section{EQUALITY OF OPPORTUNITY}

\section{READER'S GUIDE}

IN Chapter VII the superstition that the earth itself can be the subject of private or public ownership, in the way that things are, is revealed as the fundamental cause of the stresses and strains in human relationships that produce war. The remedy is to restore equality of opportunity by collecting rent where it appears, and making return of it to the people in equal services, and at the same time abolishing tribute upon the activities of the people.

\section{THE HEADINGS ARE :}

The Importance of the Correct Point of View-All Men and Women conscientiously object to War-The Survival of the Fittest in Ideals-Alternations in Human Credence-The Strong Men of History-The Principle of Equity-The Spencerian Limit-The Law of RentPublic Services of Monopolistic Nature should belong to the Public-The Distinction between Wealth and the Source of Wealth-The Effacement of Old MeaningsThe Law of the Land-Land, the Source of Wealth, is, and always has been, a National Possession-What is Slavery ?-Slavery is the Cause of "Overgrown Populations"-False Prophets and Devil Worship-Slavery is Man's Original Sin-Justice is the Basis of Peace and Reconstruction. 
If you take a sword an' draw it, An' you stick a feller through,

Government ain't to answer for it :

God'll send the bill to you!

LOWELL.

There is only one cure for the evils which newly acquired freedom produces; and that cure is freedom. When a prisoner first leaves his cell he cannot bear the light of day; he is unable to discriminate colours or recognise faces. But the remedy is not to remand him into his dungeon, but to accustom him to the rays of the sun. The blaze of truth and liberty may at first dazzle and bewilder the nations which have become half blind in the house of bondage. But let them gaze on, and they will soon be able to bear it. In a few years men learn reason. The extreme violence of opinions subsides. Hostile theories correct each other. The scattered elements of truth cease to contend, and begin to coalesce. And at length a system of justice and order is educed out of the chaos.-Macaulay. 


\section{EQUALITY OF OPPORTUNITY}

\section{The Importance of the Correct Point of View.}

It has long been the boast of scientific students that the earnest worker will publish what he is satisfied is a right conclusion, based upon the evidence of carefully observed results obtained by experiment and calculation. He is not indifferent to the fact that the verdict may render obsolete pet theories and apparently thrust aside as useless the toil of years in former researches; but he is impelled, even at the risk of temporary estrangement from interested colleagues, to make known the truth.

Patient adherence to a revealed principle invariably opens up wider fields of opportunity for happiness and further progress. One-time unsolved problems solve themselves, and a new world may be discovered by looking for it from the right point of view, undeterred by vested ignorance.

So long as astronomers took the earth literally as their point of view they were confirmed in the delusion that it was flat, stationary and the centre of the universe. Copernicus, by means of careful observations and calculations, and by viewing the system from the outside, discovered discordance in the then current theory; but he only published towards the end of his life the conclusions which were to incur such hostility before general acceptance.

The complicated Ptolemaic system of astronomy was at that time generally unquestioned, and the new, simpler conception came to disturb the repose of professors who had devoted their lives to the understanding and elaboration of its intricacies. New ideas were not welcomed by organised so-called religionists, who were resentful of anything that might threaten the foundation of error sustaining their caricature of religion. Copernicus diplomatically dedicated his book to Pope Pius, who did not. appreciate the 
great honour, and the author unfortunately incurred thereby the hostility of the Protestant pope Luther, who said the new doctrine was impious, contrary to scriptural revelation.

Truth always finds friends. Hundreds of miles away, after some years, Galileo subscribed to the Copernican hypothesis that the sun, and not the earth, was the centre of the planetary system. For this and similar heresies he was brought before the bar of the Inquisition, and by threats was induced to recant and forced to declare that the earth was as flat as a pancake. "Yet it moves," said our hardy conscientious objector.

So also moves the tide of credence, which cannot be stemmed by papal bulls and other supposed infallible authority. Tycho Brahé, Kepler and Newton made discoveries in the laws of Nature which revolutionised the sciences. Columbus discovered the New World of America.

The works of Galileo and Copernicus were forbidden to all good Catholics, and were upon the Index for over two hundred and fifty years, or until the year I836. For teaching the truths of natural science Bruno was burned alive and his ashes scattered to the four winds.

Said Archbishop Ireland: "The enemies of the Church have been inside the Church, not outside of it. The supreme blunders of churchmen have been in suppressing strong men-in thwarting individuality. All the good law and all the good orde1 which the State or Church enjoys to-day may be traced back over some route to the words and deeds of men who rebelled against the kind of law and the kind of order which they found administered by its 'constituted guardians ' ; by men who dared to appeal from the 'keepers of divine truth' to divine truth itself-from the 'trustees of God' to God Himself."

So important is correct point of view.

\section{All Men and Women conscientiously object to War.}

It is possible to sympathise with an English bishop who said that the conscientious objectors to the taking of human life were wrong. He based his belief on the operation of the laws of Nature, for, said he : "Did we not live on a planet which rushed through space at ten miles a second, and yet we were retained upon its surface by the downward 
pressure of 70 miles of atmosphere." Was it extraordinary that a vigorous recruiter of volunteers, disconcerted possibly that he lived upon such a planet as that, should plead, when conscripted at a later date, that he was now a conscientious objector?

The danger of the little knowledge is always made apparent in the divorce of reason and instinct. The modern Sadducees hold that in view of the fact that more people are obviously in the world than are wanted, and "human nature being what it is," the sexual atrocity which in many civilised countries is licensed and organised by the State should te tolerated.

The young man, introduced to the social aberrations of the West End, may conscientiously object to partake in the vile orgies attending the White Slave Traffic, and be subjected to a latitudinarian discourse upon the purifying effects of vice and the ennobling duty of sowing wild oats. Reasoning from a narrow point of view, even a Presbyterian Cabinet Minister may point out to the young man that his instinctive repugnance, if it became more generally obeyed, might lead to more serious consequences for society, which the organised perversion was designed to preserve.

Just as all men and women are conscientious objectors to prostitution, so they are to war; not less the courageous hundreds of thousands who voluntarily rushed, as they thought, to preserve the community in the Great War than the brave minority of ridiculed and wronged conscientious objectors whose instinct and reason combined in rebellion against the participation in physical and moral violence.

Men love to face ordinary dangers in work and play, but it is only when under the influence of temporary madness due to seeing things falsely that they appear to love war. Soldiers who have seen active service have none of the mean enmity exhibited by those whose "patriotism," Dr. Johnson said, was " the last refuge of the scoundrel."

The warriors of the Iliad, the Maccabees, the Covenanters and the contending armies of the American Civil War all desired peace and hated war as intensely as the Society of Friends. They were all pacifists fighting for a just peace.

Viewed narrowly, it may appear that War is a Biological Necessity; but from the broader point of view it is plainly 
seen that men only resort to war, which they hate, because by doing so they imagine they will obtain something which they really desire, or avoid something which they fear worse than death. It is Freedom which is a Biological Necessity.

\section{The Survival of the Fittest in Ideals.}

There is a survival of the fittest in ideals as in species. The more truthful expression will survive, even though opposed by a world-wide organised superstition-even though a new civilisation require to be born from the ruins of an effete culture.

Pioneers need not be alarmed if they find themselves alone or in the great minority. The victory of the Truth is not determined either by the sword or the ballot-box, and we should not stand appalled if we hear it said : "Yes, I agree, but then everyone may not see from this point of view." God and one form a majority!

It is not meet that the truth should be proclaimed at unseasonable times: "pressing" only delays acceptance ; but that is not to say that the correct point of view should be hidden-that our light should be put under a bushel. "Let no man think he is without influence."

\section{Alternations in Human Credence.}

The advancement of religion or creditable knowledge has not followed a smooth upward tendency during the historical period. Approximately just ideals have crumbled, to be replaced, as they have collapsed from time to time, by better approximations, which in turn have given place to others. The just ideal will be disclosed when the correct point of view is universally accepted, and it will fitly survive.

As regards the alternations in human progress of thought, it is interesting to note that while each peak in the curve of achievement shows superiority in certain branches of skill and knowledge characteristic of the period, and while in some respects the older civilisations have not as yet been surpassed, a general advance may be said to have taken place in the tide of human credence.

During the current epoch civilisation has been distinguished by the great advances made in the mathematical sciences, firstly in astronomy, which led to discoveries in 
mechanics and chemistry. Advancement in one branch of knowledge makes possible progress in others. In biology the static tangle of theories of special creation has given place to a simplified system founded upon progression by evolution from lower forms of life. The dynamic mode of thought, exercised in biological speculations from the new point of view, has made return in astronomy and physical sciences generally and rescued them from formalism.

Now the close fellowship of the sciences is being further exemplified by the assistance which the apparently remote science of sociology is deriving from the advancement made in biology. The assistance is timely, for sociology and its handmaid, political economy, are only now emerging from the dark ages of superstition. It is not yet sufficiently recognised that society grows like a plant, and becomes blighted when freedom is denied the individuals composing it.

\section{The Strong Men of History.}

Copernicus, Newton and Darwin are as much the liberators of mankind as Moses and Lycurgus. The truly great men of history have not been the Herods, Alexanders and Napoleons, who led the way into greater darkness, but the conscientious objectors to slavish error, who formed a nucleus for the assimilation of enlightenment pointing the road to freedom.

The modern prophets, Hegel, Carlyle, Emerson, Ruskin, George, Tolstoy and a cloud of other witnesses, are only more definite than Isaiah, Micah, Confucius and other ancient teachers who lived upon an earlier platform of knowledge. The saying of the Psalmist, "The meek (e.g. the goodwilled) shall inherit the earth," $x$ is not less a biological truth because it was a conclusion based apparently upon insufficient knowledge of the survival of the fittest.

The sound and fury of the militant evolutionists signify nothing. Their pretentious supermen and warlords in shining armour have shown themselves to be mere human scarecrows bursting with puffed ego. In incoherent autobiographies they crave for the sympathies of their fellows and a balm for wounded pride-objects for pity where they do not inspire disgust.

I. Psalm xxxvii. II. 
They have shown, however, how minds preoccupied with the mirage of imperialism fail to unlearn the superstition that Might is Right. Blind themselves, they either deny the existence of Justice or conjure a blindfolded personification armed with a Sword, whose real name is Might without Mercy.

Either Justice is Right or Might is Right. If the latter, there can be no peace, only Silence and Desolation. The basis of Peace and Survival is Justice, therefore Justice is Right.

\section{The Principle of Equity.}

It has been contended by some legal and scientific authorities, with much show of reason, that natural rights do not exist. Such a contention is not in accordance with the fact that we exist because natural rights exist. They are, in fact, as real as instinct or intelligence, and mere verbiage cannot argue them away.

There are two alternatives, as we have seen-either might is right, in which case we may only fight and devour each other to extinction, or else justice is right and human existence is possible by agreement to live peaceably together on equal terms. It is from this fact of existence that we derive our principle of equalness, or "Equity." Equality of opportunity to life, liberty and the pursuit of happiness is our inalienable right, and any infringement of the law of freedom interferes with the survival of the fittest-tyrants live as dangerously as their victims.

Herbert Spencer (before he fell a sacrifice to mind polarisation) demonstrated that natural rights included a frank recognition that every man or woman is the one true owner of his or her own body and mind; that each person must be free to employ his faculties, or the product or gain of his faculties, according to his own choice and to the best advantage for himself. He considered that this freedom was limited only by ihe like freedom of others.

"If the assumption that land can be held as property. involves that the whole globe may become the private domain of a part of its inhabitants, and if, by consequence, the rest of its inhabitants can then exercise their faculties -can then exist even-only by consent of the landowners, 
it is manifest that an exclusive possession of the soil necessitates an infringement of the law of freedom. For men who cannot live and move and have their being without the leave of others cannot be equally free with those others." (Herbert Spencer.)

Equity, therefore, does not permit private property in land, and this contention has never been, and can never be disproved.

"Every generation of men has the same free right to make its own arrangements, and to carry into effect the principles it knows or believes to be true, quite independently of the arrangements that have been made by anterior generations. The earth and all it contains belongs, for the time being, to every existing generation. The disposition of the earth, as the great storehouse from which man must derive his sustenance and support, is not to be determined by the laws, customs, arrangements, kings' gifts, or prescriptive rights of any past generation of men, but by the judgment and reason of the existing generation, ordering all arrangements according to the rules of equity, which are always valid and always binding." (Patrick Edward Dove.)

Time, which may be a great legaliser, cannot convert a wrong into a right. Time has only intensified the continuing wrong of private property in land; and it is worthy of remark that while the enactments with reference to crimes against the person have always been considered alterable, those with reference to property have continued, making reasonable actions legal crimes.

Those profiting in injustice, who place Property before Humanity, and the lawyers, who venerate the law and care nothing for Equity, know they stand upon dangerous ground. Said an honest lawyer : "It is well if the mass of mankind will obey the laws when made without scrutinising too nicely into the reasons for making them." (Blackstone.)

\section{The Spencerian Limit.}

As a corollary to his demonstration of natural rights, Mr. Spencer held that some restraint might be necessary for those cases "where persons employ their faculties to interfere by force or fraud with others in equal use of their faculties." 


\section{The Law of Rent.}

Belief in the private ownership of land is a comparatively modern form of error. To the nomadic mind, no matter how degenerate in credulously imagining that man may own his fellows as he may sheep, land was never regarded as the subject of more than temporary possession, as pasture for flocks and herds.

When the patriarchal slave-owner proceeded on slaveraids, his ambition did not at first extend to the ownership of land, although he quickly discovered that the most effective way to obtain slaves was to assume ownership of it where and when land had become the subject of ownership in the philosophy of those living upon it. The mere claim to land-ownership is of no value, unless others desire access to it and are willing to accept the terms of the so-called owner.

Security of tenure is necessary for the purposes of agriculture, and the claim of the first comer to possession without dues or compensation is universally conceded, so long as other land as good is available. It is no offence to occupy a vacated site and refuse to restore it upon the return of the former occupant if some considerable time has elapsed.

Some land is more desirable than other land, it may be because of its advantageous position or because of its greater fertility. Upon this superior land the application of human labour gives a better return than an equal amount of labour applied to inferior land of the same area.

When all the desirable sites have been occupied, it is plain that those cultivating the less desirable are at a disadvantage as compared with those in possession of the better land. The same considerations apply when the land is used for other purposes than agriculture, as, for example, building, quarrying, mining and manufacturing. Since all have equal rights to possession of the earth, before the occupants of the more desirable sites can consider their tenure secure against all others they must devise some means of equalising opportunity in their neighbourhood.

The difference between the returns for equal amounts of labour upon the respective sites, area for area, provides a measure for creating an equalising fund. This equalising 
fund becomes apparent in the free competition for sites as population makes its appearance and increases as population increases. It is manifest in the form of land-value rent, land beyond the margin of cultivation paying no rent, because there is no competition for it.

To afford everyone equal opportunity to the land for use it is only necessary to collect the fund of economic rent and return it in equal portions to every member of the community.

\section{Public Services of Monopolistic Nature should belong to the Public.}

The ownership of public monopolies, in the hands of one or of an exclusive set of persons, carries with it the power to tax, exploit or otherwise to oppress others. Experience shows that in the long run such power is invariably put to a wrong use, the beneficial regulation of natural competition being destroyed by legislative concession, which cannot be equitably adjusted by Governmental control.

In land-value rent, which of right belongs to the whole community, no one individual having a greater title to it than another, we have, as the result of the operation of the law of equity, a fund ready at hand for the provision of social necessities of a monopolistic nature.

Such social necessities are the common roads, irrigation systems, water supplies and other circulatory services, which, decided by general unanimity, it is desirable that the whole community should be the owners and free users. In highly civilised communities the circulatory services may include postal facilities, telegraphs and telephones, railways and transport in shipping; but, notwithstanding the desirability of communal ownership in such cases, it would be an infringement of the law of freedom if any individual or group of individuals were debarred from possessing their own private roads, message-carrying arrangements, railways and docks, so long as they paid over to the public the full economic rent for the land they occupied and did not interfere in any way with the equal opportunity of their fellows.

To be in accord with the law of equity, each individual of the community should have not only equal opportunity with every other individual or group of individuals, but 
even with the community itself. This proviso is necessary not only for the satisfaction of justice, but also to ensure that improvements, which are invariably made by strong individuals, should not be rendered still-born. Community undertakings benefit by emulation just as smaller undertakings do, nor should they be allowed to grow into State monopolies, which impose indirect taxation upon the community.

\section{The Distinction between Wealth and the Source of Wealth.}

It is in not clearly distinguishing between wealth, which is the product of labour, and the source from which all wealth is drawn that many earnest thinkers have fallen into confusion. Individuals may exchange with each other and with the community as a whole all forms of wealth, including roads, telegraphs and telephones, and railways; but they may not traffic with the earth itself, the source or " mother solution" of man, from which he crystallises.

Neither individuals nor the State or community can own the earth in the intimate sense that they may own improvements upon its surface or wealth in any form the product of human labour, all of which eventually decomposes back into the source from whence it comes. All that the community is entitled to take at first-hand is land-value rent, where and when it appears, to ensure everyone equal opportunity to the earth for use.

It is possible to live happily without such luxuries as roads, railways and the telephone; but without free access to the land, which in its economic meaning includes all natural resources, such as the air, sea and sunshine, it is impossible to exist as healthy and free creatures. Just as human beings who belong to themselves may not be bought and sold, so may we not buy and sell the earth to which we are all equally entitled. "Men talk of selling land," says Carlyle, " but the notion of selling for certain bits of metal the land of the World-Creator is a ridiculous impossibility! Who can or could sell it to us?"

\section{The Effacement of Old Meanings.}

To have the "freehold " of land in England did not originally, and does not now, mean the absolute ownership 
of land, but its literal meaning, to hold, conditional upon the rendering of military services and/or the payment of dues in money, labour or kind. Freeholders are tenants of the "crown" or community, the king being a trustee merely. "Copyhold" is the base tenancy of a peasant or serf by copy or custom to a lord of the manor or other crown tenant. Contrary to popular belief, serfs were not chattels to be bought and sold, but were attached to the manor, and could not move to another district without the lord's permission.

"Land tenure" meant the tenancy and not the ownership of land, and "rent" was not the property of individuals, as it is now claimed, but the revenue due to the crown, as in fact it is. No crown tenant can give a better title to the land he holds in relinquishing it than that given to him by his predecessor.

Let us open the Books of the Law and examine this title.

\section{The Law of the Land.}

"The first thing the student has to do is to get rid of the idea of absolute ownership. Such an idea is quite unknown in English law. No man in law is absolute owner of his lands. He only owns an estate in them." (Williams, Real Property, I2th ed., p. I7.)

"All lands or tenements in England in the hands of subjects are holden mediately, or immediately, of the king. For in the law of England we have not any subjects' land which is not so holden." (Coke, Institutes, p. 488.)

"It being a received and now undeniable principle in law that all lands in England are holden mediately or immediately of the king." (Blackstone, Commentaries, vol. ii. p. I06.)

But while the principle of equity with regard to land tenure has always existed, the just method of carrying out the principle has never been established, and for the very good reason-it was not known precisely. The nature of rent was not discovered before the time of Adam Smith and Ricardo, who explained from what source it was derived. Ricardo demonstrated that the rent of land is a specific, not an arbitrary quantity, and represents a return to ownership over and above the return which is sufficient to induce use. 
To take, therefore, for public purposes, by way of taxation, a part or the whole of this premium in no way affects the incentive to use of land or diminishes the return to which the user of the land is entitled; in no way diminishes the amount of land there is to use or makes it more difficult to obtain it for use. "A tax on rent falls wholly on the landlord. There are no means by which he can shift the burden upon anyone else. It does not affect the value or price of agricultural produce, for this is determined by the cost of production in the most unfavourable circumstances, and in those circumstances, as we have so often demonstrated, no rent is paid. A tax on rent, therefore, has no effect other than its obvious one. It merely takes so much from the landlord and transfers it to the State." (John Stuart Mill, Principles of Political Economy, Book V, ch. iii., sect. 2.)

The conception of economic rent-that is, rent fixed by free, unrestricted competition for sites among would-be users-is probably not new except in its modern scientific form; but in early practice, the general absence of money as a medium of exchange and as a measure very likely discouraged accurate assessments. Favouritism crept into the feudal system, with its usual disastrous results. Instead of rent or revenue based upon the value of the holding, there was an assessment made arbitrarily, which eventually deteriorated into an assessment according to the indefinite basis of ability to pay.

Jealousy and discontent always attend a system where tenants are not given equal opportunity, and where personal bias in picking and choosing is possible. An income tax necessitates governmental control, and ability to pay in time becomes inability to pay more. Landholders became so saddled with burdens that finally they revolted against their overlord or king. It was the reaction due to this rebellion which favoured the growth of the idea of dominium as opposed to usufruct.

Landholders in time and upon occasion gradually changed the incidence of taxation, and imposed their load of feudal obligations upon the landless toilers by means of a complicated penal system of rates and taxes. It is in this way that we have drifted, landed and landless alike, into our present lamentable condition. 
Land, the Source of Wealth, is, and always has been,

a National Possession.

The king betrayed his trust when he made grants or gifts of lands to favourites, who either paid no rent to the crown or a mere acknowledgment. The rent of land cannot be alienated from the crown, and any short-sighted appeal on the part of holders for " compensation," because an impression has gained ground that they are absolute owners, can be met by the demand of equity that arrears of rent of land held, whether used or unused, shall be paid over to the community by so-called landowners who have been collecting it.

Not only is it morally wrong to propose that those who now suffer because the community has lapsed into superstition should pay "compensation" to the persons profiting by injustice, so converting landlords into bondlords, but land cannot be bought back-cannot be " nationalised " by purchase. The land is, and always has been, a national possession ; therefore it is only necessary to assert the Common Right, and proclaim that upon an Appointed Day the Crown shall collect for the People the Economic Rent, which is the outward and visible measure of its Communal Value.

From that day no man, woman or child shall be landless in the community, because all shall be possessors of the national inheritance. It is contrary to self-interest for anyone to pay rent for land which it is intended shall not be put to its best use. In any case, the full economic rent is all that the community is entitled in justice to demand. It is the basis of a Co-operative Commonwealth, because it gives everyone equal opportunity to the source of wealth.

In subscribing their rent to the Common Fund for the land which they hold, users have access to the earth on equal terms with those who propose to use land on the margin of cultivation-that is, land no one else is in competition for, so paying no rent. Thus the Rule of the Land gives security of tenure and perfect liberty of action to all citizens, and consequently inaugurates the State in which injustice and poverty, hatred and war can diminish, because man will be enabled to redeem himself and stand upright. It is the Road to Freedom. 
"The ultimate purpose of the State is not to rule men, to keep them in fear, to subject them to the will of others, but, on the contrary, to allow each as far as possible to live in security-that is, to preserve for each his natural right to live without harm to himself or to his neighbour. No, I repeat, the object of the State is not to transform reasonable beings into animals or automata ; its object is to enable the citizens to develop in security their bodies and minds, freely to employ their reason. The true end of the State, therefore, is liberty." (Spinoza.)

\section{What is Slavery?}

Slavery is tangential-an indirect consequence of man's intelligence-the result of experimental error committed in a desire to establish a social system which will secure freedom for the community in surroundings which have been rapidly altered during the present biological epoch by man himself, owing to far-reaching advances made in applied knowledge, as, for example, in agriculture. It is not due to the acquirement of inherent parasitism in human nature, but results simply from social drift in a wrong direction, taken in the innocent belief that the direction is a short circuit to a peaceful settlement.

Economic captivity may be of two sorts : equivalent to being tied up, or of being imprisoned in an enclosed space. The former is represented by chattel slavery, while the latter is represented by the barriers of land monopoly. It is a lesson of history, however, that once in an enclosure it is comparatively easy to make one man bond to another or to the State, and herein we find the psychological reason for the reluctance to the abolition of landlordism by those who regard the State as a deity to be worshipped or a devil to be propitiated. Unconsciously, they feel that their little arrangements of dominance over their fellows are in peril when the unreal barrier is threatened.

\section{Slavery is the Cause of "Overgrown Populations."}

It is slavery which is responsible for " overpopulation," caused sometimes intensively by the imperialists in their "forced migrations" of "subject races" into native reservations, and sometimes by the landlords in carrying out 
"land clearances." A little reflection will serve to convince the reader that if all the land of a country were "owned" by one man who exercised his "rights," ten persons would constitute "overpopulation." The landless inhabitants would be compelled to accept a one-sided bargain, and crave for permission to struggle miserably for existence. Herein lies the origin of Niggardly Production.

Actually the great majority of the peoples of the world are landless, and the few persons who claim the earth as theirs are able, by withholding part of it, to bring an elastic, steady pressure to bear upon the remainder. Whether the population is increasing, is stationary or is shrinking, a condition of artificial "overpopulation" is perpetuated, and there is thus rendered available a reservoir of unemployed labourers, whose fierce competition for jobs brings the wages of all who labour down to an iron standard of living. No labourer, whether he is known as a hand or a brain worker, escapes the consequences of this handicap. Idle land means idle men, and the presence of idle men is the basis of wage slavery.

It would be miraculous indeed if there were an adequate supply of the requisites of life in view of the debauching system of landlordism, which depends for its success upon the limitation of such services and commodities

The short supply encourages speculation and profiteering, which results in the creation of usurious capitalists, who lend to the necessitous labourers the proceeds of wage slavery. The competition of the capitalists leads to the growth of combines and trusts, "communities of interest" in privy conspiracy against the public generally.

Super-taxes and excess profits duties, far from remedying the maladjustment of wealth, only intensify it, because, by further shortening the already short supply, the profiteers can pass their taxes and more on to the consumer in higher prices. All consumers are not producers, and the proportion that are have to keep the others and pay their taxes also. The idle-rich loafers, the unemployed poor, those engaged in useless occupations, the swarm of bureaucrats, the army and the navy necessary to prevent a turbulent society from lapsing immediately into indiscriminate anarchy-all are 
supported upon the backs of the wealth producers. All taxes are paid by industry.

Penalising taxation of incomes, houses, machinery and other commodities only makes the increasing number of the poor poorer and the decreasing number of the rich richer. Carried to the extreme, such a policy would eventuate in the abolition of wealth, not the abolition of poverty. The limitation of profits by law is as futile as the limitation of wages or the fixation of rent and prices of articles by governmental control. There should be no excess profits!

What is necessary is the elimination of the loafer by rendering the earth accessible to all upon equal terms. When this is accomplished the labourer will be wealthy, as he was intended by Nature to be. Parasitism will disappear from among men with the emancipation of the labourer, who, free from landlordism, will be independent of the moneylender or so-called capitalist; free co-operation will then replace wage-slavery. This is the true Socialist State in foundation: impulsion, not compulsion.

\section{False Prophets and Devil Worship.}

There is no essential difference between the absolutism of the minority and the tyranny of the majority-the one is as evil as the other. The imperialists, protectionists, State-Socialists and other bureaucrats who would compel the individual, though unwilling, to work or to kill for a Frankenstein monster called the State, are all identical in this, that while they frequently speak and write of freedom and justice, they do not really understand either. Unable to think in the New World while yet living in the Old, they are like the foolish monkey who, thinking himself wiser than his caged brethren, opined that the cage in which they were all imprisoned, and in which they behaved atrociously, was necessary along with the keepers to prevent them all from insurging into barbarism!

All our public misfortunes and the greater part of our private discomforts are attributable to the false Socialism which teaches that the State is entitled to confiscate forcibly human life and the reward of human endeavour. In place of freedom, the priests of Baal believe that a man does not belong to himself-that he has no natural right to keep, 
to give away, or to exchange freely for the labour products and services of others his own services and labour products.

Here is the ideal of vain imagination, the " Aristocracy of Intellect's" State, the antithesis of Spinoza's sane conception :

"The State? What is that? Well! now open your ears, for now I deliver my sentence on the death of peoples.

"The State is called the coldest of all cold monsters. And coldly it lieth; and this lie creepeth out of its mouth : ' $I$, the State, am the people.'

"It is a lie! Creators they were who created the peoples and hung one belief and one love over them; thus they served life.

"Destroyers they are who lay traps for many, calling them the State; they hung a sword and a hundred desires over them.

"Whatever a people is left, it understandeth not the State, but hateth it as the evil eye and a sin against customs and rights.

"This sign I show unto you: every people speaketh its own tongue of good and evil-not understood by its neighbour. Every people hath found out for itself its own language in customs and rights.

"But the State is a liar in all tongues of good or evil ; whatever it saith, it lieth; whatever it hath, it hath stolen.

"False is everything in it; with stolen teeth it biteth, the biting one. False are even its intestines.

"Confusion of languages of good and evil-this sign I show unto you as the sign of the State. Verily, this sign pointeth to the will unto death! Verily, it waveth hands unto the preachers of death!

"Far too many are born: for the superfluous the State was invented.

"Behold, behold, how it allureth them, the much too many! How it devoureth, cheweth and masticateth them!" (Nietzsche.)

So long as the superstition exists that the earth can be the subject of ownership in the same sense that services 
and commodities can be, there is no escape from lying diplomacy, slavery and violence. So long as the prison of superstition remains, "the much too many" will struggle blindly in the dark recesses-ever getting further away from freedom and happiness.

It is for this reason that "nationalising" the land by purchase, or by division among small landlords, as, for example, by way of the Code Napoleon, is foredoomed to disaster. The former policy substitutes the landlord State, which is not the people, in place of several lords, while the latter creates a numerous breed of egotistical proprietors everywhere advocating the limitation of families-" the will unto death." Neither policy abolishes landlordism, which is always attended with the doctrine of Passive Obedience and the Divine Right of the State.

Beware of false prophets, "the preachers of death!"

\section{Slavery is Man's Original Sin.}

Owing to the tendency in individuals to diversify, impelled by the pursuit of happiness in an environment which has a-different phase for every human creature, men and women vary in physical strength, in stature, in mental capacity and quality and in tastes. Even were it advisable, it is impossible for any superman of the "Aristocracy of Intellect" to control, to organise or to coerce for the ultimate good the multifarious activities of a community of which they form part-no matter how important they may think themselves. Their intentions may be benevolent, " the path to hell is paved with good intentions." Political relations are not those of benevolence, but of equity. Justice comes before benevolence.

Benevolence lies beyond politics, and because it can regulate nothing and enforce nothing, inevitably brings about instability and anarchy when it is put in the place of Justice. The reign of Justice must precede the reign of Benevolence, the Golden Rule must be conformed with as regards man and his environment. It is necessary firstly to determine what is due to the individual, and separately to the community, and then the duties and the pleasures of compassion and love will be revealed harmoniously to mankind. 
What ninety-nine persons in a hundred might deem a benefit, the hundredth might account a gratuitous abuse. Charity becomes a monstrosity when those wishing to be free are constrained by it. If the individual has no rights there is no possibility of brotherhood, love or happiness in co-operation in the guild or in the family.

The broken-spirited competitors, knocked out in the race of Restricted Opportunity, eagerly clutch for the doles of prison fare supplied by a stony-hearted State charity organisation. Like the man who, having had his house burnt down, would abolish fire, they catch at the cry, "Competition is the law of death; co-operation is the law of life." Does it not depend upon the kind of competition and the kind of co-operation?

It is natural competition which makes our games so enjoyable, but this happiness is not possible when opportunity is made unequal or men are made "equal" by compulsory communism or wage-slavery.

The competition of three men for two meals or the competition of two men for one job is not beneficial, because it means a life-and-death struggle for them; but the competition of more than one employer for one co-operator " waveth no hands unto the preachers of death." Natural competition is beneficial for the individual and the community, but the unnatural competition in the economic enclosure of land monopoly benefits no one.

Competition and co-operation have each their place in Nature's plan. The world would be a drab and unprogressive abode if either were absent. Happiness attends free competition and the free choice of the individual-the impulsion towards co-operation of free men; but misery is the concomitant of slavery or forced co-operation and necessitous acceptance. Men are not equal, and leadership in co-operative service is essential, but not slave-ownership.

Freedom is the Law of Life; Slavery is the Law of Death.

\section{Justice is the Basis of Peace and Reconstruction.}

The Land was provided by Nature for the Whole People, therefore anyone holding land should pay its Rent to the 
People. In this establishment of the Divine Right of the People do we find the Road to Freedom.

It is in consequence of the failure to observe the logical limitation of what is due justly to the community, and separately to the individual, that, to the intense bewilderment of Power and Might, there is made manifest the "foul buffoonery" of Physical and Moral Violence. 


\section{BOOK II}

\section{THE HISTORICAL ASPECT}

\section{CHAPTER VIII}

\section{THE ORIGIN OF THE PROFITEER}

\section{READER'S GUIDE}

THIs is a short chapter, introducing Book II. In the beginning man was free, like the animals, but as intelligence ripened upon instinct, he experimented, and it frequently came about that he attributed the consequence of errors to the wrong cause.

It was in this way that man drifted into slavery. Owing to the confusion which arose as to the ownership of things produced by individual labour, one capital blunder was to attempt the sharingin-common of wealth by compulsion beyond the limits of the family. Out of the scramble which ensued there originated the profiteer.

\section{The Headings ARe:}

A Period when Man was Free-Primæval Man-How Man drifted into Slavery-Primitive Communes-The Pastoral Patriarchs-The Antagonism of the Shepherd and the Hunter-Polyandry and Polygamy-An Example from the Bible. 
. . as Nature first made man

When wild in woods the noble savage ran.

DRYDEN. 


\section{THE ORIGIN OF THE PROFITEER}

\section{A Period when Man was Free.}

In the preceding chapter it was stated, for analytical reasons, that slavery is a state brought about in the affairs of mankind primarily as the result of experimental error, committed in a desire to establish a social system which will secure freedom for the community of individuals in the presence of a rapidly changing environment caused by the application of man's acquirement of special intelligence.

Referring to the existence of human physical charms, which Darwin contended had been acquired as the result of Sexual Selection-as, for example, great beauty of form, exquisite colouring and musical voice, most noticeable at the present day among well-cared-for children-he remarks : "We may infer that they first acquired musical powers in order to attract the other sex. But, if so, this must have occurred long ago, before our ancestors had become sufficiently human to treat and value their women merely as useful slaves."

Darwin, who included slavery as one of the principal checks to the beneficial operation of Sexual Selection, lived at a time when the woman's economic status compared with that of the man was at a deplorably low ebb. The great biologist was doubtless influenced by the prevailing belief of those who held the then orthodox views of her absolute inferiority, and he may have feared that parasitism in humanity was irremediably established and that civilisation was impossible without it.

From the point of view of the evolutionist, historical records do not go back very far; but even they, when proper perspective is given to the froth and scum of superficialities, show that the volume of slavery rose and fell 
enormously. In the history of every civilisation there are lucid intervals of comparative freedom, and the fact that slavery should vary between wide limits or vary at all during the historical period is evidence that it is tentative, and not inherently permanent in human nature.

The life of the individual is the epitome of the race, and there is no reason for thinking that any portion of the human race has as yet reached maturity. The child, in struggling to learn, frequently gets itself into a tangle, which it makes worse by violent outbursts of temper. Similarly, the race, as instinct has ripened into intelligence, has tried experiments and developed errors. These were made innocently enough, and the consequences for long have been attributed to the wrong cause. It is in this way that humanity drifts into slavery, which is intensified by outbursts of physical and moral violence.

\section{Primæval Man.}

Early man lived much as socially inclined animals live now, and, contrary to popular belief, he was not a cannibalistic savage thirsting for human blood. He possessed all the common humane attributes, which are inherently his for all time. He took pleasure in the society of his fellows and felt sympathy towards them exceeding in degree that shown by any species.

This sympathy was not confined to human kind, but extended itself to the love of other animals in an exceptional degree. Probably the earliest expression of his love of animals was the domestication of the dog, bred from wild species, wolves and jackals (canis), and foxes (vulpes). This old friend of man assisted him in hunting and in the defence of the women and children against the attacks of the larger carnivora.

In the herd, school or pack there are leaders possessing more than ordinary inceptivity, skill and strength; so among the tribes of men there were natural leaders, chosen with unanimity, who, as individuals, had equal opportunity with the others, but who captained the co-operative activities of their fellows.

A leader does not require to be either a slave-owner, "owning" the persons of his followers, nor a landlord, 
" owning" the land upon which they exist. Indeed, when slavery enters into the function of leadership, the latter becomes perverted so that the advantages of close cooperation are lost in jealousies. Healthy emulation is destroyed because the reward of industry is confiscated.

Just as the Cossacks of the Ural, the Nigerians of Northern Africa, and within recent times the highlanders of Scotland and the peasants in parts of Europe out of contact with Roman jurisprudence, looked upon land as in the same category as air, and as Western peoples do not credit ownership of persons as chattels, so primæval man had no false sense of ownership in either.

\section{How Man drifted into Slavery.}

Caves and other natural shelters might be shared by many families, and huts, when man learned to build them, would probably be constructed by little communities and properly regarded as the joint property of each community. Simple tools made by individuals would be owned by those individuals, so that even from early times there would be a belief in common property belonging to the clan, as well as in private property, made the subject of barter as between individuals.

It may be conjectured that the domestication of the dog did not lead to any confusion as to ownership, because a dog attaches himself definitely to one person before any other, although he may graduate his affection and differentiate between those with whom he associates. It is, however, easy to understand that when man proceeded to domesticate the sheep, the goat and the ox, confusion might arise out of which contention and unhappiness resulted. To obviate this in so small a community, it is probable these chattels would also be regarded as common to the tribe or clan.

Man had now entered the transition stage from hunting to pastoral habit, and the size of the community would increase. While for the family, or group of families all related, sharing-in-common would be an amicable arrangement, experience shows that there comes a limiting period when the social system becomes unstable, and tyranny is necessary to delay outbursts of anarchy. 
It is axiomatic that everyone seeks to gratify his desires with the least possible exertion. It is also axiomatic that self-interest is the dynamic force motived by man's pursuit of happiness and that man is never satisfied. Thus, under free and just conditions it follows that there would be constant progress, but no undue exertion would be expended to obtain it.

The head-man or chief elected by the general consent of the clan would find, as numbers increased, that his responsibilities began to encroach upon his happiness, and he would become leader of a council of heads of families, who would assist him to preserve order. In this we discern the rudimentary State based upon force. A crisis had been reached, where the function of management was in danger of being exaggerated into the monopoly of ownership in flocks and herds, individuals, in order to facilitate control, being prevented from owning their own. Compulsory communism is the first step to absolutism, and it always arises through confusion in ownership.

When an individual, or voluntary co-operation of individuals, or family is unable to retain the reward of its endeavour, to keep, to give away, or to exchange fairly and freely with others, strains are set up in society and trouble is inevitable. Instead of gratifying desire with the least possible exertion, some seek to take advantage of the rest by withholding exertion, and others are imposed upon.

Industry is discouraged and freedom of choice is interfered with. Poverty takes the place of plenty. Deceit and cunning substitute willing co-operation in communism based upon force, which is always supported by plundering the industrious. At all times, and upon any considerable scale, attempts at sharing-in-common have ended in failure and disappointment. The early Christians, who reverted to communism, when they grew in numbers failed to destroy self-interest by putting to death Ananias and Sapphira.

Communism by coercion failed after the French Revolution, and the recent experiment in Russia ended disastrously, caused not by external interference, but owing to internal trouble, created through failure on the part of the citizens to distinguish between what was rightly the 
property of the community and separately that of the individual.

\section{Primitive Communes.}

In isolated localities upon the globe there yet exist primitive communistic tribes, and their condition is everywhere the most wretched and least progressive known unless we include the slum-dwellers of modern towns and cities.

The Fuegians are physically and mentally of good capacity, but they do not progress because they have not learnt to respect individual rights. As an example of the length to which this is carried, Darwin relates how, when a native Fuegian was given a piece of red cloth, it was confiscated and carefully torn up into small equal squares for each member of the clan, which rendered it quite useless.

Infanticide, cannibalism and the brutal slavery of women characterise the custom of all peoples whose philosophy of ownership has not advanced beyond the stage of coercive communism. Mutual robbery leads to universal poverty, and the children and the aged are frequently forsaken. Fuegian tribes are continually at war, each labouring under the delusion that the other is responsible for the calamity that error has brought upon all.

" They cannot know the feeling of having a home, and still less that of domestic affection; for the husband is to the wife a brutal master to a laborious slave. Was a more horrid deed ever perpetrated than that witnessed on the west coast by [Admiral] Byron, who saw a wretched mother pick up her bleeding, dying infant boy, whom her husband had mercilessly dashed on the stones for dropping a basket of sea-eggs? How little can the higher powers of the mind be brought into play; what is there for imagination to picture, for reason to compare, for judgment to decide upon? To knock a limpet from the rock does not require even cunning, that lowest power of the mind. Their skill in some respects may be compared to the instincts of animals, for it is not improved by experience ; their canoe, their most ingenious work, poor as it is, has remained the same, as we know from Drake, for the last two hundred and fifty years." (Darwin.)

Nevertheless, Darwin showed that, when placed even 
for a short time in a freer atmosphere, selected Fuegians were capable of astonishing advancement, just as on a larger scale the New Zealanders and Fijians have absorbed a higher culture.

The effects of collectivism, or indeed any form of captivity, are similar in any part of the world. The communistic Fijians in the Southern Pacific, living in a climate which is that of a veritable Garden of Eden, exhibit the same symptoms as do the Fuegians, who live in a climate where the sun is rarely seen.

It is not necessary to trace in detail all the logical steps leading to the consequences which result from an erroneous attempt to secure equality of opportunity by means of communal conscription. All forms of slavery, whether of man's person or through his surroundings, have their root in compulsory communism, which is the negation of equality of opportunity.

\section{The Pastoral Patriarchs.}

We may conjecture that in groping for means with which to repress anarchy, inevitably resulting from the interference with the natural right of the individual to dispose of his own labour products according to pleasure, the chief would seek to add to his authority and power, and he would be supported in this by the clan, most of whom at any given time desire to live peaceably. Unable to discern where they had gone astray, coercion would appear to them to be unavoidable.

The chief would soon be recognised as the trustee for the tribal property, and a short step would lead to virtual possession. At the death of the chief the head-men would at first elect a successor from among themselves, but increasing oppression of the clan would lead to the formation of factions, and contention would necessitate the adoption of a succession of chiefs, which would ensure a smooth transition. Experience of crises would lend foresight in avoiding trouble, and the custom of appointing a successor during the lifetime of the reigning patriarch would grow up. The choice would tend to be invested in a relation of the patriarch, frequently a son or a daughter. Hereditary succession would follow as a consequence. 
At first ruler and priest or adviser in one, a differentiation of these functions took place, and side by side with the rulers there grew up a privileged caste of oracles, judges or witch-doctors. Nativity, marriage and death were the pivotal mysteries round which this "trade union" or professional society wove their superstitions to enclose a credulous people. Priestcraft has always been the prop of constituted authority, sometimes delaying disaster, sometimes delaying progress.

As an agent of inertia the hereditary principle was found to be most effective, and the incestuous custom of brother and sister uniting in marriage was not an uncommon one. Among Aryan tribes it was customary for the new ruler to marry the widow of his predecessor for the better substantiation of his claim to reign, and this custom persisted even when father-to-son succession had become more usual.

From nominal possession of the tribal chattels it is easy to see a development into complete ownership, with power in the hands of the once trustee leader to dispose, and even at pleasure to withhold, the common property of the tribe. Raised by monopoly power high above his fellows, the chief and his court would be the arbiters of life and death. Opportunity would be unequal and the clansmen would become subjects.

Out of necessity, owing to shortage caused by the killing of males in battle, women as wives and concubines would submit to be herded in harems, presently accounted property and commodity to be given away and exchanged. Children would be born into slavery, and thus male slaves as chattels would be reared. Among the Maories it was the custom for almost every girl in New Zealand who was pretty or promised to be well-favoured to be tapu for some chief. The Kaffir chiefs also exercise the same privilege, and we have some evidence in the ancient law of Gavelkind that a similar custom was common in Feudal times among ourselves.

\section{The Antagonism of the Shepherd and the Hunter.}

The free hunting and fishing tribesmen might long hold out against these developments, but the bulk of the com- 
munity would be pastoral, relying upon the herds for their subsistence, desire being satisfied with less exertion. Selfinterest in the case of the shepherds being directed into desire to dominate each other, they would seek in due time to dominate their neighbours. We are now in a position to understand the dislike of the patriarch and the slaves for the more independent hunters, who were regarded as outlaws, and the story of Esau and Jacob of the Old Testament possesses a new interest.

In encounters with these hunters, skilled in the use of weapons, the patriarch and his enervated bondsmen would often be overcome, the victors taking the place of the former slave-owners to apply their suction to the existing channels formed in the customs of the community. The free men would thus become emmeshed in the slave system. We may expect that such masters would develop military preparedness, and there would be emulation in armaments. Remembering the success of their skilled attack, the new masters would seek to add to their glory and fancied security. Schemes of conquest over other tribes, to coalesce them into greater power for still further conquest, would readily occur to the ancient Attilas.

Herein we see the beginnings of organised warfare among mankind.

\section{Polyandry and Polygamy.}

Where coercive communism has been carried to an extreme, the horrible custom of infanticide, associated with abortion, incest and sexual perversion, is very common. For economic reasons there is great mortality among girl babies. The consequent unbalance of sex numbers leads to the practice of one woman having several husbands, known as polyandry, which frequently breaks down into the institution of so-called communal marriages, when intercourse becomes utterly licentious and promiscuous.

Polygamy, or several wives to one husband, distinguishes the patriarchal system of centralised slavery, and the effect is the same in many ways as that which results from female infanticide. While not so degrading as the institution of polyandry, polygamy is a fruitful source of anarchy, the law of battle becoming perverted into the lawlessness of necessity. 
It is obvious that although a protracted war may cause a temporary shortage of males, the tendency is for the sexes to regain their balance as time goes on. Assuming that polygamy had been instituted during a period of hostilities and retained because it was thought to be an advantageous arrangement for everyone, the women included, it is easy to see that many unattached males would grow up afterwards. The younger generation would, of course, have been taught to look upon polygamy as a divine institution, and it would be perpetuated.

When confusion of ownership arises in what is private property, it appears to be inevitable for property rights to be vested in what, in the nature of things, cannot be owned. As women were bought and sold, the monopoly of the profiteer patriarch would intensify, because the young men would be at a disadvantage in the market. It can thus be understood that resort would be made to violence and that raids for women would take place.

\section{An Example from the Bible.}

With the possible exception of the period when some approximation of the Mosaic land laws was in operation, the story of Ruth indicating a bright interval, the status of the woman was never very high among the ancient Israelites. Even in the Decalogue the wife is included among the chattels, and towards the end of the commonwealth or commune the institution of polygamy was general.

In the Book of Judges a classic example of civil strife brought about by the slavery of women is recorded. The inciting incident to the outbreak was a revolting outrage perpetrated by a roving band of young Benjamites upon a Levite's concubine in Gibeah.

Before the battle, the tribe of Benjamin having refused to hand over the murderers to justice, the other Israelitish tribes had taken a vow to withhold their daughters as wives to the offending tribe.

This trading restriction was evidently considered a very severe reprisal by all, for in great remorse, after the battle, in which all had suffered heavy losses, they joined forces and attacked in combination their kinsmen of 
Jabesh-gilead, who had not responded to the horrid missive of the Levite.

Men, women and children of the unoffending people were massacred, and only four hundred virgins were saved alive. These were awarded to the Benjamites, " and yet so they sufficed them not." The children of Benjamin were therefore advised to lie in wait in the vineyards and " catch every man his wife of the daughters of Shiloh" as they danced at the feast.

In this quaint old Bible story there is no indication that the chronicler regarded polygamy as an unjust system, still less that he realised that the disorderly condition of the country was brought about because the Israelites had a faulty philosophy of ownership.

$\mathrm{He}$ evidently considered that the anarchy existed because the people were not governed firmly enough. "In those days there was no king in Israel; every man did that which was right in his own eyes."

His error is a common one at the present day, in spite of the abundant lessons of the past. As a matter of fact, the regal period of the Hebrews was a stormier one than that of the commonwealth. 


\section{GHAPTER IX}

\section{THE ORIGIN OF EVIL}

\section{READER'S GUIDE}

ChAPTER IX describes how communities drift into slavery when the property of the individual is confiscated in taxes upon production, and when the rent of land which is common property is confiscated by private persons. The lessons are taken from the ancient Egyptian and Accadian civilisations.

\section{The Headings are :}

Early Civilisations founded in Freedom-The Yeomanry of Egypt-How they drifted into Error-The Deterioration of the Credence of the Egyptians-The Profiteer Priesthood-Centralised Government established to enforce Peace-The Collapse of the Old Empire-The Middle Empire-The Era of Wars upon a Grand Scale begins-The Two Varieties of Captivity-Joseph's "Corner"-The Husbandmen overreach themselvesThe New Empire-The Decline and Fall of the New Empire-Great Empires breed Little Men-The Origin of Evil. 
God made man upright; but they have sought out many inventions.-ECCLEs. vii. 29. 


\section{THE ORIGIN OF EVIL}

\section{Early Civilisations founded in Freedom.}

Wherever man has made any advancement in the arts and sciences, it is invariably found that progress results when social institutions afford approximate conditions of just and equal opportunity to citizens, and that retrogression takes place as the shortcomings of those institutions are magnified by the extended application of private and public enterprise, both of which grow in upon themselves and decay unless they are given more freedom by the readjustment of those institutions in the light of experience.

The ancient civilisations of Egypt and Mesopotamia, and in later times the offshoots of China and India, had their beginnings in comparative freedom for private and public enterprise. The Egyptians were a highly civilised people hundreds of years before the pyramids were erected, and had made immense progress in agriculture and engineering before the time of the Pharaohs.

It is among the more ancient of the buried works of art that evidences of the highest skill and culture are to be found. The written records of the remoter period reflect the most humane and informal spirit.

The status of the woman, that sure index of civilisation, was higher preceding the period of the third dynasty of the Old Empire, seven thousand years ago, than at any subsequent time. She had equal rights before the law, served in the priesthood, was the equal and companion of her father, brothers and husband.

\section{The Yeomanry of Egypt.}

The right of the individual to the fruits of his labour upon the soil, for obvious reasons, is less fraught with the 
possibility of confusion of ownership than where the community is nomadic and pastoral.

Security of tenure is necessary for the purposes of agriculture, and more especially when permanent improvements are needed in the shape of buildings. That security is not given by making a claim to the absolute ownership of the site occupied, but by the rendering to the community the equivalent of its social value, which value, being equally created, should be returned equally to citizens in common services such as roads, irrigation schemes and education.

It is probable that at the commencement the common services were provided by voluntary contributions of labour and materials, and that these were increased as the benefit from them was more and more felt. For long the condition of the husbandmen must have been one of peace and plenty for every homestead. In this environment of happiness a great civilisation was born. Many inventions were made not only in agriculture but in the hundreds of subsidiary activities.

\section{How they drifted into Error.}

At the time of which we write, although the law of rent would operate, its action would be obscure, and the husbandmen would be unaware of it. It was long in the history of the world before the rent of the land became recognised as a specific quantity, just as the exchange of goods was carried on by direct barter long before the laboursaving device of money-counters was used.

It would of course be apparent that with the same application of labour some lands raised a greater harvest than other lands, and that those in possession of the better lands would be expected to make proportionately larger voluntary contributions to the communal expenses, but the just measure not being recognised, the industrious and resourceful would tend to be penalised. Consequently, we may imagine that there were heartburnings and misunderstandings.

We may suppose that the husbandmen then appointed certain of their leaders or head-men to collect and to arbitrate, and deputed them to apportion the contributions. 
Although dimly conscious that it was not quite fair, in ignorance of a better method, they would resort as an experiment to the amount of the harvest obtained as the basis of assessment for the "equality of sacrifice."

But ignorance of a natural law does not render immune the offenders to the consequences of nonconformity. Although possessing at first sight a semblance of justice, the incidence of an income tax or tax upon production, apart from its arbitrary nature, is fundamentally unjust. It places a premium upon indolence, and it is evaded as much as possible by "Ananias and Sapphira."

"Ability to pay" is the basis upon which the bandit assesses the prisoner's ransom, and the unlimited State, like the bandit, tends to increase demand to the limit of inability to pay more. With no just measure of what is due to the community, a false principle is established that the State is entitled to take by force what it chooses from each citizen, and without obligation to make equal return.

Experience teaches that the complete enslavement of the labourer of hand and brain is only a question of time when the doctrine is accepted of divine right of the State to rob the producer. In adopting the income tax the Egyptians had inserted the thin edge of the wedge of coercive communism.

\section{The Deterioration of the Gredence of the Egyptians.}

It is remarkable that the economic condition of the community has its reflex in the changing of religious beliefs. When the ideas of a people become entangled in daily matters of production and exchange, religion breaks down into superstition, but as a state of equal rights and equal duties is approximated, so ignorance is dissolved by knowledge based upon truth.

The earliest records of the Old Empire afford evidence that the ancient Egyptians possessed religious beliefs which compare favourably with those of the best period of Judaism. "In their moral law the Egyptians followed the same precepts as the Decalogue (ascribed to Moses two thousand five hundred years later), and enumerated treason, murder, adultery, theft and the practice of magic as crimes of the deepest dye." (Birch.) 
According to the Todtenbuch, or sacred book of the dead, God is "the only one Being, the sole Creator, unchangeable in His infinite perfection, present at all time, past and future, everywhere and yet nowhere."

But just as the accredited nature of Yahve or Jehovah advanced, following the economic progression of the Jews, from the status of one cruel war-god among many other tribal deities, until $\mathrm{He}$ became the Supreme God reigning alone in justice and mercy, so conversely the conception of the Egyptians fell from this high estate, and was shattered into powder as the Egyptians got their philosophy of ownership into a tangle.

The tax-gatherers, who were also teachers and servants of the public, in time and upon occasion became their priestly masters. Under the cloak of benevolence, which deceived good-nature, the priests, taking advantage of the grateful feelings of the citizens, sought to increase the income tax upon various pretexts. Gradually trusteeship was exalted into possession and then virtual ownership of the revenues.

Disastrous consequences are bound to follow when equity in politics is supplanted by charity. Starting from a period when life was simple and cheerful, and in which both religion and art were more or less unfettered by superstitions and conventions, war being unknown, we now begin to find traces of that growth of parasitism which finally smothered all progress.

It is true that for long progress in invention and culture persisted, but as economic enclosure crept round the life of the people, advancement in the arts became only one of quantity. Originality and quality disappeared because they were accounted heretical in the thickening atmosphere of despotic priestcraft. Religion, turned from its office of elevating man, was slowly decomposed into superstition for keeping him down.

Horsheshu, e.g. servants of Horus, were appointed to control the priesthood, and these chief priests ruled from each independent city and temple forming the centre of a nome or province of Egypt. It was to their interest to complicate theological beliefs and surround themselves with mysteries. 
It was taught that, although one in essence, God was not one in person; that $\mathrm{He}$ existed as Father, but reproduced Himself under another aspect as Mother, and under a third as Son. "This Trinity is three and yet one, and has all the attributes of the one-infinity, eternity and omnipotence. Thus far the Athanasian Creed might be a chapter of the Todtenbuch, and it is very evident where the Alexandrian saint got those subtle metaphysical ideas which are so opposed to the rigid monotheistic creeds of Judaism and Mohammedanism." (S. Laing.)

Just as in Christianity the Virgin, the saints, and even the images and relics became objects of adoration, so likewise the Egyptian trinity became infinitely extended. To the Father, Mother and Son were admitted a daughter and other descendants.

In the original Cosmogony the sun was described as having been called into existence by the word of the Supreme God, but it came to be taken as His visible representative, and finally worshipped as a god itself. Each different phase received a different designation, e.g. Horus when on the horizon, rising and setting, $\mathrm{Ra}$ in its midday splendour, Osiris during its journey in the night through the underground world of darkness. These were personified and worshipped separately, and it is significant that while Horus was at first the most popular, Osiris became at length the favourite, as the tomb and a future life increasingly occupied the thoughts of the unfortunate people.

The Egyptians extended the process of dissociation, and they soon filled a whole Pantheon with secondary gods, either personifications of different attributes of the Supreme God or separate portions of the One Divine Essence. The personifications came to be regarded as independent beings ; to have a female principle or wives added to them, and to be worshipped as the patron gods of the respective temples in precisely the same way as the patron saints of the kingdoms of Christendom thousands of years later.

Furthermore, fragments of the Divine Essence were supposed to be incarnated in the high-priest Pharaoh and his family, and even in bulls, cats and other sacred animals. Everything possible was done to create a web of hypnotism 
for the enslavement of the Egyptians to a centralised hierarchy.

\section{The Profiteer Priesthood.}

As the social environment of the Egyptians advanced in malignity, their pious hopes were more and more fixed upon a future life. They regarded their houses as merely temporary inns and their tombs as their true permanent homes. Every activity became subordinated to the preparation of the abode for the mummy and its $\mathrm{Ka}$ or second, shadowy self, against the time when the soul would have to appear before the supreme judge Osiris and the fortytwo heavenly jurors.

It was believed that so long as the receptacle for the $\mathrm{Ka}$ and the occasional visits of the soul was preserved, conscious personal life was continued beyond the grave, otherwise the ghostly entities might perish also, or be left to flit through the world of shadows without a home or name. Hence the extraordinary care and expense lavished upon the provision of a fitting tomb and mummy.

Just as it is the ambition of the modern profiteer to accumulate a great fortune, to become a landowner, and "found a family," so the Egyptian prototype sought to determine labour to the construction of the most permanent tomb possible and so to ensure the preservation of his after-life existence.

In the Sacred Book of ancient Egypt there are evidences that the Egyptian prophets attempted to restrain the selfishness of privileged persons, as, for example, those in possession of irrigation works, a monopoly in such a country as potent as a railway in, say, America. The ideal prayer of the soul pleading on the day of judgment before Osiris and the Celestial Jury contains the following articles :

"I have told no lies; committed no frauds; been good to widows; not overtasked servants; not lazy or negligent; done nothing hateful to the gods; been kind to slaves; promoted no strife; caused no one to weep; committed no murder; stolen no offerings to the dead; made no fraudulent gains; seized no lands wrongfully; not tampered with weights and measures; not taken the 
milk from sucklings; not molested sacred beasts and birds; not cut off or monopolised watercourses; have sown joy and not sorrow; have given food to the hungry, drink to the thirsty, and clothed the naked."

"I am pure, I am pure."

These counsels of moral perfection, like those of Buddha and Zoroaster, of Christianity and of Islam long afterwards, had a restraining effect upon exaggerated selfinterest, but in common with modern religions, the Egyptian moral code, as the people succumbed to captivity, was also glossed and waxed over, until hypocrisy and perfunctory charity deadened the conscience of the wrongdoers, and brilliant success in wrongdoing dazzled the eyes of the victims.

Indeed, the worst offenders were the Chief Priests themselves, just as in more modern times, given the opportunity, Christian popes, cardinals and bishops practised themselves, and condoned in powerful rulers, the very vices which offend against Christian principles.

\section{Centralised Government established to enforce Peace.}

Recent investigations go to show that the growth of the contemporaneous civilisation of Chaldæa in Mesopotamia was proceeding by similar steps to that of Egypt. The Horsheshu of Egypt and the Patesi of Chaldæa became hereditary castes, and while each hierarchy developed a different system, the Accadian being more astronomical, the political symptoms were identical.

The recently discovered statues of Sirgalla, corresponding to the same early period as that of Chephren and carved out of the same diorite, only to be found in the peninsula of Sinai, is an indication that commercial intercourse by sea existed between the ancient Accadians and Egyptians, which apparently disappeared as the engendered feelings of suspicion and hatred that always accompany enclosure brought about mutual exclusion and the closed door to peaceful trading.

Within each country the producers of the necessities of life had become heavily burdened to support the hordes of priests and slaves engaged in vain and useless pursuits. Stunted in the perpetual twilight of captivity, their minds 
suffered that most terrible consequence of subjection, the awful dread of the future and the unknown which oppresses alike the miserable savage imprisoned in a web of superstition woven by the witch-doctor and the cultured laity bewitched by the monstrous doctrines of religious inversion.

Not seeing the true cause of their misfortunes, intent only in pursuing the shadow for the substance, the mentally darkened provincials blamed each other.

Centred round the people of each patron god and hereditary priest-king, there sprang up egoistical parties composed of contending time-servers and persons benefiting from conflicting vested interests. Civil commotions caused by the factions became frequent, and to obtain dynamic stability, the successful faction for the time being directed the attention of all to a struggle for supremacy with adjoining provinces.

One province became subject to another, and alliances were entered into for mutual security of the ruling priests. The fighting, which at first was not of a sanguinary nature, gradually became more serious as bitterness intensified and the Egyptians got familiar with and skilled in the taking of human life.

In the course of time a state of temporary equilibrium was attained, when the two divisions of Upper and Lower Egypt were united in an imperialistic league or coalition under Menes, the High Priest of Ra, i.e. Pi-ra or Pharaoh, pre-eminent above the priesthoods of Horus and Osiris, as is the sun most glorious at its meridian.

Now was established at Memphis a reign of centralised government to enforce peace throughout the whole land of Egypt, and it is noteworthy that almost contemporaneously the Semite Sargon the First founded a united monarchy at Agade, the capital of Accad, or Upper Mesopotamia, an Empire extending southwards over the alluvial deltas of the Euphrates, Tigris and other rivers which flow into the Persian Gulf.

\section{The Collapse of the Old Empire.}

It is an eloquent testimony to the organised efficiency of the slave system built up on the credulity of the masses 
that the Old Empire lasted almost fifteen hundred years. Power in the hands of the Pharaoh and the priests was successfully created for the repression of rebellion at a greater rate than the resistive or disruptive social forces mothered by the unquenchable desire for freedom.

It was during this epoch that the greatest monuments, including the pyramids, were constructed by the industrial conscription of the unemployed, great armies of disciplined slaves being fed and supported by heavy taxation of the husbandmen. But useful hydraulic engineering schemes of irrigation were also carried out, and Egypt became the granary of the surrounding countries. For some centuries the rigidity due to acquired momentum kept alive a hectic prosperity.

"They built like giants and finished like jewellers," but anything new and fresh was rarely attempted. In the industrial and fine arts a degree of skill in execution was reached which has never been surpassed. It was a barren culture, directed not to the service of the living, however, but to the dead. There have never been such lasting memorials to human folly.

The distribution of the good things of life was unbalanced at the source by monopoly power. The obliquity of the platform of thought and custom increased as the weight of privilege bore down upon the struggling masses, who were gravitating towards misery and squalor.

As the rich became richer and the poor became poorer, society stratified into hereditary castes. A perfection of refinement and the polish of learning were preoccupations of the leisured priests, who imagined themselves far removed from the common herd condemned to penal servitude for life.

Nevertheless, the dry rot of slavery was in the foundations.

In accordance with the law that freedom is an essential condition of permanence, governmental power at length became powerless to preserve the social order. There was a rapid decline, and a cataclysmic fall into utter impotence and anarchy. A period supervened in which all records were eclipsed. 


\section{The Middle Empire.}

"When Egypt, with the eleventh dynasty, awoke from its long sleep, the ancient traditions were forgotten. The proper names of the kings and ancient nobility, the titles of the high functionaries, the style of the hieroglyphic writing, and even the religion, all seemed new. The monuments were rude, primitive, and sometimes even barbarous, and to see them one would be inclined to think that Egypt under the eleventh dynasty was beginning again the period of infancy which it had already passed through fifteen hundred years earlier under the third." (Mariette.)

Out of the chaos of coercive communism and indiscriminate anarchy there had grown up a new absolutism, now known as the Middle Empire, which was crudely held together by militarism and robbery. Surrounding nations were made tributary, and the frontiers were extended far to the south over Nubia, the Soudan and Southern Syria. The capital was no longer at Memphis, but at Thebes.

All cut-throat empires are short-lived, and the Middle Empire, which was one of the earliest attempts to enforce peace by methods of organised ruthlessness and frightfulness, was no exception to the rule.

Egoistic systems live dangerously, and, actuated by motives based upon fear, it is their habit to enter into fickle coercive alliances for protection. The continuance of the coalition depends upon the sustained prosecution of plundering conquests, and since a limit is reached at some time, beyond which the returns decrease at a greater rate than the sacrifices, there is a stage where the system loses stability.

At this point the allies proceed to quarrel over the division of the spoils, that always melt into disappointing compass when they are in their clutches. While they fight and prey upon each other, it frequently happens that some smaller outside or barbarian tribal egoism, probably smarting from the effects of punitive expeditions, watches its opportunity, reacts, and captures the control centres of the empire.

The civil wars and commotions which attended the fourteenth dynasty prepared the way for a great catastrophe to the Middle Empire. 


\section{The Era of Wars upon a Grand Scale begins.}

A similar development had taken place in far away Mesopotamia, which was divided into antagonistic provinces.

About 2280 B.c. the Elamites, who lived on the eastern shore of the Persian Gulf in the country of Elam, descended with their new invention of regular troops upon their kinsmen of Chaldæa, conquering and ousting the existing Semitic dynastic rulers.

From this time a succession of wars of swaying conquests followed each other; it was the inauguration of the militarist age upon the grand scale.

The success of the Elamites in so easily overcoming their neighbours by the aid of picked trained men, skilled in killing, gave an impetus to invention in the "art of war." Each province in Western Asia adopted a standing army, and all important cities were walled for defence. The priest-kings struggled for supremacy with each other under the ægis of their patron god in the same way that Christian princes three thousand years later, in the age of chivalry, led their followers under the banners of their respective patron saints in wars with each other and in combination against Islam.

The pastoral clans of Arabia and Syria, hearing of the success of the Elamites, became infected with the new form of adventure, which seemed a cure for their own domestic troubles. They joined forces under shepherdkings to prey upon the empires of the fertile deltas, rendered helpless by internal dissensions.

The Hyksos found the Middle Empire, which was demoralised by parasitic growth, an easy prey. After a short period of fire and sword, the empire fell into their hands like rotten fruit. The shepherds quickly adopted the manners and customs of the Egyptians, who became their hosts, to the vexation of the native parasites.

\section{The Two Varieties of Captivity.}

It is scarcely necessary to remind ourselves that slavery of the extreme chattel variety is not a state accomplished in one step, but is evolved by many gradations of control. Just as the capture of an animal can be effected quickly when he has only to be caught in an enclosure, so once a 
community has become enclosed within a net of erroneous custom, the remaining shreds of its freedom may be easily divested and the yoke of bondage imposed.

Preserved in the Book of Genesis, the legendary story of Joseph exemplifies how the yeomanry of Egypt, believing that the earth could be bought and sold, were themselves sold to Pharaoh.

Joseph, it will be remembered, had been sold into slavery by his brothers, jealous of the patriarch's favour and enraged by the encouragement given to Joseph in his dreams of ascendancy over his brethren. He was fond of power, spoilt by an old father and accustomed to the idea of one man owning another. In his eyes the comparative liberty of the Egyptian husbandmen must have appeared incongruous, and this view was no doubt shared by the reigning Pharaoh, if, as is probable, he was a Hyksos or Shepherd-King.

From the story of Cain and Abel we gather that there was antipathy between the tillers of the ground, who built cities, and the keepers of sheep, who lived in tents. We also read, "Every shepherd is an abomination unto the Egyptians."

The cause of this hostility probably had its origin in trading asperities due to profiteering. The husbandmen, in virtue of their false status as "owners" of the soil, were enabled to keep the market short by throwing land out of cultivation, and they were thus obtaining high prices for their niggardly production. Surrounding pastoral tribes would suffer for this, as well as their own countrymen.

\section{Joseph's "Corner."}

If the tillers of the soil had been assessed for the common services upon the rental value of the land held by them, whether used or unused, instead of being penally taxed according to production, they could not have kept land idle without ruining themselves. Consequently there would have been profuse production, in which case it would have been impossible for Joseph to have made his "corner." It thus happened that the institution of private property in land, which the peasant proprietors most likely imagined was their charter of liberty, was the cause of their undoing. 
There were no newspapers for the purposes of propaganda in those days, but the priesthood were very influential in forming the "correct atmosphere." The thoughts of the superstitious Egyptians were conveniently guided by occult signs, such as the dreams of kings.

Pharaoh was understood to dream that seven fat kine preceded seven lean kine from the river, and that the latter cattle ate up the former. This was confirmed by a similar dream in which seven ears of good corn were consumed by seven ears of poor.

The king found Joseph more resourceful than the native wise men: possibly the dreams were suggested by him at an opportune moment. The interpretation, which was that seven years of good harvests should precede seven years of dearth, certainly seems an obvious one.

For his prescience in foretelling the future, Joseph was made prime minister of Egypt, with the power of .a despotic Food Controller and President of the Board of Agriculture rolled into one. Officers were appointed over the land, and a fifth part of the produce was taken up in the seven plenteous years. "And the plenty shall not be known in the land by reason of that famine following; for it shall be very grievous.'

Persuaded that it was necessary in the national interest to produce more, the Egyptian husbandmen brought land back into cultivation and exerted themselves to obtain good harvests. While in the Biblical sense seven years may simply mean a certain unascertained period, it is possible that, influenced by patriotic feelings based upon credulity kept alive by Pharaoh's officers, the period was as much as seven years.

Although the annual Nile floods do vary so as to effect the volume of harvest, they never do to the abnormal extent to be inferred from the narrative; nevertheless, it is reasonable to suppose that the transient feelings aroused would wear away, and, discouraged by the Government confiscation, the Egyptians would lose heart. They would begin restriction of output so soon as a partial failure of the inundation occurred to confirm the prophecy, apart from a desire to recoup themselves in higher prices.

The famine then began, "and the seven years of 
plenteousness that was in the land of Egypt were ended. And the seven years of dearth began to come, according as Joseph had said; but in the land of Egypt there was bread."

In the meantime Joseph had made his "corner," "and Joseph gathered corn as the sand of the sea, very much, until he left numbering, for it was without number."

\section{The Husbandmen overreach themselves.}

Joseph waited until the Egyptians, attracted by the rising prices, sold out to the surrounding pastoral tribes, who were the first to feel the pinch. To such an extent did the Egyptians profiteer that they left themselves with insufficient food to sustain their families and to sow the land for the next harvest.

When the Egyptians realised their plight they sent a deputation to Pharaoh, who told them in effect "to trust the Board of Agriculture." "And when all the land of Egypt was famished, the people cried to Pharaoh for bread, and Pharaoh said unto all the Egyptians, 'Go unto Joseph, and what he saith to you, do.'

Joseph opened the storehouses and sold back to the people what had been taken from them with their consent, given in the belief that the State is entitled to tax what it likes. First of all he obtained all their money, which was soon used up. When money failed, he took their cattle in exchange, which were handed over to Pharaoh.

"They came unto him the second year, and said unto him : 'We will not hide it from my lord, how that our money is spent; my lord also hath our herds of cattle; there is not ought left in the sight of my lord, but our bodies, and our lands.

"'Wherefore shall we die before thine eyes, both we and our land? Buy us and our land for bread, and we and our land will be servants unto Pharaoh; and give us seed, that we may live, and not die, that the land be not desolate.' "'

Joseph thereupon "nationalised" the land of Egypt by purchase. $\mathrm{He}$ also socialised the means of production. "Then Joseph said unto the people: 'Behold, I have bought you this day and your land for Pharaoh: lo, here 
is seed for you, and you shall sow the land. And it shall come to pass in the increase, that you shall give the fifth part unto the Pharaoh; and four parts shall be your own, for seed of the field, and for your food, and for them of your households, and for food for your little ones.'"

The starvation manufactured by the tearful superprofiteer more effectually breaks the spirit of the freeman than the whip of the cruellest taskmaster. "And they said: 'Thou hast saved our lives: let us find grace in the sight of my lord, and we will be Pharaoh's servants.' "'

There was ruthless and thorough conscription of productive labour and unsparing extirpation of the "idler." The Egyptians were organised for peace upon the same lines as for war. A process of "combing out" was put into operation, and all that could be spared from agriculture were compulsorily removed to swell the armies of city slaves, the remainder sinking into the condition of the Indian ryot of to-day. "And as for the people, he removed them to cities from one end of the borders of Egypt even to the other end thereof."

The "aristocracy of intellect" of Egypt, the priests, were rewarded for their loyalty to the State of Divine Right: "Only the land of the priests bought he not; for the priests had a portion assigned them of Pharaoh and did eat their portion, which Pharaoh gave them; wherefore they sold not their lands."

It was the inferior philosophy of the Egyptians which levered them into bondage and kept them there. They believed that land could be bought and sold, and that the State, being entitled to tax what it liked, had therefore an unassailable right to their person.

Man must either progress or retrogress. The happiness of communities not being determined by the possession of things that money can buy, but by the extent to which their conduct conforms with the Will of God, it follows that evil consequences increase in volume so long as communities continue to move in opposition to that will.

In proportion as the enslaved producers of Egypt resorted to restriction of wealth output, so the profiteers increased their rate of plunder. It is roughly estimated that one-third share of the communal slavery fell to Pharaoh 
and his household, one-third to the priesthood throughout the land, and the remaining one-third to the masses.

\section{The New Empire.}

It was then that a sudden great fury took possession of the nation, and this was directed against the Hyksos rulers. They were expelled about I750 B.C. and their places were occupied by native tyrants.

Blind to the fact that their wretchedness had originated in an elementary injustice, which was within their power of righting, the Egyptians thought the lesson of experience lay in the subjugation of others as they had been dominated by the Hyksos.

Campaigns in Asia were proceeded with on a great scale, until the borders of the New Empire extended from the Persian Gulf to the Black Sea and the Mediterranean, and tribute was received from Babylon and Nineveh.

The empire of the sword lives dangerously. Power becomes more unstable as it grows into greater dominion, because might is not right. A reactance of hostility builds up, and after a while increases at a greater rate than the acquisition of power by the reigning regime. The empire of the sword perishes by the sword, and the new militarist administration is overcome in turn or collapses upon itself.

There is no progress by violence, because it is not the Will of God.

\section{The Decline and Fall of the New Empire.}

The Turanian Hittites, who founded an empire in Asia Minor, strove and wasted themselves against the Egyptians, but as their power declined that of Assyria arose. By merciless butchery, under the patronage of their cruel war-god Assur, the Assyrians hacked through Syria and Palestine to the Delta of the Nile.

The New Empire was not only stripped of the plunder of former conquests, but Egypt itself was invaded, and for some time became tributary to the victorious Nebuchadnezzar.

During the subsequent struggles of the imperialists for supremacy the Egyptians became in turn the slaves of 
Persia under Cambyses, of the Greeks under Alexander and the Ptolemies, and at the time of Cleopatra entered the bondage of the Roman Empire.

\section{Great Empires breed Little Men.}

It is difficult to realise at first that a denial of equal rights and equal duties, beginning almost imperceptibly, culminates at length in calamitous effects. It would appear that when we deviate from the path of Natural Discipline, the inexorable consequence is imprisonment or slavery, which is a hostile environment.

In this situation, instead of the State being for man, man becomes the property of the State; Governments, instead of being the servants of the people, become their masters; in place of Equality of Opportunity, there is Inequality of Sacrifice.

The Divinity of Man is destroyed when the State is endowed with Divine Right; Individuality is swallowed up by a soulless Egoism, and Principle is subjugated by Interest when the clay image of Superstition and Inhumanity is exalted in the place of the living vision of Humanity and Religion.

Great empires breed little men.

\section{The Origin of Evil.}

The neo-Malthusians and the teachers of hereditary taint have their counterpart in the Babylonian philosophers, whose theory was that as population increased "the wickedness of man was great in the earth, and that every imagination of the thoughts of his heart was only evil continually."

The myth of the Garden of Eden, the Temptation of the Serpent, the Trees of Knowledge and of Life, and the Fall of Adam, represented upon Babylonian cylinders and adapted in the Hebrew Bible, is an allegorical attempt to explain the mystery of evil in the world.

The imaginary conflicts between Good and Evil principles, between Ormuzd and Ahriman, or between God and Satan, are they not the hallucinations of captivity? In nature there are neither rewards nor punishments, there are consequences. Happiness and unhappiness are 
alternative consequences, depending upon conformity or nonconformity with the discipline of God or Nature.

In the Book of Genesis, and elsewhere in the Bible, there are layers of opposing sentiments by two distinct schools of ancient writers. One school taught that the " earth is the Lord's, and the fullness thereof," while the other held that the earth is the landlord's, to whom the fullness thereof was due for graciously permitting his fellows to live upon it.

The injunction " Be fruitful and multiply and replenish the earth" cannot be reconciled with the doctrine that the presence of evil in the world was due to original sin manifested in the instinct of reproduction, which doomed mankind to a heritage of pain and misery. "Unto the woman $\mathrm{He}$ said: 'I will greatly multiply thy sorrow and thy conception; in sorrow thou shalt bring forth children; and thy desire shall be to thy husband, and he shall rule over thee." "'

Failing to appreciate the relationship between man and his environment, the Patesi of Chaldæa, like the priests and presbyters of other ages, could not see that the earth had been reduced in dimensions by foolish institutions, and that in consequence its citizens had drifted into captivity. Deceived by the appearances of inherent evil in every direction, the priests fancied that God was hostile to His disobedient creation. "And unto Adam $\mathrm{He}$ said ... ' Cursed is the ground for thy sake; in sorrow thou shalt eat of it all the days of thy life; thorns also and thistles shall it bring to thee; and thou shalt eat the herb of the field, in the sweat of thy face shalt thou eat bread, till thou return unto the ground.'

The support of a host of militarist, political and priestly profiteers is the reason why the sons of Adam are born to sorrow. Labour in itself is not an evil, and the punishment of interminable servitude was not sent by a jealous, cruel God, but is a consequence of man's own social blunder.

The origin of all evil is superstition. 


\section{THE INSTABILITY OF PRINGIPALITIES AND POWERS}

\section{READER'S GUIDE}

Chapter $\mathrm{X}$ outlines the development of a truer religious conception, initiated by the prophets of ancient Judah and extended by Jesus of Nazareth.

\section{The Headings are:}

The Judaic Attempt to equalise Opportunity-The Arrival of the Israelites in Palestine-Mosaic Laws and Ordinances-The Credence of the Israelites in the Regal Period-The Judaic Land Reformers-The Jubilee Year-The Promise and Warning in the Book of Leviticus-The "Restoration"-The Story of Ezra and Nehemiah-The Maccabees-The Pharisees and Sadducees-The Ruins of Judaism-The New Prophets -The Kingdom of God upon Earth-Slavery and the Philosophy of Jesus-How to obtain Freedom-The Code of Jesus-The Political Economy of Jesus-The Unchangeability of the Commandments of God- "As ye Sow, so shall ye also Reap"- - He was Misunderstood, Despised and Rejected. 
In the eighth century B.c., in the heart of a world of idolatrous polytheists, the Hebrew prophets put forth a conception of religion which appears to me to be as wonderful an inspiration of genius as the art of Pheidias or the science of Aristotle.

"And what doth the Lord require of thee, but to do justly, and to love mercy, and to walk humbly with thy God ?" If any so-called religion takes away from this great saying of Micah, I think it wantonly mutilates, while if it adds thereto, I think it obscures, the perfect ideal of religion.-HUXLEY. 


\section{THE INSTABILITY OF PRINGIPALITIES AND POWERS}

\section{The Judaic Attempt to equalise Opportunity.}

It has frequently been remarked that history repeats itself, and this is to be expected, since similar national customs eventuate inevitably in similar consequences. "That 'evil communications corrupt good manners' is but an expression of the general law that human character is profoundly modified by its conditions and surroundings." (Henry George.) "This," says Emmanuel Deutsch—" this is the end of all investigation into history or art: THEY WERE EVEN AS WE ARE."

While "Institutions make men," despite differences in race, it is nevertheless true that men make institutions. In the history of every civilisation there is evidence of that progressive groping for a just basis upon which a civilised society can be built in which all persons shall have equal opportunity.

In the national history of the "Children of Israel" we have a unique narrative, showing how the rude invaders of Palestine of the legendary past progressed from a condition comparable with that of the half-savage Bedouins of to-day to a high social state.

\section{The Arrival of the Israelites in Palestine.}

The Amorites and the other older inhabitants of Palestine, which is about the same size as Wales, were more civilised than the invaders, but they had become enervated, living enclosed within a system grown out of erroneous practice. They had approached a condition resembling that which the Hebrews themselves reached in the regal period. The fenced cities were overcrowded with panicky citizens, and 
the depopulated, undercultivated country-side, producing insufficient food, created a more perilous position for the town-dwellers than for the ferocious herdsmen who attacked their fancied security.

The imprisoned, disunited cities fell one after the other into the hands of the Israelites, who murdered and plundered in the name of Yahve; but in time the country settled down, and the intruders intermarried with the Amorites, Midianites, Canaanites, Hittites and other tribes of Palestine. These names continued to distinguish the people, irrespective of racial mixture, inhabiting certain districts in which was a city or town containing a nucleus of the original dwellers who favoured some special deity.

The Israelites were polytheistic, like the people they lived among, and all joined frequently in the worship of each others' gods. Outstanding sores soon healed up, and although religious rivalries existed, there was never that extreme aversion between them and their neighbours which distinguished the sectarian Jews of later times, worshipping as they did the same one God.

The arrival of the shepherds had the effect of adding to the general prosperity. The country was partitioned out among their tribes, which brought it more into use, especially as they soon devoted themselves also to tillage. Their products were naturally exchanged with the inland towns and seaports, and there was thus created a condition of prosperity and security, which benefited all.

\section{Mosaic Laws and Ordinances.}

It is not definitely known to what extent the institutions said to have been established by Moses (as, for example, the periodic land divisions) were in operation. It is probable that the new-comers adopted the Chaldæan custom of one day's rest in seven from the original settlers along with more questionable practices.

What we do know is that the tribes fell into indiscriminate anarchy at the time of the Judges, and men banded themselves into factions for self-preservation. These unions of strength then fought each other for supremacy, and larger aggregations formed for the same reason, until there only existed two opposing leagues, one under Saul, who had been 
made king, and another under his rival David, who finally supplanted him.

\section{The Gredence of the Israelites in the Regal Period.}

Whatever may have been their philosophy of ownership when they struggled "to possess the land," by the time they reached the regal period the Israelites, like the older inhabitants of Palestine, believed that land could be bought and sold. In consequence, the rural parts of the country were again deserted, and the landless slaves in the overcrowded cities were ready to embark upon wars of conquest with neighbours.

The people lived precariously from hand to mouth and were subject to frequent outbreaks of famine and pestilence. They did not, however, at that time attribute these symptoms to wrongful social custom, but thought that the gods were angry with them because they had not completely exterminated defeated tribes, or because David had taken a census of the people.

While the rulers and the court had advanced in culture, "the beasts of the people" had sunk into a low condition of ignorance and servility. The imperialistic period of Kings David and Solomon was over, and the kingdom was splitting up into fragments, each of which became an egoism surrounding some local god, which the wise Solomon, in his day, had tactfully appeased by admission to the Temple at Jerusalem. There was now the inevitable reaction which comes sooner or later from oppressed tributaries, and these sought the aid of powerful neighbours like Egypt and Assyria.

\section{The Judaic Land Reformers.}

The prophets recalled the earlier days of a prosperous land "flowing with milk and honey," and saw plainly that the barrenness of the country and the misfortunes of the nation were alike attributable to large estates in few hands and land-withholding. Isaiah, the pioneer in the fight for freedom, does not temper condemnation of those "that join house to house, that lay field to field, till there be no place, that they may be placed alone in the midst of the earth," neither does the lion-hearted Micah spare the power- 
ful who "covet fields, and take them by violence: and houses, and take them away."

And "in the last days," when Justice with Mercy should be enthroned at length, Micah foretold, "They shall beat their swords into ploughshares, and their spears into pruninghooks : nation shall not lift a sword against nation, neither shall they learn war any more. But they shall sit every man under his vine, and under his fig-tree; and none shall make them afraid."

\section{The Jubilee Year.}

The reformers tried to remedy the dangerous state of affairs that had developed during the regal period by the institution of a Jubilee Year, which every fifty years should cut down parasitic growths. The slaves were to be set free, and the man burdened with debt was to be enabled to restart unencumbered.

In the laws attributed to the great lawgiver, Moses, land is regarded as a gift or loan, not to be bought and sold into perpetuity, "for the land is Mine." At the Jubilee Year the land was to be restored and a redistribution made to the original tribal holders, with certain modifications in the case of town sites.

The stranger in the land was to be included in the commonweal: "Thou shalt neither vex the stranger, nor oppress him ; for ye were strangers in the land of Egypt."

But the dream of the patriots was never realised. Before they died in prison or were put to death at the instigation of the profiteers, it is probable that the reformers had caused to be written a book containing their proposals, which Book of the Law was "discovered" in the time of Josiah, King of Judah.

\section{The Promise and Warning in the Book of Leviticus.}

In the Book of Leviticus there is a remarkable summing up of the good consequences which should result if the land were again put into cultivation and repopulated. They should eat their bread to the full, and dwell in the land safely. "None shall make you afraid-five of you shall chase an hundred, and an hundred of you shall put ten thousand to flight." The country would no longer harbour 
evil beasts. The desolation of the country would disappear, and its loneliness would be broken by the music of laughing children, the gladness of mothers, and the proud song of men whose bond had been lifted, so that they could walk upright.

But the warning should they depart from following the laws and ordinances is not less explicit. They should become stricken with disease, consumption and the burning ague " that shall consume the eyes, and cause sorrow of heart." Wild beasts should multiply and rob them of their children, destroy their cattle and make their highways desolate. Famine should appear, "And they shall deliver your bread again by weight: and ye shall eat, and be not satisfied."

In besieged cities they should become cannibals, to eat the flesh of their children. Frightened and crazed, they should fall upon and kill each other; the sound of a shaken leaf should cause them to flee when none pursued. Again they would enter the house of bondage, and they which hate them should reign over them.

This prediction was amply fulfilled in the calamities which befell the enclosed people.

The Israelites were first led away into captivity by the Assyrians, who took the fenced cities one after the other.

The Captivity of Judah followed afterwards by the Babylonians, a remnant being left with Jeremiah the prophet, who had lately been in prison, having incurred the wrath of the profiteer " that buildeth his house by unrighteousness, and his chambers by wrong; that useth his neighbour's service without wages, and giveth him not for his work."

\section{The "Restoration."}

The tribes of Israel were lost, nationally extinguished among similarly dispossessed slaves in the provinces of Upper Mesopotamia.

But the teachings of the prophetic idealists had left their mark of moral superiority upon the men of Judah. These gained the respect of their captors, and a portion returned to their native land, to be known as the Children of the Captivity. The remainder, who chose to be left in Babylon, preserved their individuality as the Jews of the "Dispersion" 
To an unknown extent the land was redistributed, and it is curious to note that history repeated itself, as the land again found its way into fewer and fewer hands.

The landless, at the mercy of the landed nobles and the priests, were cruelly exploited. In their necessity they accepted bare subsistence terms, which is everywhere the portion of the cheap slave, or they struggled hopelessly in the toils of usury.

\section{The Story of Ezra and Nehemiah.}

In the story of Ezra and Nehemiah we see how the self-consciousness of the Jews as a "Chosen Race" was promoted, and why their neighbours saw in them a "Peculiar People."

The Children of the Captivity, unlike the pastoral Children of Israel under Joshua, did not benefit the population economically. Spoilt in luxurious Babylon, they were consumers more than producers of useful wealth. The resources of the Remnant were stressed to support them when they settled in and around Jerusalem.

Under Zerubbabel, the governor, they proceeded to rebuild the Temple and the walls of the city, which aroused the resentment of the Remnant, who looked with scorn upon what they considered to be a vain undertaking. Zechariah, the prophet of the Remnant, seeing in this " preparedness " only preparations for a new imprisonment, reminded the governor that they lived " not by might, nor by power, but by My Spirit, saith the Lord of Hosts."

But Zerubbabel and the priests, possessing a Babylonian sense of the fitness of things, aimed at the acquirement of despotic power over the people. Discrimination was made between the Children of the Captivity and the Remnant, who were in process of being naturally welded by intermarriage. The Remnant were now called "adversaries" by the intolerant priestly faction, and when Zechariah protested, he was killed, which caused intense bitterness to spring up, with a tendency to reprisal and counter-reprisal.

The building of the wall was stopped and the gates were burnt by fire.

Armed with the decree of the Persian king, Artaxerxes, Ezra of the Dispersion arrived to assist the hieratic faction. 
He proclaimed throughout the land that all the Children of the Captivity should gather themselves together at Jerusalem within three days, failing which their property would be confiscated, and dissenters would be accounted "strangers."

Shivering in the rain which was falling, the awe-stricken people were told how wicked they had been, and commanded to alienate their "strange" wives, together with the children of the marriages.

This violation of natural affection and humanity, so characteristic of the fanatic in power, resulted in the Jews becoming a Peculiar People or Chosen Race, hated by and hating their "adversaries," whom they stigmatised as "Canaanites, Hittites, Perizzites, Jebusites, Ammonites, Moabites, Egyptians and Amorites"!

Traced to its origin, the economic inequality created by the intrusion of the much-consuming city-dwellers was the first step in the chain of circumstances which produced what would have been a temporary resentment, but which the priests established as a permanent intensified religious hatred.

The aversion and dislike felt by the Jews of the Captivity towards their kinsmen had far-reaching consequences. When Sargon's colonists, the Samaritans, offered, as worshippers of the same God, to assist in the rebuilding of the Temple, the Jews indignantly repulsed them, and an antagonistic egoism was set up in Samaria. This jealous policy was entirely foreign to the spirit of the great prophets of Judah, but it became the obsession of the hierarchy, and resulted in incalculable calamities.

Loathed and detested, the Jews have suffered for their unfortunate narrow and sectarian exclusiveness throughout the ages. In the history of the nations there is probably no more extreme illustration of nationalism. The pogroms in continental Europe of modern times are directly consequent upon the progressive growth of hatred, first crystallised into rigidity by Ezra the Scribe.

In the Book of Leviticus, the hand of the "ready scribe" may be detected by comparing ch. xix ver. 34 , of an earlier period, with the later immoral doctrine of ch. xxv ver. 44, 45 and 46 , in which the Jews are enjoined to enslave the children of the "strangers that do sojourn among you." 
The Jews were now subjected to heavy ecclesiastical government. The tribute to Persia was small in comparison to this taxation, but it was multiplied by the cruel rapacity of the nobles, who even confiscated the tithes intended for the Levite, the fatherless and the widow. The small holders fell into debt, and were imprisoned by that slavery which proceeds from usury. The children of the Chosen People themselves were sold into slavery by their parents.

Nehemiah, the king's cupbearer, was then commissioned to go to Jerusalem with the object of remedying these unfortunate symptoms. The benevolent reformer appears to have considered that the cause lay in the mixed marriages, which still continued in accordance with Nature's contempt for man-made laws, for he vehemently declares, "And I contended with them and reviled them, and smote certain of them, and plucked off their hair!"

Civil commotion, pestilence and famine followed the well-intentioned efforts of the "controller," who vaguely was conscious of failure, for he frequently and pathetically remarks, "Think upon me, my God, for good, according to all I have done for this people."

Ezra and Nehemiah's god was a limited extra-cosmic conception like Ormuzd, the Zoroastrian god of heaven. He was not the Supreme God of the universe put forth by the great prophets. "To do justly" is a universal principle. "The Gentiles," said Isaiah, "shall come to Thy light, and kings to the brightness of Thy rising."

\section{The Maccabees.}

In their veneration of the priest the Jews soon forgot the Deity. Their yoke came not from foreign oppression, but from the hieratic despotism, which became involved in the competitive struggles between Egypt and Syria, under the Hellenic dynasties of the Ptolemies and the Seleucidæ.

The wealth and magnificence of the high-priests, supported by a superstitious laity, led to intrigue, jealousies and hatreds. The priesthood and people divided into factions, one of which adopted Hellenism by contact with the Greek influence and became for a time supreme. A violent persecution of the orthodox Jews was set on foot, a favourite 
test of conformity being the eating of swine's flesh, which excited the revolt of the Maccabees, who headed a struggle for national freedom.

The Maccabees, after a long and fierce war, became more religiously intolerant than ever with each other and with their neighbours. In accordance with the habit of egoisms, they were split into new factions, out of which grew the quarrelling sects of Pharisees and Sadducees.

\section{The Pharisees and Sadducees.}

The cult of Hellenism was probably responsible for the belief of the Pharisees in a future life, in rewards and punishments hereafter, and of Paradise and Hell. Punctilious about forms and ceremonies, they "strained at a gnat and swallowed a camel." "Sitting in Moses' seat, they made the word of God of none effect through their tradition." They were the Liberal Party of the hierarchy.

The Sadducees were the aristocratic, landed class, and they formed the " national " party, simulating great patriotism. Placing culture before justice, they were direct spiritual descendants of Ezra.

\section{The Ruins of Judaism.}

The history of the Asmonæan kingdom under Maccabæan princes and Herod kings is one of continual civil discord and crime. The profiteers obtained such wealth and influence that they controlled even the opinions of the people, whose minds were in a state of utter darkness.

Land was in the hands of the very few, and the dispossessed were not less explosive because they were confined in a smaller space. The people sought any outlet for the relief of pent up feelings, but without any realisation of the fundamental cause of their bondage.

Greater power and frightfulness were necessary to restrain commotions, and the enclosed people advocated and provided the very instruments which made their conditions worse, in the belief that in force alone lay the solution of their miserable tangle.

Atrocities were committed in the strivings of the cliques equal in cruelty to any to be found in the bloodstained pages of the old regal period of Israel. We read of Alexander 
Jannæus, the high-priest and king (B.c. I05-78), after a victory against his own countrymen, executing eight hundred prisoners by crucifixion, while he feasted in view of them as they hung dying, in the presence of his wives and concubines.

Sexual perversion was rife and polygamy flourished. Leprosy and other vile diseases tormented the bodies of rich and poor alike. Lunacy sometimes brought relief to the minds of the mentally defective victims, aberrated by the struggle for existence in a hostile environment.

\section{The New Prophets.}

The wave of hope aroused by the success of the Maccabæan revolt had broken on the rocks of bitter disappointment. The Zealots failed because they attempted to raise themselves by the domination of others. Fighting had not brought freedom, but only increasing hatred and slavery, which cultivated disunion and produced enemies on every side.

There were yet many who thought that freedom could be attained by means of physical and moral violence, and the Jews, after Palestine had become the tributary of Rome, continued to look for a Messiah who should lead them to victory over their enemies.

But a small minority of thoughtful men had learnt a lesson from the recent happenings. They saw that the foreign parasite was in reality supported upon the backs of the home variety, whose power was weakened, if anything, thereby, and that the country had greater freedom under Roman rule than when they lived under the cruel sway of their own princes and the priesthood.

From the fragmentary records of the gospels in the New Testament we glean that the New Prophets taught the people that a change of heart was necessary-that the prevailing point of view was wrong: "Ye must be born again," said they.

\section{The Kingdom of God upon Earth.}

John the Baptist and Jesus of Nazareth put forward the ideal of a spiritual State founded upon justice and loveof a kingdom of God upon earth, as it is in heaven, to which men and women might belong, no matter what their obliga- 
tions to earthly tyrants might be. Jesus told the people that He came not to destroy, but to fulfil the Law and the Prophets; that is, $\mathrm{He}$ came to make men free.

\section{Slavery and the Philosophy of Jesus.}

A war waged by slave-owners in order to impose slavery is manifestly immoral, but it was not so evident that physical and moral violence are vain as means of obtaining freedom from slavery.

Nevertheless, painful experience had testified to these earnest labourers that warfare is a gamble against the bank of Satan, and that the dice are loaded against all the belligerents. It is impossible, by continuing the gamble, to obtain reparation and restitution. "The loser always pays," and in war all the gamesters are losers. The real war-debts are hatreds, the seeds for propagating future wars and further slavery, until civilisation is bankrupt. The gain to those who "cut the loss," is in the lessonlearn or perish. "Put up again thy sword into his place; for all they that take the sword shall perish by the sword."

If the slaves are victorious, slavery is not abolished: the slaves, remaining ignorant, only become slave-owners, and experience teaches that the one-time slaves become severe and cruel taskmasters.

Freedom is only obtained when ignorant ill-will is superseded by enlightened goodwill. Only in this way can the slaves see by which instrument they are enslaved. They will then see that the responsibility is their own, and that freedom may therefore be obtained at will.

The parasitic slave-owner is a more miserable slave than those upon whom he battens. Living in an enervating, luxurious prison, how can he, even less than his servile attendants, understand the delights of freedom? The thought of the plunge into the cool waters of liberty fills his hypercultured soul with dread. The test of John the Baptist in the river Jordan possesses great symbolic meaning.

The Pharisees and Sadducees, men of property, who "devoured" widows' houses and "for a pretence" made long prayers, were thought by the peasants of Galilee to be the salt of the earth. They thought Jesus mad when 
He said, "It is easier for a camel to go through the eye of a needle than for a rich man to enter into the kingdom of God." "Who, then, can be saved?" asked the poor men, in pure bewilderment.

\section{How to Obtain Freedom.}

The door opens inwardly, and it is obstinate vanity attempting to hack a way through, upon the selfjustifying plea that "things cannot be taken lying down." In this mood, when weary, the fighter for freedom is easily captured by a new tyranny. The slave ceases to be a slave when he no longer denies freedom to others. He is a free man when he no longer does to others that which he does not care to have done to himself-when he learns "to do justly and love mercy." "Ye shall know the truth, and the truth shall make ye free."

Mere good-nature is not enough. This is the unprotected condition, which is so easily decomposed by false doctrine into the will to hate. There must be goodwill towards men.

The New Prophets, therefore, sought to remove the scales which obscured the mental vision of the people. They saw that Hatred is the child of Ignorance, and that it grew and fed upon Physical and Moral Violence, which manifested itself in War and Slavery.

\section{The Code of Jesus.}

The Decalogue enjoins, "Thou shalt not kill," but this is extended by Jesus, "He that hateth his brother is a murderer." The righteousness of the scribes and Pharisees was inadequate: "Ye have heard, that it hath been said, 'Thou shalt love thy neighbour, and hate thine enemy,' but I say unto you, 'Love your enemies, bless them that curse you, do good to them that hate you, and pray for them which despitefully use you, and persecute you.'

"Ye have heard that it hath been said, "An eye for an eye, and a tooth for a tooth': but I say unto you, that ye resist not evil; but whosoever shall smite thee on thy right cheek, turn to him the other also." Do not behave cowardly or insolently, but by conviction refuse to be a party to hatred and violence of any kind. 
"Strike, but hear me!" said Themistocles, when threatened violently by an adversary in argument. The principle rests upon the bedrock of the social instinct. It is wise foresight never to be vindictive-reparation comes in unexpected ways. The gain is in the lesson.

\section{The Political Economy of Jesus.}

Was it just, that while the foxes had holes and the birds of the air their nests, the Son of man had not where to lay His head? Yet, since the sun shines upon the evil and the good and the rain falls upon the just and the unjust, everyone had an equal right to life, liberty and the pursuit of happiness. Those who would discriminate for others might find discrimination exercised against themselves. "Judge not, that ye be not judged."

Jesus taught the abandonment of property claims in so far as human need required such abandonment. To the old questions, "What shall we eat, or what shall we drink or wherewithal shall we be clothed?" He answered in these words of deep economic meaning: "Seek ye first the kingdom of God and His righteousness, and all these things shall be added unto you."

When to God, e.g. to the individual, there were rendered the things that were his, and to Cæsar, e.g. the community, the things that belong to all, then from this secure and sound foundation there would be erected by common consent a stable social system, without the necessity of props of power, subject to dry rot and sudden collapse.

\section{The Unchangeability of the Gommandments of God.}

Man, possessing freedom of choice, is a free agent within certain limits, which may be defined, but which may not be overstepped. The "commandments of God" or "laws of Nature" are omnipresent, omniscient, eternal and immutable. The Sage of Galilee insisted that it was futile to attempt to alter "the will of the Father." The Golden Rule, like the Law of Gravitation, is as old as the universe. Man has neither created this planet nor does he rule it, and before he knew anything of the existence of natural laws he unknowingly obeyed them. He obeyed the Law of Gravitation before Newton discovered it, just as he was whirled through 
space while he vehemently protested that the earth stood still. He obeys the Golden Rule also under the stress of necessity, in obedience to the fiat, "This do, or perish."

While man's enactments may be broken, it is vanity to talk of "breaking the commandment of God." Natural law may be disregarded perilously, but one does not break, suspend or alter the Law of Gravitation by jumping from the top of a high cliff. The Golden Rule is not broken when men or nations fight and kill, each deluded into thinking that by the subjugation one of the other peace and happiness can be ensured. The penalty in the consequences is exacted " to the uttermost farthing." "Verily, I say unto you, till heaven and earth pass away, one jot or one tittle shall in no wise pass from the law till all things are accomplished."

The Prince of Peace demonstrated that there was more to unlearn than learn: "Suffer the little children to come unto $\mathrm{Me}$, and forbid them not, for of such is the kingdom of heaven." It was prejudice or lack of imagination in the minds of the grown-ups which barred the way to the establishment of God's kingdom on earth. The jostling, scrambling multitude did not hear the decree of the Inexorable: Children, not this wise: children, not that way!

\section{"As ye Sow, so shall ye also Reap."}

Wrong-headed theories should be tested by the only test available to science: "By their fruits ye shall know them." It is plain common sense that you cannot gather grapes of thorns nor figs of thistles. There is only one answer to the question, "What must I do to be saved ?"

Obey the commandments of God, not in fear of some punishment hereafter, nor with a view to the securing of special favours, but as an inevitable necessity. Those who conform to these principles Jesus likened unto a wise man who built his house upon a rock; while those who disregarded them He likened unto a foolish man who built his house upon sand. He did not call the man who conformed with the law a saint, nor did $\mathrm{He}$ denounce the heedless person as a sinner. In Nature there is neither partiality shown to the one, nor vindictiveness to the other. 
No matter how often or how greatly man may err, he is forgiven so soon as he "repents," that is, so soon as he "learns to seek the kingdom of God and His righteousness."

\section{He was Misunderstood, Despised and Rejected.}

"The common people heard Him gladly," but He was misunderstood by many, who thought these things should come to pass by power and might. On one occasion Jesus escaped into a mountain, perceiving that they were about to "come and take Him by force to make Him king."

But "He stirred up the people" by His teaching, and they began to ask awkward questions. The profiteers knew they must take action. They therefore charged Him with blasphemy, and by means of their agents, the scribes, they aroused the religious prejudices and passions of the sects against Him.

It was not in the interests of the Roman authorities to oppose vigorously the insane wishes of the Jewish mob, the excitement of which had to be discharged. Jesus was handed over to be crucified, suffering the usual death of a slave-malefactor.

The Redeemer was killed not for His theology, but for His politics. After the great Sacrifice, His followers said of Him, "But we hoped it was He which should redeem Israel," meaning a political redemption by force. 



\section{NOT BY POWER, NOR BY MIGHT}

\section{READER'S GUIDE}

Chapter $\mathrm{XI}$ is a sequel to Chapter $\mathrm{X}$, and in it we see how a great philosophy can be obscured and perverted when peoples fall into economic bondage.

\section{The Headings are:}

The Early Christian Communes-Power and Might enter the Churches-The Christians become InsularThe Cœnobites and Anachorets-Power and Might replace the Light of the World-The Tomb of Ritual -The demoralised Laity-The Church Militant-" The New Presbyter was the Old Priest writ large "-The Bankrupt Church-The Hope of True Religion. 
The Land is no man's property; none shall possess it as property.-Tertullian (earliest of Latin Fathers, A.D. I55-222).

No man shall come into our commune who sayeth that the land may be sold. God's footstool is not property.-ST. Cyprian (Latin, 200-58).

How far, O rich, do you extend your senseless avarice? Do you intend to be the sole inhabitants of the earth? Why do you drive out the fellow-sharers of Nature and claim it for yourselves ? The earth was made for all, rich and poor, in common. Why do you claim it as your exclusive right ?-St. Ambrose (Latin, 340-97).

Tell me whence are you rich? From whom have you received? From your grandfather, you say; from your father. Are you able to show, ascending in the order of generations, that that possession is just throughout the whole preceding generations? Its beginning and root grew necessarily out of injustice. Why? Because God did not make this man rich and that man poor from the beginning. Nor, when $\mathrm{He}$ created the world, did $\mathrm{He}$ allot much treasure to one man and forbid another to seek any. He gave the same earth to be cultivated by all. Since, therefore, His bounty is common, how comes it that you have so many fields and your neighbour not even a clod of earth?...

The idea we should have of the rich and covetous-they are truly as robbers, who, standing in the public highway, despoil the passers. -St. John Chrysostom (Greek Church, 347-407).

The gods are dead, but in their name

Humanity is sold to shame,

While (then as now) the tinsel'd priest

Sitteth with robbers at the feast,

Blesses the laden blood-stained board,

Weaves garlands round the butcher's sword,

And poureth freely (now as then)

The sacramental blood of men.

Robert Buchanan: New Rome. 


\section{NOT BY POWER, NOR BY MIGHT}

\section{The Early Christian Communes.}

The early Christians were Communists, "Not one of them said that aught of the things which he possessed was his own." By means of this voluntary co-operation, little knots of brethren all over the world, sharing all things, struggled to realise the law of brotherhood. So long as the numbers in fellowship were small, the churches met with a measure of success, and it is said they were never in want.

It is a melancholy fact, however, that ideals, like persons, are deranged by an environment of social injustice. Before there can be a reign of Benevolence, there must be a reign of Justice.

The ideal of the kingdom of heaven upon earth was no exception to this rule of deterioration. It was in turn obscured, distorted, inverted and finally shattered into fragments, just as a healthy captive, confined in a dungeon, is adversely affected and finally loses his reason.

Free men and women are regulated by the Great Social Law of Equity. The Golden Rule, based upon the social instinct, "Thou shalt love thy neighbour as thyself," is a patriotism unattainable by the slave or slave-owner until his point of view is changed and he is able in imagination to transfer himself into the New World while yet living within the Old.

It is difficult for a man who has had to sell his daughter into slavery, to save the family from starvation, to understand that he should love his neighbour as himself. It is barely reasonable to expect the bitter-minded helot of the soil, condemned like a beast of burden to a hopeless life of hard toil, to "resist not evil." On the other hand, a change of heart in the suspicious despot surrounded by 
secret danger, attended by chicanery and flattery, encouraged in brutish self-indulgence, is even less likely.

The intrusion of those who had not first sought the Higher Truth, and who wished either to find scope for ambition or merely wished to live upon their neighbours, content with low material advantage only, was fatal to the success of the communes. These had not been "born again," and they were not impelled to uphold the Higher Standard of all.

The early Christians had to learn by bitter experience that while numbers increased rapidly, freedom did not increase, but finally disappeared altogether.

\section{Power and Might enter the Churches.}

Critical investigation during recent times has disclosed the fact that, just as the teachings of the Old Prophets were made of none effect through the subsequent veiling over by false doctrines, so also have the teachings of the New Prophets been largely deprived of their value by the superimposed fraudulent doctrines now taught and put forward as Christianity.

To such an extent has this process been carried that professing Christians may criticise, ridicule, condemn and reject the Sermon on the Mount, without incurring any censure, but they may not examine or cast doubts upon what we shall presently see is palpable forgery. There is furthermore not a single doctrine or dogma in this spurious Christianity based on the teachings of Jesus.

One of the first to obscure and distort the genuine teachings of the New Prophets was Paul, upon whose philosophy was built an apocryphal theology, now known as the "Christology of Paul."

This so-called spiritual Christianity cannot be harmonised by any theological casuistry with the "ethics of Jesus." Paul's sensual conception of a kingdom of heaven not on earth, but located somewhere in the sky, where the saints were "to eat and drink at the table of the Lord, and sit on thrones judging the twelve tribes of Israel," is comparable only with the happy hunting-grounds of the Red Indians. "This, then, is the first turning of the road where Christianity has gone wrong and misdirected those who followed 
its lead. It taught that the world was ruled by a moody, capricious tyrant, who is amenable to flattery and bribes, whose will may be subordinated to our own, and on whose changing moods it depended what kind of fruit a tree shall bring forth." (Ignatius Singer. ${ }^{\mathrm{I}}$ )

Power and Might thus entered the Church to maintain and defend a faith which has no basis in reason: "If anyone preach unto you any other gospel than the one which we have preached unto you," said Paul, "THOUGH IT BE AN ANGEL FROM HEAVEN, let him be accursed."

\section{The Christians become Insular.}

The Christians now began to exhibit the same characteristics as the "Peculiar People," the Jews, with whom they were often confounded by the nations of the Roman world. In fear of being accused of impiety, they would not take part in the most innocent diversions of the ancients, such as the humane licence of the Saturnalia, commemorating the primitive equality of mankind.

They incurred, and, it must be confessed, sometimes encouraged, the resentment of their Pagan neighbours for gracelessness. The gloomy early Fathers were convinced that the end of the world was at hand and that they alone would be saved from hell's fires.

While the disciples of Pagan philosophy asserted the rights of intellectual freedom, the Christians exercised strictly the jurisdiction of their laws and magistrates over the minds of the faithful. The ecclesiastical government was supposedly based upon the heavenly model, which bore a remarkable resemblance to that of Imperial Rome. The despotic ideal progressed and increased as the inevitable anarchy developed.

Acts of oppression only added new force to the elastic vigour of the mind, and an age of religious controversy was inaugurated in which heresies and schisms appeared that the bishops and presbyters were helpless to suppress. Ill-temper caused trivialities to assume exaggerated importance in the minds of the disputants, who separated into sects. The fettered congregations were frequently robbed

I See Theocracy of Jesus, published by C. W. Daniel, London; also The Rival Philosophies of Jesus and Paul, by the same writer. Published by Allen \& Unwin, London. 
by dishonest pastors, like Paul of Samosata, Bishop of Antioch, a spiritual despot, who, on a charge of heresy, was removed on appeal to the temporal tyrant of Rome.

But the Christian sects exhausted the tolerance even of the polytheistic heathen, and their reputation was not enhanced by the treacherous acts of the Jews in Egypt, Cyprus and Cyrene. Ugly rumours were spread against the Christians, who were often unjustly accused of impiety and of practising secret illegalities. Persecution descended upon the Church, and the sectaries were for the moment drawn together. In the belief that the end of the world was imminent, the crown of martyrdom, combined with the certainty of eternal reward, became a priceless possession greatly sought after by deranged fanatics.

\section{The Cœnobites and Anachorets.}

Nature makes no allowance for errors committed in ignorance, any more than for deliberate wrongdoing. If it were otherwise, we should never learn, and rational thought would be impossible.

The saying of Jesus, like all His genuine sayings, that a millstone might as well be hung round the neck of anyone who would offend a little child, and the offender cast into the sea, carries a deep biological meaning. The first duty of the species is the care of the young. This duty includes the care not only of our own children, but also the children of our neighbour. All experience goes to show that attempts made on a large or small scale to benefit our own children by hurting our neighbour's end in disaster for all.

We dare not neglect the young, either before or after birth. Disobedience of this primary duty, which is based upon the social instinct, results in extinction, the death of the race. A race of anchorites, therefore, such as Paul conceived to be the perfection of saintliness, is contrary to the teachings of the Founder of Christianity, as it is to the laws of Nature.

Paul's initiation of the monastic habit brought terrible calamities upon those who practised the new form of captivity, as well as upon their co-religionists.

In the belief that mankind was composed of criminals and that God was a tyrant only to be propitiated by life- 
long penance and torture, hermits, monks and nuns rushed into every extreme of madness. Their mental atmosphere became peopled with dæmons, dragons and personified temptations, bearing the names of the gods of antiquity.

Actuated by these hallucinations, they withdrew themselves from the society of their fellows and invented strange devices of physical and mental torture for the mortification of the flesh. They hated themselves intensely, and extended this hatred to all mankind, finding a savage pleasure in the morbid admiration bestowed by superstitious spectators upon their antics. Many became religious maniacs and raving lunatics, objects of disgust to all right-minded men and women.

Athanasius, the great metaphysical obscurantist of the fourth century, introduced into Rome the knowledge and practice of the monastic life, and the fashion of associating pleasure with guilt grew everywhere into a vile culture.

The actions of a monk, his speech, and even his thoughts, were controlled by inflexible rule or by a severe and cruel superior. But the desire for freedom is beyond the control even of those who try to will themselves to submission. It betrays itself in involuntary offences, and these were punished by disgrace or close confinement or by fasts, sometimes supplemented by flogging.

Disciplinary measures, which were increasingly necessary as oppression increased, became more diabolical to meet the inevitable anarchical tendencies. By the time of Charlemagne, the abbots indulged themselves in the mutilation of their monks, occasionally putting out their eyes, or, in extreme cases, walling them up in subterraneous sepulchres.

It was natural that, having applied with apparent success forceful inventions to make themselves good and holy, the orthodox should desire to employ these same engines of ingenuity for the regeneration of the heretics and schismatics who strayed from or rebelled against the authority of the orthodox Church. Opportunity for the gratification of this laudable desire was provided when Christianity became the reigning religion of the Roman Empire. It is scarcely necessary to remind ourselves that, just as the Pagans when orthodox persecuted the Christians, so also when the Protestants established themselves in Rome they perpetuated 
the same methods of power and might against those who differed from them.

This is the characteristic performance of all egoisms.

\section{Power and Might replace the Light of the World.}

The constrained Church was easily and frequently split into contending sects by the irritating difficulties which presented themselves as the Christian mythology evolved itself.

The ingenious attention of the metaphysicians and ready scribes of the first and second centuries after Christ was given to the provision of counter-attractions in the new Christology which would appeal to the respectable worshippers of the favourite heathen deities of the Gentiles, and to the creation of a supernatural origin for the poor Carpenter of Nazareth that would not offend the snobbery of the powerful.

Concessions made to suit differing local conditions caused denominations of Christians to spring up, each advocating some more or less subtle difference in doctrine. Consequently, by the fourth century, ingenuity had to be directed to the diplomatic linking up of Christian interests, and towards attempts made to consolidate these various sects into one Church.

This proved to be a task faced with insurmountable difficulties. There were the Rogations, who intensified the general insularity of the Christians into a peculiar belief in predestination and the limitation of the saints, who were to be saved from the final destruction by fire at the last day. These were awkward to negotiate. Not less fatalistic were the strict Donatist sect, possessing the inflexibility of the Jews. Of them Gibbon says: "The invincible spirit of the sect sometimes preyed upon its own vitals, and the bosom of their schismatical Church was torn by intestine divisions." It was, therefore, not easy even to attract the attention of the Donatists, preoccupied as they were with their own afflictions, which, indeed, they tended to cure themselves by wholesale suicides.

The Novations, the Ebionites, the Sabellians, the Manichæans and their kindred sects all contributed to stimulate the pathetic lament of the venerable Bishop 
Gregory Nazianzen, that the kingdom of heaven was converted by discord into the image of chaos, of a nocturnal tempest and of hell itself.

Diplomatic compromise, even at the hands of so learned and courageous a theologian as Athanasius, had its limitations. The Catholics and Arians found it impossible to reconcile the Homoousion and the Homoiousion, the microscopic difference of which was almost invisible to the nicest theological eye.

Christianity, divorced from the eternal principles laid down by its Founder, was irretrievably corrupted and disrupted in the surrounding medium of growing social injustice. The earlier Christians were conscientious objectors to military service, but as bitterness and hatred grew between the competing sectaries, objections to the taking of human life insensibly vanished. The Pagan historian Ammianus stated as his opinion that the enmity of the Christians towards each other surpassed the fury of savage beasts against man. Alienated from their natural rights on earth, the dispossessed contended for the private ownership of heaven, and Theology was placed before Humanity.

Irritations which appeared the least connected with the subject of dispute were sufficient to kindle the flame of civil discord. The Arian and Catholic factions fought each other with a bitterness rarely exceeded in the history of so-called religious wars. But, as Gibbon shrewdly remarks, "The writer who should impute these tumults solely to a religious principle would betray a very imperfect knowledge of human nature."

\section{The Tomb of Ritual.}

In a desire, more or less conscious, to coalesce the scattered fragments of the Church into one catholic whole, groping for a basis of enduring peace, worship was extended far beyond the Triad or Trinity. The Virgin was substituted for Venus, and a new Olympia was filled with the saints as minor gods. As in ancient Egypt, the lofty ideal of One God was ground into powder. Divinity was supposed to cling even to the relics of the saints, real and imitation, and these were worshipped by the infatuated people.

Churches, cities and provinces had their patron saints, and after the subversion of the Roman Empire in the West, 
when the Bishops of Rome extended their domination over the laity as well as the clergy of the Latin Church, the patron saints fulfilled a function in the coalition for a central tyranny similar to that of the gods of Egypt, of Chaldæa, and of Pagan Rome.

Inversion had been carried to such an extreme that the most superstitious savage entering the Church would not have missed for long his cherished tribal fetish or totem. The Church had fallen into superstition to a greater extent than the Paganism it was fondly believed to have overcome.

\section{The Demoralised Laity.}

Rome continually presented the aspect of war and discord : the churches and palaces were fortified and assaulted by the factions and families. Citizens carried arms, and in the twelfth century St. Bernard, who attempted many reforms, thus described the degenerated people: "Who is ignorant of the vanity and ignorance of the Romans ?a nation nursed in sedition, cruel, intractable, and scorning to obey, unless they are too feeble to resist. When they promise to serve, they aspire to reign ; if they swear allegiance, they watch the opportunity of revolt; yet they vent their discontent in loud clamours if your doors or your councils are shut against them. Dexterous in mischief, they have never learnt the science of doing good. Odious to earth and heaven, impious to God, seditious among themselves, jealous of their neighbours, inhuman to strangers, they love no one, by no one are they beloved; and while they wish to inspire fear, they live in base and continual apprehension. They will not submit; they know not how to govern; faithless to their superiors, intolerable to their equals, ungrateful to their benefactors, and alike impudent in their demands and their refusals. Lofty in promise, poor in execution, adulation and calumny, perfidy and treason, are the familiar arts of their policy."

It is unthinkable that these were inherited characteristics ; that the Romans in the short space of a few centuries, by progression in evolution, had transformed themselves into effeminate and hysterical degenerates; nevertheless, appearances at first sight might lead to such a conclusion. Yet, think; would not the struggles of the English men, women 
and children shut up in the Black Hole of Calcutta have seemed just as reprehensible to a spectator who could not see the dungeon walls which surrounded them? Are we not more reasonable to infer that these were symptoms of captivity in an environment rendered hostile by the growth of social injustice, the cause of which was hidden almost completely from the mental purview of the citizens themselves?

The Decline and Fall of the Roman Empire was not caused by the influence of Paganism or Christianity, nor by the incursions of Goths, Huns, Normans and Turks. The barbarians only plundered a helpless people imprisoned by the consequences of their ignorant non-observance of the Law of Equality in social custom.

\section{The Ghurch Militant.}

In the fourteenth and fifteenth centuries pestilences swept over Europe. The Black Death and Sweating Sickness carried off nearly half the population of Western Europe. The pressure in the overcrowded insanitary cities was relieved, and the country districts, already sparsely populated, were deserted. The supply of labourers was lessened more quickly than the landowning classes could restrict scope for opportunities by throwing land out of use. In spite of legislation instituted by the ruling profiteers to prevent wages rising, the labourers who survived were able to obtain a more equitable proportion of the total wealth produced. The conditions of life for the masses of the people therefore greatly improved, partly owing to the better distribution of wealth, but also owing more especially to the concomitant increased production under impulsion of better rewarded individual effort.

The easing of the effects of economic injustice was soon reflected in the better credence of the people. New advances were made in scientific knowledge, which led to great discoveries. One of these was the discovery of America, which was to eventuate in another spurt of temporary easement in the nineteenth century. With greater scientific enlightenment came also the desire for greater civil and religious liberty.

Reformers arose, who protested against the black superstition of the Church of Rome and tried to remedy abuses. But the armies of the Church defended by violence what 
had been acquired by fraud. All pretence of benevolence was soon brushed aside, and the malevolence of proscriptions, wars, massacres, and the devilries of the Holy Office were revealed in their hideous reality.

Vigorous attempts were made to suppress the Protestants, whose appearance filled with hatred and dread the minds of those who wished to profit by the continued ignorance of the people. Catholic princes openly leagued with the Holy See in the common aim, and many rulers assisted in secret, while making a pretence of being sympathetic to the reformers.

In the effort to support the fabric of superstition which had been erected, hundreds of thousands of unfortunate people were executed in the Netherlands and elsewhere or were killed in battle.

\section{"The New Presbyter was the Old Priest writ large."}

But the real bondage was not that of physical and moral violence, which since the time of the early Fathers had developed gradually to meet and restrain the struggling factions of the centuries. Violence is not destroyed by counter-violence, and the Church cannot be redeemed by vengeful slaughter. The real bondage of superstition can only be removed, has only been removed to the partial extent it has, by the greater diffusion of scientific enlightenment among Catholics and Protestants alike.

Until Christians learn that peace cannot be obtained by war, security by menacing their neighbours, goodwill by hatred and happiness by bringing affliction upon others, then murder, robbery, persecution and misery must continue among them.

Behold a Catholic and a Protestant armed to the teeth, each trying to subjugate the other, so as to be able to secure peace and happiness for himself. Neither of them is bad or wicked, human nature is not at fault : it is ignorance only which makes them act in this way.

In place of enlightened guidance, each of them has received a sword, blessed by his blind spiritual leader. It is that they rely upon.

Bravely, inspired as they believe with a high purpose, each thrusts the cold steel into the other's body, in the 
hope of thus securing peace and goodwill for himself. And lest the combatants might foresee before it was too late the folly of mutually destroying each other, the priest or pastor, as the case might be, has cheaply promised eternal peace and glory hereafter to his protégé and the everlasting torments of hell to his opponent! Here we have an epitome of the quarrels between the sects of the Church.

Historians are reluctantly compelled to admit that Christians, in the course of their intestine dissensions, have inflicted far greater severities upon each other than they have experienced from the zeal of infidels.

\section{The Bankrupt Church.}

The philosophy of Jesus, which was the enduring keystone of Christianity, has been discarded and termed "idealistic nonsense" by so-called Christians. It has been dropped out of its important position, and the fraudulent substitute has not stood the test of time.

Freedom-loving men and women view the fallen ruins with regret, but they have no use for a Church in which justice in the clouds after death only may be preached, and where, instead of a currency based upon the Golden Rule, one of counterfeit charity may be tendered and accepted only.

It is not that there are no real Christians to be found in the Churches, but that anyone in search would not economise time by looking for them there before anywhere else. Dissimilation has overtaken assimilation.

The Christology of Paul is known to be a forgery, definitely, because of its failure in the test. The Church may seek to cover her nakedness by drawing about her the bedraggled rags of insane superstition, but she cannot for shame be other than dumb and helpless. How can she advance peace on earth and goodwill towards men while in "irons" for moral bankruptcy?

\section{The Hope of True Religion.}

But, while deploring the decrepitude of the Church and the futility of attempting to put new wine in old bottles, it is necessary in justice to remember the economic environment which has been instrumental in bringing about her 
discomfiture. Truth still lives, and may be found in an environment in which the shadow is not pursued for the substance.

After a reign of Justice there will be a reign of Benevolence. Then will be revealed to mankind the Kingdom of Heaven upon Earth. The Spiritual Evolution of Man is only possible in Freedom. 


\section{THE SEGRET OF HISTORY}

\section{READER'S GUIDE}

IN Chapter XII the nature of what we understand as freedom is exemplified. The Hellenic civilisation is taken as an example of how deterioration takes place as the community lose themselves in a fog of superstition. Incidentally we see that the orthodox historians have looked upon war and warlike preparations as evidences of progress, whereas these are indications that the advancement of society is being checked owing to the growth of injustice in fundamental social relationships. We say that the Secret of History is Land.

\section{The Headings are:}

No Progress without Freedom-The Secret of HistoryThe Revolutions of Civilisations-The European Civilisation-The Age of Uranus-The History of Greece is the Epitome of that of Europe-Early Land Custom in Europe - How Peers become Tributaries-The Grecian Mythology - How the Lot of the Labourer becomes Harder-The Development of Factions and "Powers"-The Effect of Niggardly Production-The League of StatesImperialism comes before a Fall-The Struggle for Supremacy-Short-lived Empire-The Deceitfulness of Appearances-The Republic of Plato-The Purpose of Slavery-A Practical Demonstration. 
No walls were yet, nor fence, nor moat, nor mound; Nor drum was heard, nor trumpet's angry sound;

Nor swords were forged; but, void of care and crime, The soft creation slept away their time.

The flowers, unseen, in fields and meadows reigned, And western winds immortal spring maintained; From veins of valleys milk and nectar broke, And honey sweating through the pores of oak.

Ovid : Met., Book I (Dryden).

If the Spartans had the advantage, They bit their lips and muttered amongst themselves, "Ah! now, my little Athenian, you shall pay for it." And if the little Athenians got the better, Ever so little (when the Spartans came to treat for peace), They screamed and made an uproar :

"It's all a trick-by Jove! By the holy goddess, We're cheated, we're betrayed! -

No, never trust them!"

Aristophanes: The Peace (Everyman's Library). 


\section{THE SEGRET OF HISTORY}

\section{No Progress without Freedom.}

" Just as in geological speculation great diluvial catastrophes have been eliminated and replaced by the action of existing forces operating during enormous periods of time, so the prehistoric archæologists are increasingly disposed to substitute slow progress in culture for the other theories which cut every knot by theories of conquest and invasion. Civilisation, which we find in Europe at the beginning of the historic period, was gradually evolved during a vast period of time, and was not introduced cataclysmically by the immigration of a new race."

Canon Taylor's conclusion is amply established, but it is necessary to remember that while civilisation is of slow growth upon the whole, there have been periods when progress has been made at a greater rate than at other times, and periods again during which decay has suddenly set in, so that instead of progress retrogression took place.

The progress of civilisation may be likened to the advancement of a yacht under sail, which speeds along in the breeze. The pilot on board, representing society, is an amateur. $\mathrm{He}$ steers the yacht too dangerously near the wind, and brings her to a standstill. In technical parlance, the little vessel is in "irons." If the pilot is slow to learn, he may be driven ashore upon the rocks of anarchy, and may have to refit.

The yachtsman does not retain freedom to progress by giving way to violent panic or by refusing to learn from experience. To preserve himself he must act in accordance with certain immutable principles or so called laws of Nature.

The freely running steam engine, quiet and efficient, provides little scope for unillumined comment, but the 
enlightened mind finds a never-failing source of pleasurable interest in it.

If, however, the engine, having been erected upon a defective foundation which had therefore subsided, was out of alignment and strained, so that owing to friction in the moving parts it was almost "scotched," and steam leaked from every joint, no one but a crazy person would find. satisfaction in the spectacle.

The scientific engineer would not try to remedy matters by pouring sand into the bearings, nor would he add weights to the safety-valve of the boiler for the purpose of increasing steam-pressure to overcome the abnormal resistance. $\mathrm{He}$ would instead lay down a sound foundation, and make adjustments which would have the effect of liberating the mechanism.

What would be thought of a professor or teacher of mechanics if he assessed the power and efficiency of a steam engine according to the loud groans it made, the shrieks of escaping steam, and the heat and smoke of strained bearings ? Yet it is according to a similar assessment that many makers of history books have measured the usefulness of a social system!

History, as ordinarily written, is full of the indelectable scandals and crimes of unromantic royalty. It is rarely that reference is made to principles, but its pages overflow with accounts of the sordid intrigues of the Court supermen and women and the predatory diplomacies of scrambling States, each imbued with a belief that it is making the world safe for itself by making it unsafe for all others.

It would appear as though the pretentious warlords and the preachers of "firm" government had filled their protégés, the professors and lecturers of history, with awestruck admiration. The latter seem to regard the hot vapourings of war and civil commotion, which are not evidences of progress but simply signs that the advancement of society is being checked, as manifestations of creative effort. In reality these activities are the death-struggles of a culture which is being disrupted by the stresses and strains set up owing to the retention of decaying and obsolete social institutions.

No progress is possible without freedom. 


\section{The Secret of History.}

"There is a Secret of History. The mot de l'enigme is Land. The great historians of the rank, for instance, of Mommsen, say the word, but then pass on, as though in haste to leave a dangerous ground. Lesser historians shun the mention of it altogether, or mention it in faltering accents. Time, with its effacement of old meanings, helps this obscurantism, and oblivion falls upon the theme." (Dr. F. W. G. Foat.)

One is tempted to ask if there had been a conspiracy of silence, or if an undertaking had been entered into to treat so fundamental a matter contemptuously, as of little account, and to conceal its importance by discussing instead unreal problems in language that is unintelligible.

When explanation is sought for the sacrifice of the brave soldiers who save the community momentarily from the worst consequences of social folly, or when a reason is asked for the surgings and insurgings of nations, collateral and intermediate causes are put forward, such as man's natural pugnacity, notions of honour, wild aspirations towards political liberty, "human nature being what it is. . . ."!

\section{The Revolutions of Givilisations.}

The Revolutions of Civilisations is the title of a book by Mr. Flinders Petrie, the eminent Egyptologist, in which by means of pictures and diagrams he illustrates in a vivid manner the rises and falls of cultures during the historical period.

Possessing no knowledge of the Secret of History, Mr. Petrie has recourse to the discredited theory that an infusion of fresh barbarous blood by means of invasion is necessary for the purpose of revivifying a decadent civilisation. Mr. Petrie then speculates that, the zenith of progress having passed, decay sets in unless a new infusion of a similar sort is given.

Although appearances at first sight may seem to favour such a view, the facts of history are not in support of this theory.

Habits and customs, which in course of time have been petrified into legalised injustice, have sometimes been disturbed by the beneficial interference of new-comers, which 
suspended or modified the harmful ordinances, and thus afforded a spurt of progress. But a similar effect has been produced by the expulsion of intruders, as when the Egyptians expelled the Hyksos, and this very fact cuts out the theory subscribed to by Mr. Petrie.

The realities of history begin to arrange themselves logically in the mental purview when progress is regarded as a product of association in freedom, and impedance the consequence of parasitic growth within the community.

\section{The European Givilisation.}

Past European civilisations were more heterogeneous than those of the Nile and Mesopotamia, and they have escaped, sometimes narrowly, the development of that extreme despotism which turned men out of rigid moulds like bricks, destroying all individuality. Again the student in his survey of them sees evidences of new attempts made to evolve a "rule of the land" which will ensure freedom of action for the individual, bounded only by the like freedom of others.

Self-interest is the most powerful inducement to progress, and the student learns that in adventitiously affording free and equal opportunity to the play of this motive, men cooperate voluntarily to their mutual advantage and achieve real progress in civilisation. On the other hand, he discovers that in seeking to restrain forcibly the freedom of individuals composing them, communities bring about dissociation in which all progress comes to an end and in which retrogression may take place.

$\mathrm{He}$ is confirmed in the belief that any economic or mechanical device of oppression sets up an intolerable strain in human affairs, and that war and civil commotion are thereby rendered inevitable.

\section{The Age of Uranus.}

Private ownership of the person developed in pastoral times, and it existed in Europe as a variable quantity when men began to till the soil. Excepting where war had become a slave-raiding and plundering business, the slavery was mild, and often amounted to wardship in trust to the patriarchal leader. 
Life at the beginning of the Heroic Age of the Hellenes is marked by simplicity and cheerfulness of manners. Music, including games, dances, poetry and the drama, was part of the daily life of the people. There was no poverty, although methods of tillage must have been primitive. Intemperance and disease were rare or unknown, and the early Grecian ideal, which persisted long, was great physical and mental beauty.

There was none of that mutilation of the person, either in bravado or for punishment, which distinguishes tribes that have carried slavery of the person to an extreme length.

It was at a much later period that the Spartan descendants of Dorian invaders offered boys as human sacrifices to the goddess Artemis, of icy and exaggerated virginity.

The priest-kings, gentry or nobles were proud of their manual skill. The hero Ulysses, who boasted of his agricultural knowledge, made his own household furniture. Their wives and daughters assisted the slaves in household duties, fetching water from the well and washing garments in the river. These women, of whose charm poets have sung and whose beauty artists have striven to render immortal, were skilled in household refinements, which flourish best in an environment of happiness. They excelled in weaving, spinning and embroidery.

Polygamy, always a sign of debased custom associated with personal captivity, was not practised at the dawn of Grecian history. The status of the woman was high, as in the earliest period of Egyptian history.

At the time of which we write, fighting was confined to the nobles and gentry, the supporters or clients being interested spectators only. In later times, when retainers took part, a single hero might put hundreds of the combatants, probably possessing no weapons to speak of, to flight. There was no serious bloodshed, and battles were like Irish fairs.

\section{The History of Greece is the Epitome of that of Europe.}

The history of ancient Hellas and the adjoining coasts is an epitome of what subsequently took place in Europe as a whole. Possessing the same religious beliefs and a language much the same everywhere, healthy co-operative emulation between different localities was gradually transformed and 
intensified until small States of about the size of English counties were fighting a life-and-death struggle with each other for dominion.

From time to time competing States joined issue against a similar league, and when opposing leagues exhausted themselves in bitter strife, a third entered, which took advantage of their plight and took revenge for some past depredation. Even when all the States were the slaves of some league, there was no durable peace. To avoid civil and factional outbreaks, recourse had to be made to imperialistic conquest for the purpose of taking attention away from domestic affairs. These ambitions invariably ended in disappointment.

\section{Early Land Gustom in Europe.}

It is probable that the oldest land system in Europe was the allodial sharing of pasture commons with the use for a portion of the year of strips of arable land for each tribesman. This system of land tenure did not permit of great agricultural progress, because individual enterprise was discouraged by the yearly disturbance caused by casting lots and a redistribution, but the system possessed rude virtue, and persisted for a very long period, existing as communal tenure within the feudal system, which came later.

The Aryan tribes, settled on the northern shores of the Mediterranean, possibly as a result of contact with the older civilisations of Troy, Mycenæ and Egypt, evolved a tribal custom in land, similar to the feudal system in its infancy. It was the kind of cross one might expect in the principle of fixed tenure wedded to the allodial system, in which there is no private property in natural resources. This transitional system, until corrupted by the superstition that land can be bought and sold, has everywhere and at all times produced remarkable results in the progress of those living within it. Its advantages may even be seen at the present day among the Kaffirs and the natives of Northern Nigeria, where it is slowly being deteriorated, owing to the influence of European corruption.

The land was held in trust by the priest-king, or tribal leader, and freemen, by paying homage to him as representa- 
tive of the clan, were apportioned holdings, which they could not buy or sell, but which reverted to the trust in the event of death or upon leaving the neighbourhood. The tribesmen were given self-determination with regard to methods of cultivation, and retained the products of their labour, free to keep, to give away, and to exchange with others for services and kind.

Tribes combining pastoral pursuits on commons with agriculture allodially were far in advance of the wandering pastoral nomads, but the Hellenes, by means of the new land settlement, made advancement in civilisation which outranged either. It was not that they were in any way a "wonderful people" or inherently superior to their neighbours, only that the partial temporary economic freedom enabled them to apply their intelligence to better advantage, in other words, to become more scientific.

\section{How Peers become Tributaries.}

Presents in direct labour and kind to the chief were probably made voluntarily at the start, and the leader would feel he should make return in some way to his clan or clients, who would feast with him, and enjoy in equality his hospitality and counsel. Around him would centre the social life, in which the women and children would occupy a large part, and neighbouring clans, or phratrice, into which the tribes were divided, would and did co-operate for larger functions.

It is easy to imagine why the philosophers and poets of later days looked back with regret to this simple and happy period, which they called the Aristocratic or Golden Age.

It would seem natural for the holder of a piece of ground in a better position to be more munificent than a freeman holding a less advantageous site in point of fertility and other features, but there would be no standard measure of contribution. All men were not freemen, and the chief "controlled" the disposition of the lands at whim. The slaves were well treated, and frequently given their freedom as a reward for loyalty, but the mild slavery had its due effect upon the developing institutions. The law of rent would be obscured, because, apart from the communal value of a holding, the number of slaves a freeman possessed 
would affect the determination of his contribution to the noble, who occupied the position of trustee for his peers.

The absence of any just measure, and the fact that favouritism and bribery would therefore have room to develop, would lead to a desire for some compulsory form of assessment. In ignorance of a better way, the contributions, as in ancient Egypt, were made upon the basis of " ability to pay." There was thus no natural limit to the proportion to be contributed by the landholder, nor a corresponding limit to the proportion to be returned to the phratry by the chief. The tithe was simply an income tax or tax upon production, and the gentry, actuated by self-interest unregulated, made it as high as possible.

We do not doubt that the freemen, also actuated by selfinterest, resisted imposition as well as they could; but so long as there is no competitive or economic limitation, users of land are at the mercy of arbitary " controllers," who, from being public servants, by the growth of corruption from lack of automatic regulation, inevitably become public masters. The rate of tribute was increased as the mania of owing things took possession of the gentry, and the spirit of unrest and discontent entered into ancient Hellas.

It is at this stage that a change takes place in the function of leadership. The leader of the community must undertake the stern duty of repressing the growing turbulence of the citizens of the little State, and he can no longer himself remain chief-priest, and possibly principal poet and oracle or councillor. There is an inevitable differentiation, and the spirited ruler makes his appearance, accompanied by persons fulfilling these functions in an especial way. This polity was called by Socrates, in Plato's Republic, the timocracy or timarchy, the government of honour, in which duels take place and the beginnings of warfare.

\section{The Grecian Mythology.}

Not seeing the relationship between cause and effect in the unpleasant developments, it was natural for wisdom to be depraved by vanity into cunning. Enclosure in economic slavery had its usual baneful influence upon the Grecian religion, decomposing it into superstition. There is a great temptation to distort the truth, when that is 
effective for a while in stilling unrest. Some justification had to be invented to account for the growing number of atrocities now taking place. Wrapped up in the Grecian mythology there is preserved a distorted reflection of the early history of Hellas.

While the Egyptian and Chaldæan metaphysical speculations were founded upon a geometrical basis-the triune measure of the universe-the Grecian system was founded upon a biological plan of progressive growth.

In pastoral ages fetishes, such as sacred trees, belemnites, or meteoric stones were objects of superstitious regard. Uranus in the oldest literature of the Greeks designated only the physical vault of heaven, and there is reason for thinking that in emancipating themselves from the earlier Aryan superstitions, and prior to the appearance of the new landslavery, the Hellenes were in process of forming a reasonable credence in the oneness of Nature.

About the time of Hesiod, Uranus was personified, and became the spouse of Gæa, representing earth. It was a logical consequence that they had children, and of these Cronus, god of time, and his sister Rhea, goddess of the earth, were married. Of their children, Zeus and Hera became supreme rulers of Olympia, the older deities being relegated to inferior positions as decrepit generations.

The system was still further extended as the dispossessed younger children of each generation of deities had irregular unions and issue with the children of men, and even with animals. The aberrated superorganic environment of the ancients became crowded with gods, goddesses, titans, cyclopes, gigantes, furies, demigods, heroes, geniuses, nymphs, phantoms and monsters, in all totalling about thirty thousand.

These divinities were believed to take part in the affairs of men, and at the same time to engage in struggles for supremacy among themselves. Their absurd behaviour and childish antics, preserved in the ancient poems and legends, are remarkable examples of oblique imagination, and give a kaleidoscopic reflex of what took place among the blindfolded Hellenes in their struggles for freedom.

Among the Dorians, the timocracy quickly developed into an oligarchy, only those possessing property having political power, and it is interesting to note that the Dorian 
States were the last to adopt a more democratic constitution. In Laconia the inward divisions were smothered by militarism, and every attempt was made to save the citizens from the anarchy prevailing in the surrounding States by means of a rigorous system of schooling and discipline.

Having quenched for a while internal dissension, the Dorians proceeded to prey upon their neighbours. The Spartans, who were descended from the Dorians, carried predatory methods yet further, and their success led them to believe that it was more honourable to steal and plunder from neighbours than to work themselves and exchange fairly. In Sparta it was thought no crime to rob, but it was considered disgraceful to be caught doing so.

The characters of the patron deities accorded well with the changing credence of the devotees. Apollo, the patron of the Dorians, associated with the muses and representing the arts and sciences, was gradually transformed after the Heroic period from this benevolent conception into a cruel, jealous and suspicious deity.

The goddess, Artemis, of chastity and hunting, sister of Apollo and adopted by the Spartans as their patron, changed from an accredited character of healthy and virile maidenhood into a vampire thirsting for male blood. Upon her altar boys were offered as human sacrifices or flogged until the blood flowed. The Spartan mother took a gloomy pleasure in the repression of natural feelings and the obliteration of all human affection. Everything was subordinated to the supposed welfare of the State. With every neighbour hostile, the hardy Spartan spent most of his time in "preparedness," and despised learning as unworthy of a warrior.

In the states of Attica there was a temporary escape from the economic pressure of necessity in the rapid development of shipping and commerce overseas. This leakage in the enclosure bewildered the oligarchical rulers, and the application of the written code of Draco resulted in civil commotion, which was soon beyond their power to suppress. The labours of Solon, and later of Clisthenes, bore fruit in the institution and the transient quietude of a pseudodemocracy.

Political liberty set free a wave of progressive thought, which transformed the accredited character of the patron 
goddess Athena. She was believed to have issued from the head of Zeus with a great war-shout, clad completely in armour and supplied with a sword. This goddess, formerly so warlike, afterwards became so changed in attributes that she was adopted as the patron of all the peaceful arts and trades. As the protectress of women, she was supposed to confer upon them skill in spinning and weaving.

\section{How the Lot of the Labourer becomes Harder.}

The freemen were easily persuaded that the increasing rate of taxation was required in order to uphold the honour of the gods, and the nobles and priests especially attached to the worship of a particular deity strove to direct the oblations of the people seeking for divine favours to the glory of their patron, and incidentally to the aggrandisement of themselves. So long as it was remembered that the property of the gods was in trust for the people, the gentry were self-denying and did not consume luxuriously.

It is a matter of common observation, however, that the memory of the multitude, which "pulls wool over its eyes," soon fails. The zealous trustees awaited with patience the time when they could assume possession and afterwards ownership of the public revenue, to dispose of it as they willed.

The Hellenes were not dumb driven cattle, and discontent frequently broke out into rebellion, but not seeing the light, the blindfolded mobs only struggled with and fought each other, ever losing more and more liberty as they drew the toils in upon themselves. Armed force to keep themselves in order was increased after each outbreak, for the support of which more taxation had to be imposed. The burdens increased at a rapid rate, because the ranks of the producers of wealth were depleted to fill the ranks of the custodians and soothsayers. The latter were nonproducers, but they were heavy consumers.

The free labourers or thetes for a time put forth increased effort, hoping thereby to keep up their standard of living. Unaware that the presence of pressed labour operated disadvantageously in the long run for all men, the thetes exhibited little sympathy for the helots or serfs, who, in proportion as they were driven by hard masters, became 
more efficient. Half a man's worth, said Homer, is taken away on the day he becomes a slave.

The land fell increasingly out of cultivation, and the necessities of life became scarcer in spite of " mass production" and longer hours. The cost of living therefore advanced, and the free labourers, along with freemen possessing portions of land, suffered with the helots. Any benefit the freemen received from increased exertion was only temporary in effect.

But while the plight of the "working classes" became worse, the nobles, skilled in violence, and the soothsayers, excelling in cunning, became rich and powerful. The competition for their privileged places grew keen and furious. It was no wonder that the " art " of war and the " science" of metaphysics developed at a greater rate than the sciences of production and exchange-that, blinded by appearances, the dazzled mob thought it more honourable to kill and plunder than to cultivate and trade fairly.

Along with disappointment and discontent, disease and crime became prevalent.

\section{The Development of Factions and "Powers."}

In each gens the heads of families struggled for supremacy, and the nobles fought for place in the phratry, while the successful hero became king of the tribe. The prizes having been won by violence and cunning within the State, it was "thinking imperially" to extend the process: "War," says Clausewitz, " is only an extension of policy" !

The Hellenes, ignorant of the true cause of social evils, attributed them to the capricious actions of the gods and other supernatural beings, or in default blamed each other. Failing an outlet for their feelings of hatred within the family, gens, phratry or tribe, the emotion was directed against other tribes as the cause, or at any rate as the means of easing their own burden. Any small incitement was enough to start off hostilities. Thus it fell that to subjugate neighbouring tribes, making them also pay tribute to the greater honour of the patron deity or the tribal oracle, was a sacred duty. Tribes were thus welded into States under central masters, as, for example, kings, ephors or oligarchies. 
But the hostility of families and factions was not thereby abated, nor were factions confined within tribal or other limits. In Attica the factions of the Mountain, the Plain and the Shore disturbed the public peace, while the city of Athens was crowded with slaves and impoverished freemen in a perpetual state of party tumult. Discouraged freemen fell into debt, borrowing from the nobles at heavy interest upon the security of their land and persons. Land therefore got into fewer and fewer hands, freemen and their children were frequently sold as slaves to barbarian masters, life and property were insecure, and each egoism tried to repair its own estate at the expense of every other.

\section{The Effect of Niggardly Production.}

If at a daily feast of ten persons there is invariably enough for eleven, an association springs up in which the exchange of the good things upon the table is seen to be beneficial to all. Consequently there is no selfish monopoly: all assist each other, men are chivalrous to women, and the children have their due share and attention.

But if day by day the provisions, for some reason undiscerned, are diminished, these good relations tend to disappear, and when there is only enough for nine people, mothers stint themselves for their children, while persons with little self-control selfishly attempt to monopolise the necessities of life. The exchange of things upon the table in these circumstances is regarded with suspicion.

The supply continuing to fall off, there inevitably comes a time when there is, say, only enough food prepared for five or six hungry people. Even the children are neglected at length, and men, ceasing to be considerate to their weaker companions, fight each other for the acquisition of power, scattering and wasting the food in their battles.

Under the rule of a tyrant, rationing for a while may palliate such a condition of affairs, but this is no permanent remedy. Poverty continuing to creep in upon them, necessity cannot longer be contained, and harmonious relations break down before commotion. The last survival of association is that honourably preserved between thieves robbing in concert. 
Here we have a fair picture illustrating what took place as economic conditions became gradually worse for the Grecian States, due to the land, the source of wealth, becoming monopolised by the few. Land everywhere fell out of cultivation in proportion as the labourer was robbed of the fruits of his labour.

\section{The League of States.}

The process of alienation was accelerated as each tribe went to war, seeking to dominate the other. Free husbandmen of conquered territory were frequently converted into inefficient landless helots upon their own holdings, and victors returning home often found themselves heavily mortgaged and their fields neglected.

To escape from a life which got harder, many wealthproducers, characteristically called " redundant population" by the history books, migrated to the independent cities as artisans, shipwrights and sailors, where they flooded the labour market. This had the effect of depressing the wages of all hired men, and it further caused wealth-distribution to grow more uneven. The merchant princes became very rich and powerful, and the thetes were only free in name.

The unrequited freemen then sought new homes amid freer surroundings in Africa, Italy, Sicily and Spain, where they founded colonies. But since the colonists did not leave behind the system of tribute to the State based upon " ability to pay," they duly produced for themselves conditions similar to those obtaining in the mother States. The trading monopolists handed down their taxes in higher prices upon the consumers.

Commercial jealousies then sprang up between the colonies and the mother cities. Enraged by poverty and unemployment, the cause of which was hidden from them, each independent State failed to see that the competition to serve consumers everywhere by exchange was really co-operation, and that trading was carried on between ports because it was mutually advantageous.

Attempts were continually being made by Corinth, Athens, and Ægina to establish monopolies. It was imagined by each egoism that in some mysterious way it could secure freedom and prosperity for itself by destroying competitors 
who were also customers. The oldest naval battle recorded in Grecian history was fought between the trading fleets of the island Corcyra and the mother city of Corinth (B.c. 664).

Just as the hostile political parties were coalitions of democratic and aristocratic elements, so " balances of power" were formed of the jealous cities and States of ancient Hellas. A Lacedæmonian group, with Sparta as a nucleus, supported by the naval might of the Æginetans, opposed one centred round Attica, supported by the Athenian fleet. Slim States like Thebes remained outside the leagues, watching for opportunities to prey upon necessity. But open hostilities were delayed by the invasion of Greece by Persia, in revenge for the depredations of Athenians and Asiatic Greeks in Asia Minor.

The opposing leagues combined to repel the invaders, but as evidence of the temporary nature of the bond, sedition broke out soon after the battle of Marathon between Athens and Ægina, the rivals only reconciling their differences when Greece was invaded again by the Persians under Xerxes. The most remarkable fact with regard to the invasion was that although the Persians took Athens and occupied the country, they were quite unable to enslave the Athenians, whose freer institutions were beyond their understanding. Failing to discover any channel in the decentralised democracy by which to exploit the population, they were forced to return whence they came. Demoralised by famine and pestilence, they left an army of occupation, reinforced by Grecian allies, mainly Thebans, but it was defeated with tremendous slaughter by one-third the number of Hellenes.

After the expulsion of the Persians, a great league of States, combining the Spartan and Athenian groups, was formed, called the "Confederacy of Delos," in which each State was assessed, and compelled to pay a tribute in money or ships. Intended by Aristides as a protection against foreign attack, the confederacy was employed by the militarists as a powerful instrument to enslave the States. When tributaries revolted, they were subjugated by the remainder, disarmed, and made passive slaves of the central power situated in Athens. 


\section{Imperialism comes before a Fall.}

Following the pirate and the freebooter's maxim, "Let him keep who hath the power, and let him take who can," powerful Athenians in the Government allotted to themselves lands in the islands and territories enjoying the "protection" of Athens. This does not, of course, mean that the magnates intended to till or to use the land themselves. It meant that they had discovered a means of extorting tribute from the citizens of the lands as rent.

For such brigandage Themistocles, who had been foremost in Athenian " preparedness," was banished by the electorate, who afterwards discovered that he had been carrying on a treasonable correspondence with the Persians.

After the death of Aristides, the subjugation of revolted tributaries led to further scandals on the part of magistrates, to so great an extent that it was found impossible, in the then knowledge of political economy, to deal with the offenders. Moreover, these absentee landlords of the islands, living in Athens and suffering much abuse from the envious Spartans, were idolised by the ignorant Athenian mob. The latter were dazzled by the magnificence of successful robbery, and were easily deluded into the belief that in some way they also benefited. A rude shock awaited them.

The hatred and malice of the Lacedæmonians were not lessened because they had their own difficulties. Their oppressed helots were in a continual state of disaffection, and they were offended because of the seeming prosperity of their rivals. The Athenians, on their part, had not forgiven the Spartans for their abrupt dismissal when they went to assist the latter in subduing the rebellious helots.

Against the great league of States there were fast building up feelings of hostility among the Lacedæmonian or Peloponnesian group. It only required a spark to light the combustible material composing the Confederacy of Delos, which had its headquarters at Athens.

Imperialism may be likened to the quarrelsome busybody who, leaving her own ill-managed and disorderly hearth, proceeds, highly motived by feelings of false virtue, to show her neighbours across the way how to settle their differences. The interference of the Athenians in the quarrel between Corinth and its colonists of the island of 
Corcyra was the irritating incident which started the long Peloponnesian wars.

\section{The Struggle for Supremacy.}

It is not remarkable, knowing the hidden fundamental cause of the strife, that the struggle lasted off and on for twenty-seven years without satisfaction for either side. The material strength of the opposing forces was fairly well-balanced, and neither side possessed any advantage in a moral count. Each sought only to dominate the other for parasitical reasons.

Sometimes Sparta predominated, and at other times the Athenians got the better. When in an exhausted condition a truce was declared, a consuming desire for revenge soon brought it to an end. The belligerents were struggling within a vicious circle of superstition, unable to see that fighting was moral cowardice and only made matters worse.

The rulers of Athens relied upon imports of food by sea, which supply proved insufficient for the needs of the citizens, swelled in numbers as they were by the addition of the country people of Attica. The walled city was found to be a death-trap instead of a refuge.

Reduced by famine and captivity, the incarcerated population fell easy victims to a plague or gaol fever, which especially attacked their mental faculties and for which the physicians had no remedy. Instead of attributing the calamity to imprisonment, the Athenians blamed everything else. Some said it came from the wells, believed to have been poisoned by the Peloponnesians, others that it was communicated by infection from Africa and Asia, where other overcrowded plague spots were known to exist, while many said that the blight was due to the anger of Apollo, the patron god of their rivals.

Insanity and death followed upon the despondency of the afflicted prisoners, and survivors in despair abandoned themselves to all manner of excess, debauchery and crime. The numbers carried off by the pestilence far exceeded those slain in battle. It was estimated that not less than onefourth of the whole population died from disease.

Exasperated by misfortune, the Athenians vented their feelings of dissatisfaction upon their leaders. The enraged 
multitude, deaf to reason, could only hear the demagogue who was most capable of interpreting to them their frenzied imaginings. Pericles' moderation and zeal were outshone by the blatant leather-seller Cleon, who appealed to the worst passions of the mob, while Alcibiades was a fitting leader for the privileged classes.

As the war advanced hatred burnt ever fiercer. All feelings of humanity were sacrificed to ruthlessness and frightfulness. In her fearful extremity Athens visited with greater violence any State which revolted from the alliance or which wished to remain neutral than she did the Lacedæmonians, and the latter, as a reprisal, had no mercy upon the survivors of any Ionian city falling into their hands.

In Corcyra the democratic party sided with Athens and the aristocratic party with Sparta. A life-and-death struggle took place, in which the most sacred sanctuary afforded no protection and the nearest ties of blood and kindred were sacrificed to civil hatred. In one case a father even slew his own son.

After the shameful violation of the Peace of Nicias, when an island or city was taken by siege or blockade, it frequently happened that the males were mercilessly slain in cold blood, while the women and children were sold into slavery to purchase provisions for the Athenian fleet or the starving city.

Such a war could not end by agreement to live and let live. The complete subjugation of one side by the other and a certainty of future violence was the only termination possible. In the end the Spartans gained the Dead Sea fruit of victory.

\section{Short-lived Empire.}

After the fall of Athens the unstable rule of the Thirty Tyrants was established by the Spartan Lysander following a reign of terror. Other cities were controlled by oppressive governors, who possessed almost absolute power. Many thousands of Greeks, with skill only in the art of war, sought employment with the Persians, who had assisted the Lacedæmonians against the Athenians, and they were joined by many more who tired of the Spartan tyranny. The 
main result of the never-ending wars was the deepening enslavement of the commoners.

The ascendancy of the Spartans only lasted thirty years, and we do not propose to weary ourselves, because the purpose has been served, by recalling in detail how the Thebans entered in upon the scene and made an alliance with their ancient enemies the Athenians, becoming supreme masters of the Hellenes, and retaining their position even when the fickle Athenians supported the Spartans. Nor how Greece, prostrated by dissensions, became the slave of Philip of Macedon, whose son Alexander the "Great" conquered Persia and Egypt and invaded India.

\section{The Deceitfulness of Appearances.}

The Athens of Pericles in 448 B.c. was at the height of her glory, but the hectic flush of seeming prosperity, that enraptures the superficial historian, was not of health, but of approaching dissolution.

The democracy, wonderful achievement though it was, was not founded upon justice, the nature of which was hidden from the Hellenes. Did not the personification of Dice or Justice, who was armed with a sword, lose her sight ? It was fitting that in such a State licence should be confounded with liberty and insolence with equality; that men should ruminate unsteadily, "Shall I by justice or by crooked wiles climb to a loftier stronghold, and, having thus fenced myself about, live my life ?"

Equal political rights, such as they were, could not take the place of equal opportunity to the resources of Nature. Coexisting with the increasing tendency to unequal wealth-distribution and the attendant niggardly production, equal political rights were doomed to result in anarchy and despotism.

That the Hellenes, and especially the Athenians, became vain, ferocious and fickle, was not due to some imperfection inherent in their nature; it was simply because their minds were deranged gradually in consequence of captivity due to non-observance of the Golden Rule in social institutions. They did not see where they had gone astray, but fancied, among other things, that their misfortunes were due to the caprice of the gods. 
Consequently, they believed that the gods might be turned from their purpose by the supplications of men. Said their greatest poet :-

Yea, even the gods do yield to entreaty;

Therefore to them men offer both victims and meek supplications, Incense and melting fat, and turn them from anger to mercy, Sending up sorrowful prayers when trespass and sin is committed.

Iliad, ix. 497.

Like the priesthood of the present day, the soothsayers of ancient Greece persuaded men that they could be absolved and purified from crimes, both while they were still alive and even after death, by means of certain sacrifices and pleasurable amusements called Mysteries, which delivered mortals from the torments of the other world, while neglect of them incurred the punishment of an awful doom.

Socrates taught that it was impossible to escape from the consequences of our acts, that "Injustice breeds divisions and animosities and broils between man and man, while justice creates unanimity and friendship." He held that a just man would not deal unjustly with a man who is not just; that the virtuous man would continue to act justly though others thought him a fool or a knave; that to put a just man to death for his integrity could only have evil consequences for his murderers.

The prophet of Athens considered that he had a divine mission to show men of all classes that they were profoundly ignorant that they were ignorant. $\mathrm{He}$ confounded their loose reasoning, because the words justice, freedom and piety, and the like, had no definite meaning in their minds. "To use words wrongly and indefinitely is not merely an error in itself; it also creates an evil in the soul." (Phado.)

He saw that so long as his countrymen believed all the horrible and immoral stories of the gods told by ancient writers like Homer and Hesiod, and imitated by the later poets, they would never understand the Higher Truth, that human vice, disease and misery could be replaced at will by virtue, health and happiness. It was impossible to accept a credence in freedom of choice if the gods were supposed to intervene in the interaction of cause and effect. 


\section{THE SECRET OF HISTORY}

For this teaching Socrates was called an atheist, a quibbler; and ridiculed for "making the worse appear the better reason." He was deemed an incorrigible nuisance, because in the search for truth he demonstrated, out of their own mouths, that those whose reputation for wisdom was highest in the State were generally in a condition of that " shameful ignorance which consists in thinking that we know what we do not know."

The profiteers in injustice and falsehood were offended when they found that the youth of Athens were listening to Socrates' teaching ; they felt instinctively that their power would be gone when the eyes of the citizens were opened. Socrates was therefore brought to trial and accused of impiety to the gods and of corrupting the youth of the city.

It is significant that the indictment preferred by Meletus, the obscure young poet, was backed by Anytus the artisan, and the real mover in the matter. Anytus had suffered for his zeal in the cause of the democracy at the time of the oligarchy of the Thirty. He represented the superstitious mob of Athens, and it is not improbable he believed that Socrates, who did not dissemble his views of what is at the present day carelessly labelled "Socialism," was a dangerous reactionary.

Socrates was found guilty by a small majority and condemned to death.

\section{The Republic of Plato.}

In a world which accepted slavery as a divine institution, Aristotle, in the interests of the slave-owners, pleaded for a " national minimum," on the grounds that while a slave might be insolent, fed and kept idle, he could not possibly work if inadequately nourished. So influenced was Plato by the confused multitude and mixture of ideas surrounding him from childhood, that in spite of his association with his master, Socrates, he was unable in his Republic to imagine a State in which there were no slaves.

In the ready-made Platonic conception of an ideal State, every natural desire and affection was to be violated: men and women were to be regimented in camps and controlled by philosophic supermen, similar to our Fabian "Aristocracy of Intellect." All love-matches were to be forbidden. 
Women were to be the common property of the State, and children were to be bred like prize cattle in a stud farm.

As fast as the children were born they were to be received by State officials, whose especial care would be the regulation of the population in quality and quantity. "And will not these same officers have to superintend the rearing of the children, bringing the mothers to the nursery when their breasts are full, but taking every precaution that no mother shall know her own child, and providing other women that have milk, if the mothers have not enough; and must they not take care to limit the time during which the mothers are to suckle the children, committing the task of sitting up at night, and the other troubles incident to infancy, to nurses and attendants?" (The Republic of Plato, p. I68.)

The natural right of the parent to his or her own particular child was not to be respected. The discriminating instinct of maternity was due to prejudice, therefore its satisfaction must be forbidden! The word "forbidden" is frequently used in this portion of the Republic. No tyranny outranges that of benevolence in refined cruelty!

It is safe to say that no one would have been more astonished than Socrates himself to find that he was the accredited father of such a monstrous conception. Socrates, whose God "is one and true in word and deed: He neither changes Himself nor deceives others," considered that it were better to die than knowingly to utter a falsehood. In Plato's servile State, justice and freedom are conspicuous by their absence, and mendacity is therefore regarded as a necessity. "It is probable that our rulers will be compelled to have recourse to a good deal of falsehood and deceit for the benefit of their subjects." (P. I67.)

Socrates was not made to drink the hemlock for adherence to this disastrous doctrine.

The academic attempt of Plato to define an ideal State in terms of schoolmasterlike governors and subservient grown-up schoolchildren was a dangerous proceeding, and illustrates how, possessed of credible guidance, one may easily lose oneself in the surrounding fog of superstition. The aristocratic State, in so far as the real Socrates could have defined it, was presumably one in which free men and women were peers led by naturally chosen leaders, not 
degraded slaves driven by an artificial caste of guardian slave-owners.

With self-determination for every individual reaching manhood and womanhood, the real democracy is the genuine aristocracy.

\section{The Purpose of Slavery.}

The passing epoch of accidental parasitism is not without purpose, for there is nothing purposeless in Nature. Just as in the individual to experience pain may awaken a dormant intelligence, so the terrible consequences of slavery of every kind serve to arouse a new consciousness socially of our duty towards our fellows.

It is symptomatic, at the turn from flood to ebb of a civilisation, for some few vigorous minds to put forth exceptional efforts for a spiritual awakening, and the number of these appears to increase in each succeeding crisis. Shining like great lights against a gloomy background, the deeds and thoughts of enlightened souls appear almost superhuman by contrast.

The dazzled doctrinaires with weak vision fail to note that slavery is the cause of retrogression in an experimental culture, and are deluded into thinking that slavery is a means of progress. These false prophets preach a " new slavery for the elevation of the type man" with the same zeal, and for the same psychological reason, that the drunkard preaches the efficacy of alcohol and dope.

Slavery is not a means of progress, any more than poison is a means of life; but just as the condign consequences of the taking of poison act as a deterrent teaching the wise that it is the will unto death, so the consequences of slavery act as a fearful warning, signifying that progress is not possible in that direction.

\section{A Practical Demonstration.}

Sparta, a hundred and sixty years after the Peloponnesian wars, gave a positive object-lesson of the immediate benefits accruing even from a partial reform based upon justice.

The number of freemen had been reduced to seven hundred, and land was in the hands of the few, conse- 
quently wealth was concentrated among a few monopolists. The primitive simplicity of Spartan manners had given place to luxury on the one hand and abject poverty on the other.

The young king Agis attempted to revive the ancient Spartan virtue by cancelling all debts and by making a new distribution of lands, piously claiming support in the traditions attributed to the national lawgiver Lycurgus. The king relinquished all his own property, as well as that of his family, for the public good, but he was put to death as a traitor to his order.

A few years after the death of the patriotic king, Cleomenes, the son of Leonidas, succeeded in effecting the reforms which had been contemplated by Agis. A new lease of life was given to the aristocratic State, and the citizens, increased in numbers, were filled with a new spirit of progress and prosperity.

Although surrounded on all sides by powerful enemies, the tiny State retained its separate character for over fifty years.

From this episode in the history of Sparta we may draw the inference that enslavement by a foreign state becomes less and less likely in proportion as citizens emancipate themselves from social injustice. A knowledge of the Secret of History makes plain the lesson that self-determination cannot be said to exist at all for citizens who do not assert the common right to their country, and collect for public revenue the rent of their estate. 


\section{THE GAPTIVITY OF IGNORANGE}

\section{READER'S GUIDE}

A sMall economic model of the taxing system of modern States is put forward, and it is set in motion to show how it grows out of balance. An outlined history of the Roman Empire and the Western States after the subversion is attempted.

\section{The Headings are:}

The War Allotments-The Civilised Struggle for Existence epitomised-The Application to European History - The Struggle for Supremacy in Italy-Imperial RomeThe Neurosis of Captivity-The Gracchi- "The Children of this World, in their Generation, are Wiser than the Children of Light"-From Paternalism to SubversionThe Chaos of the Middle Ages-The Feudal SystemThe Modern Equivalents of Feudal Services-The Deterioration of the Feudal System of Land Tenure"Pull Devil, pull Baker"-Niggardly ProductionEarly Enclosures-War and Poverty-Famine and Desolation-Power and Might reign over Ignorance -The Cross and the Crescent-The Wages of Ignorance is Death-The Revolt of the Vassals-Living More Dangerously. 
John the Miller asketh help to turn his mill right;

He hath ground small, small,

The King's Son of Heaven will pay for it all.

Look thy Mill go right, with its four sails dight, And let the post stand in steadfastness.

Let right help might, and skill go before will, Then shall our Mill go aright;

But might go before right, and will go before skill, Then is our Mill mis-a-dight.

JoHN BALL (fourteenth century). 


\section{THE GAPTIVITY OF IGNORANGE}

\section{The War Allotments.}

During the Great War (I9I4-I8) men and women of Britain were given access to land, and in their spare time cultivated allotments. Rent was paid according to the value of the rods of land occupied, and no one in the interests of self occupied more land than could be put to useful purpose. The destination of the rents, which could not be evaded, need not concern us at the moment.

The local authorities, who were empowered to allocate the holdings, made no inquiry as to whether the applicant possessed capital or skill. Bureaucratic "experts" were not appointed to "organise" or drill the allotment-holders, who in the majority of cases were quite ignorant of the science of tillage; but given the opportunity, the amateurs soon discovered for themselves all the secrets, and enjoyed learning the mysteries of vegetable culture.

The ground was frequently unpromising, sour, hard, uneven, and contained much rubbish. It often grew abundant nettles, thistles and many weeds of long taproots. In its undisturbed state it had become infested with wireworm and grubs, but in a pioneering spirit all difficulties were surmounted. There was no agitation set on foot for the purpose of regulating hours of labour or output, but each was free, and the pleasure of uninterferedwith private enterprise added pleasure to arduous toil. Self-interest was directed to the production of the best quality and the greatest quantity of produce.

A spirit of warmest fellowship sprang up among the allotment-holders, who voluntarily co-operated with each other in a multitude of ways. There were no fences between the plots, but it was immediately recognised that, in order to live in peace and security, it was only necessary to respect each other's rights. 
In the summer a pleasing scene of happiness and plenty in miniature cheered the allotment-holders and their friends. The psychological effect was as beneficial as the material gain to the nation in diminishing the submarine menace.

While the institution of garden allotments will inevitably suffer that derangement which is due to enveloping hostile environment, it is symbolic of a stable civilisation, affording scope to progress and the pursuit of happiness.

\section{The Givilised Struggle for Existence epitomised.}

But let us suppose that the renting of land being unknown, as was the case not many centuries ago, and that the allotment-holders had been rated according to value of produce, for example, so much per pound of potatoes, so much per dozen cabbages and so forth, also that in addition they had been assessed, and asked to pay a fine annually for all cold frames, garden tools and sheds, what would have been the effect of such a rating system upon the production of food, and what direction would the potent force of self-interest have taken?

While it is impossible to foresee every development, it is obvious that in self-interest the compulsory taxes upon production would have been evaded where possible, because this method penalises the inherent desire to progress. Persons who scrupulously paid the dues would soon have found themselves at a disadvantage as compared with successful shirkers, especially when the taxes had been increased to make up short revenue.

In such an atmosphere, honesty tending to be regarded as folly, evasion would have had to be combated by the fears of pains and penalties for delinquents, who would have suffered reproach from neighbours only when found out. Says a high legal authority, "Every man is entitled to take advantage of any technical flaw in law": lawmaking in these circumstances would have required, therefore, the best brains of the allotment community. There would have been a multitude of local enactments, amendments and consolidations, in order to define forceful regulations and to prevent escape from imposition.

The costs of administration rising, there would have been a cumulative effect, which would have tended to push taxation towards the limit of inability to pay more. With 
all these discouragements, it is impossible to imagine a similar scene of profusion to that exhibited under the system of renting. Instead, there would certainly have been niggardly production, and, unaware of the causes leading to this sad state of things, we might have expected to hear wise-sounding theories of "diminishing returns" and that "population tends to outrun subsistence."

It is possible that, as in ancient Sparta, and as in modern Russia by the Marxist Soviets when they "nationalised" the land, an equitable division of the land might have been attempted at the commencement. Many officials might have been occupied in maintaining the division and in restraining the buying and selling of land, but experience teaches that rent, resting upon natural law, cannot be abolished. Individuals will always exploit land-value, unless the community, which creates it by its presence, collects what is the only just source of public revenue. The motive of selfinterest would, therefore, have impelled even the administrative officials to have succumbed to this form of profit-taking.

Disappointed cultivators would have readily disposed of their rights henceforward to be " unemployed," and the successful shirkers of taxes would have taken over the relinquished territory and have become larger landholders, cultivating inefficiently, employing little labour. Later, as the food shortage caused prices to rise, the inactive tillers out of necessity would have become compelled to return and compete with each other for allotments from the large holder, now a profiteer from no special fault of his own. The extreme necessity of the tenants might conceivably have caused them to regard the individual to whom they paid rent for permission to use the earth as a benefactor, and this curious delusion might have been expected to intensify as the rent-collector, in order to obtain higher rents, kept the land market short by withholding land from use.

The profiteer would soon have ceased to be a producer, and those who produced, having now to pay rent in addition to taxes, would have had to toil unceasingly. The rate of taxation would have been high, because the land-withholding would have resulted in so much less total production.

In this artificially evolved hostile environment, distinguished by profiteering and poverty, it is impossible to conceive that a spirit of goodwill would have existed between 
the allotment-holders, nor would those unable to obtain land have been happy. The change having taken place slowly and almost imperceptibly, the steps leading up to the cumulative effects of what seemed at first a fair arrangement would have been obscured by a screen of collateral problems which would have pressed for solution.

The correct solution is one which must go to the root of things. It is not obvious, or at any rate would not have been disclosed for some time. Nevertheless, many proposals, harmful or temporary in their effect, might have been put forward in the meantime. Cliques might very well have been expected to arise favouring antagonistic methods, and much commotion might have taken place without those taking part understanding exactly what it was all about.

\section{The Application to European History.}

This hypothetical system upon which we have speculated is simply a small-scale rough model of the growing edifice of European civilisation, divested of some of its later developments.

In the psychology of captivity a common delusion exists to the effect that only a small proportion of mankind live on land, and that the greater proportion subsist in some other mysterious way. It is also vaguely imagined sometimes that cereals, vegetables and fruits only are produced upon the land, and that houses, machinery, ships, coal and oil have little or no connection with the land. There is a curious mental inertia in some people which requires much effort to overcome before they can get themselves to believe, with conviction, that all things, including ourselves, come from the land and go back again to it; that the sea and atmosphere rest upon the land, which in the language of political economy is a term including them in its meaning.

All that we call wealth comes from land, and wealth is the product of human labour of mind and body applied to natural resources. Even the active power of Nature, manifested in various forces, in growth and reproduction, requires labour to utilise it, exerted through materials grown upon or drawn from land. We can create nothing; we can only grow plants or animals, utilise natural forces, adapt natural products, or exchange so as to add to the general sum of wealth.

Man is a land animal, and any restraint to his use of 
the source of wealth imperils his existence-is a denial of his right to live. Furthermore, if the reward of his labour is taken from him, without due and fair exchange, in proportion as it is so taken man is a slave and his life is in jeopardy.

It is easy, therefore, to understand that when in the early period of European history producers of wealth were expected to contribute larger and yet larger proportions of their harvest to patriarchal priests and rulers, without corresponding return, there was engendered in their minds, despite faith in the gods, a feeling of insecurity and a desire to find a safer environment.

The immediate effect, inevitably brought about by compulsorily taking "from each according to his means," was lessened production of wealth, not only by the independent husbandmen of the fertile plains on the Mediterranean seaboard, but also by the citizens of the coastal towns with whom they exchanged. In due course the " needs" of the peoples (consumers increasing at a greater rate than producers) exceeded their inadequate "means," and a scramble for existence ensued, which enlarged in intensity as time went on.

\section{The Struggle for Supremacy in Italy.}

The story of ancient Hellas, including the decline of Athens, the rise and fall of the harshly administered dominion of Sparta, the subsequent ascendancy of Thebes and the imperialist orgy of Macedonia, is closely similar in many respects to the squeezing, jostling and battling which eventuated in the supremacy of Rome in Italy and the inauguration of the Roman Empire.

We have previously commented upon what seems almost a rule, that when slavery, either of the person or through restricted environment, appears, the natural distinguishing marks due to differences in race, locality, climate, language or occupation become isolating cleavages, and classes and races are no longer merged gradually into each other. Instead, they become egoistical, insular and hate each other, any insignificant irritating incident being enough to endanger peaceful relations.

The fear and suspicion may be most apparent at any one time between peoples of differing races, but more fre- 
quently the unfriendliness distinguishes inhabitants of the same or closely allied race, speaking different dialects or of different religious denomination. There is no permanence in these cleavages, which are due to mental blindness, and which may be between one set of "powers" at one time and another combination at a different time.

The motive which draws people having some common sympathy into close combinations of "power" is due to the feeling of insecurity caused by production of wealth being throttled at its source, and a desire to seek escape from an environment made dangerous unknowingly. Each egoism vainly believes that by subjugating the other security and happiness can be established again.

In ancient Egypt, Assyria and Greece, the egoisms generally centred round some deity or temple, and in Italy, in early times, the pivot was more commonly race or locality. While within each sphere of influence there was continual commotion, the principal struggles were between the Etruscans, the Greeks, the Apulians, the Romans, the Latins, the Samnites, the Lucanians and the Umbrians.

These blamed each other for unfair exchange, e.g. competition in trading, and each combination sought to regulate intercourse in such a way as would advantage themselves at the expense of the rest. The effect of these monopolies was to heighten the illusions which existed, and to give them apparent justification. Great numbers of the population were now engaged in the wars which followed, and in which Rome was finally supreme. Plunder and pillage did not encourage production, and the result was the further impoverishment of the people.

It was natural in these circumstances that Rome should turn her covetous attention to the conquering of her ally Carthage, which had abetted her to dominion in Italy. There is neither gratitude nor gracefulness in exaggerated self-interest, which aims only at the growth and acquisition of power and might. The violation of a treaty, "only a scrap of paper," was the match with which Rome lit the blaze. The circumstances were urgent. "Necessity knows no law" for a desperate Senate in the presence of revengeful bitterness of conquered neighbours and the discontent of famished communities, held together in a loose federation which might at any moment split into two opposing leagues. 
There was no vision provided for the people which might have called forth patriotic endeavour to mutual aid. They had been following the shadow, their heads in the clouds, and they were unconscious of the substance upon which they stood. Iiving in the world of unreality, a mirage claimed their undivided attention only. Carthage possessed a highly developed slave-system, commercial monopolies and the "freedom of the seas." Would not such a venture weld the petty States into one patriotic subject nation? Surely, happiness and prosperity for all lay in the grasp of such a prize!

\section{Imperial Rome.}

The blaze, made white-hot by the hate and zeal of Hannibal, almost consumed Rome herself, but after a long and wasteful war there was ended the independent might of Carthage. "Even this, O Rome, must one day be thy fate!" lamented Scipio, as he gazed upon the smoking ruins of the fallen city.

The spoils of war, never approaching expectation, did not improve the economic situation in Italy. These, such as they were, advantaged the monopolists only; the people were subjected to greater burdens, especially the provincials who could not claim Roman citizenship.

The holders of the homestead plots, cultivators of the ager publicus - " the cornland that was of public right" -discouraged with heavy taxation and burdened with debt, forsook the mortgaged homes and entered the towns to engage in the consuming activities of war, or otherwise to swell the ranks of the idle proletariat.

There was now a dangerous reservoir of unemployed, and the Senate found it necessary to provide a new phantom for the demoralised mob to follow. The pretext that the Macedonians had favoured Carthage was the justification for further imperial brigandage, and economic necessity spurred the apathetic people to action.

Imperialism is like drug-taking, because the dope must be given in increasing quantities or collapse supervenes. The whole of Greece was therefore annexed, ostensibly to "protect" the Hellenes from the predatory Macedonians. The Balkan Peninsula thus became the first great tributary of the Roman Empire. 


\section{The Neurosis of Captivity.}

Dominion was accompanied by the neurosis of captivity. Rome was filled with a credulous, irritable populaceinsolent and idle-fed precariously by means of a corn supply exacted as indemnity from tributaries. The onetime gravity of the patricians was converted into censoriousness as they struggled and climbed upon each other. Family life deteriorated into incontinent self-indulgence. The dignity of the righteous Roman lady became a memory of the simpler manners of the past. She had aberrated into a self-assertive termagant, dreaded by the domestic slaves; or, pursuing sensual pleasure, striving to still the never-to-be-satisfied cravings for a happiness put out of reach, she sought new sensations in sybaritic orgies. The wanton was held in high honour in degenerate Rome.

Youth, born into a feverish environment, impatient of learning, was infected by the hectic vainglory of Boast and Pomp, and assisted the national insanity by adopting and extending the cruel sports and vices of the vanquished Carthaginians.

Accompanying the hard parasitic struggle for existence came gaunt famine, and thousands of the people, unaware they were "living dangerously," were carried off by starvation and pestilence.

\section{The Gracchi.}

But amid the alternating violence and depression of the scrambling, quarrelsome multitude there were those who attempted to discover and apply real remedies to the curing of the social ills which beset the Republic.

"Men of Rome," said Tiberius Gracchus, "you are called the lords of the world, yet have no right to a square foot of its soil! The wild beasts have their dens, but the soldiers of Italy have only water and air!"

The holdings of the once-free husbandmen had aggregated into the latifundia of senatorial families. Agriculture, so far as it was practised, was carried out by tribute-paying colonii, whose methods impoverished the soil. The great estates for the most part were given over to pasture, the shepherding being performed by gangs of slaves, locked up at night in underground prisons. The country-side was otherwise 
almost depopulated, and in this wilderness wolves supplanted men.

The Gracchi, in the face of senatorial opposition, attempted to revive the ancient Roman virtue by restoring the Licinian Law and its subsequent divisions of the land. Outlawed as tyrants, undefended by the cowardly rabble, the patriots were killed by the profiteers, but the redistribution of the land, so far as it was carried out, saved the State temporarily from collapse.

The idea of absolute ownership was preserved by those who bought and sold land, and allotment-holders themselves, in time and on occasion, succumbed to the false philosophy, becoming petty landlords. Landholders everywhere, in a natural but vain desire to secure a durable tenure, asserted claim to dominion where they should have been content with usufruct.

Nevertheless, the check given to monopolistic spoliation at the commencement of the hundred years' revolution straightened the path to the further limitation of the power of the oligarchical Senate towards the end of that period. Before Julius Cæsar suffered the same fate at the hands of the reactionaries as the Gracchi, he made adjustments in taxation and representation which materially cut down privilege.

Had these partial reforms not taken place, there would have been no Roman Empire to endure fitfully five hundred years.

\section{"The Children of this World, in their Generation, are Wiser than the Ghildren of Light."}

Those greatly desiring freedom frequently forget that nations are not kept in thrall by either oligarchies or tyrants. In the last resort, it is ignorance which alone is responsible for the perpetuation of slaveries.

But until the captives learn that the door opens inwardly they will continue to use force to push it outwards. Governments represent the reaction which results from the employment of wrongful means to obtain liberty. Government based upon force is the door devised by the "children of this world" to restrain indiscriminate anarchy, and government is made more frightful and ruthless as the subject nation becomes more tumultuous, in the hope forlorn that law and order may thus be preserved. 
In this sense it may be said to be true that " A nation possesses the government it deserves."

But Power and Might endure for a brief season. Nature ordains that the inherent desire for freedom increases at a greater rate than the building up of any restraint invented by man.

\section{From Paternalism to Subversion.}

Cæesar Augustus, pater patria, provided food and amusements for the citizens of Rome, much as peevish children are pacified momentarily with lollipops and toys. Meanwhile, behind the screen of paternalism a new despotism was founded, mild at the commencement, but infernal in its consummation. The grasping power of the patricians was curbed, but an unbridled militarism developed which more than replaced the tyranny of the Senate.

The latifundia, which had been the curse of Carthage, also ruined Italy. In Sicily, Africa, Spain and Gaul also, great estates were carved out for the military conquerors, who became absentee landlords, employing tenants and slaves where once existed hardihood and sturdy independence.

Barbarians, living peaceably under a primitive organisation which allotted shares of cultivated ground and the common use of pasture, were pushed back by Roman legions, or they entered those legions against their own kin who were struggling to retain possession of the land.

It is the soldiers who are the first victims to be laid upon the altar of Injustice worshipped at by the community living in the paradise of fools. Organised warfare is believed to delay, for those left at home, the inevitable day of reckoning to account for social maladjustment. The brave men who sacrifice themselves are highly esteemed, especially when danger threatens, even by the meanest, who basely seize the time of grace as an opportunity in which to plunder their neighbours.

But soldiers, in common with all mankind, inherit the universal desire for freedom, which must outlast Power and Might or the human race perish. And so, as despotism deepened, indiscipline developed among the Roman cohorts. Power and Might then employed barbarian levies to preserve order at the rotten heart of Rome, and the Prætorian 
Guard, who had sold the public offices, including the Imperial chair and purple, to the highest bidders, was finally abolished, the mutinous troops being banished to the borders of the empire.

The Roman Empire embraced the world, but it was merely a hollow shell of dominion. It was the resistance of the healthier life at the frontiers, where the green sap of liberty yet flowed, which delayed collapse. The heart was eaten out of the great empire, and this result was brought about by the operation of the false principle that "the State is entitled to take what it chooses." The inevitable anticlimax came; the dispossessed barbarians at length broke through.

"Rome perished from the failure of the crop of men." She had placed Property before Humanity and Culture before Justice.

\section{The Chaos of the Middle Ages.}

For several hundred years the fragments of the Roman Empire continued to struggle and fight with each other, unconsciously striving to establish a rule of the land. The subversion of the empire enabled the primitive allodial system of land-tenure to revive, the approximate justice of which is the reason for its persistent survival, in Russia beneath absolutism and serfdom, in Serbia in spite of Moslem oppression, and in India although cultivators have been under the heel of imperialists for centuries.

But the purely agricultural age in Europe had passed. Progress in the arts and in commerce necessitated closer associations between men, with greater numbers in selective voluntary co-operation at a given time. The allodial system and the frequent distributions of land in this and similar schemes of land-tenure disturb any but the most temporary improvements. The march of progress into wider and more complex undertakings than agriculture was hindered, and a strain was set up in human society which manifested itself in friction.

Evolution in credence takes place, and new ideas prevail, to become common property whether consciously advocated or opposed, though empires rise or perish. The institution of chattel slavery, relic of the pastoral age, reached a climax 
in Europe at the subversion. During the Middle Ages dissimilation set in, and at the present day, although human life is conscripted into military slavery, the buying and selling of human flesh and blood is regarded with detestation.

During the dominion of the Romans the buying and selling of land, which was invariably associated with the slave traffic as a later ally, was stimulated by the operations of the usurious "publicans" or moneylenders. After the subversion of the Roman Empire, like the slavery of the person, the slavery of the private ownership of land received a serious set-back also, but that did not result in extinguishing it, because the feudal system, which came out of the melting-pot, and which was a great advance in land settlement, did not provide completely for advancement in the arts and in exchange. It early became obsolete; again there was a strain set up in human affairs and consequent commotion.

\section{The Feudal System.}

The feudal system-a blending of the idea of common rights in the soil with the idea of exclusive property-was born of the ruins of the Roman Empire.

The effect of the reactive migration of Teutonic tribes during the fall and collapse of Roman dominion is worth noticing. These tribes were carried by their impetus far beyond their ancient domain, to overlay the Romanised Ligurian or Gaulish tribes.

Demoralised and impoverished by the effects of the Roman culture, the Gauls were unable to absorb or to repel the virile franklins of the North, who were innocent of the evils of the latifundia. While in the South of Europe Roman law survived, in the centre a change took place in the platform of thought and custom which had lasting effects. The fusion of ideas held by the Franks, and represented by the allodial system of cultivation, with those of the Gauls, accustomed to the absolute ownership of the person and of land, resulted in what afterwards developed into the feudal system.

The more civilised but servile Gauls became the tenants of the uncultured Teutons, who showed, nevertheless, greater humanity towards them than their former masters. It is true that the Gaulish or Welsh prisoners of war were 
enslaved as a reprisal, but only after great provocation and treachery; in general, and in accordance with the meaning which tradition attaches to their name, the Franks were peace-loving and ready to forgive.

Owing to the comparative isolation of Britain, the development of the feudal system took place more slowly there than on the Continent, but the island was subjected to many separate incursions or backwashes of Teutonic tribes, Saxons, Jutes, English and Danes, at different periods, caused by the fluxing circumstances on the mainland. Thus it happened that side by side with each other there existed for some centuries conditions of social life in England which marked the punctuation of each step taken in the development of the feudal system. In the north and middle of the country, franklins or freeholders brought the land back to cultivation, feeding the famine-stricken population thereby. In the south or Saxon England the feudal plan probably reached its most beneficial form in the time of the great King Alfred, who did so much to establish a system of local government and public service, the efficiency of which has not since been approached.

"Land was granted to individual possession, yet in its possession were involved duties, by which the enjoyer of its revenues was supposed to render back to the commonwealth an equivalent for the benefits which from the delegation of the common right he received." (Henry George.)

The changing of an absolute tenure, as in Roman law, into a conditional tenure upon the feudal plan was a rude approximation to a just Rule of the Land. The liberation of action it afforded was immediately reflected in the progress made in every direction that mattered.

The Crown lands supported public expenditures which are now included in the Civil List; the Church lands provided for education, the care of the sick, the fatherless and the widow; while the military tenures ensured the defence of the realm.

\section{The Modern Equivalents of Feudal Services.}

Misconception is inevitable if feudal services, because they were given as a condition of freehold, are understood to mean literally the equivalent of rent of land. It is more 
correct to regard such fees as comparable more nearly with the modern income and other direct taxes.

Many students, who are under the impression that income taxes, death duties and the increment duty are of modern origin, will be interested to learn that all these devices for the legal plunder of the community by governments have their counterparts in the obligations of the feudal system. The change from feudal times resides in this fact, that those who pay the bulk of these taxes do not necessarily possess " a stake in the country," and that those who do possess a freehold do not pay as a condition of tenure.

Death duties are in effect the old fines for relief and primer seisin, and the exorbitant fine for a licence of alienation is the increment duty of the feudal system at the time of its decay.

It is obvious that there was a period, as, for example, in England before the payment of the Danegeld, when the feu approximated to the rent of land occupied by the landholder, and this was when the system existed in its most desirable form. But, as we have attempted to show in the economic sketches of Egypt, Chaldæa, Hellas and Rome, there is a fundamental injustice in the taxation according to ability to pay which becomes apparent in the culminating effects.

\section{The Deterioration of the Feudal System of Land Tenure.}

It is remarkable that deterioration was brought about in a manner reminiscent of that which caused the derangement of land settlements earlier in the world's history.

A fief was a trust in its inception, but gradually the principle of primogeniture and entail developed, and although feudal law required that there should always be some representative of a fief in wardship capable of discharging the duties as well as of receiving the benefits which were annexed to a landed estate, trusteeship became dominion, as the apprehension of the land as common property was compromised.

Nevertheless, since the process of infeudation consisted of bringing individual manorial dominion into subordination to the superior dominion, i.e. the crown, which represented the larger community or nation, it was held in English law, 
centuries after the Conquest, as a changeless principle (according to Coke and Blackstone) that all land is holden mediately or immediately of the king. That is to say, possession is not ownership and no one can own land ; that all land is subject to old charges, services which transfer cannot remit.

In modern times, as in the days of the Roman Republic, the philosophy of ownership has been so falsified that freeholders not only think they can sell land to each other but even to the State itself, apart from the just compensation for improvements.

\section{" Pull Devil, pull Baker."}

It was to the interest of the Saxon thane, and in later times to the Norman baron, to obtain wherever possible increased dues in money, services and/or kind from the sub-tenant. While he resisted feudal dues to his superior, who was continually in need of funds for " preparedness," the crown tenant employed prisoners of war as slaves, and sought to lay greater burdens upon the peasant. In this way he contrived a margin for the increase of his own power and magnificence, and evaded giving corresponding services to anyone in return.

The peasant was willing to pay rent for the opportunity of tilling the lord's domain, because the feudal estates were better lands than the commons, but he had no measure of his obligation. The dues for tenant and sub-tenant were arbitrarily fixed, roughly upon the basis of " ability to pay." Economic rent, that standard which everyone could recognise as just, arrived at by free competition conforming with the natural law of Equity, was unknown.

There being no Rule of the Land, it was " pull devil, pull baker" almost from the commencement. The tax tended to be pushed far beyond the economic rent for the sub-tenant, who, being the weakest, had to surrender, because, having no rule by which to measure the wrong, he could not protest effectively. The repressed rage of the peasant was given an outlet for expression in the feuds between the idle, quarrelling nobles, and it was vented upon other peasants similarly aggrieved. Their state was not improved, but worsened thereby.

While not engaged in private wars with each other, or 
in league against the overlord, the nobles joined together whole-heartedly and made common cause against the peasants when they tried to get better terms by moving to other estates, or by joining the communities of yeomen and franklins who tilled the extensive commons, not then enclosed. It was then that Power and Might enacted that the cultivator might not leave without the lord's permission.

The atrocities which inevitably took place during the feuds and civil wars burnt into the minds of the partisans, who felt now they had a real justification for hating each other, though it became plain that formerly they had been misled into taking sides by lies cunningly told by interested gamblers. Disunited and blind to their own interests, they were serfs caught and bound by a "leaving certificate."

But while the married man with a family might be held in this way, it was otherwise with the enterprising young men, who began the exodus from the country to swell the growing towns as artisans, fishermen and traders.

\section{Niggardly Production.}

The peasant soon found by experience that any improvements in utensils, appliances or methods were watched with covetous eyes by the lord, who took every possible opportunity to absorb the increased production by increasing his tax. Indeed, the industrious peasant earned the dislike and contempt of his neighbours when he again plucked up courage and put forth increased effort. It was found that no one benefited save the lord.

The discouraged sub-tenants resorted to slovenly living and to restriction of output, and the growing poverty was intensified by the withdrawal of labour from healthy production to the activities which lead to war, pestilence and famine.

\section{Early Enclosures.}

The folk-land or commons, many millions of acres reserved for the yeomen, were secretly conspired against by the king's " wise men." The presence of these free lands made it difficult, despite feudal enactments, to force up tributes. In the South of England, therefore, land not parcelled into holdings was granted by the king to henchmen, thus putting up a barrier to the natural expansion of allodial communities, and the existing cultivators became subject to feudal dues. 
But in the Danelaw the patriotic bishops braved the wrath of the nobles and supported the yeomen in asserting their independence. Comparative prosperity and peace reigned in the Danelaw.

\section{War and Poverty.}

All over Europe, even to Norway and Denmark, the same changes were taking place. Danish peasants, escaping from an environment made hostile by taxation according to " ability to pay," found sanctuary, along with refugees from Saxon England, among yeomen of the Danelaw, descendants of common ancestors.

On the other hand, the struggle for supremacy which was going on during the so-called Heptarchy in England was also proceeding on the Continent. The vikings or sea rovers of the tenth century, who raided the coasts of Germany, Gaul and the British Islands, were mostly dispossessed profiteers, who desired to repair their fortunes by plundering and possessing the "golden lands" settled formerly by their kith and kin of freer days. Niggardly production intensified by incessant civil war produced the Great Famine of A.D. 976.

\section{Famine and Desolation.}

The people were blind to the real cause of famine, and blamed each other for eating too much or for withholding supplies. The English and Saxons thought the food and clothing shortage was owing to the presence of the Danes living in their midst. In such a strained mental atmosphere the lying tale of King Æthelred, that the Danes were about to betray him and his wise men and take the kingdom, was all too readily believed by a suspicious people smarting under the attacks of the vikings. The terrible massacre of the Danes was the result.

\section{Power and Might reign over Ignorance.}

Chattel slavery throve again, because more left the country than could become freemen of the towns. The unemployed, compelled by the pangs of hunger, sold themselves or their children for food. Others, made desperate by extreme poverty owing to the rising cost of living due to niggardly production, became robbers, and were sold, when captured, into slavery along with other criminals. Crimes increased as oppression intensified. 
In England a brisk traffic in slaves was carried on between Bristol and Ireland, London and Gaul.

Life and property were insecure, and in the dangerous environment which had developed it was natural, not tracing the cause clearly, that men should seek, for protection, the frank or peace-pledge of a lord. The barons, dukes and earls, in their turn, were either ruthlessly broken or came voluntarily into the great military trusts or combines of Power and Might, doing homage to head-kings or emperors.

It was not inordinate ambition which was the root motive for the acquisition and use of power. The people ardently desired peace, and thought that only by means of "strong" government could this be attained. It was for this reason that Cnut of Denmark, who was a modest man, was invited to England. When resistance was put in the way of his acceptance he fought, in order, as he thought, to rescue his friends.

The conduct of William of Normandy, who saw that success apparently crowned a centralisation of power, may seem more open to criticism, but doubtless even in his case ambition was secondary to the benevolent desire to confer a benefit on those round about him, embued as he was with the belief that he was the man of the moment. To prevent the disorderly natives of Britain from killing each other, was not a stern ruler necessary? Was it not plain that they were incapable of governing themselves?

It seemed to everyone living in those times that men could only be made virtuous by force, and the Church, in its solicitude for the welfare of the laity, made the saving of men's souls subordinate to the ruling of their bodies. Bishops often occupied the chairs of magistrates and abbots were great landowners; it was not long before churchmen were soldiers.

The Papacy, with its hierarchy of bishops, priests and deacons, had a universal hold upon the superstitious imagination of the people of Europe. It was at this time in a strong strategic position for European supremacy; the most democratic institution the world has ever seen was to head a league of chivalry-incongruous alliance of cross and sword.

All who were "living dangerously" were eager to do homage to the Pope. Blessed by the Church, there seemed security for those who wished to legitimise what had been the price of blood. Charlemagne contributed his temporal 
power to the "spiritual" power of Rome, and received his crown as Emperor at the hands of the Holy Father, after the overthrow of the Lombards.

In a desire to secure a durable peace, an attempt was made, headed by the Pope and Charlemagne, to put an end to the private wars of the barons and free towns, but the Rule of Peace, like "the Truce of God " two hundred years later, proved a disappointing failure. War cannot be Christianised by conventions, even though imposed by a supreme archangel! It is the temptation of Satan in the wilderness!

It is said, alas! within a few years two archbishops and eight bishops died on the battle-fields, fighting to make an end of war!

\section{The Cross and the Crescent.}

The interests of the discordant elements of the Holy Roman Empire were in too great conflict for the tie of common superstition to hold except for a brief spell. The league of chivalry seemed on point of segregation when, almost miraculously, so it seemed, the objective appeared which should give dynamic stability and associate Christendom as one.

As parasitism sprang up, tending to choke the new gospel of liberty according to Mohammed, a competing egoism was created out of the ruins of the Eastern Empire which centred round the crescent as a symbol. The Saracens and Turks had undertaken to rid the world of idolatry at the edge of the scimitar about the same time that the powers of Christendom were engaged in trying to make it righteous at the point of the sword.

"Freedom" to exploit the trader using the Orient routes was one of the prizes competed for by the interests of each side, and commercial monopolies of Mediterranean seaports provided interesting sideplays during the crusades, as well as the opportunities for profiteering afforded in the supply of food and munitions to thousands of men journeying through Europe to the wars.

By an apparent coincidence, the objective which seemed so desirable to the league of chivalry also was acceptable to zealous Moslems, who welcomed the common danger as a means of drawing into closer association the three divided caliphates of Bagdad, Cairo and Cordova. 
The mill of destruction was ready for the aberrated captives of ignorance; it only remained for it to be set in motion. Preaching at a great gathering in France, the Pope told the story of the injuries and insults accorded to pilgrims who visited the Holy City, and exhorted his hearers to " go and deliver the Sepulchre of the Lord." His sermon was received with shouts of "God wills it! We will go!" and thousands of all ranks, sewing a little cross on their left arm to attest their promise, vowed to go and fight to liberate the Holy Land from the infidel.

\section{The Wages of Ignorance is Death.}

For two hundred years the "overpopulation" of the East and West, each side feeling inspired with an exalted purpose, committed suicide in the crusades. Disillusionment came slowly. The Westerner found it difficult to believe that the dragons and monsters were the hallucinations of a diseased imagination and that atrocities were not the monopoly of the Mohammedan.

It was, nevertheless, a shock for the pious Crusaders to discover the nakedness of Rome and to realise that the Saracens could teach lessons in honour, courtesy and mercy. Nor was it easy to convey such an unwelcome truth to infatuated captives of superstition at home. But they eagerly learnt all that the enemy could teach in the arts of war. The barons, in possession of this knowledge, more securely underpinned their power by the construction of strong castles, and the whole of Europe became an armed camp, or series of strongholds from which oppression could radiate.

There is, however, no evil from which good does not emanate. It was by means of this channel of activity that a flickering revival of knowledge was made in mathematics, astronomy, medicine and engineering. The peasants, wage-earners and slaves had little share in this new knowledge. With everyone in conspiracy against them to take all that could be regarded as surplus wealth, there was no encouragement to progress. Their surroundings were indescribably filthy and insanitary-fever and famine accompanied each other through the land.

The rulers of Europe were in heavy debt to wealthy townsmen and to each other. Vassals were in arrears with their feudal dues and were also in the bonds of usury 
to moneylenders. Many of these latter were Jews, and popular feeling was hostile at the thought of fighting for their country. Hundreds of the "Peculiar People" were therefore cruelly massacred, together with their friends and families.

\section{The Revolt of the Vassals.}

Feudal dues had been increased and augmented by tithes, fines and scutages to meet the abnormal expenses of the wars. Up to a point, the barons and knights had been able to pass on a proportion of these burdens to their tenants, but it was soon discovered that there was an economic limit to this process beyond which it was impossible to go. Taxation of the cultivators having reached the position of inability to pay more, the total value of the revenue diminished as imposts increased, because the production of wealth was increasingly discouraged.

From time to time hatred almost ceased to burn between the rival upholders of the Cross and the Crescent. All over Europe the high and pure ideal of the fraternity of men and nations was set aside and forgotten in new and more bitter class hatreds. In England, in Stephen's reign, the king's power was impotent, and the barons resumed their indiscriminate warfare, segregating into opposing unstable factions, either fighting to subjugate one another or combining against the king and his party to resist payment of fees to the crown.

During John's reign the nobles and commoners, finding for a brief period that their aims were identical, wrested from the king the Great Charter of the Liberties of England. In it, in addition to other limitations of power and a repudiation of debts, the feudal rights of the king over his vassals, and of these vassals over their tenants were limited and fixed.

In this way it transpired that the landholders became possessed of the value of land, in so far as it exceeded the feudal obligation of the Charter, and this increment increased proportionately as population increased. But this arrangement only remained stationary in the case of peasant holdings, the tenancy at will hardening into a tenancy by copy or custom. The crown tenants took an early opportunity to introduce indirect taxes upon production, and to evade altogether their direct feudal obligations. They 
gradually assumed ownership of the estates they held and complete dominion over their tenantry.

\section{Living More Dangerously.}

We are supposed to have been oppressed in the past by tyrannical kings, but this supposition is far from being wholly true. The kings of England, for example, during the deterioration of the feudal system, struggling to bring the lawless nobles within the jurisdiction of the civil courts, have been frequently on the side of justice and liberty upon occasions when historians accuse them of the exact opposite.

When Edward I authorised his judges to inquire, under the writ called Quo Warranto, by what right the lords held the private jurisdiction which they claimed, the Earl of Warenne pulled out a rusty sword, saying, " See, my lords, this is my warrant. My ancestors came over with William and won their lands with the sword, and with the sword I will keep the same against anyone that wishes to seize them. For the king did not overcome and win this country by himself, but our forefathers were with him as partners and helpers."

This "patriotic" outburst should be compared with the clarion call of Tiberius Gracchus to the men of Rome. There is the same note of feeling in each, but while the latter is honest currency, the former is spurious coin. The nobles, in fancied security in their strong castles, had now conveniently forgotten that they alone could neither win nor hold, and that they also had partners and helpers. The claim of Might over Right is a dangerous doctrine, and so it proved in actual practice.

In England the old nobility was practically extinguished in the continual private wars, culminating in the Wars of the Roses. The present nobility are mostly descendants of moneylending shopkeepers and bankers. In France a similar fratricidal struggle took place until the time of Louis XIV, and what remained of baronial power and might was ended by the guillotine during the Terror.

Any social institution which cannot be referred to the operation of free and equal opportunity for all will not stand the test of time. The fundamental inequality in any approximation to Equity culminates and is multiplied, until the whole structure of society stands upon an unstable foundation of injustice. 


\section{THE SLAVERY OF MONOPOLIES}

\section{READER'S GUIDE}

IN Chapter XIV slavery and monopoly are clearly defined. The developments in the industrial and capitalistic system are traced from the time of the Black Death until the abolition of the Corn Laws in England.

\section{The HeAdings ARE:}

A Complete Monopoly-The Wage Slave-The Employer not more to blame than the Employee-The Lesson of the Black Death-How the Peasants were recaptured -The Armed Resistance of the Peasants under Wat Tiler-The Cordon tightened-Poverty reappears-The Struggle of the Estates-The Crown consumes the Church Estate-The Attempt to re-establish Chattel SlaveryAgrarian "Rebellions "- The apparently Miraculous Escape of the Landlords-The Divine Right of the King becomes the Divine Right of the State-The Theft of the Immature Fruits of Liberty-The Desirability of Thinking in Terms of Labour instead of in Terms of Money-The Philosophy of Ownership-The Constitution of the Modern Capitalistic System-The Rise of the Farmer Capitalists-The Decline of the Farmer Capitalists-The Disaster to the Capitalist Farmer. 
True Freedom lies where a man receives his nourishment and preservation, and that is in the use of the earth. All that a man labours for, saith Solomon, is this, That he may enjoy the free use of the Earth with the fruits thereof. . . .

And now say the people, Is not this a grievous thing, that our brethren that be Land Lords, right or wrong, will make Laws, and call for a law to be made to imprison, crush, and, nay, put to death any that denies God, Christ and Scripture; and yet they will not practise that Golden Rule, "Do to another as thou wouldst have another do to thee," which God, Christ and Scripture have enacted for a law. Are not these men guilty of death by their own law, which is the word of their own mouth? Is it not a flat denial of God and Scripture?-Winstanley (The Digger, time of the Commonwealth). 


\section{THE SLAVERY OF MONOPOLIES}

\section{A Complete Monopoly.}

Chattel slavery is the most complete monopoly which exists. It is a form of servitude in which the slave is fed, clothed and housed by his master, not as a just return for services, but because it is the minimum upon which a captive can exist and reproduce. Captivity not being conducive to longevity, the birth-rate is an important consideration for the slave-owner.

A mean master might cut the essentials of subsistence down below the standard of "healthy animality," but it would not be to his advantage to do so, because it is evident that the slave would become too weak to work, also his progeny, although they might arrive frequently, would perish early from malnutrition. Consequently a slave-owner cares for his slaves much as he cares for his horses or other domestic animals which have an exchange value.

The benevolent master might show great affection for his chattel, might shower gifts upon him, might dress him in the costliest raiment, feed him upon the choicest food, but the slave is yet a slave-a captive in a cage of gold. He has no right to himself, does not possess the product of his labour, cannot enjoy in security the pleasures of his family. $\mathrm{He}$ is restricted and monopolised entirely by his master, and he is not happy and contented.

Self-interest being thus circumscribed, it is obvious that little enterprise of a beneficent nature would be exhibited by the slave, who would devote his main energies towards the currying of favour with his master and overreaching his fellow-captives.

In such surroundings of hostility a small spark of annoyance might conceivably promote panicky and violent action, which would be repressed severely by an overanxious 
master, against whom a feeling for revenge would be nurtured. In practice, our expectations that progress in invention would be meagre, except in channels of luxury, immorality and superstition, are fully borne out by past experiences which are recorded in history.

\section{The Wage Slave.}

The act of receiving recompense in kind, in corresponding services, or in being paid a token in money which will command the labour of others to an equal amount, does not constitute slavery. Nor, because one man employs another for wages, is the employee a slave. But to the extent that the employee is paid less than the value of the services he renders to his employer, so he is enslaved. Conversely, if the employer pays more than the value of the services rendered to him by the employee, to that extent the employer is a slave.

There is no slavery when a just and equal bargain can be struck. There is nothing inherently immoral in the use of money, which is a labour-saving medium for the exchange of wealth, and in purchasing commodities in exchange for his money wages the employee determines the labour of others to the satisfaction of his needs.

The employee thus becomes in turn the employer.

But if the bargain for employment must be closed by the employee, who knows that the failure to close means the risk of starvation, then he is at a disadvantage, and is compelled in an extreme case to accept what will only command a bare subsistence. Similarly, if by reason of an artificially made "short" supply of commodities the consumer, i.e. the employer, is compelled to pay " profiteer" rates, then he is at a disadvantage, and in an extreme case may not be able to purchase sufficient for his daily needs.

Artificial " overpopulation," caused by the elastic steady pressure of forced migrations into NARROW SPACES, owing to its being superstitiously thought that land, which is the " means of life," may be monopolised by the few, is the reason why men and women are compelled to sell themselves cheaply and to cry, often vainly, in the markets of flesh and blood, "Who will buy us?" The slave-driver's whip is not so cruel as the pinch of hunger in the sight of 
tantalising provisions, hearing in one's ears the cry of little children for food.

The jostling "landless," hurrying and jumping upon each other, are being ground into poverty between the upper millstone of niggardly production and the lower millstone of forced labour sales. The "National minimum wage" represents the nearest possible escape from the sieve of starvation.

Wage slavery is based upon the restriction of output, on the one hand, and the ever-present reservoir of unemployed, living casually and dangerously, on the other. It is their clamour for work, and their competition for the jobs held for the time being by others, which operate so as to bring the wages of all the unskilled to the subsistence level. It is due to this fact that we see persons filling the most unpleasant or arduous occupations for the same wages as others receive for lighter and more congenial tasks.

Those who "must keep up appearances" and those whose higher skill or exceptional knowledge command a higher minimum do not escape from the consequences of the common hostile environment.

The slope is a slippery one, and all labourers of hand and brain are compelled to engage in the warlike competition of doing, so far as possible, without the necessities of the life they lead.

In the unnatural alienation of man from Mother Earth we find the explanation for the so-called "Iron Law of Wages" of Karl Marx, and we know, moreover, that the phenomenon is only the manifestation of a hide-bound superstition.

The wage slave is only different from the chattel slave in the limited freedom he is afforded in the society of his family, in the disposal of his wages and spare time. $\mathrm{He}$ runs less risk of flogging and imprisonment in leaving one master in the attempt to find a better one. Possessing no exchange value, however, the wage slave might even envy the lot of the chattel slave, who is cared for in order to fetch a good price when his master can no longer employ him.

But, equally with the victim of personal slavery, the enclosed wage slave has no title to himself and is the mono- 
polised victim of restricted immediate environment, although he may be, and generally is, quite unconscious of the fact.

\section{The Employer not more to blame than the Employee.}

The employer, in view of chronic unemployment, in the offering of minimum wages or less, is no more to blame for poverty than the employee, forced to accept. While he can, a wise employer may pay a degree more than the minimum or trade-union rate of wages in order to buy the pick of the market to his own advantage, but there is a limit beyond which he cannot go, because, as the "employee" of customers who employ him, his services may be dispensed with and the work placed with persons who can accept a lower price by paying minimum wages to their "hands."

The employer of wage slaves, therefore, is at best only a superior slave overseer. $\mathrm{He}$ is the warder of the enclosure made by land monopoly.

\section{The Lesson of the Black Death.}

It should be scarcely necessary to remind the thoughtful reader that the miserable condition of a people is not fundamentally due to the oppression by certain of them, called rulers. It would be impossible for the few to tyrannise the many, were it not that the latter are persuaded that it is desirable for the common good.

Oppression is the resultant of all the oblique actions and reactions of the individuals of a society, which in general subscribes to some distorting superstition that causes the obliquity. There have been at different epochs in history occurrences, which in a marked degree have demonstrated how impotent man-made arrangements proved when the operation of a superstition was lightened temporarily and suddenly by changed circumstances.

The Black Death of the Middle Ages, brought about by the terrible insanitary conditions of the unprogressive peoples, who had condemned themselves to slavery and disastrous wars, was such an occurrence.

While the whole of Europe was affected, the sparse population of Britain was reduced suddenly to about onehalf. We have already briefly alluded in a former chapter to the economic effect which followed before the land- 
monopolists had time to close in the barriers upon the diminished population.

The lucid interval was enough to show how vain was the delusion that maximum and minimum prices of land, wages and produce could be fixed by legislation, or that there existed an "iron" law of wages on the supposition that it was a fund paid out of capital-bugbear of obsolete political economists.

Plague is no respecter of persons, and whole families of landlord barons, nobles and copyhold farmers were blotted out, along with thousands of hired freemen, slaves and villeins. Unclaimed land was taken possession of by the labourers, who refused to work for the surviving masters for less wages than they could make working for themselves. Many masters therefore entered into partnership with hired servants.

Slaves and serfs ran away from their lords and became free labourers. The competition, instead of being men for jobs, became one of employers competing for the services of employees. Wages rose rapidly, in spite of the Statute of Labourers and threats of severe penalties directed against the employers who offered and the labourers who accepted wages above a certain maximum.

In self-interest, employers were as ready to cheat the Government measures as the employees, and wages rose to the limit where their value was equal to the product of the labour expended. In self-interest all combined, and were encouraged because the reward remained theirs, to substitute profuse production for niggardly restriction of output.

Although wages were high, food, clothing, housing and other labour products were in comparison low in price, because they were plentiful. Profiteering cannot be carried out in the midst of profusion.

In the surroundings of general prosperity, which is a great emancipator, slavery melted away, and a hundred years after the pestilence not a serf remained in England. The end of the fifteenth century was the Golden Age of Labour: "A peasant could provision his family for a year by fifteen weeks of ordinary work, and an artisan in ten weeks." (Thorold Rogers.) 


\section{How the Peasants were recaptured.}

But because the barriers of dominion were allowed to remain, the cordon was gradually drawn in, the peasants holding land themselves assisting in the process. Nevertheless, having had a brief experience of comparative freedom, the population could not be imprisoned at once and to the same extent as before, and struggled to escape as they felt their liberty curtailed.

Constituted authority in the Church and State made every effort to keep alive the superstition that one man could own another and that the State was entitled to tax what it chose. Anarchy and violence accompanied these aberrations of intellect.

In France, after the Battle of Poitiers, the attempts of the nobles to tax away the new prosperity of the peasants were met by a great revolt. It was at this time that the Black Prince, of sinister reputation, and Captal de Buche suspended hostilities and united their forces, composed mainly of peasants, in order to chastise the Jacquerie; just as in I525 the French soldiers drawn from the peasantry under the Duke of Guise combined with Charles the Fifth of Germany to punish the cruelly oppressed boors.

\section{The Armed Resistance of the Peasants under Wat Tiler.}

The first poll-tax made during the French Wars of Edward III was easily collected, because the deluded English people imagined that their taxes would be paid by the foreigner, but the second tax, imposed when Richard II came to the throne in order to pay back war loans to moneylenders, was not popular when this mirage had dissolved.

The brutal methods of the tax-gatherers fanned into flame the smouldering discontent against the heavy tolls, market dues, and the vain attempts which were made to keep down wages and to perpetuate slavery. But the mistaken violence of the uninstructed mob under Wat Tiler, a returned soldier, did not accelerate liberation: it only prevented them from seeing the road to freedom. The useless appeal to direct action ended in the murder of Wat.

Instead of the fulfilment of promises probably made in 
good faith by the youthful king, the landlords, during the period of demoralisation which followed, took a bloody revenge. After spreading tales of the atrocities which the mob had perpetrated, or were about to perpetrate, the monopolists had hundreds of insurgents and their leaders slaughtered as a terrible example.

\section{The Cordon tightened.}

In spite of legislation backed by cruel penalties, wages continued to rise and the relative cost of living to fall. The landlords dimly saw at length that in order to increase custom or tenancy dues they must make a "corner" in land.

Many of the vacated estates had been already resumed by the king, ostensibly as crown trustee, but really for the benefit of himself and favourites. This royal example was not lost upon the noble lords and their smaller imitators The claim of the latter was not, however, esteemed so valid when the larger grabbers began to eat up the small holdings.

The robbery and corruption which went on as the cordon was drawn in upon the people was the subject of unceasing protest, but it was ineffective because it was not accompanied by any practical solution. Although the country gentry and the peasants under Jack Cade defeated the royal forces, the distracted victors were put off with empty promises by Constituted Authority, and the movement collapsed when Jack Cade was assassinated.

Long after the legislation introduced, during the reign of Henry VII, to prevent further enclosures, the scramble proceeded, until in the end the landlords quarrelled over their spoils and began to steal from each other. It was this which in reality brought about the long Wars of the Roses and established the supremacy of the kingship. The moral power of the barons, backed by the commons, which in the time of Simon de Montfort had limited the power of the king, was swallowed eventually by Divine Right and Passive Obedience.

\section{Poverty reappears.}

The land monopolists, in order to evade the payment of higher wages, now converted arable land into pasturage 
and raised sheep in large quantities. In the sixteenth century the new fashion of sheep-farming had proved so remunerative that, in spite of the export duty on wool to replace the diminishing fees of feudalism, the landlords could not resist the temptation to enclose the pasturage of the commons and to seize the lands of the copyholding freemen when the latter resisted the payment of higher custom.

Whole villages were depopulated, churches fell into ruin, and although attempts were made by Parliament to limit the number of sheep, so as to provide elbow-room for men, and although legislation was passed to prevent further tillage from being converted into pasturage, it met the fate of all such futile legislation.

Two or three herdsmen being employed where formerly two hundred yeomen found happiness and plenty in agriculture, it is not surprising that men were idle and hungry; that poverty made its appearance once more; that homeless wretches wandered in the highways ready to beg or to steal.

\section{The Struggle of the Estates.}

The narrowing of opportunities to the possession of land imposed by the feudal system produced a state of things, as decay set in, which resolved roughly into the Three Estates-the Crown, the Church and the Commons. The two first named gradually became competing monopolies as trusteeship became corrupted into ownership.

By the Statute of Merton, I235, the Crown and Church vassals were allowed to enclose at will any "waste" lands attached to manors. The thin edge of the wedge was finely pointed by the provision that the commons were left with "sufficient" pasture, and that means of access thereto were ensured. Considering that in the reign of Queen Annè three million acres of common lands were enclosed, and that in the first half of the nineteenth century six million acres more were added, which altogether is one-third of the whole cultivable surface of England and Wales, the Commons Estate, it is plain, was originally very great, probably greater than the other two Estates combined in area at the time of the Conquest. 
The survival of the commons was early imperilled by the primitive allodial conditions of tenure, and to that is fundamentally due the ease with which they were crumbled and assimilated by the predatory lords of the manor.

In order to escape feudal obligations to the crown, many crown tenants had alienated their land to the Church, receiving it back again as Church vassals. In I279 this was forbidden by the Statute of Mortmain, but in the meantime the Church had become a very rich and powerful ecclesiastical combine and "owned" about one-fourth of the most fertile land of England.

At various times before Henry VIII's reign the crown and Church land monopolies had devoured the best common lands, and then they proceeded to war upon each other.

\section{The Grown consumes the Church Estate.}

The Church and guild lands were tilled generously with plentiful labour, and much of the distress caused by the forced unemployment was ameliorated as labourers were absorbed by the monasteries and abbey lands. The Church grew richer upon wage slavery, but increased production from the Church lands had a lowering effect upon food prices, and incidentally saved the country from famine.

The greedy manipulator Henry VIII envied the wealth of the ecclesiastical vineyard, and many, seeing the luxury and display of the ambitious churchmen, ignorantly attributed the growing poverty in the country to their acquisition of riches. The king and his henchmen, therefore, taking advantage of the passions aroused by the so-called Reformation, proceeded to dissolve the monasteries and to confiscate the abbey lands. Many of the guild endowments were also taken in Edward VI's reign, but the London commoners saved those of the City.

Needless to say, these fertile lands were not resumed as a public domain ; they were given away to royal favourites, if not by Henry himself, at any rate pilfered during the reign of the baby king Edward VI.

The Duke of Somerset, protector of the young king, pitied the labourers turned out by the despoilers, and demanded by proclamation "that they who had enclosed any lands, accustomed to lie open, should under penalty 
before a day assigned lay them open again." The patriotic duke was indicted for high treason and beheaded.

\section{The Attempt to re-establish Chattel Slavery.}

As though they were themselves responsible entirely for their misfortunes, the unemployed were very harshly dealt with. During the reign of Henry VIII seventy-two thousand "great and petty thieves" were put to death, and there were sixty thousand prisoners for debt rotting in gaols throughout the land.

An Act was passed against idleness and vagabondry by a Parliament of landlords, which provided, "if any man or woman able to work shall refuse to labour and shall live idly for three days, he or she shall be branded with a red-hot iron on the breast with the letter V, and shall be adjudged for two years the slave of any person who shall inform against such idler."

Masters were empowered to feed their slaves on bread and water, to beat and chain them, to sell, bequeath or hire out, and to put a ring of iron about the neck, arm or leg for the more knowledge or better surety of keeping them. An escaped slave was to be branded on the cheek and become a slave for life. On a second escape he was "to suffer pains of death, as other felons ought to do." Such was the attempt made by a Protestant Government three hundred and seventy years ago to re-establish chattel slavery in England, and a few years later, in 1562, Hawkins began the English slave trade between Africa and America.

\section{Agrarian "Rebellions."}

The Pilgrimage of Grace in the North and agrarian AntiProtestant disturbances in the South were revolts in protest. Blind resentment is often discharged in "religious " bitterness and strife, neither side seeing the true common cause of their misfortunes.

At Norwich in 1549 Robert Kett, a landowner, supported by twenty thousand labourers, was the first "leveller" of the fences and ditches round the enclosures which had been made by the monopolists. This "rebellion" was finally repressed by means of the aid of German mercenaries. 
Kett and his brother were hanged in chains and ten thousand country people were put to death that year.

Gangs of "broken men" and "sturdy beggars" held whole tracts of country in terror. It became the sport of the profiteer gentry to capture and hang fifty of these outcasts at a time, and complaint was bitterly made to the Government of the needless delay in waiting until the assizes for trial.

Elizabeth's reign was marked by measures of palliation, such as poor law maintenance. It was directed by the queen that each labourer's cottage built should have assigned four acres of ground, in the penalty of "a fine of 40s. per month the cottage is so continued." The effect was similar to that experienced at the present day, when good intentioned legislators proceed to pave the earthly hell of manufactured "overpopulation."

As one might reasonably have expected, few cottages were built, and the housing question became a burning one. Labourers left the hostile country-side and crowded into the towns and cities for security, where they made rookeries and established slums on a large scale. Elizabeth thereupon proclaimed against the building of any new houses within three miles of the City of London and against "letting or setting any more families than one only to be placed in any one house."

\section{The apparently Miraculous Escape of the Landlords.}

Remembering by transmitted association their escape from the danger of ruinous feudal obligations, based upon the principle of "ability to pay," the vassals of the crown, attending, as they fancied, to their own preservation, had in general little real pity or sympathy for the evicted peasants. They were quick to notice how short-sighted the dispossessed were, and how ready the discontented mob were to blame each other.

Says Professor Thorold Rogers: "There is nothing in the history of civilisation more odious than the meanness of some English landlords, except it be their insolence. They have been abetted by the foolish farmers, who ground down their labourers, and have finally sacrificed themselves to the rent-rolls of profligates and gamblers." 
All the movements that have been made by mankind towards slavery have been made in the general belief that freedom, that is, the preservation of self and of others, was only to be obtained by the sacrifice of liberty. The landlords, who believe it is the liberty of others which should be sacrificed for their freedom, are a product of unregulated selfinterest. They are creatures of circumstances for which all are responsible.

The mental blindness of the labourer, blaming the farmer or the manufacturer for elbowing him out of natural rights, is as reprehensible as that of the farmer or manufacturer, who complains that he is squeezed on either side. The smaller profiteer in injustice is as anxious to prop up a system ruinous to himself as the greatest monopolist, because others seem worse off and his faith is weak. All attribute their misfortunes to the persons nearest to them, and refrain resentfully from questioning the superstition which puts all in duress.

In this fact of mental blindness lies the explanation for the apparently miraculous escape of the landlords and their sycophants. It was only apparent, however, because they did not escape the consequences, nor have they ceased to suffer.

Those living dangerously, knowingly or unknowingly, are conscious they are enveloped within surroundings possessing potential hostility. It was believed that the third generation of robbers died out, and so fearful were the landgrabbers of the vengeance of God that, in signing an agreement to enclose portions of the public domain, they signed in a circle in order that no man might appear to sign first!

\section{The Divine Right of the King becomes the Divine Right of the State.}

The fratricidal struggle of the Parliamentary Wars, in which so many monopolists, including Charles I, lost their lives, followed inevitably. Protector Cromwell, descendant of Henry VIII's chief instrument in the confiscation of the monastic lands, now abolished the military obligations of the crown tenants, which doubtful service was almost all that survived of the feudal conditions of land tenure. A standing army was introduced, supported by taxation upon 
articles of consumption, levied by a landlord Parliament. The landlords owned the State, and claimed divine right and passive obedience.

When Lieut.-Colonel John Lilburne, a leading "leveller," was sent to the Tower, and Gerrard Winstanley's " diggers" had been shot down by the New Army, Cromwell piously thanked God for a great deliverance. The divine rights of the people were trampled down by the joyless Puritan.

The public of the sham Commonwealth were beginning to be taught, by those who rob widows' houses and make a pretence of long prayers, that poverty was due to "overpopulation." Minister Moore of Leicestershire, in a pamphlet which he entitled The Crying Sin of England in not Caring for the Poor, exposed the hypocrisy of this hardy blasphemy.

He wrote: "How great a shame for a Gospel magistracy not to suppress make-beggars, in countries, cities and towns. I mean the unsociable, covetous, cruel brood of those wretches that by their enclosure do unpeople towns and uncorn fields. 'Alas! master,' says the beggar, who with his wife and children goes from door to door, 'we were forced out of such a town when it was enclosed, and since then have continued a generation of beggars.' The excuse given by the rich is that unless they enclose, the poor, like flies and lice, will eat them up. They usually, on enclosure, treble the price of their land, and this they get by flaying the skin off the poor."

The Commonwealth brought forth only sour grapes, and it was no wonder that, with their teeth on edge, the surfeited nation welcomed Charles II and indulged with that licentious cynic in an orgy of evil-living, until sobered by the Plague of 1665 .

\section{The Theft of the Immature Fruits of Liberty.}

Cromwell and the landed aristocracy feared the "levellers," who demanded "true and perfect freedom in all things," because it was seen that if they were successful the "corner" in land would be destroyed, and rents would fall from the height which users in their extreme necessity had to pay the landlords. Not only this, but a new variation in lucrative profiteering had been discovered, which before had not been so generally exploited in England. 
Besides the disappearance of bondmen and serfs as a result of the Black Death, there were other signs of slow progress which had surely taken place in the general wellbeing of the European nations. This progress was not unlike the improvement which takes place in the health and credence of a prisoner who has enjoyed a measure of freedom for some little time. Advancement in better methods had taken place in agriculture and in the fisheries; invention had been busy in textiles, and shipbuilding had greatly progressed. The trader, for whom there was little room in the feudal system, had been set free to some extent.

In these circumstances the people were now more desirable as slaves. It was the immature harvest of the fifteenthcentury liberty which the profiteers of the post-Reformation were impatient to reap for themselves. Greed frequently overstepped itself, and it was found, when slavery of the person was attempted, that owing to advance in credence such bondage was no longer possible.

Some new slavery had to be tried, the effect of which was beyond the understanding of the average worker. By a process of elimination wage slavery was arrived at, the people as a rule seeing no wrong in the buying and selling of land, upon which immoral principle wage slavery, or socalled capitalism, is founded.

\section{The Desirability of Thinking in Terms of Labour instead of in Terms of Money.}

In thinking of wages, rent and interest, it is desirable to forget about money, which is only an exchange medium, and avoid confusion of thought by thinking in terms of labour.

All wealth being the product of labour applied to natural resources, included in the comprehensive term "land," it follows of necessity that all who labour by extracting raw materials from the earth, converting them into new forms by manufacture, transporting them to where they are wanted, warehousing, recording, superintending, managing, or in any way serving themselves and others as chemists, engineers, doctors and so forth, by mutual free exchange should be wealthy. It also follows that none should be poor save the wilfully idle and wasteful, because the most extensive 
needs of man and his dependents cannot in the nature of things outrun the limitless means of their environment.

But a different state of affairs arises when it is superstitiously believed that certain "idle" people, qua landlords, own the earth, and in virtue of this assumption are allowed to demand from those who labour a contribution of their labour as rent for permission to live upon the planet.

So long as the "idler" can be entrusted to permit rents to assess automatically by free competition for territory among would-be users of land, a modicum of harm may result, because the collection of the economic rent tends to equalise opportunity and preserve just relations. But experience shows that landlords, claiming "divine right" or dominium, are not disinterested agents, and therefore cannot be trusted, either as private individuals or in the form of an oligarchy affecting to control the "freedom of the earth" for the public good by selecting its tenants.

In every case, since it is to the special interests of the "idlers" to divert to themselves as large a proportion of other people's labour as they can, it is found that land is always withheld from use in order to intensify competition for the land permitted by the "controllers" to be used. In this way the idle "controllers" extort a monopoly contribution of labour as toll from users struggling with each other for existence.

It is clear that from this original profiteering many forms of intermediate monopolies may extend, growing into monstrous shapes, tending to overshadow and obscure the root injustice from which they really spring.

\section{The Philosophy of Ownership.}

It is an everyday application of the Golden Rule that the producer of wealth has the premier title of use to what he produces. Our own rights in this regard are respected when we respect the rights of others to determine how they shall devote the proceeds of their labour, to consume the product themselves, and/or to exchange it for the premier use of the wealth of a different sort produced by others.

Capital is a portion of the wealth produced and put aside by the labourer in tools, buildings, stock, seeds and other commodities used for the production of further wealth. 
Obviously, it is absurd to say that "Capital employs labour," because labour employs capital in the correct sense. Also it is nonsense to speak of the physical strength of the manual labourer as his "capital," and similarly of the mind of the scientist or the voice of a singer as his " capital." These errors of thought are survivals of an age when men and women were regarded as "capital."

It is equally wrong to say that land, which is not a labour product, is capital. Capital, unlike land and labour, is not a necessary factor in the production of wealth. It forms only a small proportion of the total wealth which man, assisted within Nature, produces.

Since the whole includes the part, it follows that capital belongs of right to the labourer producing it, to use it himself or to exchange any surplus of one kind with that of a fellow-labourer who possesses a surplus of another kind, of which the former is in need. The labourer may also freely co-operate with one or many other labourers, using the combined capital of all in partnership.

Some forms of wealth laid aside as capital, as, for example, timber, preserved fruit and wine, improve with age up to a certain limit before deterioration sets in. Other forms, like fruit trees and farm stock, tended by human labour, come to maturity slowly, then seed and multiply after their kind before returning to the earth. Such increase or interest is deferred wages and due to the labourer tending and maintaining the capital.

All wealth in process of time, and no matter how permanent it may appear, decays and returns to the earth from whence it came. In absolute fact, therefore, we own nothing and only possess rights in usufruct. That part of wealth which for convenience is called capital also depreciates and crumbles away. It has to be continually maintained and renewed by the application of human labour, performed by individuals singly or in partnership.

Capital of the non-reproductive type is endowed with interest-bearing, while it is being used, in virtue of the exchange continually going on between it and different forms of improving and reproductive capital. This interest also belongs to the labourer using the capital, because it is part of his wages. Free exchange provides for all cases where 


\section{THE SLAVERY OF MONOPOLIES}

labourers possessing varying shares are in fellowship as regards interest and depreciation of capital.

Those who talk of abolishing interest are thinking only of necessitous usury upon loaned money or commodities, which is not interest, but is the tribute paid to an adventitious monopoly battening upon wage slavery. Natural or economic interest cannot be abolished any more than depreciation of capital can be stayed. The fruit grower who plants fruit trees and sells the fruit and the peasant who keeps cows and sells the dairy produce receive interest upon every transaction.

The principle of capital is similar to the principle of population. If assimilation exceeds dissimilation, that portion of wealth put to the purpose of capital increases, and, vice versa, if dissimilation exceeds assimilation the fund of capital decreases in quantity. Political economy is more nearly allied to biology than to physics.

It is evident that in free production and exchange such forms of capital increase for which there is scope, that is, where in freedom labour for the time being obtains the better reward in wages, including interest. With production and exchange free in voluntary co-operation there would of necessity always be a natural tendency towards a just and symmetrical distribution of wealth, and consequently of capital and interest.

\section{The Constitution of the Modern Capitalistic System.}

Just as in an enclosed space it is rendered increasingly difficult to conform to the rule of the road as the space is narrowed or becomes overcrowded, so in the economic enclosure, created by the tightening process of land monopoly, it becomes increasingly difficult to observe the Golden Rule, upon the observance of which our preservation depends.

Property rights and titles being thus deranged by false philosophy, the larger number of wealth producers, for the reasons already stated, do not receive the equivalent return for their services as wages. They cannot, therefore, put aside as capital much of the wealth which falls to them, and become capitalists.

Of the difference between the wages of slavery or minimum wages and what should have been their share, much is 
passed on by the overseers to the lords of the enclosure, who are consumers only, and who get a greater share of labour products according as they can restrict the production of total wealth. A similar quantity of labour products is consumed ostensibly, and partly, for the benefit of the whole community by a costly expert controlling bureaucracy or Government, the individuals of which are paid for their services accordingly. The remainder of the difference is retained by the aforementioned industrial overseers, who are wealth producers themselves. This latter portion is "the diminishing returns" of the system, because the monopolists, including the Government, take greater and greater shares.

It is these three classes, loosely called capitalists, from whom in the present abnormal circumstances wealth in the main is laid aside as capital, to be used as a tool by the wealth producers in the production of further wealth.

But because the system is founded upon iniquity, the modern capitalistic system is a diseased and waterlogged growth. What the capitalists call their capital is largely fictitious value, because things are called capital which are not capital or else have no existence except as debt.

\section{The Rise of the Farmer Capitalists.}

If the landlords cannot be judged for what others would have done in their place, and for what Professor Rogers calls " meanness" and "insolence," still less can the tenant farmer of the seventeenth century be censured for taking advantage of the reservoir of the unemployed made by forced migrations from the enclosed commons and the subjugation of the Ecclesiastical Estate. In self-interest they were wise in their generation, and benefited others while benefiting themselves.

To the example of the Dutch farmer capitalists we owe in England the introduction of continuous crops in place of barren fallows and the discovery of true rotation. It was they who initiated the methods which improved the quality of domestic cattle and sheep and increased their size so enormously.

The success of the Hollanders in this, and in navigation and commercial enterprise, aroused the emulation of enterprising Englishmen and the envy of the snobbish land 
monopolists, who boast that they do not soil their hands in anything so mean as trade. These latter quarrelled with the House of Orange at the time of the Commonwealth, irritated because the Dutch, tolerant in all things, gave sanctuary to Charles Stuart, who later as Charles II, at the Restoration, characteristically repaid his benefactors by an attempt to ruin them.

But in James II's reign a truce was negotiated, and in the subsequent peaceful intercourse the improvements made by the Dutch in shipping and agriculture were largely adopted in England. A transient period of prosperity for capitalistic farming followed.

\section{The Decline of the Farmer Capitalists.}

The chequered career of the agricultural industry between this period and the nineteenth century is a miserable history of parasitism.

Whereas in I500 a week's wages would keep an agricultural labourer's family for a month, in I6oo the purchasing power of the labourer's wages was only half, and would only keep the family for fourteen days. But the farmer was not for long allowed to retain the plunder, because the landlord continually raised the rent and absorbed what the Government did not take in rates and taxes.

It was this experience, repeated many times, which taught the farmer to avoid progressive methods and seek protection in poverty-stricken appearances. Instead of increasing production, he took the line of least resistance. With their backs to the precipice of unemployment, the farm labourers had to accept less wages, until in I760 the week's wages would only keep the family for nine days.

Successful in their ca' canny policy, farmers in the eighteenth century were paying less than the economic rent. They could also no longer disguise the fact that they were restricting output. They refused to take advantage of the reforms in stockbreeding and in the cultivation of cereals and special grasses like clover, which enrich the soil and are good for hay.

It was necessary to speed up production, and in $I 772$ a great agitation was set on foot to make agriculture a fashionahle hobby for the "landed interests." Arthur 
Young, who travelled all over the country, vehemently urged landowners to raise rents, in order to force tenants to use improved methods of culture so as to get better yields. Once awakened, the parasitic " interests" duly resumed operations upon their unfortunate hosts.

There is some reason to believe that this policy had some effect in stimulating better farming, but, taking into consideration the discouragements given to cultivators in the past, it is not surprising that some farmers persisted in attempting to make a precarious livelihood by inefficiently cultivating large areas, employing little labour at the lowest wages possible.

The farmer was not exceptionally ignorant because he believed it to be a calamity when harvests were remarkably good and prices were so low that he found it difficult to pay the rent and get a fair return for himself after paying rates and taxes. Nor, on the other hand, could he be held to be specially callous that when harvests were very poor he was as elated as a farmer can be, and did not notice that the industrial wage slaves and their children were hungry because they could not buy bread, made artificially dear by the profiteers taking advantage of the shortage.

The "landed interests" and the farmers considered that the country was prosperous when bread was dear and rents were paid freely. It is for this reason that they show such hostility to the small-holders, who farm intensively, and that they object to town-dwellers possessing allotments. It is also for this reason that landlord Parliaments imposed "protective" duties upon food, and sought to perpetuate starvation, high rents and high prices.

The agricultural labourer got no advantage from these manipulations. His wages were soon insufficient for the subsistence of his family, owing to the high prices, and the benevolent monopolists found it necessary to subsidise wages at the expense of the taxpayer. Poor Law relief was given proportionately to the price of bread and the size of the family. Many wretched farmers then further reduced wages paid to their helots, so that they were enabled to claim more relief from the parish, just as at the moment many employers are taking advantage of the returned soldiers' pensions.

The landlord only in appearance contributes to the 
burdens of taxation. All rates and taxes, direct or indirect, are taken in the last resource in labour products from wealth producers, or in services performed by labour of "hand and brain." The landlord qua landlord, not being a wealth producer but a much consuming "idler," does not himself pay taxes, but acts in the capacity of tax-collector from those who are industrious.

Although in mediæval Europe the bailiffs for the great agricultural crown and Church tenants kept excellent accounts, and were adepts at bookkeeping, it was taught in the enlightened nineteenth century that it was impossible for farmers to keep accounts, and therefore they could not know what their income was. When the income tax was imposed, the farmer was taxed at a fraction of the ordinary rate upon a nominal assessment based upon the rent he paid to the landlord.

But neither in the case of the parish doles to augment wages nor in the favourable treatment as regards income tax was the farmer for long able to benefit. In his capacity as the "owner" and monopolist of the enclosure, the landlord was able to make the overseer of the wage slaves disgorge the plunder in higher tribute by withholding the land from use except at his own terms. If the farmer offered opposition he was evicted and his improvements were confiscated by the land profiteer, who let the land to an incoming tenant at the highest rent he could obtain.

\section{The Disaster to the Capitalist Farmer.}

A great disaster befell the capitalist farmer. He was paying an uneconomic speculative rent, based upon the artificially high price of corn, bolstered up by the import protective duties. The evil was unseen in its real malignity until the abundant harvests of 1835 and 1836 .

Profiteering being impossible in the midst of profusion, the farmers had to sell at a natural price, while they were expected to pay an inflated rent. But the consequences did not end there.

The wage slaves throughout the country, after satisfying their usual humble needs in the three great requisites of food, shelter and raiment, found that, owing to the low price of food, they had means beyond this minimum, represented by 
a few shillings a week. This they spent in determining labour to the production of utensils, of which they were sadly short.

It was an illustration showing the interdependence of the members of society one upon the other, and it showed that what was a real benefit to the community in general was reflected in the general better health and prosperity. The slightly better distribution of wealth to the extent of a few shillings a week among the millions of those who produce the wealth, stimulated further wealth production. All other industries bad a short run of comparative prosperity because the market demand had been widened.

The experience made men think, and a great agitation uprose, led by Cobden and Bright. Instead of the vague harangues of noisy and designing demagogues, there was a sober consideration of facts, and conviction bore fruit. The Corn Laws were abolished in deference to public opinion by a Government of " landed interests," impelled to act justly because the eyes of the nation were momentarily opened. 


\section{BOOK III}

\section{FROM THE OLD TO THE NEW WORLD}

\section{GHAPTER XV}

\section{USURY AND THE GREAT BUBBLE}

\section{READER'S GUIDE}

Is Chapter XV we deal with Currency and Exchange, and we attempt to explain how the individuals of a community get into debt with each other, so that society stratifies into moneylenders and creditors. This hardening into castes is due to the impossibility of redemption while the masses remain within the prison of land monopoly.

\section{The Headings are :}

The Currency-International Trading-The Advantages of the Rich Home Market-The Evils of Wealth Concentration-The Inflation of Land Value-Investment and Speculation-The Recurrent Financial PanicsThe National Debt-Foreign Loans-War EconomicsThe Cost of the War came out of Contemporaneous Production-How the Base of Vested Interest was broadened -The Prosperity of the War-The Post-war Stagnation -The Shortage of Raw Materials-The " Blessed " Debt and High Prices-Producers and Consumers-All Taxation is paid by Industry-The Way to Real Prosperity and Happiness. 
Care for us! True, indeed! They ne'er cared for us yet; suffer us to famish, and their storehouses crammed with grain ; make edicts for usury, to support usurers ; repeal daily any wholesome Act established against the rich; and provide more piercing statutes daily, to chain up and restrain the poor. If the wars eat us not up, they will; and there's all the love they bear us.-Coriolanus, Act I, Scene I. 


\section{USURY AND THE GREAT BUBBLE}

\section{The Currency.}

Money, in the form of minted coins or printed notes, when handed by one person to another in trading, is a promise to pay either directly or through intermediaries certain labour products or services in exchange for other labour products or services. The system of common money or currency guaranteed by the community is comparable with the endless belt or chain which is used over and over again in the conveyance of energy or material from one machine to another.

Cheques, handed by one person to another, record promises to pay, and are in the nature of private money, the bank only acting as a clearing or balancing house for transactions as between individuals.

It is evident that while coins or tokens of metal are convenient because of their hard-wearing properties and general handiness in small transactions, all records of promises to pay could otherwise be in writing or in printed notes. In the case of printed notes in common circulation, they amount in effect and in the sum total to a promise to pay on the part of the whole community labour products or services to itself.

In an ordered state of society the currency at any time would naturally be "backed" by the economic rent of land, but when the community do not possess their natural revenue, they are at the mercy of those who profess to govern them, and the common currency may be debased by governmental forgery. In the reigns of Henry VIII and Edward VI of England, this was done upon a large scale and while much more injury has been attributed to the forgery than can be justified, much real distress was occasioned by it, due to loss of confidence and the necessity of 


\section{FROM THE OLD TO THE NEW WORLD}

having to revert to direct barter. This disability is magnified many times in the case of international exchange.

In the absence of the natural " backing " for the common currency, endeavour is made to give confidence to traders by arranging that the intrinsic value of the coin shall be equal to its exchange value as a commodity; hence the socalled "gold standard," in which the sovereign is equal to a sovereign's worth of gold. Notes printed by the Treasury in circulation are then piously believed to be "backed" by an equivalent value of gold hidden away in the bank. We are thus presented with the curious anomaly of labour expended in digging gold from one hole in the earth, only to tuck it away again in another hole to be a temptation to imperial thieves.

Even were the exchange value of gold the best basis for a currency unit, public Treasury notes in circulation need not be "backed" by an equivalent value of gold stored in bank vaults. No such backing is required in modern times for the private notes and bills in circulation, the flow of which at any time is greater than the stream of public money. In practice, one piece of gold is enough as a master measure for the sovereign, the dollar or the mark, in the same way that the yard or the metre is standardised.

Just as we possess units of length, weight and electricity which remain constant, so if we are to avoid confusion in commerce it is essential that we have a unit of currency which cannot be tampered with in an arbitrary manner, and so become a means of indirect taxation and a counter for disastrous gambling. So long as the public acquiesce in the immoral practice of Government forgery by which Treasury notes are printed and issued as promises to pay for services there is no intention to redeem in a regular manner, then confusion and want of confidence will continue in commercial dealings, whether the exchange takes place within the State or with neighbours in other lands.

But gold itself as a commodity varies in value from day to day. Think of the demoralisation in industry if, instead of the measure of length remaining at all times constant, it varied even a small percentage from time to time!

In the nature of things, the sum of the population divided into the total economic rent of a country gives a quotient 
which represents a unit value in labour services that is more constant than any currency unit based upon wheat, gold, silver, or any other commodity. Within the ordered State built upon economic justice the public servants of the commonwealth would be authorised by the people to pay in Treasury notes (which would be in fractions and multiplies of the unit defined above) for communal services up to an amount equal to the economic rent for the whole land of the country for the financial year.

These notes would be legal tender for the payment of any amount, and form the basis of private promises to pay by cheque. Debasement of the currency by inflation would be avoided by keeping in circulation notes to a definite quantity, as, for example, the value of one year's rent-roll, and this could be accomplished conveniently, in conjunction with the banks, by the tender of Treasury notes by landholders in payment of rent to the community, the notes returned being cancelled by the revenue department as received, new notes being issued as payment for common services to replace the old ones.

In all transactions between individuals the real security is the promise to pay, and the promise is fulfilled as a practical manifestation of the natural Law of Equity, not because certain pains and penalties have been invented by man in a vain attempt to correct the obliquity caused by social maladjustments.

Those who disregard their promise in defiance of the Golden Rule suffer the consequences by loss of credit. No penalty is more effective than that others should refuse to co-operate with a defaulter in the exchange of their services for his. Even in society, constituted as it is, it is rarely that in business recourse is made to "law," or that satisfaction is ever obtained by going to "law."

\section{International Trading.}

In modern international commerce no money passes, and accounts are balanced by means of Bills of Exchange. As a simple example we may suppose Smith of England has purchased $f_{\text {roo }}$ worth of goods from Morgan of America, while at the same time Robinson of America has purchased an equivalent value of goods from Jones of England. It is 


\section{FROM THE OLD TO THE NEW WORLD}

clear that if, in settlement, Smith of England pays $£$ Ioo to Jones, and Robinson of America pays an equivalent amount to his fellow-countryman Morgan in dollars, all accounts have been squared.

Through the agency of the banks in the respective countries the most complicated transactions are rendered easy by means of bills of exchange, which are tendered like ordinary money. International indebtedness being cancelled by domestic indebtedness, goods pay for goods.

There is no essential difference between domestic and international trading, which is carried on for the convenience, gratification and profit of all taking part. All legitimate exchange tends to the promotion of peaceable and friendly relations, and international trading, far from harming domestic industry, enlarges and enriches it.

The periods of harvests vary in each country, and exchange of produce is neighbourly and advantageous. Each country has natural advantages not enjoyed by another, which enable the labourer living in the favoured country to produce certain goods with less effort than in another country. In some country an advance in applied science may have been made in a certain direction, whilst a different kind of advance in knowledge may have been made in another. In exchange the two countries get the benefit of the combined advantages.

Let us assume that for an effort represented by 50 some commodity is produced in America which in England would require an effort represented by Ioo, and that for some other product made in England an effort represented by 50 is required as compared with 100 in America. Then by exchanging advantageously, as they would naturally, each country gains in the proportion of 150 to 100 .

Many of the imports are intended to be used as tools in the production of further wealth, and the advantages of purchasing, say, a machine tool for a workshop of higher efficiency from abroad as regards future rate of production tremendously outweighs any narrow consideration of its higher first cost, or, on the other hand, the encouragement given to some home machine-tool maker to produce an inferior article when he should be impelled to improve his product.

Gold is an exchangeable commodity like other things, 
and it is fallacious to believe that it, or any other commodity, has some virtue peculiar to itself which renders it more desirable as a commodity than other commodities. If the goods obtained in exchange for gold were not more highly esteemed than the gold, they would not be purchased at the price agreed.

\section{The Advantages of the Rich Home Market.}

It seems incredible, to those who mistake petrifaction for evidence of progress, or who think of wealth in terms of money instead of labour products and services, that the accidental better distribution of purchasing power, when the Corn Laws were rendered inoperative, should have such a freeing effect upon industry generally. They cannot see why the power of purchase concentrated in fewer hands should not resolve into a similar effect in the long run.

This mental difficulty is due to it being forgotten how vitally important to humanity is the way in which the purchasing power is expended. For example, it was estimated that in 1835 and 1836 the difference between the natural and the artificial or profiteering price of corn made a difference to the labourer's family of about 4s. per week, and that, say, four million families were thus affected in the British Isles.

These small increments in the aggregate amounted to about forty million pounds of more equitable wealth distributed per annum, and as the possessors purchased not land nor Government bonds, nor did they speculate in stocks and shares, but instead bought manufactured articles, industrial life began to throb with activity because it was freed temporarily.

The subsequent abolition of the Corn Laws gave a further breathing period lasting for some years, and allowed Britain as a manufacturing country to advance in front of other countries. British manufacturers established themselves upon an adventitious monopoly which exists no longer, and the curse of wage slavery is being fulfilled for them as for the farmers.

It is now being lost sight of that a wide, rich home market is more valuable than a scattered trade among barbarians in images, beads, cheap cottons and bad rum, exchanged for palm oil, gold dust and copra, desirable though the latter may be. The external trading of a country is very 


\section{FROM THE OLD TO THE NEW WORID}

important, but at all times it should be remembered that it is a fraction of the internal trading.

So far as Great Britain is concerned, its vaunted external trade has been done largely at the sacrifice of security in the matter of food production.

\section{The Evils of Wealth Concentration.}

The action of land monopoly, in causing purchasing power to be concentrated in few hands, has the effect of inducing a traffic in that which is not property. There is the whiteslave traffic, and along with speculation in land there is the progressive watering down of joint-stock companies. There is also the collective slave market, in which is bought and sold the capacity of the community to pay taxes or tribute in the future, commonly known as the National Debt.

Industry, whose feet are shackled by land monopoly, is expected at the same time to provide services and labour products as rent and interest to landlords and bondlords. So long as land monopoly remains, the labourer of hand and brain has no hope of recovering his freedom by paying back the principal of the debt. It is not intended by the landed gentry and the so-called capitalists, who put interest before principle, that he shall.

Just as so great a portion of human effort is unemployed or wasted in immoral directions, so, owing to purchasing power being concentrated in few hands, wealth put aside as capital is not employed to the fullest advantage or it is wasted in works of vanity.

\section{The Inflation of Land Value.}

If property rights were justly recognised and the labourer not stripped of the reward of his labour, then in self-interest he would only create that which is good. The wealth put aside as capital would consequently be directed to the further production of Goods instead of Ills for Humanity.

But when so-called capitalists, profiting by wage slavery, become possessed of great purchasing power, self-interest for them is directed to the acquisition of greater power in the struggle to escape the morass of poverty which surrounds, and which steadily creeps in upon them. That is to say, self-interest is directed to the welfare of Property before Humanity. 
The capitalists themselves cannot, in the satisfaction of their legitimate desires, consume all the purchasing power which the "vested ignorance" of the masses enables them to acquire. That is impossible, owing to the narrowing of opportunities by "the landed interests," which restricts demand. There is therefore a surplus of capital which cannot be employed in production, and it may be said to compete for employment with that which is employed, whether it be employed in good or ill directions.

The rent of land, which cannot be abolished, must either be taken by the community to whom it belongs or it will find its way into private hands. So long therefore as land is held to be private property, there will always be great competition for the acquisition of so permanent and certain an "investment." High prices are paid consequently by capitalists not only for the intrinsic value of the rent, but also for the expectation of future increase and the social power landownership is supposed to confer.

That is why, in the speculative inflation of the cost of land far beyond its economic level, the return upon money so "invested" frequently does not exceed 2 per cent. It is for this reason that wealthy capitalists, accustomed to get a good return for their investments, administer a recently purchased estate with far greater rigour than their more aristocratic predecessor, who was deterred by personal considerations from raising rents of tenants to the highest point possible.

\section{Investment and Speculation.}

The capitalist who lends purchasing power to some promoter of a new or extended enterprise is doing something which is generally of real benefit to the community. The investment may provide tools for the increase of wealth and employment. It may provide the consumer with some useful commodity and fill a long-felt need.

There is a great difference in utility between this action and the action of the capitalist who becomes a landed proprietor, or who assists a promoter to form a trust amalgamation or otherwise attempts to make a "corner." The latter is calculated to decrease the production of wealth and lessen employment ; and the effect of the trust in restricting output 


\section{FROM THE OLD TO THE NEW WORLD}

to raise prices is that the consumer is enslaved to the monopoly by the private tax of the profiteer.

The success of any commercial undertaking, useful or otherwise, may lead to excess and disaster in the competition for shares on the stock exchanges by those who hold more purchasing power than they can find useful employment for. It is, however, in those undertakings which are of the nature of monopolies, such as the circulatory systems enjoying legislative protection, combinations of financial interests and "vertical" trusts, that the greatest gambling takes place.

The South Sea Company is an example of a trading monopoly given certain governmental " concessions," which illustrates, in its rise and fall, how the greedy capitalists are plundered by operators with "inside knowledge." When the stock of the Company mounted from $£$ 100 to $£ 2,000$, it was not that the actual value of the stock had become twenty times what it was originally, but only that the promoters, who had sold out at the higher figure, determined to themselves labour products or services twenty times what they subscribed.

The railway mania in I844-5 outdid even the South Sea Bubble in the mad scramble which took place for stock. Scandals of all sorts surrounded the promotion of the railways in Great Britain and elsewhere. Useful canals were purchased by the companies and almost entirely put out of commission to prevent their competing with the railways, so that the fares and freights extorted from travellers and traders would pay "interest " upon money expended in this irregular fashion.

Extortionate sums were paid to landlords for land, frequently swampy and derelict, and much railway stock, for this reason among others, has never paid a dividend, in spite of the monstrous charges made for the conveyance of passengers and merchandise. The overcapitalised railway companies have been notoriously unprogressive and inefficient. Similarly, the telegraph, telephone, gas, water and power supply companies have been waterlogged and hampered by the improper use of capital in legal charges and in purchasing way-leaves from landlords.

Yet it is in such diluted capital investments that gambling counters are chosen frequently by idle purchasing power. 
Cunning "bulls" and "bears" with " community of interest," by means of judiciously spread rumours in the newspapers and elsewhere, influence the "outside public," whose buying exalts prices of "securities" to dizzy heights, or whose panic-stricken selling deflates them to the depths. In the process the madding crowd of speculators are plundered by the operators, because they usually buy towards the top of the price and sell at the bottom.

It is told of Jay Gould that upon one occasion, being asked for advice in investing some money by the pastor of a fashionable New York church, he whispered a recommendation of Pacific Mails, and at the same time offered to reimburse the reverend speculator if his purchases of this favourite gambling counter should result in disappointment. When the pastor came to Gould later, having suffered heavy loss on the transaction, the financial expert handed over a cheque to cover the loss. "But how about my parishioners ?" bewailed the poor man. "You placed no ban of secrecy upon me, and their losses are enormous." To this Gould merely replied, "Yes; they were the people I was after."

\section{The Recurrent Financial Panics.}

It would be wrong to conclude that the smaller rises and falls in stock-exchange securities and the greater financial panics which recur every few years were entirely or mainly caused by the "pools" of operators. These, like the blind political operators forming a Government and supposed to lead or drive the blind multitude, merely try to advantage themselves, without any real intention to harm their fellows, who act simply in conformity with a social maladjustment.

In the case of the smaller movements, an edifice of fictitious value in some security is built up, similar to the driven snow upon the mountain-side, and its resting-place may or may not be indicated by the example of a "community of interest." It builds ever higher and higher, due to speculative buying, and the accumulation may be started down the slope of exchangeable values like an avalanche by a slight disturbance of selling by the "pool," which becomes itself sometimes overwhelmed in the disaster brought about by the gamble.

In the case of the larger movements, speculation going 
on concurrently in land, which is not wealth, but the source of all wealth, there is caused restriction in the production of real wealth due to narrowing of opportunities. The base of industry, upon which speculation rests, is thus gradually undermined, and becomes smaller and smaller in inverse proportion to the growing superstructure of gambling.

Borrowing and counter-borrowing take place. "Options" are purchased, loaned purchasing power is risked in " margins," and the unstable structure topples and at length collapses. Banks close their doors, thousands are ruined in bankruptcy, and the consequent dislocation of trading impoverishes others by unemployment over long spells.

Recurrent financial panics, which are caused by speculation, especially in land, are very similar in miniature to the collapses of civilisations which have taken place over longer cyclical periods of the historical epoch.

\section{The National Debt.}

After the Restoration, Parliament having divested the King of the power of raising taxes, the royal spendthrift was forced to agree to very onerous terms for money lent to him. It is written, " King Charles the Second being in want of money, these goldsmith bankers took Io per cent. of him barefacedly and by private contracts. On many bills, orders, tallies and debts of that king they got 20, sometimes 30 per cent., to the great dishonour of the Government." The King, receiving no support from Parliament, was unable to repay. His repudiation ruined many people who had lent their money through the goldsmiths, and the bankrupt finally escaped the consequences of this and other immoral actions by premature dissolution.

That which was deemed dishonourable in Charles came to be regarded honourable in Parliamentary Government. Subsequent rulers wisely conformed to the Constitution, and while they continued to speak of " my people, my army and my navy," took care not to speak of "my debt." The advent of the new sham democracy, and the substitution of the divine right of the State for the divine right of the King, was signalised by a delicate compliment to the hollowed majesty of the people, and the State debt was named the "National Debt"! 
The lesson of the South Sea Bubble drew the attention of the governmental operators to the greater possibilities of cheap purchasing power in the hands of those profiting precariously in wage slavery, and the National Debt, secured upon the tax-paying capacity of the nation, formed an apparently safe depository for moneylending capitalists seeking an alternative to the traffic in land.

Landlords for a time declaimed against the " new-fangled " finance, which competed with their monopoly, but even they succumbed in time to the attractions of the "blessed" Debt, which flourished exceedingly above the general misery of the poor, who were taught in the schools that no country could ever become great without its beneficent debt.

The captives of superstition, warring in the prison of land monopoly, thus compelled themselves to forge the golden bonds of usury, which grew stronger every succeeding generation. Read the following recent (I9I9) official advertisement, putting forward its advantages in the face of a falling revenue :

"To buy the Funding Loan is to create an estate. The Family or Trust or Business which puts $£$ Io,000 into this security and holds it continuously until 1960 will by that time have received no less than $£^{20,000}$ in interest alone. Even if the State then exercises its rights to redeem the loan at the earliest possible date, viz. in I960, a further sum of $£^{\mathrm{I} 2,500}$ will have to be paid for every $£$ Io,000 originally invested, making a total return of $£ 32,500$ for every $£$ I0,000 invested in Funding Loan now."

\section{Foreign Loans.}

The indigenous debt did not absorb all the unemployed purchasing power concentrated in the hands of the capitalists, and so, besides promoting loans to their own political monopolies called Governments, the super-capitalists, like the Barings and Rothschilds and J. P. Morgan, have also negotiated loans to foreign Governments struggling to establish power and might.

There is a great difference in utility between loans of this nature and money invested as capital in providing agricultural implements, seeds, and buildings for industrial enterprise in a new country, which, employed by labourers of head and hand, increases the wealth of nations. 
Foreign loans to Governments, to be expended in building warships and other slaughtering devices for the purpose of oppressing and taxing their nationals, discourage the production of goods and cause the unemployment of labour and capital.

Struggling egoisms, like South American Republics and the Balkan States, are forced to agree to high rates of usury because of uncertain revenue. A loan may be offered for subscription to the European public at roo by the issuing house of super-moneylenders, who only hand over 75 per cent., the remaining 25 per cent. being devoted to expenses and commission. After the negotiators and officials of the debtor country have handled it, the purposes for which the loan was originally subscribed probably do not get allocated more than 50 per cent.

"Interest" may have been agreed at the rate of 6 per cent., but by this means the tribute from the industry of the impecunious State or municipality becomes in reality I2 per cent., plus the cost of collecting the plunder. After a year or two the demands of the moneylenders may not be met, or the nation in its economic prison may lapse into anarchy, caused by the exaltation of prices rendered necessary owing to heavy taxation.

Such failures have sometimes brought about intervention by the armed forces of the moneylender countries at the expense and to the danger of their citizens, most of whom have no interest in such a sordid undertaking. It was this consideration which was at the root of the disastrous French and British intervention of I9I8-I9 in favour of the infamous reactionaries of Russia, Koltchak and Denikin, who were trying to set up another Tsarist absolutism.

The system of foreign loans is the more modern method by which one State becomes tributary to another, and "capitalist" Governments, in the name of their peoples, have acquired the "protectorate" habit, employing great robbers of finance for their purposes. It has been suggested by certain good-intentioned people that the League of Nations should acquire power in this way and become an international moneylender. Such policies are well calculated to create situations favourable to the perpetuation of warfare between members of the League, just as civil strife is stimulated by high taxation. 


\section{War Economics.}

That mere employment, arduous or otherwise, is not in itself a blessing has been well exemplified by the Great War of Europe, in which millions of people have been, for nearly five years, busily killing each other without regard for sex or age. Nevertheless, a lesson has been provided for those with eyes to see and the use of their understanding.

The proved capacity of the belligerent populations to produce an almost limitless amount of Ills, is evidence that in different circumstances they might have been Goods to an equal extent.

The determination of labour to the immediate establishment and maintenance of huge armies and navies, supplied with guns, projectiles, bombs, mines and poison gas for the business of destroying humanity, could equally well have been expended in the production of food, clothing, houses and other necessities and luxuries for the preservation and happiness of mankind.

Such a consideration made people wonder during the Great War why poverty existed before, and why it should continue.

If, for example, it is possible for Great Britain to keep and supply with munitions seven millions of war establishment, while hundreds of thousands of the population were engaged in " work of national importance," and at the same time also fed, clothed and more or less adequately sheltered, there is no natural impediment to the provision of all the necessities of peaceable life upon the most generous scale when all, including the armies of " no occupation," are engaged in wealth production-and this without struggle and long hours of daily toil.

But is this possible, when a very small number are superstitiously believed to own the source of all wealth, not only the surface, but also above the surface and down to the centre of the earth, endowed with power, by reason of this superstition, to allow the remainder to exist only upon the profiteering terms of monopolists?

\section{The Cost of the War came out of Contemporaneous Production.}

The accumulated wealth of the country, which comprised houses, railways, engines and ships, and so forth, in the 


\section{FROM THE OLD TO THE NEW WORLD}

possession of individual citizens, was used up to some slight extent, while the pre-war " preparedness " was used up almost entirely, during the progress of the war. But no reasonable person imagines that the huge running costs of creating and maintaining the land, sea and air services upon the war basis came out of past accumulated wealth, or that they could come out of future production by means of any feat of jugglery.

The cost of the war came mainly out of contemporaneous production in labour of hand and head, and the raw materials upon which labour was applied were taken from the earth mainly during the war period. Whence, then, comes the debt?

Instead of imposing taxation upon the same basis as the Military "Compulsion" Acts, and establishing at the same time Compulsory Civil Service, the latter was only applied to a limited extent in the case of industrial workers, and most of the purchasing power was lent, instead of being compelled from the war profiteers, among others. Landlords, for whose land the defence was made, and those who profited upon the wage slavery created upon the private ownership of land, thus obtained Government bonds, which were designed to command wealth as others produced it, not only for themselves during their lifetime, but also for their descendants, in the guise of "interest."

\section{How the Base of Vested Interest was broadened.}

The invading Germans in Belgium found a screen of widows and orphans a protection against the brave defenders, and the solicitude for the small moneylender ${ }^{\mathrm{I}}$ was intended as much to popularise the debt, and thereby screen the large bondlords, as to collect the comparatively small purchase power of the million.

The boasting which precedes borrowing was well illustrated in the pushing advertisements of "Victory" and "Joy Loans" after the Armistice, but it was not so startling as when the captives, "fighting for freedom," were invited to load themselves with "Liberty Bonds"!

\section{The Prosperity of the War.}

The prosperity of the Great War was not all fictitious. Owing to the temporary, almost complete cessation of I War Savings Certificates were free of income tax. 
unemployment real wages increased, and a better distribution of wealth took place, with surprising effect upon the general welfare of the nation. The comparative prosperity and attendant increased circulation of money could have been produced, however, without the accompaniment of killing, if, believing it to be urgently necessary for the preservation of the nation, some special combined effort of sufficient magnitude had been undertaken in almost any direction or directions.

Instead of shells and poison gas, snowballs and ozone might have been manufactured upon an immense scale. Instead of ironclad warships, great fleets of pleasure and commercial craft might have been built and put into commission. Instead of trenches and dugouts, the low-category dwellings of the people might have been replaced by garden city residences. Meanwhile, a large proportion of the population, including all the physically unfits, could have been conscripted for lengthy holidays to the Continent and elsewhere.

But the other more unpleasant symptoms which obtruded themselves as the European War proceeded would also have appeared eventually. How to avoid them is what we must discover.

\section{The Post-war Stagnation.}

During the progress of the Great War labour was gradually withdrawn from the " key industries " of peace, namely, food, clothing, houses and utensils. These were therefore used up at a greater rate than the rate of replacement, and the usual scarcity became intensified.

In the niggardly markets, profiteering became rampant in these and all other commodities, in spite of the vain attempts of Government "controllers" to regulate prices. The rising "cost of living" soon absorbed, and continued to absorb, all rises in wages, measured in purchasing value. It was short supply which caused high prices in the first instance, and really not, as it was frequently stated by the profiteers themselves, that it was due to the "pampered British working man," or that "the preposterously high wages of the lower classes forced up prices."

There were many contributory causes for the stagnation 


\section{FROM THE OLD TO THE NEW WORLD}

following the close of hostilities. It was natural for some disorganisation to take place in changing over from warto peace-time activities, but considering the long overdue necessities which called out for satisfaction in every direction, the period of stagnation did seem, and was indeed, far longer than was justified upon that account.

Instead of labourers returned from the war and liberated from munition work being quickly absorbed, there was so little demand for their services that it became a pressing problem to know what should be done for the army of "no occupation."

Munition factories were therefore retained in commission making war material, which was dismantled or destroyed afterwards, because, although about a score of smaller wars were in progress in different parts of the world, the dissipation at the main war area had ceased, and it became inconvenient to handle and store the output. It was therefore considered better, as an alternative, to pay unemployment doles to the discharged soldiers and munition workers, who therefore continued to be kept by those engaged in production. The latter were in dire need themselves very often, but there was the invisible barrier of land monopoly between the desire and the satisfaction of this potential demand.

To those not seeing the cause, it seemed as though nothing could be done for the unemployed, except to continue the doles and delay demobilisation. This perplexity may explain part of the apathy after the Armistice and the resistless drift into the adventure initiated by Mr. Winston Churchill in Russia, followed by Sir Hamar Greenwood's punitive expedition into Ireland, which had resisted military conscription.

The stagnation and discontent continued. One section of the community blamed the other for the high prices, low wages and unemployment. Trade-unionists were accused of opposing the employment of discharged soldiers, men and women were accused of taking a mean advantage of the dole paid through the labour exchanges to remain out of work, and yet thousands accepted work at ridiculously low real wages and salaries. Employers were blamed for taking advantage of the labour glut and paying such low 
remuneration, and yet the greater number strove not only to fulfil their promises given during enlistment, but to do better when possible. Goodwill was overborne by the operation of economic forces.

\section{The Shortage of Raw Materials.}

It was the shortage of raw materials, given as one reason for the stagnation, which was the clearest indication that there was constriction at the source of all wealth. But what raw materials really were, or whence they came, appeared to be somewhat obscure.

It was vaguely believed by the "Johnnies-head-in-air " that nearly all raw materials came from distant countries overseas, and that in view of the shortage of shipping little could be done for some time towards improvement. The blockade was retained long after the signing of the Armistice against the Germanic countries to prevent the precious raw materials escaping thither, and then, with inexplicable inconsequence, each victorious Entente Ally proceeded to blockade itself by a system of embargoes, restrictions, import duties and sur-taxes, piously believed to be upon finished and semi-finished materials.

It was subsequently discovered, after painful experience, that these goods in most cases were raw materials from the point of view of those who required them; that where they were not, it was far from being a case of "dumping" ; that some real "dumping" would have been like rain upon a thirsty land; and that the blockade against Germany was also a blockade against her enemies!

In the confused pursuit of the shadow it was taught that a country became wealthy upon what it sent out. "We live by our exports, we live by nothing else." (Sir A. Geddes, House of Commons, July I9I9.) This expensive Government expert did not explain that Britain had become a "subject nation," paying tribute in exports to foreign financiers, as, for example, those of America and Japan.

\section{The "Blessed" Debt and High Prices.}

Sir Auckland was gloomily pessimistic in the figures of comparison between British and American export prices. How could Britain hold a foreign market when her prices 


\section{FROM THE OLD TO THE NEW WORLD}

for steel rails, ships' plates, pig iron and coal were from 20 to 50 per cent. higher than the corresponding prices quoted by American suppliers, high as the latter appeared to be ?

Wages in America were at the same period substantially higher than in Britain, which perplexed those who attributed the higher prices to high wages.

The main war demand had ceased, and while supply was not profuse, there appeared to be, on the face of things, little to justify prices being maintained. But they were not only maintained, they were increased.

In the case of coal, the public almost discovered the fraud which was being perpetrated. It was pretended, in order to exalt prices, that coal was not plentiful, and to heighten the illusion supplies were immediately withheld from the domestic consumer. Government "controllers," controlled by force of circumstances and unable to satisfy the appeals of consumers, only assisted the trusts and trade rings in the process of deluding themselves and the public.

Although the primary industries of farming, mining and quarrying were notoriously understaffed, labourers were not taken into employment to increase production. They were discharged rather, and paid unemployment doles. In the secondary industries there was consequently enforced restriction of output, and it was if anything intensified by employers, who were unconsciously assisted by employees in their agitations and strikes for shorter hours in order to get their unemployed comrades re-engaged, and for higher wages to meet the necessarily higher cost of living.

Only the latter actions were noticed by an undiscerning public, who were herded like cattle in a shortened service of railway trains and served by inadequate station staffs. Unable to see, blinded with the dust raised by fruitless controversy, declaiming against the retailers, who had long since ceased to be profiteers, each section of the harassed community blamed the other for the high prices. Unemployment doles had meanwhile to be continued to those who would have been glad of an opportunity to assist fairly in producing the things so urgently required for their existence.

It was seen by few that the heightened prices, which put even ordinary commodities out of the reach of so many, 
were due to the natural desire to pass on to the consumer the taxes upon production, which went to pay, among other things, "interest " upon the National Debt. The war demand had ceased in a great measure, peace activities were delayed by the operation of the land monopoly, purchasing power was in increasingly fewer hands, and in view of the shortened demand, prices had to be advanced further upon those yet able to purchase than at first sight seemed necessary.

This was the reason for the hurried restriction of output which everywhere took place until a differentiating equilibrium was restored as between buyers and sellers. This was also why there was a tendency to force wageearners to a yet lower standard of living.

America's National Debt being lighter than Britain's, it was to be expected that commodities produced equally well in either country should be exported more cheaply by America.

\section{Producers and Consumers.}

By the time any article has reached the purchaser, it has generally passed en route through many hands before it is finished and finally produced. Primarily the agriculturist, the fisherman, the miner or the quarryman takes the raw materials from the earth and passes them on to the merchant, who supplies the secondary industries which prepare and manufacture them into new forms. From the hands of the industrial workers the goods find their way to the wholesaler or jobber, who attends to the wants of the retailer, who in turn satisfies the demands of the consumer.

The price of the commodity to the consumer must upon the average include the wages, salaries or profits of all those engaged in its production. When it is sought, therefore, to take from each individual a portion of his remuneration as taxes, there ensues a scramble by sellers to pass on the tax by means of an increase in price to the buyers in the chain of producers and consumers.

Thus the retailers, in a market already "short" owing to the action of the land monopoly, pass on their share of increased taxation, plus a little besides for collection, to the consumer, effecting the purpose by the exercise of a little further artificial restriction of supply. The wholesaler or 


\section{FROM THE OLD TO THE NEW WORLD}

jobber acts in a similar way to the retailer, who accordingly repeats the process as he passes the wholesaler's advance on to the consumer. In like manner the increases made by the manufacturer, merchant and the suppliers of raw materials, i.e. the farmers, miners and fishermen, also restrict output, and pass on their charges for taxes, and a little more to cover themselves, to be eventually loaded upon the price to the consumer.

It is easy to see that there comes a balancing time, when profiteering is out of the question for the retailer, who finds that turnover and small profits must have consideration. Later, the jobber finds himself in the same position; still later, the manufacturer, then the merchant, until finally the supplier of the raw materials is reached.

During the process, the suppliers of the perishable raw materials, like milk, ${ }^{\mathrm{I}}$ vegetables and fish, may find it more profitable for a short period to destroy some quantities of such stock, and sell smaller portions at an enhanced price

I In the summer of I9I9 the rich and powerful farmers induced the Food "Controller," who was a Labour or trade-union representative, to fix the price of milk so high that it was put quite out of the reach of thousands of poor consumers. In order to encourage its sale in the form of milk, the prices of butter and cheese had been fixed so low that it was no longer profitable to manufacture these commodities. The total effect of the interference was that there was an "overproduction" of milk, and gallons of it were destroyed, the farmers and retailers making good profits by selling the smaller quantity at the high fixed price and sending cattle to the meat market.

This constituted one of the many public scandals of maladministration, and in January I920 the unhappy "Controller " suggested the decontrol of milk, which drew forth a great storm of protest from the "protected" farmers. They threatened to go out of business, " the plough shall rust under the hedge," therefore the control was continued for a further period. It was a ludicrous situation, because the very persons who had opposed control were now advocating its retention, shrinking from the "draught" of free supply and demand.

A similar situation arose in the case of coal in the spring of I92I. The "control," which the general public imagined was keeping the price of coal down, was in effect keeping it out of their reach. They were therefore easily scared by the threats of the coalowners that they would raise prices when the "control" ceased. Coal was decontrolled, however, because it was found eventually that, instead of bringing in revenue, the industry was a charge upon the Treasury. Thereby hangs a tale! 
rather than sell larger quantities at a lower price. Such waste took place frequently in I9I9, when poor English children were famishing. Concurrently, it happened that the profiteers, grown rich in the war period, able to pay any price for food, were competing against each other for expensive motor-cars, paintings, jewellery and furniture.

The latter were plainly not being impoverished by the " blessed" Debt. They, at any rate, might well believe in the Government injunction, "To reduce the cost of living, buy Victory Bonds!'

But the wave of prosperity does not remain with the farmers, miners and fishermen, nor with those who bring raw materials from across the seas in ships. Man is a land animal, and the landlord, by exacting higher terms for the sale and lease of land, takes toll, and absorbs gradually any advantage, whether derived from greater intensive effort on the part of industry to meet increased taxation or resulting from lessened taxation by Government.

\section{All Taxation is paid by Industry.}

Whilst all individuals are consumers, not all are producers of goods and services. There are legitimate nonproducers, as, for example, children, the sick and the aged. There are also parasitic non-producers created by social maladjustment, as, for example, the bureaucrats, the armies of "no occupation," the broken loafers, the "idle-rich" hangers-on, the tithe devourers, the much-consuming landlords, and the bondlords into whose hands purchasing power is concentrated owing to the wage slavery caused by the superstition which permits men to "own" the earth.

In so far as these latter partake of such attributes, living upon the labour of others without giving fair exchange for services rendered, they are parasites, that is, consumers only, and cannot be said to pay taxes. They merely pass on a portion of the rents, private taxation or usury they extort from their fellows, to be expended ostensibly for the benefit of the community. All taxation must be, and is, a burden upon those consumers who are wealth producers.

As taxes are increased, therefore, upon the fallacious basis of ability to pay, to sustain the man-eating Thing, 


\section{2 \\ FROM THE OLD TO THE NEW WORLD}

" the invisible government of graft and greed," the total of wealth producers becomes less in number because more parasites are created, and because landlords, who sleep but thrive, exercise their power of monopoly to restrict access to the source of all wealth.

Industry pays all taxation, and it is for this reason that Mr. Austen Chamberlain, holding the unenviable position of Chancellor of the Exchequer in I9I9, besought the workers of hand and brain to redouble their efforts, or national bankruptcy could not be avoided. It was also for this reason that the workers, seeing idle hands everywhere, oppressed with the rising cost of living, ${ }^{\text {I }}$ struck and rioted in blind rage. It was not trivialities which brought these men and women to desperation. They were fighting for freedom.

\section{The Way to Real Prosperity and Happiness.}

Prosperity and happiness are not attained by anarchy or "Bolshevism." The perpetual motion machine, however, is not less possible than that prosperity can be perpetuated under an increasing load of debt to national and international moneylenders, all supported upon a narrowing base of useful industry. Real prosperity is possible only when there is free and active demand for goods and services intended for the commonweal and advancement of mankind, and that condition is only attained when the distribution of purchasing power is based upon the Natural Law of Equity.

Disaster cannot be avoided eventually by depreciation of the currency, nor by means of a levy upon "capital," nor even the cancellation of all debts. The shell of modern civilisation may not be threatened by the attacks of outer barbarians, but it contains within itself the landless barbarians of the slums, who know not Justice because it has been denied them so long, and who in their ignorant desire to possess the Clay Image of Property will not consider the dictates of Humanity.

Unless the base of industry is widened and the bubble of usury deflated by the uprooting of that superstition which produces wage slavery, disaster is inevitable.

I Due to higher prices and/or lower wages. 


\section{THE PSYCHOLOGY OF GAPTIVITY}

\section{READER'S GUIDE}

IN Chapter XVI is given a general review of the economic consequences resulting from the acceptance of the superstition that the earth may be bought and sold. The fallacies of the State-Socialists, tradeunionists and protectionists are exposed.

The Headings are:

Slaves of the Vineyard of Monopoly-Modern Intensive Production-Manufacturing Tantamount to the Intensive Cultivation of the Land-The Effect of Vested Ignorance upon the Production of Goods-The Effect of Vested Ignorance upon the Production of Ills-Trade Unions and Craft Guilds-The Minimum Wage Myth and the Sham Housing Scheme-Hatred of the Foreigner and the Employer-Federations, Trusts and Rings-Economic Aberrations-Secondary Capitalistic Monopolies-Monopolies fostered by Excise and Customs-Monopolies fostered by Domestic Tariffs-Taxes upon Incomes and Profits-Spurious Socialisms-" Socialism is National Organisation"-_"Walking through Dry Places, seeking Rest"-The Prison swept and garnished-Entry of the Seven other Wicked Spirits- " The Path on the Way to Hell is paved with Good Intentions." 
$\mathrm{He}$ that is not with $\mathrm{Me}$ is against $\mathrm{Me}$ : and he that gathereth not, scattereth.

When the unclean spirit is gone out of a man, he walketh through dry places, seeking rest: and finding none, he saith, I will return unto my house whence I came out.

And when he cometh, he findeth it swept and garnished.

Then goeth he, and taketh to him seven other spirits more wicked than himself : and they enter in, and dwell there : and the last state of that man is worse than the first.-LUKE xi. 23-26. 


\section{THE PSYGHOLOGY OF GAPTIVITY}

\section{Slaves of the Vineyard of Monopoly.}

Imprisoned by land monopoly, what time superstition holds their fellows in thrall, captains of industry seek to overtake the devastation and poverty of society by intensive production. For a long time their efforts appear to be successful, but misfortune overtakes and dogs their footsteps.

To those who clearly see the road to freedom, mankind in the mass learns so slowly that the day of liberation seems afar off. It seems as though every idol in the paradise of fools must be cracked up and pulverised by the operation of Natural Law before bruised Humanity consciously recognises the Rule of the Land.

James Watt, who invented the modern steam engine at the end of the eighteenth century, was aware of the hostile environment surrounding new ventures. In a letter dated April I7, I786, he wrote to his partner Boulton disapproving of the action of an assistant in showing the new child of progress to those who reap and do not sow.

He said: "Everything which renders us conspicuous should be avoided; let us be content with doing. John Rennie no doubt has vanity to indulge as well as us, but he should be curbed and the bad consequences pointed out to him. Dukes and lords and noble peers will not be his best customers."

It was at this period when, before the French Revolution, the Physiocrats, Quesnay, Le Mercier de la Rivière, Turgot and others, were endeavouring to liberate France by means of the Subvention Territoriale. Alas! came along the Red Terror, and the perishing people, who had not learnt their lesson and who were attacked by aberrated "rescuers" from without, wandered into aimless mazes with the halter 
of superstition round their necks, in due course to be harnessed by the tyrant Napoleon to the car of imperialism.

Watt, like Adam Smith and other enlightened Englishmen, was fired by the enthusiasm of the French patriots, and in a letter of February Io, I787, to his friend l'Abbé Colonne, expressing admiration of the way the Controlleur-Général proposed to simplify taxation, said, "But that part of our patriots who are not over-liberal fear that he will, by freeing your commerce and agriculture from its shackles, make France too rich and too great for the welfare of Britain and its trade. We argue otherwise, for we say that if these measures contribute to increase your manufactures or commerce, that our Government will be obliged to lay aside the erroneous part of their system, and free our manufactures from their grievances, and that the richer France becomes, the better customer she can be to Britain, and that at the worst, if no change of system is adopted here, and our trade becomes ruined by the aggrandisement of yours, that you will have made France so desirable a country that all active men, who are not rooted to the soil like so many vegetables, will remove thither, and help to make it still greater, leaving our tyrannical landholders to pay the National Debt, to eat their own corn, and muddle their undertaking with their own ale."

The inventor referred to a small treatise on the subject of taxation "which I composed in a fit of rage at the imposition of several new taxes on manufactures: but which I have reason to believe was productive of no good effects, so infatuated is our Government in its endeavours to kill the hen which lays the golden eggs, and so tenacious are our landed gentlemen of what they call property, reckoning us poor mechanics no better than the slaves who cultivate their vineyards. ..."

\section{Modern Intensive Production.}

The story of the farmers, who fondly imagined that as the domestic pets of the predatory landlords they would not be devoured, is being repeated in the case of the artisans and craftsmen, who became manufacturers, miners, shipbuilders and traders, employing the reservoir of landless wage slaves at minimum wages. These latter were thus enabled 
at odd moments and in varying degrees to improve their condition.

Wealth producers are naturally impelled to co-operate, because in production twenty men working in fellowship produce more than twenty men working singly. There is a constant tendency to satisfy desire by the expenditure of the minimum of effort, so that compulsory co-operation is an anomaly. In any system requiring compulsion, selfinterest is extinguished and the full benefits of co-operative effort are not secured. Slave labour at all times is inefficient and unsatisfactory, and impulsion can always outrun compulsion.

The invention of the steam engine enabled private enterprise to get a start upon the elastic barrier of the land profiteer, and for a time substantial benefits accrued to manufacturers and other wealth producers employed intensively. It marked the birth of the so-called middle class, the continued existence of which now seems imperilled.

As in the case of the farmers, who introduced the Dutch methods of agriculture, the natural co-operation of craftsmen in manufacture who introduced steam-power has decayed into compulsory industrial slavery. Leadership within the closing barriers of the land blockade has deteriorated into slave-ownership.

\section{Manufacturing Tantamount to the Intensive Cultiva- tion of the Land.}

Under the guiding influence of human thought and action, the raw materials taken from the earth by the miners and quarrymen are transformed into new and useful forms by the manufacturer, much as the intensive market gardener grows flowers, fruit and vegetables. The potentially stored up, and the kinetic heat and light of the sun, are as potent and necessary for the "growing" of houses, bridges, ships and locomotives as in the culture of cabbages.

Raw materials can only come from the carth, that is to say, from the soil, the air or the water upon the surface of the earth. There is nowhere else than upon the earth that the process of converting raw materials into manufactured forms can be carried on. Houses can only be erected upon it, trains can only run upon it, and shippers and traders 
must have stations and sites for mooring berths, warehouses and offices of administration.

All wealth producers, and those who serve and depend upon them, work upon land in the economic sense, upon materials drawn from the land, sometime, somewhere, somehow. Even the "Johnnies-head-in-air," who have not wit enough to realise the importance of their relationship to the earth, come themselves from the only source of riches, and are returned to it after they have ceased from their protestations. Nor can they take away with them the title to their own honest labour, nor the robbery of that their fellows are justly entitled to.

The superstition that a few may own the source and mother of wealth, to which labour is the husband, and that these few may compel all others to pay tribute to them for life, is an adequate cause for the huddling of people into slums, the depopulation of the country-side, the unemployment and poverty of the would-be industrious, and the monstrous inequalities threatening the very existence of civilisation such as it is.

\section{The Effect of Vested Ignorance upon the Production of Goods.}

Property in land is not like property in goods, because an assumption of absolute ownership in land on the part of any person is a perpetual denial of the equal right of others to live. Consider the effect upon employment and production of the power given to the landed monopolist to withhold the use of land for way-leaves, either by blank refusal or conditional upon the payment of exorbitant "dead rent," indemnities and legal costs, and payment of royalties.

In agriculture, one thousand men debarred from growing food-stuffs does not begin and end in one thousand men being unemployed on gardens and farms. It means also that hundreds of others, who would otherwise have transported, manufactured and retailed the articles made from the cereals, fruit and vegetables grown by these labourers, had they been allowed, are debarred from earning a living. Similarly, in the primary industries of coal and oil winning, the mining of metals, quarrying and clay getting, there are far-reaching effects to follow when labour is debarred or restricted by the 
toll-gates of privilege in its application to the source of riches.

Not only is one industry, say engineering, irrevocably dependent upon mining, agriculture and all other industries for prosperity, but individuals with useful services to offer for the conservation of happiness in exchange for goods and other services must go short when access to land is denied to industry by the vested ignorance of the community. Doctors who care for the health of the body, ministers and teachers who devote themselves to the training of the mind and the building of character, musicians and dramatists who amuse, delight and instruct, are rendered idle or are poorly paid, along with clerks, draughtsmen, designers and chemists.

Some slight conception of the effect is given when a strike or lock-out takes place in a primary industry like coal-mining. Such a temporary disturbance in the great body of industry is like the ever-widening circles produced by a stone thrown into a pond, which in time reach and disturb areas far away. But whereas a strike or lock-out creates a temporary disturbance in industry, the continuing wrong in land tenure creates a permanent, universal, malignant disturbance in production, which tends gradually to get worse, and which cannot be gauged in its great extent because there is no peaceful prosperity to measure it by.

\section{The Effect of Vested Ignorance upon the Production of Ills.}

It is not surprising, in the circumstances, that although the power-loom has reinforced handwork, that the steam shovel and motor-plough have assisted the spade, that the electric crane has been put alongside the hand winch, that although wealth production in its multifarious intensifications has been introduced into every direction, yet the masses of wage and salaried slaves have not obtained anything like commensurate benefit in lightened toil and anxiety.

The wealth producers, whether leaders or rank and file, have not more leisure than before these inventions existed, but less, because "it is the pace that kills." They, not less than those who have the miserable leisure of unemployment thrust upon them, are not able to aspire to higher things in the pursuit of happiness. For relaxation they fly to 


\section{FROM THE OLD TO THE NEW WORLD}

mental and physical intoxications, and, strained by overwork, pursue transient excitements in error for enduring happiness.

In spite of the ingenuity expended in labour-saving devices, little children are yet called upon to toil when they should be occupied in healthy games or in the joyous cultivation of their awakening physical and intellectual powers. Women prematurely lose their health and comeliness in souland-body destroying drudgery or atrophy into social molluscs and vampires.

Industry rarely accumulates happiness for the mellow ripening of old age, but rather ills which overburden worn-out lives, filling anxious decline with deepening shadows of misery. The less fortunate have to be supported by their children, which is unnatural, or they are scantily assisted with State doles to exist in the earthly hell of humiliation.

Labour-saving devices, instead of lightening human toil, have only made available a greater reservoir from which is drawn the crazy sacrifices of aberrated intelligence. Instead of profuse production in the "key industries" of peace by speedy and thorough methods we have therefore profuse production in the "key industries" of war. Poison gas, shells, torpedoes, guns, battleships, aerial bombing machines increase at a greater rate than food, clothing, houses, utensils, gardens and services necessary for human happiness.

Many who build houses for others live overcrowded in hovels themselves; many who produce food for their fellows have famished dependents; and many fabricators of fine raiment are themselves and families clothed shabbily. Many makers of furniture and household requisites have themselves to go without, and although they produce for others with such wonderful facility, the vast majority of hand and brain workers in present circumstances cannot command for themselves the desirable commodities they fashion with the materials provided with such profusion by Nature.

Nevertheless, these are the inevitable consequences of the land blockade, which creates niggardly production and the unemployment which results in forced labour sales.

\section{Trade Unions and Craft Guilds.}

All craftsmen feel the terrible consequences which arise from the one-sided competition of men for jobs, but few 
know why this unnatural competition exists. Even the followers of Karl Marx in the workshops, feeling far remote from the land, fail to realise the significance of his most important statement: "The basis of modern Capitalism is the expropriation of the labourer from the soil." (Das Kapital, last chapter.)

Trade unionists and craftsmen in the past, instead of seeking to abolish the unjust system, thought that the iniquity of property in land was only an unimportant part of social maladjustments. They have therefore largely wasted their energies in vain collective bargaining for higher wages and shorter hours of labour.

They have always been defeated, even when apparently they were most successful, because, just as in virtue of the " corner" made by land monopoly taxes can be handed down upon industry, so likewise any general improvement in industrial conditions is absorbed by restriction of supplies and higher prices in the already straitened market. This process is finally reflected in higher rents, higher taxes of Government to aid law and order against a disappointed proletariat, and greater "profits" to monopolists who flourish owing to the land blockade, within which barrier the "vicious circle" moves.

By means of the limitation of those permitted to learn a trade, together with artificial restriction of output, trade unionists struggled to keep their wages almost level in purchasing power during the fifteen years prior to the Great War, but in the same period the unskilled labourer found that commodities were put increasingly further out of the reach of his purchasing power. Indeed, in general, food prices rose concurrently twice as fast as wages, and the condition of the unskilled labourer became pitiable in the extreme.

\section{The Minimum Wage Myth and the Sham Housing Scheme.}

It may be forgivable for unthinking people, like children, who in a railway train think it is the landscape which moves, to fancy that good wages is the cause of high prices, but it is difficult to repress a feeling of contempt for "Liberal" reformers, and even Labour representatives, who endeavoured to fix wages according to the cost of living. It became 


\section{FROM THE OLD TO THE NEW WORLD}

fashionable, for those who believe that kindness can be put in the place of justice, to measure to the nearest farthing the cost of maximum bearable domestic discomfort, and to associate themselves with a "National Minimum Wage" policy and an alms-" Housing Scheme."

Highbrowed politicians and super-writers upon economics really thought it was necessary to dispense charity to the indispensable labourer to enable him to subsist. They were deaf to the call of Justice.

Subsequent to the signing of Peace in Versailles, the "Great Charter of Labour" has been put forward as a plank of the League of Nations enthusiasts, some of whom thought that an "International Minimum Wage" might be fixed. Others, sublimely innocent of the true state of affairs, joined hands with the delighted monopolists of every country. The well-intentioned ideal is a system of tariffs arranged by the League, so that the cost of living may be kept the same in every country, maintaining the existing standard of living.

" He passionately desired an international comity of goodwill, but while he wished this country to be an asylum to persons from foreign countries, he desired protection from spies. He was aware of the danger of blackleg cheap foreign labour, and he appealed to the Home Secretary to take steps to maintain the standard of living of the British workmen." (Mr. Ben Tillett in the House of Commons.) Mr. Ben Tillett was doubtless misled by appearances. It is incredible that a Labour Member should deliberately imply that the labour of his workmates was overpaid and that foreign spies might discover this awkward fact!

\section{Hatred of the Foreigner and the Employer.}

Not seeing that poverty arises from the embargoes put upon free production in their own country, there is a tendency for trade unionists to attribute their misfortunes to other things. They frequently, and in varying degree, blame foreign competition for low wages, and distrust and dislike the foreigner accordingly, and at the same or at other times blame their employers for selfishness in paying such low wages, forgetting that employers compete severely with each other for work as the employees of customers. 
How employment and wages of industry can be increased in the long run by the reduction of the number of employers, which happens when the foreign customer is excluded by preventing him from paying for commodities and services in return, is possible only in the hallucinations of economic enclosure.

\section{Federations, Trusts and Rings.}

Employers in an evenly balanced society would earn profits or wages which would represent the due reward of their industry. Living, on the contrary, within the same hostile environment due to the land blockade as their fellowproducers, the trade unionists; their federations, combines, trusts and rings acquire the same malignant characteristics as the unions in the unnatural struggle for existence.

While the original intention of such leagues may have been to favour beneficial co-operation in trade and commerce, they are gradually forced by circumstances into oblique directions, to their ultimate disadvantage.

This tendency is accelerated by taxation according to " ability to pay," which in the endeavour to pass on causes them to restrict still further the already "short supply" and in concert to plunder the consumer. But since we cannot hurt others without hurting ourselves, in militating against the consumer the combinations of employers and unions of employees find the struggle for existence harder as time goes on. Crises recur from time to time in which there is "overproduction" due to underconsumption, because the producers themselves are consumers of each other's products, deprived by circumstances of the power to purchase.

Moreover, the leagues and unions do not collaborate to improve production and exchange to the advantage of industry as a whole. They contend with each other, and league preys upon league, as union jostles with union in the losing game of "beggar my neighbour" for everyone.

\section{Economic Aberrations.}

Like the trade unionists in general, the federationists are in the main obsessed with the fallacy that the "means of production " is capital, and that wages, salaries and other 


\section{FROM THE OLD TO THE NEW WORLD}

profits come in some mysterious way out of capital. They do not comprehend that all wealth is the product of hand and brain or mind applied to land in some form or other, and they do not recognise sufficiently clearly that in a great measure what is returned in their balance sheets as "capital assets" is as substantial as the foam of the sea.

In their philosophy of economics it is not taught that real capital in the form of buildings, machinery and stockin-trade is employed by labour, but - weirdest of doctrines ! that capital employs labour.

Under the influence of this superstition, which is of the psychology of captivity, it is difficult for them to believe that when labourers, skilled and unskilled, including craftsmen, clerks, draughtsmen, salesmen, travellers, managers, foremen and directors, receive the just reward of their industry in economic free competition, there would be true co-partnership, in which each producer would have a fair share in the possession of the farms, factories and circulatory services. In sucb a case there would be no outside bondholders or usurious so-called capitalists, but each business would become a co-operative one, possessed by the persons engaged in it or serving them.

In the economic enclosure of restricted opportunity and niggardly production of goods it is hard for the captives, wriggling to escape from the horrible consequences of cut-throat competition, to believe that competition in economic freedom with equality of opportunity for all is enjoyable. It does not easily come within the field of their narrow vision that such competition is the healthy rivalry of emulation making for progress, prosperity and happiness-is indeed co-operation to serve consumers.

\section{Secondary Capitalistic Monopolies.}

All capitalistic monopolies have their origin in the slavery arising out of land monopoly. Beginning in honest husbandry, manufacture or commerce, wealth concentration, due to the exploitation of the dispossessed, leads to the establishment of powerful commercial magnates. It was so in the case of the Merchant Princes of Italy, of the Hanseatic League, and it is to-day of the Big Five Meat Trust of Chicago and the great banking amalgamations. 


\section{THE PSYCHOLOGY OF CAPTIVITY}

Many of these monopolies are "vertical" trusts, that is to say, their power is entrenched doubly, because they monopolise mineral deposits in the earth by the acquirement of "rights" and governmental "concessions" over the public domain. The Standard Oil Trust holds extensive tracts of oil-bearing regions, obtained by the coalescing of many other companies and the "freezing" out of others. By closing up wells to restrict supply, the trust is enabled to tax and plunder the consumer. They can do this because, paying no rent to the public, it costs nothing to hold valuable oil-bearing land out of use.

The power of the Steel Trust is due in a great measure to an exclusive possession of coal and ore deposits, the working of which they restrict and control for the purpose of obtaining profiteering prices from consumers. The increasing difficulty in obtaining timber supplies is not because timber in the world is being used up at a greater rate than it is being replaced by new growths. This is simply the psychological effect upon the minds of deluded consumers. The fact really is that the natural forests of Europe, America and elsewhere have fallen into the hands of the few, who enslave the many in precisely the same way that the coal trusts do.

The short supply of food and other raw materials by the action of land-withholding gives rise to speculative buying and selling of commodities by middlemen. These exchange gamblers do immense harm by the exaltation of prices and the "cornering" of cargoes, which they never see and never intend to retail themselves. The prices may be forced up by this false commerce to such a height that there is recurring congestion at the docks, warehouses and railway sidings because speculation has run beyond the purchasing power of the legitimate consumer.

In such cases operators, in holding up against the extreme necessity of the community, hoping vainly to obtain a price which will cover them from loss, have fallen victims to their own greed.

There may be a spectacle, therefore, of appalling waste of perishable goods at the clearing centres at times when the community is confronted with famine. Dockers and warehousemen, prevented day after day from the carrying out 


\section{FROM THE OLD TO THE NEW WORLD}

of their duties, may be thoroughly disgusted, and it is not surprising that they sometimes complete the disorganisation by obstinately refusing to work, when at last they are allowed to proceed, unless they are paid some addition for time wasted.

The misdeeds of the dockers are held up for execration by the hate propagandists, and the public are led to believe that the high prices are entirely owing to the high wages of workmen. As a curiosity of the psychology of captivity, it is by no means infrequent that the superstitious people are told by their favourite newspapers that the high prices are due to their own insatiable "greed." This piece of impertinence is, of course, the corollary of the fiction that it is high wages which is the sole cause of high prices.

The middlemen gamblers, when successful, are openly admired by the sycophants of our modern banditti, and it is indelicate in their presence to draw attention to the original cause of restriction of supply which rendered the intermediate robbery possible.

Superfluous middlemen and their disastrous gambling could never flourish in a profusely supplied and regular market. Moreover, the power of the "vertical" trust to restrict supply at the source could not long survive the payment of "dead " rent to the community for the portion of the public domain which it monopolised. It is the omission to take the economic rent that attaches to land by reason of the growth and progress of society for public purposes which is the cause of unemployment, scarcity of goods, speculation, inefficiency, low wages, and concomitant high prices.

The disappearance of unemployment means the abolition of wage slavery or so-called capitalism, because it is this unemployment which prevents profits, the reward of industry, salaries, all included in the term " wages," from rising to the economic maximum.

As civilisation is at present constituted, endeavour is directed not towards progress, but towards the deterioration of the standard of living. The race is not in the pursuit of improvement in conditions of life, but a foolish competition in the art of "doing without," and this very attainment is put forward as a Christian duty by gloomy clerics and those who grind the faces of the poor. 


\section{Monopolies fostered by Excise and Customs.}

The action of the excise duties tends to prevent the establishment of new breweries and distilleries, which would otherwise induce healthy competition in the service of the public.

By means of adequate restriction of supply (the demand remaining not less than before among a population seeking to drown its woes and sorrows in strong drink) the existing breweries and distilleries find it easy to pass on to the consumer increases in taxation plus a tax for themselves. The prices are increased, and/or a poorer and more pernicious product is retailed. The powerful "trade" may make a pretence of opposition to the imposition of excise duties for the purpose of deluding the consumer, but they would be as eager as the most valiant teetotaller in resisting their abolition.

Importers of tea, coffee and tobacco are given a similar privilege, the import duties on these articles of common consumption discouraging the springing up of new traders. It is, of course, the consumer and not the Chinaman or other foreign producer who pays the tax, which bears most severely upon the poorest of the population. In all such cases the price is put up more than sufficient to cover the increased taxation as it takes place.

In countries like America, which adopted import duties upon manufactured articles supposed to be paid by the foreigner, the specious plea is made by "big business" that "The duty is put upon goods to cover the differential between the American and foreign standard of wages for the protection of the working man." This hypocrisy is discounted by the fact that wages and salaries in the businesses so "protected" are upon the average lower than in similar concerns built up in the face of foreign competition.

Import duties foster the formation of trusts, which buy up or "freeze" out all employers who refuse to enter the "ring." The monopoly once formed, works are run shorttime or are closed down, staffs are reduced, and prices are raised to the point at which the greatest plunder is obtained, having regard to the differentiation of supply and demand.

Sometimes the increased price checks demand further than is expected, and the momentum of production carries 


\section{FROM THE OLD TO THE NEW WORLD}

supply beyond what has been calculated upon. This is called " overproduction" by " big business," although dependent industry in the home market may be going short because consumers cannot afford to pay the higher rate.

Until the trust can adjust matters by discharging more " hands," and until the enslaved customers of the monopoly recover themselves, the "overproduction" is " dumped" into some foreign, not necessarily free-trade, country. This action greatly enrages the manufacturers in the foreign country, who are doing all they can probably to build up a monopoly there for themselves.

Were there free production, the expediency of free exchange would never be questioned. The dreaded foreign competition would then be seen to be a bogy, while the so-called "dumping" would be regarded with as much amusement as a shower of unexpected presents from an unlikely quarter.

It is the scramble which ensues owing to the embargoes put upon free production within the limits of each country that is responsible for the "jungle theory of international relations." Tariffs do harm neighbouring peoples, but they harm the "protected" nation very much more. Nevertheless, in short-sighted revenge, a tariff war may be started, in which reprisal is followed by counter-reprisal. International hatred grows ever stronger, ending in the will to war, and the belligerents do not see that they are individually and collectively to blame in clinging to a superstition, a deference to which strikes a fatal blow at the root of real prosperity and happiness.

\section{Monopolies fostered by Domestic Tariffs.}

Not possessing the revenue from the economic rent of land, the community suffers the heavy expenses due to the necessity of providing for the mentally and physically unfit, sustaining a horde of bureaucratic officials, moneylenders and tax-eaters, and supporting large military establishments for restraining desperate populations within the barriers of land monopoly. Public expenditure is therefore not only high, but it must be met by funds drawn from immoral sources.

In France, for instance, towns are "protected" from the 
dumping of food-stuffs and fuel by means of a tariff wall called octroi duties, in much the same way that the coal supply to London was restricted some years ago by means of a tariff upon what was supplied from the provinces.

It is possible that this method is favoured because the consumer is scarcely aware that he is being taxed, and that he cannot easily evade it, certainly not that it is desirable to encourage the production of food-stuffs or the mining of coal within the "protected" city area!

In England there once existed a window tax, and each citizen was assessed according to the area of window glass of his house. Windows got smaller and smaller or were bricked in, and in time almost disappeared. The tax, although several times increased, brought in a falling revenue, and was finally discarded mainly for this reason, and not really in the interests of humanity.

After this atrocity it was thought better by the legislators to place the tariff upon the dwelling-house or factory in the form of rates and inhabited-house duty, and the poor, in spite of all attempts to solve the housing problem, have had to remain overcrowded in bad old houses in a scabious incrustation of decay, or be grateful for tiny brick boxes, fitted with larger windows, it is true, but provided with small backyards, and generally constructed to meet the requirements of landlordism and the most predatory taxation system of modern times.

Aberrated reformers, viewing things from the inside of the barrier, which they fiercely ignore, can think of no better solution to the housing question than civil barracks financed by grants-in-aid to county and borough councils out of the imperial exchequer. It is of the psychology of captivity that they say private enterprise has failed miserably, and that they imagine, in spite of painful experience to the contrary, that public enterprise has been any more successful.

Consider how private enterprise is penalised. The late Lord Charles Beresford told how they act in China. "Fancy," said he, "a Chinaman has the good sense to build himself a comfortable house or establish a business. Along comes the tax-collector. He looks round and says, 'This house or this place is very good; you must be a rich man; you will have to pay many taxes'-what can you 


\section{FROM THE OLD TO THE NEW WORLD}

expect from people who treat their enterprising citizens like that?

Yet this is precisely how enterprising citizens are treated in Great Britain and many other countries of the supposed superior Western civilisation.

So long as valuable sites are vacant or carrying broken down "improvements," the abusers pay little or nothing towards the communal expenses, as, for example, the policeman who warns off trespassers. If, on the other hand, enterprising individuals wish to make better use of the site, by establishing or extending a useful business, which increases wealth and decreases unemployment, they are confronted with serious hostility.

It is right that the owners of slums (say) should be amply compensated by the new-comers for their private property, but it is not just that industry should have to acquire way-leave by the purchase of land value created not by the holder, but due to the presence of population generally and inflated by speculation upon future prosperity of enterprise. Neither is it just, as an alternative, that labour of head and hand in its necessity should be obliged to submit to an onerous lease for the site, and agree at the end of the period that accumulated capital, or other rewards of industry, should become the property of the ground landlord.

As regards the latter, it is sometimes said in extenuation that the tenant accepts such plundering terms with his eyes open, or in other words, that the robbery is perpetrated in the daylight according to the laws of the country. Also that the landlord, if becoming civility is accorded him by the tenant, will graciously accept an indemnity or premium and grant another lease when the existing one expires. In this way the anxious tenant is shorn periodically instead of being slaughtered outright.

Is not the pathetic gratitude of the lamblike tenant to the kind shearer an interesting psychological study? Nor is the mental attitude of the conveyancing jackals disguised in sheep's clothing, who infest the enclosure, less amusing. Superstition makes fools of us all!

But the industrious user of a site who has paid heavily for it, and the tenant who has made improvements, possibly as 


\section{THE PSYCHOLOGY OF CAPTIVITY}

a condition of an extended leasehold, are not long left in the consolation and enjoyment of having bought peace at any price. Like their forefathers who paid Danegeld, they find that fresh invaders appear suddenly to strip them of the remaining fruits of their industry. Along comes the public tax-collector, who, assessing upon the same scale as the brigand, fines occupiers every few months according to their industry and appearance.

The new-comers, possessing better buildings than the previous encumberers of the site, are made to pay in rates and taxes many times more, and the improving tenant also has his assessment raised according to appearances, which may or may not be an indication of his means.

When it is remembered that this sort of thing is almost universal, it does not require much imagination to understand the cause of the shabby, mildewed and blighted general appearance of villages, towns and cities. If the system had been deliberately invented for the purpose, ingenuity could not have been more efficiently misdirected towards the creation of sordid and depressing reality. Enterprise does not pay, because it is severely discouraged by law.

The inhabitants are necessarily affected by their surroundings, and it is no wonder so many captains of industry are the embodiment of blank disappointment and that the masses of the people are hopeless and despondent. Blind as to the cause of the plight, forced optimism substitutes divine discontent, and the apathetic proletariat have to be stung into action by the foolish sarcasm of Government posters on the hoardings I directed against their supposed lack of native enterprise.

In such a hostile environment there is ever-present stagnation of industry in varying degree, so that it has been sometimes said "A good war is required to liven up trade."

It is largely due to the domestic tariff of the rates that there is a shortage of houses and other buildings-and in Great Britain the similar taxation of fixed machinery is an added disability to expansion.

I This refers to a Government poster following the Armistice, which was framed to the effect that the Germans "are delighted" to hear of the failure of the workers to produce more while their erstwhile competitors were hors de combat. 


\section{FROM THE OLD TO THE NEW WORLD}

At odd times the artificial limitation of these necessities produces a privileged position for those already supplied, and such a condition is intensified when new taxation has been imposed upon industry to support large armies and navies and to pay tribute to moneylenders, as during the Great War. The effect was seen in the prohibitive prices, which were inflated still further by speculation, of building materials among other things.

The monopolists are short-sighted when they are reluctant to see a change from a rating system which violates the moral law, for we eventually and inevitably suffer ourselves by selfishly subscribing to an unjust arrangement to secure a momentary benefit.

\section{Taxes upon Incomes and Profits.}

It is easily demonstrable (see previous chapter) that all taxation is paid by industry. Income tax and the so-called excess profits duty are not only burdens upon trade, but cause poverty to become more widespread.

The majority of the unskilled producers, living as they do, owing to wage slavery, near the border-line of starvation, have their standard of living certainly further depressed by rising prices; but since to exist at all they must have some nourishment, there is a minimum beyond which it is impossible to go without outbreaks of extreme riot and violence. In spite of appearances, all sections of society resist civil commotion, hence there are put forward plans of public and private charity, which outrage human dignity and turn into beggars and paupers men who would support themselves and families, given access to land, the only source of riches.

The history of Christendom, the recent events in Russia, the hanging storm of discontent everywhere, afford ample proof of the futility of the pseudo-charity that discards and denies the great Natural Law of Equity. The justice of Nature laughs at the attempts of men to give alms, or to rob the industrious to give to the voluntary and involuntary loafers of high or low degree, while not respecting the equal rights of all men and women.

In the struggle to avoid unemployment, not only are the so-called unskilled affected, but the skilled and salaried producers have also their standard of living depressed nearer 
the level of the unskilled, and this tendency is carried throughout the various gradations of the industrious. The latter category we wish to make as wide as possible, to include teachers, doctors, dentists, nurses, scientists, composers and musicians, poets and writers, and last but not least the mothers.

Taxes upon incomes or profits (which when evaded, as they are extensively, are evaded most successfully by financiers, gambling speculators and non-producers) also simply result in general limitation of output of goods. They cause more unemployment, and the depression of the standard of living for all except the few, who include the monopolists and the tax-eaters. More employees live from hand to mouth, and more employers live upon the verge of failure.

By means of these and other taxes upon production and exchange, the Governments of all countries not only rob their industrious citizens, but encourage the breeding of a multitude of rogues, who as monopolists gather private taxes from the public, or who as bureaucrats eat up the national wealth.

It is useless in these circumstances to urge the speeding up of output within the barriers of denied opportunity, for although the discouraged workers do not really appreciate their captivity, they see that the fruits of their industry fall into the lap of privilege, and that more men are unemployed because of "overproduction". when the narrowed market has been flooded by speedy methods.

The refusal of the exploited workers to turn the treadmill round faster is not because of laziness: "the complaint of labour to-day is against producing for the prodigality of private individuals." (Letter from six A.S.E. Branches to General Secretary Mr. J. T. Brownlie.)

There is a psychological difficulty, however, in the way of a general understanding that all taxes upon production and exchange fall upon the producers and traders and act so as to make profiteering monopolists more powerful. It appears at first sight reasonable to believe that a levelling up of wealth can be accomplished by taking off top branches and throwing these down to the ground.

Superficial thinkers, although they may protest against income tax for themselves, are unable to perceive that unequal distribution of wealth cannot be rectified by super income 


\section{FROM THE OLD TO THE NEW WORLD}

taxes or excess profit duties for others. The paradox can only be resolved by looking at the problem from the right point of view, that is, as a dynamic equation and not a static one. The pruning of incomes and profits does not tend to the equalisation of wealth, but instead, causes gross cultures to flourish more luxuriantly amid the keener struggle for existence. The diminishing few wealthy persons become richer in virtue of their increased monopoly power, and poverty creeps in upon them from the circumference.

It is of course true that if evasion could be prevented by superhuman supermen, and all incomes except a National Minimum confiscated, and all profits taken for the State, a levelling up would be accomplished, but it would not be the equalisation of wealth! As among the Terra del Fuegians and other coercive communists, there would be no industrial " surplus," there would be the equal distribution of poverty.

The State is not entitled to pick and choose what it shall tax or take. The State, like the individual, must conform to Natural Law or suffer condign consequences.

\section{Spurious Socialisms : "As against the State, we have no Natural Rights." (Mr. Sidney Webb.)}

Just as the ideals of Christians have been decomposed until there are many kinds of Christianity, most of which are wholly faithless to the gospel of Jesus, so similarly the ideals of the Brotherhood of Socialism, which are of His philosophy, have been shattered into countless inversions or slaveries.

Conceived of envy, hatred and malice, engendered in captivity, there is born of ignorance a belief that if the few rich individuals could be stripped of their possessions, then poverty could be eradicated. Nor is this blind antagonism directed against useless landlordism and predatory monopoly, but rather against those whose superior energy and foresight have enabled them for the moment to outrun the wolves of privilege. Such an erroneous belief is at least as dangerous as that no social improvement is needed or is possible.

The false prophets of Socialism may not subscribe wholeheartedly to this error, but they defer to it when they teach that freedom is not possible, even economic freedom. "If a man wants freedom to work or not to work, just as he likes, he had better emigrate to Robinson Crusoe's island, 
or else become a millionaire. To suppose that the industrial affairs of a complicated State can be run without strict subordination and discipline, without obedience to orders, and without definite allowances for maintenance, is to dream, not of Socialism but of Anarchism." (Mr. Sidney Webb.)

So little do they know of freedom that they mistake imprisonment upon a desert island for liberty, and the condition of the poor rich millionaire, raised above touch of humanity, surrounded by flatterers and sycophants, as one of happy carelessness!

Therefore they follow the deranged Nietzsche into the further recesses of captivity and echo that " Every strengthening and elevation of the type 'man' also involves a new form of slavery."

The theories of the fragmentary Socialists are indefinite and their doctrines are mutually destructive. Frequently regarding those engaged in private enterprise as "private adventurers," they ignore that it is private enterprise which initiates, invents, improves and establishes, and forget that it is public enterprise which copies and follows. Yet they frequently applaud the private enterprise of the founders and directors of Co-operative Societies, failing to see that there is no essential difference between a Co-operative Society, the shares of which are held by working men, and the Joint Stock Company, the stock of which may be held by any members of the public.

The co-operative societies compare favourably with the well managed ordinary firm of manufacturers and traders in the payment and treatment of their staffs, but they likewise come into conflict with their "hands" in regard to wages and hours of labour. They cannot, in present circumstances, avoid lock-outs and strikes.

Similarly public enterprises, the shares of which are held by the community, as, for example, the State Church, the schools, the police and military, the post office, telegraphs and telephones, the State mines and railways, where they abound, are they any more successful than private cooperative enterprise? Is the conduct of their affairs more satisfactory? Do they serve the public better? Let us be just; within the barriers of the Great Land Monopoly, 


\section{FROM THE OLD TO THE NEW WORLD}

is Government enterprise any less predatory than the "private adventurer"?

We refuse to believe, because experience teaches otherwise, that if controlled by Fabian intellectuals these institutions, upon the same foundation of injustice, would change their present regrettable characteristics-as well expect wolves to devour vegetable-marrows or grapes grow upon the deadly nightshade!

Experience has shown that when these gentlemen of intellect are in control of ministries, they function like the other creatures of circumstances. In Government departments, the acumen of the soundest business man seems to desert him. Saints forget their sacred vows and betray their dearest friends. The Foreign Office of any Government would demoralise the Archangel Michael if he were put in charge. Why should a mere superman presume?

\section{"Socialism is National Organisation." (Sir Leo Chiozza Money.)}

In the same category as the State-Socialists, obsessed with the fallacy that social evils arise from the inadequacy or inharmony of natural relations, suffering from the delusion that man by supermen must be artificially organised or improved, are the Protectionists or Tariff "Reformers." These, steadily upholding a vicious system of land tenure at home, seek by governmental prohibition or import taxes to regulate the industry and control the exchanges of their country, so, as they fancy, to benefit trade cramped by land monopoly and suffocated by domestic tariffs. They are like nurses who would give a patient drugs in lieu of fresh air and sunshine.

Also of the same distracted school of thought are the Trade Unionists, who fail to see that low wages and bad working conditions are due to the denial of the equal right of workers to the standing-place and the source of materials upon which they must labour. Their demand, therefore, for a share in the ownership and control of industry remains unsatisfied. Instead of following justice, they employ moral violence in a policy of "Devil take the hindermost." They do not see that wages fall in spite of their violence in times of bad trade, just as they rose without effort on 
their part during the Great War, when unemployment ceased.

Tepid Liberalism, decrepit and without vision, regards liberty as a state of benevolent tyranny. It asserts as rights what in themselves are wrongs. Composed of lovers of repose, the lukewarm Liberals and Democrats legislate upon the assumption that human nature is inherently defective and that there is no order or symmetry in natural law.

They take the curious view that mothers of the poorer population are naturally incompetent to feed and care for their own children; that God sends more children into the world than can be provided for ; that it is in the nature of the parents' hearts to send their children to work when they should be at play; that men and women live in overcrowded dens, work overtime in dangerous and insanitary occupations, accepting low wages, from choice. Tepid Liberalism is indistinguishable from spurious Socialism.

\section{"Walking through Dry Places, seeking Rest."}

Among the delusions occasioned by immersion in superstition, none is so tragical as that the abnormal behaviour of the aberrated captives is an indication of the depths of savagery to which they might sink if liberated.

It is this fear which is always at the back of the minds of the pseudo-Socialists, whether they call themselves Conservatives, Republicans, Liberals or Socialists. They think that civilisation is measured in terms of coercion, repression, bureaucracy and militarism, and are afraid that if the prisoners are given their liberty there will be a relapse into barbarism.

Consequently the prison walls are built higher and higher for the supposed security of "Kultur." From the right point of view, what are looked upon by the "patriots" as evidences of progress are merely retrograde movements towards absolutism, anarchy and final collapse.

Military slavery was adopted by Germany in the belief that it was possible to devise machinery which through human agency would secure for the German Government more wisdom and virtue than the people themselves possessed, that thereby national freedom would be preserved and increased. But liberty was lost to them increasingly. 


\section{FROM THE OID TO THE NEW WORLD}

Britain and America, in fighting the slaves of militarism, thought that the only way to escape the menace was to give up their own liberties in the adoption of Compulsory Military Service. Far from having preserved themselves, their national life exists upon a lower plane of health, and these nations are now living more dangerously than ever. This barbaric development is inevitable if the nations continue to walk through Dry Places.

Communities are menaced by the Industrial Trusts and Trade Unions, which hold the power of life and death over the sapless people of the cities, living in Dry Places far from the bosom of Nature. A trial of industrial slavery by the panic-stricken citizens of Rationed and Organised Famine may be stoutly advocated even by those who conscientiously resisted the Military Service Acts, but who assert that "Every individual should be compelled to fulfil some useful function in society."

"The Aristocracy of Land and Debt" have painfully organised and disciplined the complicated State upon many landlord and moneylender treadmills. With preternatural verve the "Aristocracy of Intellect" seize the obvious fact that to complete the national organisation it is only necessary to combine the many treadmills into one all-embracing National Treadmill.

It is proposed to nationalise by purchase all capital (in which they vaguely and erroneously include land), giving the sellers Government bonds in exchange. In some devious way, only known in the secret recesses of the Fabian Society, it is then intended to dissolve the bonds afterwards by means of special taxation or by simply abolishing the currency -it is a detail, and ethics need not trouble an all-highest intellect!

The State being then sole Landlord and Capitalist, men, women and children would naturally be State property. Mr. George Bernard Shaw, who will doubtless excuse our taking him seriously at his own request, thus in the language of Nietzsche shows a way out of the tangle of the National Debt: " That measure is resolute Compulsory Civil Service, called by the Trade Unionists Industrial Conscription. . . . Ruthless and thorough conscription of productive labour for all classes alike, and unsparing extirpation of the idler ; 


\section{THE PSYCHOLOGY OF CAPTIVITY}

that is the only genuine solution of the financial problem." He thinks, however, that the "Capitalists" who own the Debt will probably repudiate the Debt themselves for the return of their liberty!

Mr. Shaw, whether in serious vein or otherwise, logically takes us to the core of fraudulent Socialism. Vanity and cunning are not going to redeem the world.

\section{The Prison swept and garnished.}

It is no part of the policy of the pretentious Socialists to liberate humanity from prison. Their endeavours are limited to the sweeping and the garnishing of man's present quarters. They are really kind ladies and gentlemen who have the uplift of suffering humanity at heart within the workhouse, which is to be improved out of all knowledge and fitted with every modern convenience and luxury.

There is to be an equitable rationing system whereby population, food, clothing and housing shall be so regulated that no one shall be aware that a well organised famine is proceeding. Sexual and domestic affairs are to be arranged for us eugenically and hygienically down to the minutest detail.

We are to be obedient to orders, regimented, subordinated and disciplined from the cradle to the grave by paternal bureaucratic experts possessing the wisdom of the ages. Our characters are to be moulded according to selected and well-tested samples already prepared for the millennium by the Fabian Society.

From babyhood onwards we shall be docketed, badged and uniformed into sections, according to some function in society, predetermined by super-anthropologists and judges of heredity. Rebels, who cannot do as they are bid and labour, even though unwilling, for the good of a Collectivist Mathematical Equation, will thus be caught quite early and painlessly exterminated.

"Arty" communal kitchens, nurseries, crèches, schools, libraries, garden city barracks and so forth will be provided for the industrial conscripts, whether they like to be herded together or not.

Just as the thoughtfulness of Prussian officialdom was shown in plentiful provision of relaxation for military con- 


\section{FROM THE OLD TO THE NEW WORLD}

scripts, so that longings and vain regrets might be stilled and soothed, so likewise our Fabian Conspiracy has taken into consideration adequate instruction and amusement for those who are to lose the remaining shreds of their liberty in compulsory civil service.

Literature and Art are to be compulsorily administered in the worship of their Thing, and music and dancing are to be at Its service in the relief of the docile inmates, like doses of medicine.

To work for oneself or to co-operate with others voluntarily is Private Enterprise. This is high treason in the Capitalistic State to be founded by our modern Hedonists, who dare to accuse Nature (they do not say God) with cruelty and stupidity. They delude themselves with the belief that it is human nature to prefer slaving for an Equation to being industrious for private gain.

But just as the Trust or the Combine frowns upon the " private adventurer," so the State Monopoly of Collectivism cannot afford to have competitors starting out upon their own. They might discover by inference the extreme inefficiency of the complicated Slave System, which would be fatal to its existence.

\section{Entry of the Seven other Wicked Spirits.}

"There is one thing most certain, and that is that only by adequate preparation for war can peace in anyway be guaranteed." (Sir Douglas Haig.) So say the militarists, learning nothing from experience. They are not, of course, different psychologically from the superficial militant Socialists, who say, "The organisation of industry for peace on the same lines as it was organised for war is what we advocate."

Experience has ever shown that peace cannot be guaranteed by preparations for war, likewise when industry is organised for peace on the same lines as it was organised for war there is no guarantee that the seven other spirits more wicked of civil commotion shall not enter.

They entered upon the coercive communism of ancient Egypt. In a Red Terror they dwelt there in revolutionary France, and devoured not only the " Aristocracy of Land and Debt " but also the "Aristocracy of Intellect," children of the Revolution. 
As wisdom increases, Man yet becomes more and more impatient of captivity. The unclean spirit of Czardom returned precipitately, accompanied by the seven other spirits more wicked than himself, into Bolshevik Russia. The Communists are only the old Czarists writ large.

There is no peace for the militarists in compulsory " preparedness," and there is none in the extreme of industrial conscription, which resolves into a decomposition of reaction and ends precariously in an absolutism. The last state is invariably worse than the first.

The Great War, awe-inspiring and tremendous as it may seem, is only an incident in a fratricidal struggle caused by the retention of the barriers to man's mental and spiritual evolutionary development. It is of the Psychology of Captivity that war and civil commotion shall continue until the barricades of superstition shall be removed from the path of Justice and Liberty.

\section{"The Path on the Way to Hell is paved with Good Intentions."}

"The present position which we, the educated and wellto-do classes, occupy is that of the Old Man of the Sea, riding on the poor man's back; only, unlike the Old Man of the Sea, we are very sorry for the poor man, very sorry ; and we will do almost anything for the poor man's relief-anything but get off his back." (Leo Tolstoy.)

There is, of course, no intention on the part of the advocates of either civil or military conscription that dangerous living should be the consummation of their policies. Like the Crusaders and the coercive exponents of Kultur, their aims are good, and their attempts to hack a way through are kindly meant.

But benevolent intentions do not ensure peaceful relations. The foundation of peace is Justice, and a Co-operative Commonwealth cannot be established upon physical and moral violence. The State is not entitled to take forcibly the just reward of individual or co-operative industry, or any portion of it, in taxes. The communal revenue is Land Value Rent, which belongs of right to the whole community, no one individual having a greater right to it than another. Justice, and not Might, is Right. 


\section{FROM THE OLD TO THE NEW WORLD}

Those who think otherwise are obsessed with the degrading and abject superstition that slavery was the first condition of labour, or, deceived by appearances, imagine that the world is moving not towards Democracy, but the equal sharing of the National Slavery.

Like the astronomers before the time of Galileo, they survey the universe from the inside of a thought prison, which is no pivot for a correct sense of proportion. The true Socialism will be revealed when they learn to change their point of view, guided by Justice, open-eyed, with Mercy. 


\section{THE RULE OF THE LAND}

\section{READER'S GUIDE}

IN Chapter XVII is forecasted what may be expected to happen when the Rule of the Land is instituted. The "Irish Fair" of the present day will be replaced gradually by the New Civilisation.

\section{The Headings are :}

The "Irish Fair" of History-The Rule of the LandWhat is Taxation ?-The Futility of Quack Legislation"Are not Abana and Pharpar, Rivers of Damascus, better than all the Waters of Israel ?"-The Dead Sea Fruit of Envy, Hatred and Malice-Infamous ProposalsProperty before Humanity-" Produce More" and "Overproduction" - "Ye cannot serve God and Mammon "-Humanity before Property-Industry cannot redeem Itself whilst in Prison-Profuse Production follows Emancipation of Industry-The Effect of the Change upon the Disposition of Population-The Raising of the Standard of Life-The Emancipation of Public Enterprise-Transitional Developments-The Freedom of the Seas-" I will have Mercy and not Sacrifice"The Deflation of the National Bubble-The Abolition of Taxation. 
The Common Land is my own Land, equal with my Fellow Commoners; and our true property by the Law of Creation. It is everyone's, but not one single one's.

True Religion and undefiled is this: To make Restitution of the Earth, which hath been taken and held from the Common People. Do not all strive to enjoy the land ? The Gentry strive for land; the Clergy strive for land; the Common People strive for land; and Buying and Selling is an Art whereby People endeavour to cheat one another of the land. Now if anyone can prove from the Law of Righteousness that the land was made peculiar to him and his successively, shutting others out, he shall enjoy it freely for my part. But I affirm, it was made for all; and true Religion is to let everyone enjoy it, and you shall find rest. . . .

This is your very inward principle, $\mathrm{O}$ ye present Powers of England, you do not study how to advance Universal Love. If you did it would appear in action. . . . All this falling out and quarrelling among mankind is about the Earth, and who shall, and who shall not enjoy it, when indeed it is the portion of everyone, and ought not to be striven for, nor bought, nor sold, whereby some are hedged in and others are hedged out. Far better not to have a body than to be debarred the fruit of the Earth to feed and clothe it. And if everyone did but quietly enjoy the Earth for food and raiment there would be no wars, prisons nor gallows.-Winstanley (I650). 


\section{CHAPTER XVII}

\section{THE RULE OF THE LAND}

\section{The "Irish Fair" of History.}

This passing epoch of physical and moral violence may be likened to the disorderly conditions in a thoroughfare, where the ignorant wayfarers, who do not know that they are ignorant, move about anyhow and anywhere without intelligent consideration for each other. "Unions of strength" form in the hostile environment for the purpose of hacking a way through the rabble, and these contend with each other for "Freedom of the Road."

So long as men in the street remain unenlightened as regards the Rule of the Road, "freedom" will have to be fought for. In like manner, anarchy, manifested in the friction and the quarrelling among mankind about the Earth and its fruits, is due to our failure to observe the Rule of the Land. Until we learn to conform to this application of the Golden Rule, "freedom" will have to be fought for, and millions will continue to perish by war, pestilence and famine.

\section{The Rule of the Land.}

The economic rent of land is the rate by which individuals measure the desirability of living within the jurisdiction of any community or nation. In districts remote from society, where there is no social service or government, solitary individuals live rent free. The difference between the social value of living in solitude and the value of living in society manifests itself in site value, which is the measure of government.

Security of tenure is essential for the encouragement of private enterprise and the conservation of property which individuals are justly entitled to, and there is no security of tenure so long as ground rent finds its way into private pockets. The Rule of the Land is that the economic rent, 


\section{FROM THE OLD TO THE NEW WORLD}

which is common property, should be aggregated into a balancing or common fund and returned in equal portions to all members of the society or nation in some suitable way, as, for example, by being devoted to common needs as determined at any time by the whole people themselves, thus encouraging public enterprise.

Until the common right to the earth is asserted by the taking of the public rent by the people, abolishing for ever the power of individuals to buy and sell site value, it is inevitable that citizens will continue to be robbed by private and public banditti of what is private property. Private and public enterprise will also continue to be discouraged, and experience has abundantly demonstrated that until we conform with the Natural Law of Equity, with regard to land tenure, there is no escape from niggardly production and unfair exchange.

\section{What is Taxation ?}

Mr. James R. Brown, an American writer, succinctly describes our present unscientific system of collecting municipal revenue :

"Taxation is the collection of payment for public services. By public services we mean streets, sewers, lights, police, schools, etc. Public services should be paid for as all other services are paid for, that is, according to the value of the said services. The value of your house, furniture, garage, auto, etc., is not and cannot be the measure of the value of the public services you have enjoyed. To tax a man on the value of his house as payment for public services is just like charging a man for a suit of clothes by the value of his auto. Taxing a man on the value of private services is simply taking private property for public use without compensation-in other words, stealing by due process of law.

"When a man builds, paints or improves his house, he pays for those services to the painter or the builder. Why, then, should he be called upon to pay for those services a second time to the town that did not build or paint-in fact, rendered no service, and delivered no goods? To increase a man's assessment, merely because he rendered a private service unto himself and, incidentally, to the public through improve- 
ment to the neighbourhood, is, to say the least, unreasonable.

"If your butcher, going past your door and noticing that you had painted or improved your house, went back to his shop and sent you a bill for twenty pounds of steak that he had not delivered, and did not intend to deliver, you would say that he was both a fool and a crook. Then, in the name of common sense, why should the town do a like foolish and dishonest thing?"

Nothing in our relationship with each other is of such far-reaching importance as taxation, or the collection of public revenue. It is the means whereby the door of opportunity is opened or closed, yet we persist by means of taxation in choking industry, and by omission to collect what by right belongs to the community we place a premium upon idleness.

The prevailing concept we now have of the vital functions of taxation is that, requiring a certain amount of revenue, we, the State, should go out and seize it wherever it may be conveniently confiscated. There is a total disregard of the consideration of services rendered or of value received. Consequently, the State is at present merely a device enabling one section of the community to live upon the rest.

We have not deliberately committed this folly, but have drifted into a false position through ignorance of the fact that the so-called value of land is the measure of public services or government. Through omission to turn this value from private into public channels, by adjusting the incidence of taxation, we have given some the power to close the door of opportunity against others.

But it is decreed that in depriving our neighbour we inevitably deprive ourselves in due time. Nature abhors unequal opportunity, and we must live and let live. Given equal opportunity to the resources of Nature, wages, rents and prices would right themselves. There would be profuse production and loafers would no longer be enabled parasitically to live upon labourers.

\section{The Futility of Quack Legislation.}

Attempts to set matters right by quack legislation are comparable with the futile actions of people residing in a 


\section{FROM THE OLD TO THE NEW WORLD}

building the foundations of which have dangerously subsided. The subsidence may have been imperceptible at the commencement, but the house leans over so far now that the maladjustment can be denied no longer.

Instead of courageously facing the situation and carrying out a real reform, which daily becomes more urgent, the ill-informed occupiers waste precious time quarrelling with each other about symptomatic obliquities. They discuss the necessity of putting the pictures straight upon the wall and disagree about the means to be taken to prevent the furniture sliding along the floor.

Finding themselves "overpopulated" against one side of the house, owing to the slope of the floor, those crushed near the wall blame their neighbours whose weight they feel, whilst the "oppressors" peevishly curse the inconvenient struggles of the "much too many" for power. All the occupiers are consumed with fear and hatred; all are unhappy within the doomed structure, threatened with the periodic and increasing frenzies of the revolving factions.

\section{"Are not Abana and Pharpar, Rivers of Damascus, better than all the Waters of Israel ?"}

Like leprous Naaman the Syrian, the quack legislators imagine that the terrible nature of our social disorders calls for something "much more effective" than conformation with the Golden Rule. They wish to be bid to do some great thing, and would " nationalise," by one magnificent financial operation, land and " the means of production," regimenting the workers under Commissions of Experts. For our social leprosy the inauguration of the Rule of the Land, which is square justice, seems too simple a remedy.

Yet in advocating glittering schemes of spurious Socialism these false prophets say the adoption of the Rule of the Land is impossible of realisation, because so many difficulties are in the way. The contentions of the quack legislators are thus mutually destructive. Beware of false prophets!

The remedy, like all real remedies, is a simple one. The difficulty lies in clearing away superstition. We see what we know.

Legislation is at any time the reflection of the common credence of a people, and education must precede legislation. 
We must learn that Justice with Mercy-compassionate relief in the few cases of temporary hardship arising when the community resumes possession of its property-is the only way to dissolve conditions promoting fear and hatred.

\section{The Dead Sea Fruit of Envy, Hatred and Malice.}

So long as men and women believe that evil can overcome evil, and upon this moral violence base legislation, then bitter disappointment is bound to follow their enactments.

In Great Britain, in I920, after a Peace of Vengeance, it was sullenly conceded that the Germans, who were said to be the real debtors, could not pay holders of Victory and Joy Loans without "dumping" commodities into the country, thus spoiling the market for the national profiteers.

The wolves of discord, who shrieked formerly at the thought of "Peace by Negotiation" and "open covenants openly arrived at," which would have preserved thousands of valuable lives, and which would have resulted in the National Debt being half what it eventually became, now turned their savage attention to other mischief. The superstitious idolaters of "Capital" said that the high prices were due to inflated wages, and they came into conflict with votaries of the rival deity "Labour," who contended that since burglars are put into prison for robbery, profiteers should be, at least, heavily fined.

The world being more unsafe for democracy than before the war, a greater army and navy establishment was needed to keep order. Bureaucracy had presented the nation with several new broods of Civil Service tax-eaters, whose nourishment cost more than twice the pre-war imperial taxation. Although Germany as a supposed debtor was inconvenient, this was no reason why " the marauders at the rear " should have adopted as their debtors, instead, those who had already paid for the war in blood and labour, and call upon them to pay a second time with "interest."

It is not less remarkable to have to record that, possibly under the hypnotic influence of the usurers, this cool assumption should have been accepted "lying down." This hypnotism, if it did exist, must have been confirmed by the Fabian demagogues, who took the curious view that the landlords and idle-rich monopolists paid taxes, thus paying 


\section{FROM THE OLD TO THE NEW WORLD}

"interest" themselves upon the money they had so trustfully lent in the belief that the Germans would repay them!

\section{Infamous Proposals.}

As in ancient Egypt, like Joseph, the Chancellor of the Exchequer was deputed to tell the unfortunate people what to do in order to escape from financial disaster. Redemption necessitated the payment of fourteen hundred millions of pounds sterling per annum, or seven times pre-war imperial tribute. The Government must have new sources of "income."

"Divide and rule" is a maxim as well understood by modern Cabinet Ministers as by defunct Roman patricians. So occupied in mutual hatred were the factions that they fell easy victims of a colossal confidence trick. The Government had to find money somehow. So it was said.

The querulous newspapers, that complained of municipal rates, for which there was some return, if only to ground landlords, did not ask what value was received by the community for this heavy burden of imperial taxation. Not one inquired if the country had been at war with the right people, considering that it had been victorious!

The kill-joys found gratification in the increased taxes upon innocent amusements and harmless luxuries. Those who considered that the poor should contribute more out of bedraggled poverty had grim satisfaction in the imposition of increased "breakfast-table duties." The demagogues, in increased taxes upon incomes, thought they saw one step nearer their millennium of universal poverty. "Labour" noted with premature glee the wriggles of the Federation of British Industries, which weakly protested against the excess profits duties. What was the alternative? Would the manufacturers prefer a capital levy?

Evil cannot overcome evil. Labour, which had desired to see the profiteers in prison, was already there, its prison ration about to be reduced further. Robbery cannot overcome robbery.

In the hostile environment, Capital did the only thing it could. The Chancellor had said in effect, "It is plain what you must do. We, the State, have arranged that certain imports may only come into the country on licence, 
and there are import duties and embargoes upon other things. You are thus protected from foreign competition. Combine into Trusts; raise prices, and you will be able to pass your taxes on to the consumer, and more. New competitors at home, having to pay much higher prices for buildings, plant and machinery, will be at a disadvantage, and they will be delivered into your hands. Free from internal competition, you can exploit the public to the fullest extent. The condition is that for every $f_{\text {Ioo }}$ of excess plunder you must hand over to us, the State, $£ 60$, retaining $£ 40$ for yourselves."

Not only did the prices of commodities soar, but their quality suffered. The demagogues, who had joyfully hailed the taxation " according to ability to pay," attributed the poor quality of the goods to the fact that the wicked manufacturers "made for profit and not for use."

To the landlords, who had no excess profits duty to hand over, the Chancellor of the Exchequer was very tender. He repealed even the absurd so-called Land Duties, which a predecessor had employed as a "red herring" some ten years before to deflect the attention of the electorate from genuine "rare and refreshing fruit." One million pounds collected as land duty was returned to these privileged persons of "property" as balm for outraged feelings.

The Chancellor in effect said to the landlords, "You have now complete control, because your power to withhold land from use is supreme. Land required for buildings, houses, quarries, mines and docks can be sold at the highest possible price, when you are graciously pleased to sell portions, or it may be leased at inflated ground rents with onerous terms to tenants.

"Since farmers do not pay excess profits duty, and the price of corn is maintained by subsidies from taxes paid by the manufacturers and others, through the operation of the Corn Production Acts, which are in reality Rent Production Acts, it is obvious that there is a future of great prosperity for the landed interests. But there is an obligation to us, the State, for our protection. Of the toll you exact from the tenants of the land you must hand over, according to ability to pay, $£ 30, £ 50$ or $£ 75$ of each $£$ roo collected, retaining the remainder for yourselves." 


\section{FROM THE OLD TO THE NEW WORLD}

"The landed interest" thereupon took refuge from the questionable attentions of their "friend," and closed the door to Nature's storehouse closer behind them-so closely that soon there were no "excess profits" for manufacturers. ${ }^{x}$

Portions of their large estates were sold at high prices to sitting tenants and others who had "done well" during the war period. There was, of course, no tax upon the profits of such sales. The new landlords, well endowed by war prosperity, had taken the precaution to purchase large blocks of Victory tax-free Bonds, and the vendor landlords followed their example in investing the proceeds of land sales.

The one-time farmers became independent gentlemen like the old landlords and lived upon the proceeds of national usury. The farms were converted into pleasure grounds, and only a few of the farm labourers were retained to keep the fences in order or as gamekeepers.

Unscientific taxation had simply choked industry, and omission to collect what by right belonged to the community had placed a premium upon idleness. The country became less self-supporting, because more land fell out of cultivation in order that the tax upon production might be escaped. Buildings and other improvements fell into disrepair and were not renewed, in order to keep the rating assessment low. Prices went up, and wages went down.

\section{Property before Humanity.}

It was thus that the Government redeemed their promise made during the Great War in the words, "A grateful country will never forget you." The claims of the soldiers, sailors and workers who "fought for their country" were ignored, or were obscured by unsatisfactory measures of mendacity. The National Debt, to those who had tried to save the nation from the consequences of national folly, was perverted into a false debt of eight thousand million pounds at "interest" to bondholders who had profited during the war.

The so-called "National Debt" rests upon the insecurity

x The Excess Profits Duty was abolished in 1920 because upon the basis of the three years' average the Treasury had to refund more than it received in revenue. It was replaced by the Corporation Profits Tax. The Corn Production Acts were repealed and their attendant obligations repudiated by a bankrupt Treasury in I92I. 
of a superstition that while human life may be conscripted for the shambles, blood-money is Sacred. ${ }^{x}$

\section{"Produce More" and "Overproduction."}

In ancient Egypt the taskmasters called upon the toiling slaves to make bricks without straw. To-day (I9I9) " Produce more" is the cry of quack legislators and the holders of "Liberty Bonds." How, in the name of all that is reasonable, can the labourers produce generously, when the source of wealth is possessed by the few, who profit according to their powers of obstruction? How can the nation redeem itself while incarcerated in a debtors' prison?

When a housebreaker is caught, he is punished once for his offence, but the builder, the clothier and the purveyor of necessities are punished perpetually. What encouragement is there for industry when it is treated as a criminal offence against the community?

The hollow minds echoing "Produce more" to-day will be reverberating "Overproduction" to-morrow (I92I), as the morass of poverty creeps in upon the people, clambering high upon each other's backs. Farmers, manufacturers and captains of industry, who declaim against high wages, discover eventually that their existence depends upon purchasing power being well distributed throughout the population.

A millionaire cannot consume more bread than a mechanic, and a duchess cannot eat more pickles than a washerwoman!

Seeing the monopolist waxing fat upon the extreme necessities of his fellows, undergrown minds, obsessed with the narrow mania of owning things, imagine that for exchange to be profitable the seller must get from the buyer a greater measure of value of services than he gives in return. In fair exchange, which is the only profitable exchange, there is a bargain for every party. Fair exchange is no robbery.

In fair exchange, competition is manifested in cordial co-operation to serve consumers, who feel themselves bound to reciprocate. But when production and exchange are made the vehicles of taxation, producers are handicapped, and competition is a selfish scramble in which everyone is for himself or herself. Some get something for nothing,

I Approximately $t^{\text {ro, } 000}$ was expended by the belligerent governments per man killed. 


\section{FROM THE OLD TO THE NEW WORLD}

while inevitably others get nothing for something. Hell is let loose, and the haves call in the police and the military to rescue them from the fury of the have-nots.

Instead of "a land fit for heroes to live in" of peace, plenty and happiness, there is, in a beautiful, fertile country full of natural resources, a terrible struggle for existence in which the weakest go to the wall and the strongest do not survive. Infant mortality increases, deaths from starvation, disease, immorality, despair, murder and the gallows swell the "wave of crime."

Labour, without vision, Lazarus-like, pleads for crumbs from the rich man's table, or " the endowment of motherhood by the State." It is appropriate that among their harmless May Day resolutions should be included one in favour of " the institution of State support for the blind." Is not every child endowed with an equal inalienable right to its Motherland? Why not resume possession of the common inheritance, if only for the sake of the children?

There would then be no need for the unions to restrict their numbers, for the members to restrict output and refuse admission of ex-service men into industrial trades. It is the dread of unemployment and attendant depressed wages that causes them to act in this way.

But Labour has not seen the easy solution, and the leaders are blind leaders of the blind. Upon the erroneous assumption that profiteering can overcome profiteering, the Unions combine against the trusts and try to raise wages by force or " control " industry by " direct action." They go on strike " to reduce the cost of living." Alas, for Dead Sea fruit !

\section{"Ye cannot serve God and Mammon."}

Neither Capital nor Labour appears to know what it wants, and each gets what it cares for least. The labourers in the temple of Capital advocate freedom for private enterprise and choke private enterprise by Trusts. Trying also to serve God and Mammon, the labourers in the rival denomination of Labour demand freedom, and condemn private enterprise because they associate private enterprise with the Trusts.

As in a trance, following a glittering mirage of superstition, Capital and Labour are combining, without know- 
ing what they do, in the setting up of a super-trust, in which there will be "discipline-iron discipline for all." It is the rigidity that precedes an orgy of "Bolshevism."

The folly is called "Socialism," and such measure as we now suffer is the origin of all our calamities of niggardly production and unfair exchange. In spurious Socialism, which is a denial of the natural right of men and women to themselves and the reward of their labour, do we find the origin of class hatred and strife.

\section{Humanity before Property.}

"Property in land, like property in slaves, is essentially different from property in things that are the result of labour. Rob a man or a people of money, or goods or cattle, and the robbery is finished there and then. The lapse of time does not, indeed, change wrong into right, but it obliterates the effects of the deed. That is done; it is over; and, unless it be very soon righted, it glides into the past, with the men who were parties to it, so swiftly that nothing save omniscience can trace its effects; and in attempting to right it we should be in danger of doing fresh wrong. The past is for ever beyond us. We can neither punish nor recompense the dead. But rob a people of the land on which they must live and the robbery is continuous. It is a fresh robbery every succeeding generation -a new robbery every year and every day; it is like the robbery which condemns to slavery the children of the slave. To apply to it the Statute of Limitations, to acknowledge for it the title of prescription, is not to condone the past; it is to legalise robbery in the present, to justify it in the future." (Henry George.)

Failing to differentiate, Capital has attempted to establish sacred rights of the individual to that which is everyone's but not one single one's. It has thereby tended to obscure the sacred right of the individual to his or her own property. Labour in similar confusion has tried to abolish private property in things that are the result of labour, and is stricken with chronic poverty because it is a party to robbery.

The labourers of the denomination Capital, like those of Labour, are heavily mortgaged in national, municipal 


\section{FROM THE OLD TO THE NEW WORLD}

and business debts to the usurious financiers. They are sinking continually and increasingly into the surrounding morass of poverty, because of their superstition, and the moneylenders on their backs go with them. Liberty Bonds, Land and Housing Bonds condemn to slavery the children of the slave. Those who enslave are themselves slaves. We must live and let live.

Unions of Labour, Trusts of Capital, Leagues of Nations, instituted for the purpose of "controlling" wages, prices and peoples, are impotent, inasmuch as they fail to conform with Natural Law. They attempt to build a dam of Power and Might against the operation of economic and moral laws. The pressure of necessity accumulates against their little propositions, and the God-Nature disposes that they shall be swept away in catastrophic chaos.

If we would avoid complete disaster, we must open the sluices. Is this remedy too simple? There is no other!

When humanity is placed before property, the sacred rights of humanity are respected. The earnings of the labourer are not then confiscated by means of compulsory taxes upon industry. The State or society of individuals collects its own property, which is the economic rent of land, a communal value separate from the wages of individuals or the prices of commodities.

Privilege gives way to equality of opportunity, and the bodies of men, women and children are not violated, nor their souls destroyed. The sacred right of individuals to themselves is apparent when the common right to the earth is asserted.

"Moral duty consists in the observance of those rules of conduct which contribute to the welfare of society, and by implication of the individuals who compose it.

"The end of society is peace and mutual protection, so that the individual may reach the fullest and highest life attainable by man. The rules of conduct by which this end is to be attained are discoverable-like the other so-called laws of Nature-by observation and experiment, and only in that way." (Huxley.)

\section{Industry cannot redeem Itself whilst in Prison.}

The lessons of the past have surely been severe enough to expose the folly of that quack legislation which would 
pile up heavier debt for the robbery of posterity. Give the labourers of mind and brawn room to work in and materials to work upon, and they would soon divest themselves of the loafers now being carried upon their backs. Work would become so pleasurable that no man or woman would be idle. They would work as children play, and no compulsion would be necessary.

It is a fact of common observation that persons who have been for a long period in prison lose in some measure the desire for freedom, especially if they have passed middle age, When the debtors' prisons were abolished in England, some of the poor old prisoners had almost to be driven away. Others came back after a while and asked if they might linger in the cage for the sake of old times. The delights of freedom soon, however, superseded this unnatural shyness in freer surroundings, and they were seen no more by their late keepers.

This psychological curiosity may explain why the senile "Aristocracy of Intellect" and the leaders of Labour, whose desire to replace the existing keepers is notorious, wish to remain in prison, and why they oppose so fiercely a policy which would open the sluice-gates of freedom. Many of them know that, given economic freedom, the labourer will be independent, able to walk upright, fearing no man.

The institution of the Rule of the Land does not mean that the present useful occupiers of land will be disturbed, but on the contrary that their discomforts will be dissipated and their title to real private property strengthened. The abolition of taxes upon improvements means the restoration of property to its owner.

No one retains land, not using it and paying rent for it. Unwanted land is relinquished after a short period, when to retain it is a burden. It follows, therefore, that when the Rule of the Land is in operation the source of wealth will be made available to everyone on equal terms. The weak will no longer be handicapped in favour of the strong.

\section{Profuse Production follows Emancipation of Industry.}

The readers of former chapters will have no difficulty in visualising the effect of the change. After an Appointed 


\section{FROM THE OLD TO THE NEW WORLD}

Day upon which the rent of our estate is demanded, the activities awakened will resemble those occasioned at the outbreak of a great war, except that it will be a joyous jubilee and not a feverish display of forced optimism. It will be as though a great weight were removed from the springs of industry. A few persons may continue for a while to have misgivings, but as the benefits appear, they will be reconciled and won over.

There will be a great and increasing demand for labour, and no one willing and able to work will be unemployed. So much requires to be done that is scotched in the present circumstances. There will be an enormous demand for the services of every farmer, engineer, builder, manufacturer of every kind, shipper, transporter, miner, quarryman, textile worker, shopkeeper and artisan. Teachers and instructors will be at a premium. Those who are performing work for which they have no aptitude will have opportunities from which to make a selection.

The rent of the land being available for public services, taxes upon improvements, such as buildings and machinery, should be repealed first of all. The municipalities need money badly, and as their claim is a premier one, allocations to the local governing bodies according to population or other essential factors will replace generously the niggardly sums obtained by penal taxation imposed upon private property. Herein lies the solution to the problem of the equalisation of the rates.

With the hostile tariff removed from the building industry, the housing problem will find a real solution, because not only will sites become available, but raw materials for the houses also. The slums will melt away, and valuable sites for business premises will be opened up. The pressing needs of education as regards schools and colleges will at last find satisfaction.

\section{The Effect of the Change upon the Disposition of Population.}

The fundamental change in the incidence of taxation will have the effect of abolishing the invisible barrier of high-priced way-leave surrounding towns and villages and preventing their natural expansion. Land which should 
have houses and market gardens upon it will no longer be held up by some speculator growing grass at the best, and weeds and corruption at the worst. The speculator will be impelled either to convert himself into a useful member of society by building houses or growing crops intensively for the good adjacent market or in some way associating himself with legitimate public and private enterprise.

The great demand for labour and services will lead to the emancipation of the labourer of every degree. Wages and salaries and profits will rise to a natural level. There will be neither excess nor shortage. Everyone will get what he fairly earns, and no one will get more than he fairly earns, consequently there will be neither colossal fortunes nor underpaid merit. The deadly fear of poverty, said to be the only hell the Englishman fears, will cease to exist.

The unprofitable striving for illimitable wealth, which brings hollow misery upon family life and which the accredited possessor least of anyone ever enjoys, will cease to mock departed youth. Loafers will be met with poverty as a consequence, but they will have every encouragement to be industrious and there will be no premium upon idleness.

State doles and bottles of medicine, sham housing schemes and pauperising quackeries in general will disappear, because they will be no longer necessary. Invalids, suffering from lack of fresh air and sunshine, when liberated from captivity will take up their beds and walk. The crutches and ambulances of compulsory communism, called "Protection," "Unis" and what not, will be thrown upon the scrap-heap, because they will be redundant in the New World of free production.

The old world is a battle-field !

Private and public enterprise are together quite competent to attend to their own particular fields, when the fences of vested interest are removed. The amiable amateur with Fabian theories and the flotsam and jetsam of the commercial world, who now compose a central bureaucracy and who pretend to control municipalities and private businesses, will be left high and dry.

Every citizen will be impelled to take an absorbing interest not only in his own private vocation, but also in 


\section{FROM THE OLD TO THE NEW WORLD}

the affairs of the community, because the issues will be no longer obscure. A warm spirit of patriotism will be recreated, not transitory and false, like the feeling aroused during war-time, but strong, genuine and lasting. Comradeship and goodfellowship will take the place of snobbery and hatred. Strikes will be unheard of

\section{The Raising of the Standard of Life.}

The congested, petrified population will begin to move and grow out naturally. Those living on the outskirts of great towns, wishing to move further out, will be able to find sites, because the "dog in the manger" will be gone. They will make room for those whose ambition it is to move from the overcrowded centres to the suburbs. Petrified population will begin to spring into new life. The sap will flow into the dry channels of the race, and the $\mathrm{C}_{3}$ community of the Old World will be replaced by the AI citizens of the New.

It is compulsory communism that builds barracks, and private enterprise that builds pretty and useful homes. Will not builders, with free access to the land and left to themselves, design and erect, for themselves and others, houses to suit the artistic tastes and utilitarian requirements of each occupier? Convenience will be placed before cost, because there will be room for it, and purchasing power will only be limited by the expanding standard of living. Improvements will not be savagely fined, and the mildew will disappear from the landscape.

The yeomen of old England will be born again of the ground-down helots of agriculture when emancipation comes. They will bring the barren country-side into cultivation and have no dread that they can be robbed of the fruits of their industry. Garden cities and villages will be dotted richly throughout what are now deserted square miles of countryside, when population is permitted to dispose itself naturally.

Emulation in the raising of the standard of living for all will substitute the shabby competition of "doing without " for the many that the few may riot in extravagance. Monstrosities of all kinds, which we now shut our eyes to, or try to cover up with charity, or attribute to the niggardliness of Nature, will seem like half-forgotten nightmares. 
The Will to Life will inaugurate the Co-operative Commonwealth-the advent of Real Socialism founded upon Justice, the exodus of the False Socialism based upon wrong and robbery.

\section{The Emancipation of Public Enterprise.}

Public enterprise will be regulated as private enterprise will be regulated, namely, by the payment into the common fund of economic rent for the land occupied by public undertakings. I Way-leaves for circulatory services, freed from the obstruction of privilege, will be obtained with the same facility as sites for the activities of private enterprise. It will not be possible for selfish individuals to hold up much-needed public improvements, but reasonable compensation will be agreed to when individuals find that they only penalise themselves by inert tactics.

Pressing problems relating to motor, rail and common street and road services, the provision of water, gas and electricity supplies, and the disposal of sewage, will at last be freely solved. On the same terms as private enterprise, there will be no monopolies. When there is simple economic justice there will be no private or bureaucratic concessions for the exploitation of the consumer. Public opinion will be keenly interested in public affairs and the Government servants will not be allowed to become public masters.

\section{Transitional Developments.}

Such a change as we have outlined will not take place violently; rising from the roots upwards, a new fresh growth will spring, and some of the old wood will remain dry and sapless. There will be a natural evolutionary metamorphosis. The obsolete shell of the Old will gradually crumble away and be assimilated into the young economy of the New World.

Instead of matters going from bad to worse, as at present, there will be a series of developments ever leading to better conditions. During the transitional period, static minds, learning nothing and forgetting nothing, will receive many wholesome shocks, which, if they do no good, will do no harm.

$\times$ A book entry in the case of national undertakings. 


\section{FROM THE OLD TO THE NEW WORLD}

They will see, with feeling akin to dismay, miners, agricultural labourers, chemical workers in dangerous occupations, common sweeps, scavengers and other heroes command such good wages that they can obtain all the necessities of life, give their children a liberal education, do without health insurance, and laugh at the idea of old age pensions from the State. To the muddle-headed "experts" it will seem extraordinary that school-teachers, tutors, draughtsmen and clerks will suffer no longer from chronic underpayment.

Their impulse may be to secure Acts of Parliament for the limitation of wages, salaries, profits and incomes. They must be gently humoured until their reason returns. If they are unable to learn that any interference with the free play of economic forces leads to disaster for them as for others, they cannot hope to be taken seriously in the golden break of freedom.

After an Appointed Day, the bishop ${ }^{\mathrm{I}}$ who once said, "The housing question has always been a difficulty; it was so on the first Christmas morning, when Joseph could not find a room in the inn. But it will finish in Heaven, 'In My Father's house are many mansions.' You who are inconvenienced here will not be inconvenienced there" -if happily he be alive-may be scandalised when the overcrowded and houseless provide themselves with mansions, instead of waiting until a merciful death overtakes them.

Habits of mind acquired in the Old World will persist for a while into the New, but it will not be long before saner and fitter thought prevails. It will be discovered that men and women do not work well in workhouses and that inefficiency attaches to unwieldy businesses. The growth of village industries, in which labourers co-operate as partners, will supersede the industrial slavery of the Trusts.

Real scientific management will substitute the unscientific task system. Expert loafers with stop-watches will find more attractive employment. There will be no masters holding the power of life and death, but leaders chosen with unanimity because they merit such recognition.

I Bishop Taylor-Smith, Chaplain-General, at a war memorial unveiling at Guildford, March I920. 
In industrial and domestic affairs, labour-saving methods and appliances will be eagerly adopted, and unpleasant occupations will be abolished by the liberated application of inventive skill, richly encouraged by a reward, which will not be stolen. Humanity will be placed before property because it will pay, and the labourer will be no longer a slave to some machine of his own creation.

In the Old World, when production exceeds purchasing power of unrequited labour, there is unemployment and distress for the wage slave and the employer, but in the New World of profuse production, "overproduction" will simply mean shorter hours of toil and more time for humanity to devote to physical and mental improvement.

Economic freedom, associated with wealth, health, security and leisure, is the sorely needed foundation for the Higher Endeavour of the human race. This endeavour is directed by the Intelligence impressed and manifested in us, but there is low mental visibility owing to superstitions in the atmosphere of the Old World. We shall begin to see clearly in the New World, and understand what now is unaccountable.

\section{The Freedom of the Seas.}

Free production will make free trade between countries an obvious concomitant. Traders, realising that salaries and profits fall into the category of wages, will no longer talk of reducing wages in order to reduce the cost of production to meet foreign competition. Free exchange will be welcomed by free men as the handmaid of free production in reducing the cost of living for everyone.

Example is better than precept; therefore, in adopting the Rule of the Land, enlightened nations by their fruits will induce backward nations to follow. What militarism has signally failed to do, righteous dealing will do without effort. The Assertion of the Common Right is the True Internationale, and it leads inevitably to the universal adoption of the Open Door. Custom-houses will disappear as obsolete institutions and the foolish jealousies of nations will be forgotten.

There is no natural monopoly in overseas exchange, any more than in exchange overland. The high seas 


\section{FROM THE OLD TO THE NEW WORLD}

are the great international commons of the wide world. Monopolies in shipping only arise at present because fresh ventures are discouraged by custom duties and other unscientific taxation on shore. This unfairness is accentuated by Government concessions and by subsidies paid out of the national till upon various pretexts to established shipping lines.

Trade channels are furthermore narrowed when, in the hostile environment of penal taxation, the railway interests combine with the shipping companies to set up toll-gates upon land and ocean for the concerted plunder of the producer, trader and consumer.

Each national carrying system is backed up by its national taxpayer, who is bled while boasting of " our" mercantile marine. While busy paying custom dues out of one pocket, the other pocket is picked by the profiteer shipping company!

What is extorted by fraud must be defended by force against the rival predatory systems of other countries. Monopoly carries fire-arms because it is living dangerously. The "patriotic" national, threatened by a possible famine blockade, is therefore glad to be mulcted in taxes for the support of " a glorious navy to uphold the freedom of the seas." Tribute for this purpose exceeds the dividends paid out by the shipping trusts.

The world is made unsafe for democracy. Trade and Customs Commissions reveal in their reports how a miserable carrying trade in, say, the Pacific Islands, thousands of miles away, may be the bone of contention between rival shipping rings of different nationality, and the quarrel sow seeds of hatred for a harvest of madness to be reaped in a future world war.

Such is the unprofitable overseas commerce of the Old World of niggardly production and unfair exchange.

The adoption of the Rule of the Land heralds the advent of the real Freedom of the Seas.

When the land monopoly is abolished by the calling up notice asking all holders of land, used or unused, to pay rent to be devoted to the common needs, and improvements upon the land are exempted from taxation, railways, docks and shipyards will be multiplied. The wiredrawn 
stream of commerce will grow into a generous flow of activity, and with the vanished shortage of ships' bottoms will disappear the shipping trusts.

Passengers, owing to the beneficial competition to give them service, will obtain berths and courteous attention. Merchandise will find space at reasonable terms. Upon equal terms, the Trust giant is no match for private enterprise. Bands of slaves cannot succeed against the co-operation of free men; consequently, in accordance with Nature's fiat, there will be an assimilation of co-operative independence and a dissimilation of predatory combination because it will not pay.

Just as walled cities have become interesting archæological curiosities, so the apparently indispensable armaments and navies will become objects of mild surprise in the New World of free production and free exchange.

Instead of each nation imagining that it can make the world safe for democracy by making it unsafe for all others, there will arise a universal Entente Cordiale, which is better than Leagues of Pickpockets, scraps-of-paper Treaties and Secret Agreements of Diplomatists.

\section{"I will have Mercy and not Sacrifice."}

If the sluice-gates are opened in time and the Rule of the Land is put into operation, the community will magnanimously look upon the past sins of individuals as the outcome of maladjustments for which, due to superstition, all are responsible.

Compensation to those who have been living rent free, or who have been receiving tribute from the industrious for the use of the earth, cannot be entertained. Indeed, the land has been redeemed in blood and labour many times over, and its restitution will bring compensation not only to those hitherto deprived of their birthright, but also to those now superstitiously believed to have some peculiar right to it.

The great majority of landlords are, as labourers, suffering severely from the effects of the present evil system, and all will gain immeasurable happiness in the absence around them of fellow-creatures struggling in poverty, disease, vice and misery. It is impossible to realise 
adequately to what great extent we are affected by the misfortunes of our fellows, misfortunes which cannot be remedied by charity, but only by justice.

When men were called up for sacrifice during the Great War to save the land, there were tribunals set up for the relief of dependents. The cases of bitter hardship they sat upon were many, and the quality of mercy was very strained.

But there will be no sacrifice when the land is mercifully conscripted to save the men. A tribunal will have cases few and far between of genuine hardship to consider, and mercy will be overflowing from a grateful community.

\section{The Deflation of the National Bubble.}

If the sluice-gates are opened in time and the labourers are liberated from the prison of land monopoly and given access to the Source of Wealth, they will free themselves from mortgages like national debts, and they will own the stocks and shares of industrial undertakings themselves.

In the last analysis, debts can only be repaid in goods, and if Great Britain, for example, can produce more than eight thousand millions of pounds sterling worth of ills during five years of war, the nation can produce an equivalent surplus of goods during a similar period of peace, given the opportunity. National debts will not long survive the abolition of the system from which they spring.

While there is an ethical principle involved which precludes any "buying back" of the land, that may not be bought and sold, there is none in the redemption of the folly known as the National Debt. If a "capital" levy, reduction of interest, or other partial repudiation is equitable, then a complete repudiation or cancellation is just.

In any case, the monstrous arrangements of a past generation of men are not binding by any rule of equity upon future generations. The grandson of a creditor cannot reasonably expect repayment of a loan from the grandson of a debtor.

There is, however, a danger of doing fresh wrong by repudiating a national or other debt, if carried out during the generation in which it is created, unless a unanimous 
call be made for cancellation. It is safer to repay, and it can be quickly repaid if the Rule of the Land is adopted. Violence defeats its own object.

When justice is done, there will be no private property in persons or in our Mother Earth. True wealth, the product of labour applied to land, constantly tends to waste away. Labourers will determine the production of wealth to any amount, consequently a promissory note or bond will command service for value received, but carry no power to enslave. While small bondholders may benefit by an immediate repayment, the large financiers will get a "white elephant." They will be so embarrassed by perishable wealth that they will ask for relief from superabundance!

Curses have a way of turning into blessings when justice is done.

\section{The Abolition of Taxation.}

After the Appointed Day in which the community enters the New World, there will be two distinct developments in taxation.

One development will be that valuable land, possessing high potential rent and at present under-used or unused, will be taken up and used to the fullest extent according to its location. The result will be that although land now in use will lose its speculative value and pay a rent truly economic, the Common Fund in the aggregate, as population disposes itself symmetrically, will increase rapidly. It will enormously exceed the "hut" tax or tax upon improvements imposed at the present day by the local authorities and municipalities, which will be the first tax to be abolished when ground rent is taken by the community.

The other development will be that, production of houses, food, raiment and all commodities being stimulated through land being forced into use, there will be a disappearance of poverty on the one hand and rich loafing on the other. Associated with these symptoms, vice, crime, violence and disease will succumb also. The heavy charges for the provision of poor relief, workhouses, prisons, reformatories, asylums, labour exchanges, and a multitude of palliative establishments, will diminish towards zero. 


\section{FROM THE OLD TO THE NEW WORLD}

Not only will ordinary unemployment cease, but thousands of Civil Service officials, now doing what is really useless work and a charge upon industry, will become wealth producers. The central administration will be curtailed, and bureaucrats, surrounded with opportunities of making a lucrative honest living, will be glad to quit ministries, as and when they become uncomfortable in their present quarters, when it is obvious to them that their administrations are no longer needed.

The national income being very large indeed, income and like taxes upon production will bring in an enormous revenue. After deflation of the National Debt, these taxes will have to be reduced and finally abolished; the people will begin to see very clearly their true incidence.

As the epoch of peace and prosperity advances, nation shall not rise up against nation any more. The huge cost of the upkeep of the Army and Navy, borne by productive industry, will gradually subside as these institutions become redundant. Free men will laugh as they think of the childish panics of the Dark Ages of the receding Old World of superstition.

The public rent of land, which is not really a tax, long before this consummation throughout the world, will have become sufficient to meet decreased public expenditure in leading nations. There will be a concentration of the Common Fund devoted to those legitimate public enterprises of the municipalities and local councils which we have called circulatory, and which will be increasingly necessary for our towns and villages, due to the vigorous intercourse awakened by the New Civilisation.

When Justice reigns, taxation will abolish itself. There will be firmly established the two principles of our Great Charter of Liberty:

"I. That all men have equal rights to the use and enjoyment of the elements provided by Nature.

"II. That each man has an exclusive right to the use and enjoyment of what is produced by his own labour." (Henry George.) 


\section{PRACTIGAL POLITICS v. IMPRAGTIGAL POLITICS}

\section{READER'S GUIDE}

IN Chapter XVIII we conclude, and in taking our leave of each other, contrast coercive policies with reasonable policies founded upon justice and mercy.

\section{The Headings are:}

The Survey-No One is without Influence-“ Practical" Politics-Killing no Murder ?-The Rule of Fear is the Will to Extinction-Cut-throat Empires are not Practical-The Folly of Imperialism-" I will not send American Boys to die in Mexico for Rich Men's Pocket-books "-Better a Devil you know than a Devil you do not know-Volcano " Controllers" - The Infinite Value of Human Life-The Manners of the Old World are the Manners of Slumdom-The War "Controllers" - "Vengeance is Mine, I will repay"-The Prospect offered by Impractical Politics-The Aftermath of War - The Broad Acres of the Earth have been narrowed - Race Problems-That they may receive their SightThe Seeds of Future Madness-Realities of War -The Real Defeatists are the Worshippers of the Brazen Ass-The Realities of Peace-The Super-volcano - "Morituri te saluant"-We are worshipping False Gods-Let us renounce It All. 
I am only one, but I am one :

I cannot do everything, but I can do something:

What I can do, that I ought to do:

What I ought to do, that, by the grace of God, I will do.

ANonymous.

A dumb man gets no land.-Proverb. 
CHAPTER XVIII

\section{PRAGTICAL POLITIGS v. IMPRAGTIGAL POLITIGS}

\section{The Survey.}

We have reached our destination. Like mountain climbers, we feel that on the way we have solved some mysteries and overcome difficulties, which, solved and overcome, seem to have shrunk in fearfulness.

Glancing behind us, we see far back the dark clouds and mists of superstition overhanging the path from which we have emerged into clear sunshine. We see before us the Road to Freedom, and beyond that the fascinating peaks of a new religion for mankind that can be scaled only from the plateau of the Promised Land, spread out in the distance far and wide awaiting husbandmen.

It is a land flowing with the milk of human kindness and the honey of a happiness now denied by man's inhumanity to himself. It is not for ascetics or voluptuaries, but for reborn men and women with sound minds in healthy bodies.

Its mental climate is bracing, suitable for the recovery of a population which has been kept closely confined in the Valley of the Shadow of Death, subjected to long servitude, enervated by exhausting pleasures or weakened by the feverish orgies of violence.

It is a land filled with the song of birds, the lowing of cattle, the humming of bees, and the joyous laughter of children, happy, strong and beautiful to behold. In such a land of thrilling activities and varied pursuits, chronic sadness and pressing anxiety to make both ends meet have no place, because there is free access to Nature's bounty.

Our Promised Land is not in the clouds, in a far-off country or on another planet, but under our very feet. Nevertheless, we may not enter except in spirit. To become a reality it must be shared by our fellows, whom we are about to rejoin in the Old World.

Remembering that we once had our vision dazzled by 
mirage, we shall not expect immediate acceptance of our new view-point. Some of us used to hug our chains or think that the way was too simple. The scepticism of others shall be met with calmness and with a simple exposition of economic truth. Many are prepared beforehand, and they will accept after careful investigation. These will become stable adherents, while too ready an acceptance may only indicate an equal readiness to accept any doctrine for a short season.

Habits of thought that have taken years to acquire cannot be exchanged immediately for new ones directed from a new point of view. Pressing may defeat its object.

The sufferers from an affliction which may be called mental sclerosis, and which arrests adaptability, may be condemned to see from a wrong point of view for the remainder of their lifetime. Their feelings need not be outraged upon the assumption that their hostility is due to excessive original sin. They will be found in every class of society, and nothing can be done in such cases.

There will be no effective opposition, because our proposal stands upon the firm ground of justice; but that is no reason why we should appear unsympathetic to narrow ideals and attempts to deal with intermediate problems. We must strive to show that they are part of one large problem which admits of a simple solution. Until justice is done the world will remain a battle-field, and ambulance work must go on.

The hardest to suffer are the mental invalids, who will querulously and irresponsibly inquire how we intend to obtain the Promised Land for them. We cannot; they must do something for themselves, and not be disappointed if it is not handed to them in the twinkling of an eye !

\section{No One is without Influence.}

No one is without influence. It is for some to blow the embers on the domestic hearth; for others to strive to light a beacon on the mountain-top; it is for others to teach in the wilderness of high places, while for others again to hold up a torch in the dark jungles of the underworld. The tide rises slowly at the commencement and then accelerates; so also the Good News will spread rapidly once the turn from fatalistic doctrine is made.

Knowledge of a great truth gives power to sincerity. 
"I respect the man who knows distinctly what he wishes. The greater part of all the mischief in the world arises from the fact that men do not sufficiently understand their own aims. They have undertaken to build a tower, and spend no more labour on the foundation than would be necessary to erect a hut." (Goethe.)

No political, industrial or religious body has an exclusive mission for the redemption of society, nor is some chosen government divinely appointed to reconstruct the world. It is not incumbent to change one's political colour, union or church, nor is it necessary to segregate egoistically in order to proclaim that the State is for Democracy, and not Democracy for the State.

No statesman can legislate for reform if the people do not sufficiently understand their own aims. Was not Turgot forced to retire into private life? The most despotic government cannot withstand the demand of a people that distinctly knows what it wishes. It was a Tory Government that abolished the Corn Laws in Great Britain. The despair of a reactionary government that has got itself into a situation from which there appears no escape may be the opportunity of an enlightened section of public opinion.

Inexperienced converts frequently say: "Why does not the Government do something for the enlightenment of the public?" The wise mother trains her children how to be independent of her care, though she grieve about it ; but it is not the characteristic of governmental masters to teach people how to do without them, because they represent human folly-until the people are wise.

Education precedes legislation, therefore educate.

It may be that the sluice-gates are not opened in time, and that the waters of blind rage, overwhelming Power and Might, rise and sweep into the abyss the arrangements made for the scientific exploitation of the masses, together with the puppets who are supposed to pilot the destinies of nations. After the deluge, the weathercock of the sword and the ballot-box having proved unreliable, appeal may be had to the Natural Law of Equity. Having tried everything else in vain, the Rule of the Land may be put into operation.

The Rule of the Land stands in direct sociological evolutionary progression. It is bound to come sooner or 


\section{FROM THE OLD TO THE NEW WORLD}

later, and during a crisis the still small voice of Justice may be heard. It may come like a thief in the night

\section{"Practical" Politics.}

The realisation of a great need is doubly screened when men do not know that they do not know distinctly what they wish. Hastening towards the latest mirage, they say : "We are practical people, and must take things as we find them. What you propose is very attractive, but it is not practical politics."

It was the "practical" politics of the "undertakers" of the sixteenth century, after they had partitioned England, to plough and harrow the soul of Ireland, into which Cromwell afterwards planted the thorn of Ulster. Ireland has since been an armed camp pitched upon a powder magazine. Irishmen do not really wish to kill Irishmen, and Englishmen would be overjoyed to see a real Irish settlement. All wish to respect each other's rights, but they do not understand their own aims distinctly. The real Home Rule for Ireland is the Rule of the Land.

"Popery" was the cry of the Protestant priests and rulers to rouse the " civilised " landless townsmen of England and the lowlands of Scotland to subjugate the "lawless savages " of the highlands during the reign of William III. The highlanders clung to the system of tribal possession of land, trusteeship being vested in the chief.

Chiefs were bribed to give up their independence with the offer of dominium, supported by the armed protection of the crown upon giving an oath of allegiance to the king. Refusal, or a show of refusal, was the signal for a war of extermination, in which "loyal" chiefs sought to extend their territory.

The massacre of Glencoe is a classic example of the atrocity committed by "practical" politicians. It was carried out by English soldiers, who had been quartered with all possible kindness for several days upon the poor people they afterwards ruthlessly butchered. "Your troops," wrote the younger Dalrymple to the commanding officer, " will destroy entirely the country of Lochaber, Lochiel's lands, Keppoch's, Glengarry's and Glencoe's. Your powers shall be large enough. I hope the soldiers will not trouble the Government with prisoners." 

lead.

It is always in this direction that impractical politics

During the recent Great War for the possession of Europe a "practical " politician, the ex-Kaiser Wilhelm of Germany, referring to Belgium, wrote to his ally, Francis Joseph of Austria: "My soul is rent, but everything must be put to fire and sword-men, women and children must be slaughtered."

\section{Killing no Murder?}

The "practical" politician is a serious and somewhat sentimental enthusiast, who thinks that violent action is the only policy worth while and that any problem can be solved by slaughter : a visionary, impatient of argument, he fears nothing-except to be laughed at! Conscious of being really ridiculous, he suspects that one day the worst may happen. Cultivating a fierce aspect, therefore, he glares savagely round to see that everyone is preserving a solemn countenance!

He will tell you that the military occupation of India, Egypt and Mesopotamia by Great Britain possibly does rest upon a series of fictions, but if left to themselves native races would fight and kill each other; besides, it would never do for white women and children to be there without protection.

Does it make the position safer for white women and children in India, or anywhere else, that an unhappy General Dyer, because the natives of Amritsar held a peaceable meeting to discuss grievances in their own country, took it upon himself to turn out armed men and shoot upon them there in the enclosure, from which it was almost impossible to escape ?

It may be that the meeting was being held in defiance of orders which he thought he had a right to give, and that feeling ran high because he had decreed that all natives should crawl instead of walk along the main street as a punishment for the wrong-doing of some unknown few; but is the murder of three hundred innocent men, women and children, who were defenceless, an act tending to the safety of the British Empire?

Yet the "practical" newspaper press said it was, and that it would save greater bloodshed in the future! 


\section{6 \\ FROM THE OLD TO THE NEW WORLD}

\section{The Rule of Fear is the Will to Extinction.}

"This I would say, standing as I do in view of God and eternity: I realise that patriotism is not enough. I must have no hatred or bitterness towards anyone." (Edith Cavell.)

The Mad Dog of Europe and his fellow "patriots" thought they were ensuring their safety by the sinking of the Lusitania and by the murders of Miss Cavell and Captain Fryatt. Imagining that the world could be conquered by frightfulness, the "baby-killers" shelled unprotected coastal towns and dropped aerial bombs upon English towns and villages. This "patriotism" brought about the end of the German Empire. Is the lesson not enough.?

No; the British militarists desire to reign in the place of the Prussian scarecrows. They deceive themselves, and seek to deceive others: "Military spirit is not militarism; .. Militarism is a disease, a form of megalomania; it is not British. . . The world has not reached a state where some other method of national education can be found equivalent to the qualities which a sound use of military training can bestow." $r$

Militarists are devoid of humour the world over !

After the Armistice, with the same lack of psychological verve as their late enemy, they bombed with aircraft open villages in India for the purpose of breaking up political meetings. It was afterwards, to their intense astonishment, that the Amritsar affair took place. A few more such incidents, and the British Empire will be as much a thing of the past as the short-lived German Empire.

\section{Cut-throat Empires are not Practical.}

With the engine scotched and steam blowing off at the safety-valve, it is certainly risky to remove weights from the lever, but it is dangerous to sit upon it. The visionary who does so is doomed in any case, and the inevitable explosion may destroy many innocent lives besides. The remedy is to set the engine free.

While injustice continues the withdrawal of troops from occupied regions may be risky ; but it is clear that anywhere permanent peace rests upon institutions that are just, and not upon methods of coercion. It is the same in every country-

- The Mission of the British Army, issued by the Ministry of Reconstruction. 
in India, in Ireland, in Russia, in Mexico, in Egypt, in the United States or in the United Kingdom. Militarism cannot overcome militarism.

\section{The Folly of Imperialism.}

Why are white women and children living in India? India, Persia and Egypt may be countries to trade with and visit, but they are not intended by Nature for the domicile of Europeans. White people are not happy living in these localities, apart from the dangerous environment they make for themselves by reason of imperialistic domination.

In the Middle East, in the Far East, as in the West, there is native misrule. There would not be more if Europeans did not lend military aid to native tyrants for tribute, as, for example, monopolistic concessions to leagues of traders and moneylenders, European Governments themselves not being above taking part in the illicit traffic. While the ignorant natives of Asia and Africa are sucked dry through native channels, the equally thoughtless natives of Europe suffer from indirect taxation imposed by private trusts and public monopolies, the octopus arms of which cover the globe. Spurious Socialism is a many-headed monster! Imperialism is its worst form!

Since the Armistice the taxpayer of Great Britain has been ruining the health of his sons by sending them to keep what is called "law and order" in Egypt, Palestine and Mesopotamia so that a few oil, cotton, flax and tobacco magnates may build up Big Businesses. He pays about forty million pounds in taxes per annum for the support of this bureaucratic and military system, which enables Big Business to operate upon the producer abroad and the consumer at home.

Does he visualise the reality when he admires the Government recruiting posters? "See the world, and get paid for doing it!" "Carrying democracy's message to the frontiers of civilisation!" is the American version. At the bayonet's point-what a message! Seek ye first the reign of free production, free exchange, and free men, and plentiful supplies of sugar, tea, coffee, rubber, oil, cotton, rock phosphate and copra, among other things, will be added unto you.

Europeans and Americans would not remain to perish in regions for which they are unfitted were they to annex each their own home-lands by the adoption of the Rule of 


\section{FROM THE OLD TO THE NEW WORLD}

the Land. In the profuse production that would ensue, free exchange with each other and with Eastern lands would be a matter of course. How long are we to continue picking each other's pockets?

Is it difficult to choose between practical and impractical politics?

\section{"I will not send American Boys to die in Mexico for Rich Men's Pocket-books." (President Wilson.)}

War is brewing in the Middle East for the control of the oil-fields. While British boys are sent to die in Turkey and Persia and taxpayers are being fleeced in the oil interests, there is a "strong" policy advocated by the "practical" politicians of the United States of America for intervention in Mexico.

Bandits of Mexico have robbed and murdered many fellowcountrymen, and also some venturesome citizens of the States. The Mexican President, Carranza, who denied the right of the syndicates to monopolise the oil land, and who made an honest attempt to form a stable government, has been murdered. $\mathrm{He}$ was condemned by the British and American oil trusts because his Government proposed to tax them according to the value of their concessions, which would have ended their power to charge outrageous prices to consumers for natural oil. By the same principle the other bandits would have disappeared also, because they were a product of alienation.

In Great Britain and the States the respective Governments confiscate the legitimate earnings of industry every day and no voice of protest is heard from the trusts; but when Carranza proposes to cease doing so, and instead to collect the annual value of the land, the hypocritic newspapers of New York and London, in the interests of "oil," stir up hatred of unthinking readers against him and pretend that the Mexicans encourage brigandage.

In the States and Great Britain foreign business undertakings are expected to abide by the laws of the country in which they operate. Why should the intruder oil syndicates of Mexico expect a special dispensation there ?

Let the remedy be what it may with regard to the irregular banditti of Mexico, it cannot be one necessarily 
entailing the sacrifice of innocent life, represented by the youth of the States and law-abiding Mexican men, women and children, the criminals in all probability escaping scot-free.

\section{Better a Devil you know than a Devil you do not know}

It is not clear that Mexicans wish to protect their home variety of bandit, but assuming that they do, they are not peculiar in this. The Germans protected their Kaiser and the other pirates. Britain and the States do the same, and resent foreign intervention. All nations fear a foreign master more than the indigenous tyrant or highwayman.

National feeling in this respect is very like that exhibited by the poor woman, the sight of whose bruised face moved the district visitor to ask pityingly: "Who did it ?" The proud answer was: "'Im as 'as a right to!" Wrongs are claimed and accepted as rights where there is vested ignorance.

\section{Volcano "Controllers."}

"We are in the hands of an organisation of crooks. They are politicians, generals, manufacturers of armaments and journalists. All of them are anxious for unlimited expenditure, and go on inventing scares to terrify the public and to terrify Ministers of the Crown." (Lord Welby in I9r4.) $)^{x}$

In Hawaii the simple islanders were in superstitious terror of the goddess Pélé of their great volcano Kilauea. It was the chief business of the high-priest and the priestess his sister to keep Pélé appeased with sacrifices. The power of these Volcano "Controllers," vested in the fear of the people, was so great that they had only to point to a man or woman and the unfortunate wretch was strangled by relations and friends.

Owing to communal custom there was a dearth of commodities, and a native might be killed by the priesthood for the sake of food and clothes not worth fifty cents. The temper of the high-priest was so fierce that no one dared tread on his shadow.

But strangers came to Hawaii who taught superior social custom and credence. At length the natives came

I See How Diplomats Make War, by Francis Neilson, published by B. W. Huebsch, New York. 


\section{FROM THE OLD TO THE NEW WORLD}

to realise that their belief in Pélé was due to seeing things falsely. In great numbers the islanders forsook their allegiance to the cruel goddess until none believed any longer. Even the high-priest admitted: "I have been deceived; I have deceived others. I have lived in darkness, and did not know the true God. I worshipped what was no god. I renounce it all."

There were no more victims for Pélé.

\section{The Infinite Value of Human Life.}

Ask any normal father what value he puts upon the life of his son. He would not have him killed or maimed for any money-not if he were to be compensated with an amount equal to the whole British National Debt. Let him be asked if he would, assuming it to be within his power, sacrifice the son of another father for this amount. $\mathrm{He}$ will give a reply in the negative.

Human nature is the same all the world over. Why then do we in the Old World sacrifice our sons, and the sons of others, in a wild-cat expedition to recover money lent to the Russians in the shape of munitions of war for the destruction of German militarism? Or it may be some shady imperialistic scheme of conquest in a remote country, the gains of which are not only problematical, but actually less than nothing, the losses beyond computation?

Is it practical to hold human life, which is infinitely valuable, cheaper than nothing? "Yes," say the Visionaries of the Thieves' Kitchen, " because the remote country requires development in the interests of its inhabitants. There is oil there."

The visionaries imagine it is profitable to exchange blood for oil!

\section{The Manners of the Old World are the Manners of Slumdom.}

In the Old World of constricted opportunity due to superstition and of restricted production due to rule-ofthumb taxation, the table of our daily lives suffers from interminable shortage, not merely in the three great requisites but of everything that is necessary for human happiness.

Where life is empty and miserable as though we were in a beleaguered city, is it not our experience that appetite 
is stimulated to excess or nauseated by disgust ? Instead of desires in the great nutritive and reproductive kingdoms tending to happiness, it requires constant effort on the part of the individual to escape from despair. There are two opposite tendencies, both of which in varying degree may alternate violently in the same individual. On the one hand appetites are aberrated into feverish cravings that cannot be contained, and on the other there is the reptilian apathy of a living death.

The national table is surrounded by a hysterical multitude of ill-bred persons or of cold-blooded degenerates, jostling, scrambling and crawling, seeking to dominate and conspire. Parties and factions of hero-worshippers gyrate in perplexed circles, deluding themselves that they are indispensable to national progress. Opposing political combinations fail to see that their real interests are identical. Churches unable to understand their own aims call "Lord, Lord!" but contend for the right of way to heaven, obscuring the truth that the kingdom of heaven is within us when we respect the rights of others as we respect our own. Robbery cannot be overcome by robbery.

Instead of free and willing exchange between generously laden national tables there is suspicion, jealousy and bad temper. Each starving nation is a robber or a mendicant, and fails to perceive that its misfortunes are in the main due to its foolish institutions. Each blames the other in some way, as, for example, holding up raw materials, "dumping" finished goods, tariffs, taking over too much of the White Man's Burden or "Bolshevism," all of which offences manifestly hurt the offending nations themselves infinitely more than anyone else.

Honesty is the best policy for the individual, though associated with unscrupulous companions. Similarly, justice is the best policy for the individual nation, though the surrounding nations are slave-States. But each nation of the Old World is myopic, and fancies that free trade, for example, is only expedient when the whole world is free-trade.

It is thought more "practical" to retaliate and to get " even" by self-punishment. Not knowing distinctly what they wish, their remarkable "success" in this "practical" policy distresses them when they realise that 


\section{FROM THE OLD TO THE NEW WORID}

they do not achieve their real aims. But they each blame not themselves, but their neighbours, or they blame everything but the right thing.

Consequently nations are filled with consuming hatred and snobbery. Fixed by their superstition like the rats upon the varnished board, $x$ the smallest movement is enough to set them savagely at each other's throats.

\section{The War "Controllers."}

The nations of the Old World, worshipping false gods, are living upon the slopes of a volcano. So dreadful is the calamitous mental atmosphere that it is considered an impiety to suggest that, unlike the eruptions of Kilauea, war and civil commotion are within the scope of each nation's choice, and that it is possible to have real peace with universal disarmament by the adoption of free production and free exchange, men thereby securing what they are continually fighting for, viz. freedom.

It is vainly imagined that freedom can be obtained by violence, and that the fundamental injustice which throttles wealth production at the source, rendering intertrading a dangerous proceeding, may at the same time be retained. Hence it is that the volcano is always in a state of activity, with periodic eruptions of extreme violence.

The diplomats, " who lie for their country's good," unlike the priests of Pélé, do have some influence upon the activities of their volcanic god. By making misunderstandings more completely misunderstood through their secret diplomacy, they can so conjure a situation that many minor potentialities combine into one grand explosion when the match is applied.

The well-intentioned busybodies of slumdom intervene in the domestic affairs of the house divided against itself across the way, and thereby produce a street riot. With a power vested in the dread of the ignorant masses, the war " controllers" are as unfortunate in producing the very effect they set themselves out to avoid when they intervene in an affair of "honour." They produce a world war.

\section{"Vengeance is Mine, I will repay."}

The war "controllers" in their other rôle as "controllers" of peace and goodwill are not any happier. The

I See Chapter V. 
"Big Five," in their attempt to take an eye for an eye and a tooth for a tooth, cut as unheroic a figure as the extinct volcano " controllers " of Germany. The impractical folly of the Peace of Versailles is scorned by the justice of Nature.

The "dreamers" have been vindicated who asserted that in hurting others we hurt ourselves. Since the Armistice, largely owing to the wreck of Europe, continued by the blockade, the cost of living in Great Britain has advanced by leaps and bounds. It has been advanced yet further since the "Iron Hand" policy in Ireland impeded production and choked off the exports of food-stuffs to industrial England, where 400,000 acres more of arable land have fallen out of cultivation. Meanwhile, the Supreme Council, which could not afford to be laughed at, has seen to it that the war-god was appeased with sacrifice.

The taxation per head of population in the United Kingdom was in I920 more than any other country in the world, not excluding defeated Germany. Twenty little wars were in progress.

\section{The Prospect offered by Impractical Politics.}

The soldiers, wise in their generation, have no faith in Leagues of Nations or in the witchcraft of diplomacy.

"Our peace must be a peace of victors, and not of vanquished," said Marshal Foch in an interview (April I9I9, Daily Mail). The Marshal argued that the French should have a barrier at the Rhine against Germany instead of one only by the Saar Valley. "It is our only safety, and the only safety of the British. We must have a barrier. We must double-lock the door. Democracies like ours, which are never aggressive, must have strong natural military frontiers. Remember that those seventy millions of Germans will always be a menace to us. Do not trust the appearances of the moment. They are people both envious and warlike. Their natural characteristics have not changed in four years. Fifty years hence they will be what they are to-day.

"What was it saved the Allies at the beginning of the war? Russia. Well, on whose side will Russia be in the future? With us or with the Germans? I will show you a map."

The Marshal did not believe that wars had ceased upon earth, and he wanted security when the armies of Great 


\section{FROM THE OLD TO THE NEW WORLD}

Britain, the United States of America, Australasia and Canada were far away. "Bolshevism," said he, "is a disease which attacks conquered countries. Conquering countries like our own will remain free from it."

During the short period since the interview there have been several aggressive French and British expeditions into Germany and Russia. The Allied democracies have aided the megalomaniacs Koltchak, Denikin, K.C.B., Yudenitch, Petlura and Wrangel. The militaristic Poles have been supplied with ammunition for their disastrous attack upon Soviet Russia, and would have had more, but for the gallant refusal of the Thames dockers to load the Jolly George. The Japanese have been encouraged to occupy Siberia. Meanwhile, the United States having withdrawn, Britain, France and Italy have been engaged in a sordid scramble of private profiteering and national aggrandisement, in which each bought the other off by the sacrifice of something that belonged to none of them.

After an unsavoury controversy as to who won the war, there has been an unseemly dispute as to who should pay for it. Rent has even been claimed by the French Government from her Allies for occupied trenches. Property has everywhere been put in the place of humanity. There is no real friendship anywhere in consequence.

The people of Europe had hoped for a Peace of Justice and Mercy, which would lead them out of the misery in which they were plunged, but they have been given a Peace of Vengeance which has led them into despair. Innocent children have been condemned by the post-war blockade to the slow death of consumption, rickets and foul disease. They have been made to suffer for the sins of the guilty warlords who were given sanctuary. The soldiers, who hated war and were driven to the shambles, have been handed over to the merciless profiteers. In German cities Marshal Foch has placed black troops of occupation, and in famishing Vienna the mothers say to their children: "What terrible misfortunes the English have brought upon the world!"

The fears of Marshal Foch are well founded. Everything possible has been done to bring about that combination of circumstances suitable for the birth of a new opposing militarism in Central Europe. He is mistaken, however, 
in assuming that "Bolshevism" is a disease which attacks conquered countries only.

Was France a conquered country when attacked by "Bolshevism" about one hundred and twenty years ago ? Was there not an attempt made then to double-lock the door against the people of the Revolution, who were supposed to be " both envious and warlike" ? Is it not remarkable that what saved the "Allies" on that occasion from the "Huns" of the militarist Napoleon was-Russia ?

There is no safety in the fences of the Supreme Council, or in Marshal Foch's barrier for France, Britain or anyone. The hope of Europe is that Russia does not become a country of landed proprietors, but leads the way in the adoption of the Rule of the Land.

The prospect offered by the impractical politicians is black indeed. "The magnitude of the next war, if no means are found to prevent it, will be far greater than we have yet experienced or imagined. It will be a war of continents - of Asia against Europe-if the relations between States or combinations of States are to be carried on lines similar to those which have prevailed in the past.

"Every human device has been tried to stave off war in the past. Treaties, alliances, balance of power, diplomacy have all failed. It is not to be expected that the nations of Europe or of the world will attain within measurable time the degree of political identity which unites the races of Great Britain; yet it is not fantastic to believe that along that road is the world peace. Perennial peace for the world can only be won by the levelling up of nations." (Sir Douglas Haig at Edinburgh, I9I9.)

But Sir Douglas, now Lord Haig, did not know distinctly what it was he wished, consequently he advocated more "preparedness." In the United States of America they are preparing a great Navy, and the newspapers say it is "the most dangerous competitor with which British sea-power-has ever been confronted."

This is not the "levelling-up" that will make for perennial peace between the nations.

\section{The Aftermath of War.}

Since the Armistice the atrocities that provide copy for the sensation Press and the cases of shattered affections 


\section{FROM THE OLD TO THE NEW WORLD}

that engage the time of the law courts register the amplitude of the wave of crime from the explosive eruption of wholesale murder, pillage, theft, fraud, forgery, treachery, incendiarism and immorality that we call the Great War. Life has become more complex and wearisome, and disillusionment reigns in the place of war-time buoyancy. A hysterical anxiety for the future alternates with a recklessness of consequences.

In a case (January I920) wherein a woman had died as the result of an illegal operation, Mr. Justice Darling, who made no reference to the economic cause underlying such unnatural behaviour, said that we were committing race suicide. With so many enemies knocking at the gates of the British Empire more children were required.

To undertake the upbringing of children destined to be chair a canon is not an encouraging prospect to give to shabby respectability struggling to meet the rising cost of efficient education in the stampede of beggar-my-neighbour! It is, however, all the prospect that impractical politics has to offer.

The London Daily Mail (February I920) drew attention in an editorial to the preponderance of one million females over males in the population of the United Kingdom, and this was said to be an inevitable accompaniment of a high civilisation such as ours. The merits of polygamy and female infanticide were solemnly debated in view of the national urgency for male children to defend the Empire.

Have the impractical spendthrifts in human life at last reached the climax that was attained by the buried Eastern civilisations? Our civilisation must be "high" indeed!

\section{The Broad Acres of the Earth have been narrowed.}

In the United Kingdom the cities, villages, public parks, small gardens, unoccupied town lots, docks, railways and common roads only cover I $_{5}$ per cent. of the area of the country. Apart from this portion, there are five acres of all kinds of land available per average family. The allotmentholders showed with regard to food what could be done even on one-twentieth part of an acre, and the shortage in houses and other things could be repaired in a similar direct manner-that is, by the application of labour to land.

Although the population is probably less than before the war, soldiers returned from "fighting to defend their 
lives, their liberties, their homes and their families " cannot find employment. The narrowed acres have further shrunk during their absence, due to the traffic in land, and the soldiers are invited to emigrate overseas and there to find new homes. But the "land sharks" are lying in wait for them there also.

What superficial thinkers do not realise is that it is not merely a question of how much land is necessary for the support of the population. So long as there is a negotiable value in sites the evil will appear and get progressively worse, no matter how thinly populated the country may be. The soil of a given country will support in comfort only a free people.

In Ontario, where there are 480 acres of land per average family, ex-service men are unable to find employment and standing room. It is proposed by the Government of the province to assist them out further west to Saskatchewan, where there are I, 800 acres per average family of six persons.

It is of course whispered confidentially by the impractical politicians, who lately in loud speeches extolled the brave soldiers and the virtues of Army discipline, that the men are demoralised by Army life and will not now fit neatly into the narrow niches of pre-war slavery!

\section{Race Problems.}

In the competition of "do without," Eastern races like the Japanese by long practice have succeeded in doing without more than white settlers like the Australians and Californians, who are nevertheless experts in doing without children.

Almost every other person one meets in California is a land-agent, whose function it is to see that no liberties are taken with Californian soil, and they are screaming because the Japanese, squeezed out of their own country, are answering the call of the idle acres.

In Australia they have also arrested the natural growth of white population through their superstition, and in their small numbers they fear the settlement of the yellow man in the northern territories, where the climate is unsuitable for the white man.

The solution to the so-called race problems is everywhere the same. It is to break down the barriers to the 


\section{FROM THE OLD TO THE NEW WORLD}

broad acres by means of the practical Rule of the Land. Then the white man will multiply exceedingly and replenish the earth where it is intended by Nature he shall. He will then welcome the presence of the yellow man, allowed to expand into adjacent situations which he only is adapted to fill.

But there is neither East nor West, Border, nor Breed, nor Birth, When two strong men stand face to face, tho' they come from the ends of the Earth.

\section{That they may receive their Sight.}

The impractical politicians, when they wish to appear profound, talk of the "blind forces of Nature." When they put forward "Birth Control" as a remedy for the evils that beset us, they speak savagely of "Nature's curse of fecundity" or of "the blind and futile fecundity of Nature."

If Nature were blind, we, who are her children, should never see. But Nature is not blind; it is we who have not yet received our sight. Men and women must be blind who speak in one moment of " an all-seeing God," or of the " unerring vision and love of the Eternal Disposer of events," and immediately afterwards talk of Nature as "blind."

\section{The Seeds of Future Madness.}

In consequence of our blindness the wide world has been so narrowed that in the congested thoroughfares of human intercourse it is not possible to give way to each other. The strongest men in the hostile environment may experience unwonted feelings of hatred towards their fellows. They turn them aside, for hatred is the seed of future madness.

Apart from industrial and domestic misunderstandings, the economic consequences of the so-called Peace, carried along upon the insane momentum of the War, have promoted cleavages between the friendliest Allies. Between Canadians and Americans across the border there are unreasonable differences and heartburnings over their respective burnt-offerings in the recent Great Sacrifice.

Between the States and England frivolous difficulties have arisen about finance, the exchange and the League of Nations-a general hotch-potch hotly flavoured by the irritating intrusion of the Irish question.

New York newspapers have resumed their former amusement of twisting the British lion's tail, and in London an 
obscure periodical has placarded the hoardings with ravings such as "What is America's Game?" and "America's Insult to Our Dead."

It is all so perplexing to the student of affairs who has not yet learnt that the phenomena of life, of mind and of social relationships are as much the result of cause and effect as are physical phenomena.

\section{Realities of War.}

If war could be ended merely by a realisation of its horrors, it would have ceased long ago. Like poverty, vice and pestilence, war is a component of superstition, and it, like them, will continue until the simplicity of scientific religion dissolves the complexity of rule-of-thumb guesswork,

From the point of view of progress the painfulness of consequences arising from error is good. It is God's or Nature's fiat, "Children, not this way!" It is well, therefore, that writers like Sir Philip Gibbs should reveal to those who have not had actual experience how terrible war is. It is well because, seeing that the consequences of error are so painful, men's minds may be turned from error to search for justice.

But just as unimaginative people gloss over the social crime of poverty and vice, so they seek to deceive themselves and others about the nature of war. The Great War, far from being a war to end war, has only given the elderly preachers of death, who lamented that the war had not been carried on long enough, a new bloodstained text. The silent sacrifice of youth in the shambles of Flanders made no appeal to the colour-blind cynic who earns a living by filling the newspapers with false views.

The following example is from the Nere York Times newspaper (March I920):

"Germany not 'War' Responsible.-Unlike Barbusse and other defeatists, Mr. Gibbs waited till the war was over before he allowed himself to write in the strain of Now It Can Be Told. For that he is to be commended, but his justification for writing in that strain at all is more than dubious. Of what he set down as an observer the accuracy need not be questioned, but his conclusion, which he asks his readers to accept-the conclusion that 'This is war !'-can be and should be denied. 


\section{FROM THE OLD TO THE NEW WORLD}

" The true conclusion from his facts is different- ' this' is what must happen when unprepared peoples are suddenly forced to defend their lives, their liberties, their homes and their families from the attack of a nation that has long been making ready for the greatest and most ruthless of all robber raids. It is not 'war' that should horrify Mr. Gibbs, but the German Government, for that Government was responsible for every one of the horrors that excited his righteous indignation....

"And what alternative does Mr. Gibbs propose to the horrors he calls war? Submission to domination when next the same or another brigand race starts out to conquer the world ?"

Our valiant critic would appear to be labouring under the following threadworn delusions : that militarism, or desire to dominate, is peculiar to the Germans; that Germany alone was responsible for the war; that a nation or nations, by copying Germany's example in " making ready," can effect security; that a nation can create a great military machine without becoming militaristic and behaving aggressively.

Philip Gibbs did not set himself out to show how war could be avoided, but he did propose an alternative. He said, "Let us have Peace." Peace with submission to domination is of course an anomaly. Such a thing never has existed and never will exist, and that is why there is continual strife in the world. At the present day every nation is a subject nation, either to indigenous or to intrusive masters, and one category can be as dominant as the other. In the existing circumstances all Governments are compelled to act like brigands.

\section{The Real Defeatists are the Worshippers of the Brazen Ass.}

No nation being free (though it protests that it " never, never will be slaves"), all nations are at war within and without. Any nation, therefore, is in danger of defeat and subjugation to some rival gang. But there is no permanency.

In the struggle for supremacy, which has no finality, the new gang in their turn are doomed to be overcome by fresh rivals. There cannot be peace upon the existing foundation. The real defeatists are they who accept things as they are and put their trust in organised violence. 


\section{The Realities of Peace.}

The basis of Peace is Justice, and no nation that has not annexed its own country, thus becoming a Sovereign People, may hope to find peace. So soon as a nation respects its own rights it begins to respect the rights of others.

Nations, like individuals, profit by example that is permanently advantageous. It is in this direction only that the consummation of a Brotherhood of Nations lies. First there must be a reign of Justice, which will bring about a profusion of Goods. Then will follow a reign of Benevolence.

Landless nations, oppressed with an increasing burden of Ills, are filled with envy, hatred and malice. Each is jealous of the other and possesses a consuming desire to dominate neighbours. Leagues of such nations inevitably become leagues of pickpockets, liars, bandits and cut-throats.

\section{The Super-volcano.}

Until this Central Truth is recognised, earnest men, not sufficiently understanding their own aims, will go on paving the way to greater mischief.

Addressing the members of Lloyd's on the subject of the League of Nations (July I920), Lord Robert Cecil said: "Many people still believed in the doctrine that the best way to ensure peace was to prepare for war. The late war was a final condemnation of that policy, for at no period of the world's history had the nations of the world been prepared so elaborately for war. Others thought that safety might be sought in an alliance so strong that none would be able to attack it. The history of the world had strewn the ground thick with the fragments of such alliances."

After his lordship's speech, an unintelligent MajorGeneral, late G.H.Q., unconsciously withdrew the lamb's clothing that covered a lion's cub by saying, "The League of Nations was providing the same businesslike machinery for peace as the Versailles Council had done during the war! "

Lord Robert's honest soul is in the clouds, and while he sees up there an incoherent Ideal that is not a Super-State, he does not realise that his friends below are busily engaged in constructing " businesslike machinery to enforce universal peace."

Verily, the poseurs of the League of Nations have under- 


\section{FROM THE OLD TO THE NEW WORLD}

taken to build a tower reaching unto heaven, and they have bestowed no more attention to the foundation than they would for the erection of a hut. Instead, they are acting upon the assumption that " peace, goodwill, justice and the protection of the weak against the strong " can be found in the provision of leagued Power and Might so great that none would be able to withstand the alliance.

The protection of the weak against the strong has ever been the declared intention of such projects. Every form of oppression that we suffer from has had its origin in the creation of businesslike machinery ostensibly for the protection of widows, orphans, sick, poor, working classes and small nationalities. Yet how true it is that all that is necessary for our safety and welfare is to establish institutions affording everyone equal opportunity to life, liberty and the pursuit of happiness.

That the visionaries of the League of Nations stipulate "sanctions," the use of the instrument of blockade and other forms of organised violence to enforce covenants, is an unconscious admission of failure to understand the meaning of justice. As Lord Robert himself points out, history teaches that peace and goodwill have never been established in this way. Reconstruction, therefore, upon such a basis is doomed to disaster.

Their unfinished structure has already given ominous warnings of impending collapse. Quite early in the course of its construction President Wilson, the head architect, was injured by flying fragments of masonry. In his absence a horde of new designers have made elaborate attempts to ensure the stability of the building. The effect of their bolstering has simply been to overweight the treacherous foundation.

But they do not see the approaching crisis due to their retention of a basis that has shown itself, in its culminating effects, to be fundamentally and hopelessly defective. They say, "We are practical men. Application and industry, with reconciliation to things as they are, is better than to seek a new Utopia."

It is thus, with wise-sounding phrases, "practical" men drift from bad to worse policies and final disaster.

Not sufficiently understanding their own aims, the advocates for a militant League of Nations, to their intense bewilderment, are finding themselves being drawn into the 
centre of a new volcanic formation. Around them on every side the participant nations are making ready for the time when the League shall split asunder upon its shaky foundation.

Since the dawn of civilisation there never was such " making ready." Upon the land there are guns capable of throwing shells one hundred miles into crowded cities, and crawling tanks that make the land unsafe for democracy. The sea is infested with the most modern craft for unrestricted warfare. There are powerful bombing aeroplanes for the air that can operate six hundred miles from their base. Great strides have been made in the preparation and use of deadly poison gas and high explosives.

The League of Nations upon the present foundation is a potential super-volcano of a new militarism. It can only exist for a season as an additional weight to the safetyvalve. The inevitable explosion will take place when the pressure within enslaved Society mounts beyond the limit of forbearance under wrong.

\section{"Morituri te saluant."}

Even now the seams open in many directions, and small craters splutter here and there. The earth trembles with warnings of greater evils to come. The atmosphere of national and international relations is clouded with gloomy portents. From past experience we know that the next great suppuration upon the fabric of Society will surpass any former eruptions.

Then shall we hear again the war-priests chant their hymns of hate, marching in procession under banners inscribed with such words as Liberty, Christianity and Civilisation. On munition work men and women will exchange their souls for thirty pieces of silver. The spellbound youth of the nations will salute "the bald-headed vultures with spectacles on," and will deliver themselves for sacrifice upon the Altar of Patriodium, from which fresh rivers of blood will flow.

The prison walls will close further in upon us in consequence of this physical and moral violence.

\section{We are worshipping False Gods.}

Governments and Leagues of Nations do not really control these phenomena, any more than the child in the railway 


\section{FRON THE OLD TO THE NEW WORLD}

carriage controls the movements of the train by pulling at the window strap.

Like the individuals composing them, States are subject to Natural Law, or to what we sometimes call the Will of God. Their ordinances must be in accordance with the Natural Law of Equity or they will bring about mischief. In acting unscientifically, by attempting to establish " discipline-iron discipline for all," which is contrary to the Discipline of God or Nature, they resist the march of civilisation, and Society struggles violently to free itself.

Since governments, like clocks, go from the motion men give them, freedom cannot be won by fighting governments, nor by governments fighting each other. The destinies of mankind, though we forget or be unaware of the fact, are shaped not by man-made discipline, but by the Discipline of God. "Call no man master upon earth, for One is your Master, the Father which is in heaven, and all ye are brethren."

Are we to continue worshipping false gods, dying in a Fools' Paradise?

\section{Let us renounce It All.}

Seeing falsely, men attempt to supplant the Will of God by impractical politics. Owing to their omission to put into operation the Rule of the Land, which is fundamentally necessary to modern conditions of life, and which is in accordance with Natural Law, communities, especially forward communities, are afflicted with terrible social evils!

Natural Freedom is a Law of Necessity which may only be preserved by conforming to the Golden Rule of Equal Rights and Equal Duties. Practical politics lie in this direction alone. Let us turn our backs upon impractical politics. Let us obey and live.

$$
* \quad * \quad * \quad * \quad * \quad *
$$

So when the world is asleep, and there seems no hope of her waking Out of some long bad dream that makes her mutter and moan, Suddenly, all men rise to the sound of fetters breaking, And everyone smiles at his neighbour, and tells him his soul is his own.

KIPLING: The Dawn Wind. 



\section{DAY USE \\ RETURN TO DESK FROM WHICH BORROWED \\ LOAN DEPT.}

This book is due on the last date stamped below, or on the date to which renewed.

Renewed books are subject to immediate recall.

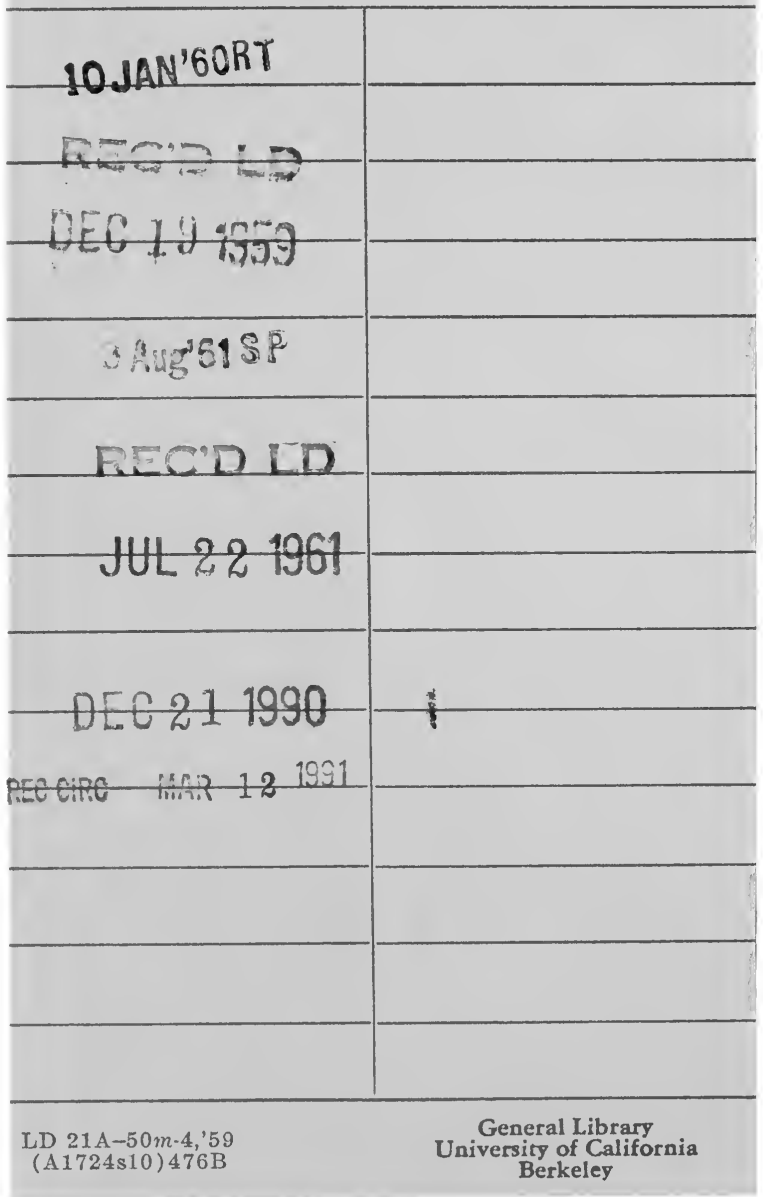




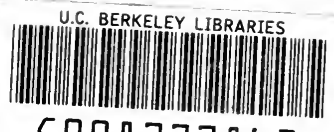

C008773863

6
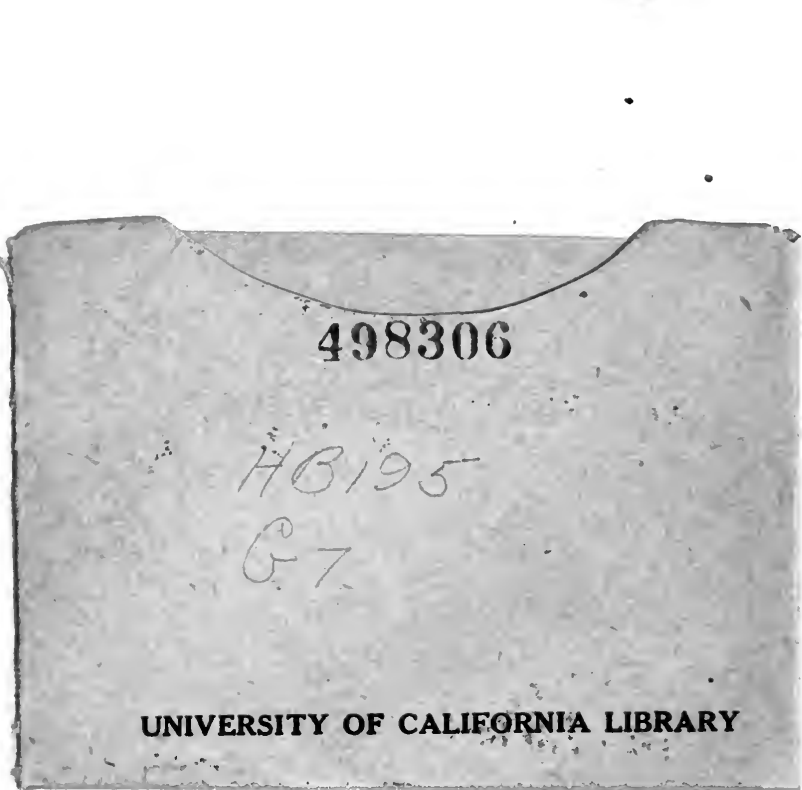

$\cdots$ 


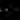

